\title{
Expedition 335 summary ${ }^{1}$
}

\author{
Expedition 335 Scientists $^{2}$
}

\section{Chapter contents}

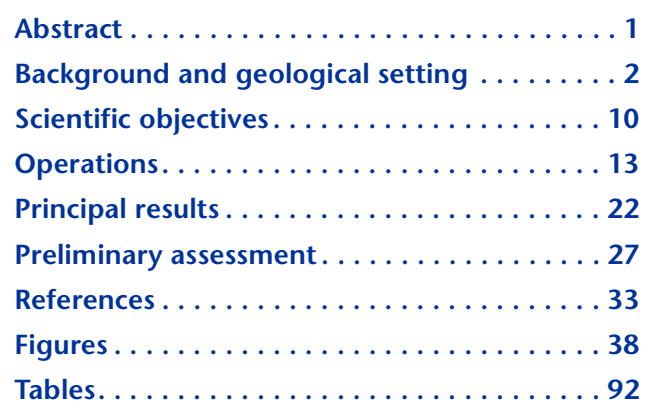

${ }^{1}$ Expedition 335 Scientists, 2012. Expedition 335 summary. In Teagle, D.A.H., Ildefonse, B., Blum, P., and the Expedition 335 Scientists, Proc. IODP, 335 Tokyo (Integrated Ocean Drilling Program Management International, Inc.). doi:10.2204/iodp.proc.335.101.2012

'Expedition 335 Scientists' addresses.

\section{Abstract}

The Superfast Spreading Crust campaign, echoing long-standing ocean lithosphere community endeavors, was designed to understand the formation, architecture, and evolution of ocean crust formed at fast spreading rates. Integrated Ocean Drilling Program (IODP) Expedition 335, "Superfast Spreading Rate Crust 4" (13 April-3 June 2011), was the fourth scientific drilling cruise of the Superfast Spreading Crust campaign to Ocean Drilling Program (ODP) Hole 1256D. The expedition aimed to deepen this basement reference site several hundred meters into the gabbroic rocks of intact lower oceanic crust to address the following fundamental scientific questions:

- Does the lower crust form by subsidence of a crystal mush from a high-level magma chamber (gabbro glacier), by intrusion of sills throughout the lower crust, or by some other mechanism? How does melt percolate through the lower crust, and what are the reactions and chemical evolution of magmas during migration?

- Is the plutonic crust cooled by conduction and/or hydrothermal circulation? What are the role and extent of deeply penetrating seawater-derived hydrothermal fluids in cooling the lower crust and the chemical exchanges between the ocean crust and the oceans?

- What are the relationships among the geological, geochemical, and geophysical structure of the crust and, in particular, the nature of the seismic Layer 2-3 transition?

- What is the magnetic contribution of the lower crust to marine magnetic anomalies?

Hole $1256 \mathrm{D}$ is located on $15 \mathrm{Ma}$ crust in the eastern equatorial Pacific Ocean $\left(6^{\circ} 44.163^{\prime} \mathrm{N}, 91^{\circ} 56.061^{\prime} \mathrm{W}\right)$. Oceanic crust that formed at a superfast spreading rate $(>200 \mathrm{~mm} / \mathrm{y})$ was specifically targeted to exploit the observed relationship between spreading rate and depth to axial low-velocity zones, thought to be magma chambers, seismically imaged at active mid-ocean ridges. This was a deliberate strategy to reduce the drilling distance to gabbroic rocks because thick sequences of lavas and dikes have proved difficult to penetrate in the past. Previous cruises to ODP Site 1256 (ODP Leg 206; IODP Expeditions 309 and 312) have achieved their legand expedition-specific objectives but not the overarching strategic goals of the Superfast Spreading Crust campaign to under- 
stand magmatic accretion at fast-spreading ocean ridges. However, the three previous cruises achieved the first complete sampling of intact upper oceanic crust, successfully drilled through $\sim 800 \mathrm{~m}$ of erupted lavas and thin ( $345 \mathrm{~m})$ sheeted dike complex, and sampled gabbros at $\sim 1157$ meters subbasement. The lowermost $100 \mathrm{~m}$ of the hole is a complex dike-plutonic transition zone that comprises two gabbro lenses intruded into strongly contact metamorphosed, granoblastically recrystallized sheeted dikes.

During Expedition 335, we reentered Hole 1256D more than 5 years after our last visit and encountered and overcame a number of significant engineering challenges, each unique but of natures not unexpected in a deep, uncased marine borehole into igneous rocks. The patient, persistent efforts of the rig floor teams cleared a major obstruction at $\sim 920$ meters below seafloor (mbsf) that initially prevented reentry into the hole to its full depth (1507 mbsf). The 920-960 mbsf interval was then cemented to stabilize the borehole wall. A short phase of coring deepened Hole 1256D 13 m before the C9 hard formation coring bit failed and was spectacularly ground to a smooth stump. A progressive, logical course of action was then undertaken to clear the bottom of the hole of metal junk from the failed coring bit, open up a short interval of undergauge hole, and remove a very large amount of drilling cuttings from the hole. This was successfully completed, and the hole is open to its full depth (1521.6 mbsf). The hole-cleaning phase was followed by wireline caliper and temperature measurements of the complete hole to assist with cementing operations to stabilize the lowermost $10 \mathrm{~m}$ of the hole and the problematic interval at 910-940 mbsf. These remedial efforts will facilitate reentry and coring on a future return to Hole 1256D.

In addition to the few cores drilled, the junk baskets deployed during the successive fishing runs to the bottom of the hole recovered a unique collection of samples, including large cobbles (as large as $5 \mathrm{~kg}$ ), angular rubble, and fine cuttings, principally of strongly to completely recrystallized granoblastic basalt, with minor gabbroic rocks and evolved plutonic rocks. The large blocks exhibit intrusive, structural, and textural relationships, along with overprinting and crosscutting hydrothermal alteration and metamorphic paragenetic sequences that hitherto have not been observed because of the small diameter of drill cores and the very low recovery of the granoblastic dikes cored so far. The high extent of metamorphic recrystallization exhibited by granoblastic basalt, combined with operational factors, provides strong evidence that most of this material comes from the lowermost reaches of Hole 1256D ( 1495 to $\sim 1522$ mbsf). Including the $\sim 60 \mathrm{~m}$ thick zone of granoblastic dikes that reside above the uppermost gabbros, the dike-gabbro transition zone at Site 1256 is $>170 \mathrm{~m}$ thick, of which $>100 \mathrm{~m}$ is recrystallized granoblastic basalt. When the textural and contact relationships exhibited by these samples are placed in the geological context of the Hole 1256D stratigraphy, a vision emerges of a complex, dynamic thermal boundary layer zone. This region of the crust between the principally hydrothermal domain of the upper crust and the intrusive magmatic domain of the lower crust is one of evolving geological conditions. An intimate coupling among temporally and spatially intercalated magmatic, hydrothermal, partial melting, intrusive, metamorphic, and retrograde processes is recorded in the recovered samples.

Expedition 335 left Hole 1256D after making only a very modest advance, and we have yet to recover the samples of cumulate gabbros required to test models of ocean ridge magmatic accretion and the intensity of hydrothermal cooling at depth. However, a remarkable sample suite of granoblastic basalt with minor gabbros, some of which intrude previously recrystallized dikes, was recovered and provides a detailed picture of a rarely sampled critical interval of the oceanic crust. Most importantly, the hole has been stabilized, cleared to its full depth, and is ready for deepening in the near future.

\section{Background and geological setting}

Drilling a deep hole through intact ocean crust formed at a fast spreading rate has been one of the prime motivations for scientific ocean drilling since its inception (Teagle and Ildefonse, 2011). Fastspreading ocean crust is targeted because geological and geophysical observations indicate that long distances of the ridge crests behave relatively uniformly. Consequently, we should be able to extrapolate the findings from a few deep penetrations to describe a significant portion of the Earth's surface ( 30\%). Only through the recovery of a significant section of cumulate gabbro underlying the dikes and erupted lavas will we be able to test competing models of magmatic accretion at fast-spreading mid-ocean ridges and evaluate the impact of these processes on the wider Earth system.

Integrated Ocean Drilling Program (IODP) Expedition 335 (13 April-3 June 2011) is the fourth scientific drilling cruise of the Superfast Spreading Crust campaign (Ocean Drilling Program [ODP] Proposal 522Full-2; D.S. Wilson et al., unpubl. data) to ODP Hole $1256 \mathrm{D}\left(6^{\circ} 44.163^{\prime} \mathrm{N}, 91^{\circ} 56.061^{\prime} \mathrm{W}\right)$ to deepen 
this ocean crust reference penetration a significant distance into cumulate gabbros. Hole $1256 \mathrm{D}$ is located on $15 \mathrm{Ma}$ crust in the eastern equatorial Pacific Ocean in oceanic basement that formed during a sustained episode of superfast ocean ridge spreading (>200 mm/y) (Wilson, 1996) (Figs. F1, F2). Ocean crust formed at a superfast spreading rate was deliberately targeted because there is strong evidence from mid-ocean-ridge seismic experiments that gabbros occur at shallower depths in intact ocean crust with higher spreading rates. Consequently, the often difficult-to-drill upper ocean crust should be relatively thin. Expedition 335 follows ODP Leg 206 in 2002 and IODP Expedition 309/312 in 2005 (Wilson, Teagle, Acton, et al., 2003; Teagle, Alt, Umino, Miyashita, Banerjee, Wilson, and the Expedition 309/ 312 Scientists, 2006), which prepared the first scientific borehole for deep drilling by installing a large reentry cone secured with almost $270 \mathrm{~m}$ of 16 inch casing through the $250 \mathrm{~m}$ thick sedimentary overburden and cemented into the uppermost basement (Fig. F2). Hole 1256D was then deepened through an $\sim 810 \mathrm{~m}$ thick sequence of lavas and a thin $(\sim 346 \mathrm{~m})$ sheeted dike complex, the lower $60 \mathrm{~m}$ of which is strongly contact metamorphosed to granoblastic textures. The first gabbroic rocks were encountered at 1407 meters below seafloor (mbsf), where the hole entered a complex dike-gabbro transition zone that includes two 20 to $50 \mathrm{~m}$ thick gabbro lenses intruded into granoblastic dikes. As of the end of Expedition 312 , Hole $1256 \mathrm{D}$ had a total depth of $1507.1 \mathrm{mbsf}$ and was open to its full depth. Hole 1256D was poised at a depth where, with a few hundred meters of penetration, cumulate gabbros should be recovered for the first time from in situ lower ocean crust. Such samples would reveal hitherto unavailable fundamental observations regarding the processes that form new crust at the mid-ocean ridges and the chemical exchanges between the crust, oceans, and mantle.

The scientific justifications for deep drilling of fastspreading ocean crust is further explored in the "Deep drilling of intact ocean crust: harnessing past lessons to inform future endeavors" chapter of this volume (Expedition 335 Scientists, 2012a). The specific tests of ocean crust accretion models planned for Expedition 335 are described below.

\section{Rationale for the Superfast Spreading Crust campaign and location of Site 1256}

The key to proposing the Superfast Spreading Crust campaign (Leg 206 and Expeditions 309/312 and 335 ) was to identify a style of crustal accretion where the extrusive lavas and dikes overlying the gabbros are predicted to be relatively thin, thus increasing the likelihood of penetrating through the complete upper crustal section in the fewest drilling days (ODP Proposal 522Full-2; D.S. Wilson et al., unpubl. data). Drilling lavas and dikes has proved problematic in past scientific ocean drilling, resulting in poor hole conditions, slow penetration rates, and low core recovery (Figs. F3, F4) (see the "Deep drilling of intact ocean crust: harnessing past lessons to inform future endeavors" chapter [Expedition 335 Scientists, 2012a]). The recognition that crust formed at a relatively fast spreading rate is a compelling target for deep drilling follows the observation that there is an inverse relationship between the depth to axial low-velocity zones imaged by seismic experiments, interpreted to be melt lenses, and spreading rate (Purdy et al., 1992) (Fig. F5). Since the Purdy et al. (1992) compilation, careful velocity analysis, summarized by Hooft et al. (1996), has refined the conversion from traveltime to depth, and data from additional sites have been collected (Carbotte et al., 1997). The fastest rate spreading centers surveyed with modern multichannel seismic (MCS) reflection, $\sim 140 \mathrm{~mm} / \mathrm{y}$ full rate at $14^{\circ}-18^{\circ} \mathrm{S}$ on the East Pacific Rise (EPR), show reflectors, interpreted as the axial melt lens, at depths from 940 to 1260 mbsf (Detrick et al., 1993; Kent et al., 1994; Hooft et al., 1994, 1996). At $9^{\circ}-16^{\circ} \mathrm{N}$ on the $\mathrm{EPR}$ where spreading rates are $80-110 \mathrm{~mm} / \mathrm{y}$, depths to the melt reflector are mostly 1350-1650 mbsf, where well determined (Kent et al., 1994; Hooft et al., 1996; Carbotte et al., 1997). The implication from reflection seismic studies of axial low-velocity zones is that crust formed at superfast spreading rates ( $>200 \mathrm{~mm} / \mathrm{y})$ should have a thin dike section and cumulate gabbros should occur at relatively shallow depths.

The theoretical basis for expecting an inverse relation between spreading rate and melt lens depth is fairly straightforward if one considers a gabbro glacier style of crustal formation (e.g., Henstock et al., 1993; Phipps Morgan and Chen, 1993; Quick and Denlinger, 1993). The latent heat released in crystallizing the gabbroic crust must be conducted through the lid of the melt lens to the base of the axial hydrothermal system, which then advects the heat to the ocean. The temperature contrast across the lid is governed by the properties of magma $\left(1100^{\circ}-1200^{\circ} \mathrm{C}\right)$ and thermodynamic properties of seawater $\left(350^{\circ}-\right.$ $450^{\circ} \mathrm{C}$ where circulating in large volumes) and will vary only slightly with spreading rate and ridge depth (e.g., Jupp and Schultz, 2000). The heat flux through the lid per unit ridge length will therefore be proportional to the width of the lens and inversely proportional to the lid thickness. For reasons that are not understood, seismic observations show uniform width of the melt lens, independent of 
spreading rate. With width and temperature contrast not varying, the extra heat supplied by more magma at faster spreading rates must be conducted through a thinner lid (dike layer) to maintain steady state (see Phipps Morgan and Chen [1993] for a more complete discussion). This analysis leads to the prediction that to reach cumulate gabbros in normal oceanic crust with minimal drilling, it is therefore best to target crust formed at the fastest possible spreading rates (Wilson et al., 2006).

A setting similar to the modern well-surveyed area at $14^{\circ}-18^{\circ} \mathrm{S}$ could be expected to reach gabbro at a depth of $\sim 1400 \mathrm{~m}$, based on $1100 \mathrm{~m}$ to the axial magma chamber reflector and subsequent burial by an additional $300 \mathrm{~m}$ of extrusives (Kent et al., 1994). At faster rates, depths could be hundreds of meters shallower. In contrast, seismic velocity inversions at the axes of the Juan de Fuca Ridge and Valu Fa Ridge, Lau Basin, are at depths of $\sim 3 \mathrm{~km}$ (Purdy et al., 1992), at intermediate spreading rates comparable to Deep Sea Drilling Project (DSDP)/ODP Site 504.

\section{Superfast spreading rate crust in the eastern equatorial Pacific Ocean}

The identification of magnetic anomalies formed at the southern end of the Pacific/Cocos plate boundary led to the recognition of crust formed at full spreading rates of $\sim 200-220 \mathrm{~mm} / \mathrm{y}$ from $\sim 20$ to 11 Ma (Wilson, 1996) (Fig. F1), 30\% to $40 \%$ faster than the fastest modern spreading rate. This episode of superfast spreading ended with a reorganization of plate motions at 10-11 Ma. The southern limit of crust formed at the superfast rates is the trace of the Cocos-Nazca-Pacific triple junction, as Nazca-Pacific and Cocos-Nazca spreading rates were not as fast. The older age limit of this spreading episode is hard to determine with the limited mapping and poor magnetic geometry of the Pacific plate, but it is at least $18 \mathrm{Ma}$. The northern limit of this province is entirely gradational, with rates dropping to $\sim 150$ $\mathrm{mm} / \mathrm{y}$ somewhat north of the Clipperton Fracture Zone.

The estimated depth to an axial melt lens for ocean crust formed at such a superfast spreading rate is $\sim 800-1000 \mathrm{~m}$. The anticipated depth to the gabbros for Site 1256 was $\sim 1100-1300 \mathrm{~m}$, allowing for a reasonable thickness $(\sim 300 \mathrm{~m})$ of near-axial lava flows (e.g., Hooft et al., 1996) (Table T1; see "Headline results from previous drilling at Site 1256: ODP Leg 206 and IODP Expedition 309/312"), making this region a compelling target for deep drilling to help us understand crustal accretion processes at midocean ridges.

\section{Geological setting of Site 1256}

Site 1256 lies in $3635 \mathrm{~m}$ of water in the Guatemala Basin $\left(6^{\circ} 44.2^{\prime} \mathrm{N} ; 91^{\circ} 56.1^{\prime} \mathrm{W}\right)$ on Cocos plate crust formed at $\sim 15 \mathrm{Ma}$ on the eastern flank of the EPR (Fig. F1). The depth of the site is close to that predicted from bathymetry models of plate cooling (e.g., Parsons and Sclater, 1977). The site sits near the magnetic Anomaly $5 \mathrm{Bn}-5 \mathrm{Br}$ transition in magnetic polarity and is centered in the zone that accreted at a superfast spreading rate $(\sim 200-220 \mathrm{~mm} / \mathrm{y}$ full rate) (Wilson, 1996). The site lies $\sim 1150 \mathrm{~km}$ east of the present crest of the EPR and $\sim 530 \mathrm{~km}$ north of the Cocos-Nazca spreading center. The trace of the Cocos-Nazca-Pacific triple junction passes $\sim 100 \mathrm{~km}$ to the southeast, with the elevated bathymetry of the Cocos Ridge recording the trail of the Galapagos plume farther to the southeast $(\sim 500 \mathrm{~km})$. The site formed on a ridge segment at least $400 \mathrm{~km}$ in length, $100 \mathrm{~km}$ north of the ridge-ridge-ridge triple junction between the Cocos, Pacific, and Nazca plates (Fig. F6). This location was formed near the Equator within the equatorial high-productivity zone and initially endured high sedimentation rates (>30 m/m.y.) (e.g., Farrell et al., 1995; Wilson, Teagle, Acton, et al., 2003). Sediment thickness in the region is between 200 and $300 \mathrm{~m}$ and is $250 \mathrm{~m}$ at Site 1256 (Wilson, Teagle, Acton, et al., 2003).

The Guatemala Basin has relatively subdued bathymetry, and the immediate surroundings of Site $1256(\sim 300 \mathrm{~km})$ are relatively unblemished by major seamount chains or large tectonic features high enough to penetrate the sediment cover $(\sim 200-300$ $\mathrm{m})$. Site 1256 was one of a number of sites approved by the ODP Site Survey panel (as Site GUATB-03C) (Fig. F7) for operations during Leg 206, and this specific location was selected from the regions surveyed to take advantage of faster upper crustal velocities, which correctly predicted the presence of massive basalt flows, and to avoid thrust faults that occur elsewhere in the region. The details of the $1999 \mathrm{Mau}$ rice Ewing site survey cruise operations are documented in Wilson, Teagle, Acton, et al. (2003) and Wilson et al. (2003).

Site 1256 has a seismic structure reminiscent of typical Pacific off-axis seafloor (Fig. F8). Upper Layer 2 velocities are $4.5-5 \mathrm{~km} / \mathrm{s}$, and the Layer 2-3 transition is between $\sim 1200$ and $1500 \mathrm{~m}$ subbasement (msb) (Fig. F9). The total crustal thickness at Site 1256 is estimated at $\sim 5-5.5 \mathrm{~km}$.

Site 1256 sits atop a region of smooth seafloor and basement topography (<10 m relief) (Fig. F7). Northeast of Site $1256(15-20 \mathrm{~km})$, a trail of $\sim 500 \mathrm{~m}$ high circular seamounts rises a few hundred meters above the sediment blanket. Using the site survey MCS 
data (Wilson et al., 2003), we have constructed a geological sketch map of the uppermost basement in the GUATB-03 survey region (Fig. F10). Elsewhere in the region, the top of basement shows a number of offsets along northwest-striking normal faults, and an abyssal hill relief of as much as $100 \mathrm{~m}$ is apparent in the southwest part of the area. Relief to the northeast is lower and less organized. In the northeastern sector of the GUATB-03 region, there is evidence for a basement thrust fault with a strike approximately orthogonal to the regional fabric (Wilson et al., 2003; Hallenborg et al., 2003). This feature dips gently to the northwest $\left(\sim 15^{\circ}\right)$ and is clearly discernible to a depth of $\sim 1.3 \mathrm{~km}$ on seismic Line EW9903-28 (Wilson et al., 2003), but the feature is less pronounced on seismic Line EW9903-27, indicating that the offset on the thrust decreases to the southwest.

Additional processing (A.J. Harding, unpubl. data) of ocean bottom hydrophone $(\mathrm{OBH})$ recordings indicates discernible variation in the average seismic velocity $(\sim 4.54-4.88 \mathrm{~km} / \mathrm{s})$ of the uppermost $(\sim 100 \mathrm{~m})$ basement and regional coherence in velocity variations (Fig. F10A). Two principal features are apparent: a 5 to $10 \mathrm{~km}$ wide zone of relatively high upper basement velocities $(>4.82 \mathrm{~km} / \mathrm{s})$ that can be traced $\sim 20 \mathrm{~km}$ to the edge of data coverage southeast of Site 1256 , and a relatively low velocity $(4.66-4.54 \mathrm{~km} / \mathrm{s})$ bull's-eye centered around the crossing point of seismic Lines EW9903-21 and EW9903-25.

The uppermost basement at Site 1256 is capped by a massive lava flow $>74 \mathrm{~m}$ thick (Fig. F2). This flow is relatively unfractured, with shipboard physical property measurements on discrete samples indicating $V_{\mathrm{P}}$ $>5.5 \mathrm{~km} / \mathrm{s}$ (Wilson, Teagle, Acton, et al., 2003). As such, it is likely that the area of relatively high uppermost basement seismic velocities represents the extent of the massive flow penetrated during Leg 206 in Holes 1256C and 1256D. Assuming an average thickness of $40 \mathrm{~m}$, this would conservatively suggest an eruption volume in excess of $3 \mathrm{~km}^{3}$, plausibly $>10$ $\mathrm{km}^{3}$. This is extremely large when compared to the size of mid-ocean-ridge axial low-velocity zones that are thought to be high-level melt lenses, which typically have volumes $\sim 0.05-0.15 \mathrm{~km}^{3}$ per kilometer of ridge axis and generally appear to be only partially molten (Singh et al., 1998).

Sheet flows $(<3 \mathrm{~m}$ thick) and massive flows $(>3 \mathrm{~m})$ make up most of the lava stratigraphy at Site 1256 (Fig. F2) (Teagle, Alt, Umino, Miyashita, Banerjee, Wilson, and the Expedition 309/312 Scientists, 2006), and such lava morphologies have been shown to dominate crust formed at fast spreading rates, away from segment tips (e.g., White et al., 2000, 2002). Subordinate pillow lavas are present in Hole 1256D (e.g., Tominaga et al., 2009), and because of the large number of fractures and pillow interstices, seismic velocities in these units are generally lower than more massive lava flows. We speculate that the bull's-eye of relatively low seismic velocities is a thick pile of dominantly pillowed lava flows.

At $15 \mathrm{Ma}$, Site 1256 is significantly older than Hole $504 \mathrm{~B}(\sim 6.9 \mathrm{Ma})$, and lower temperatures are predicted at mid-levels in the crust $\left(\sim 115^{\circ} \mathrm{C}\right.$ at 1500 $\mathrm{msb}$ ), so high borehole temperatures should not become an issue until a significant thickness of gabbro is penetrated (Fig. F11). Heat flow $\left(\sim 113 \mathrm{~mW} / \mathrm{m}^{2}\right.$ in Hole 1256C) is close to that predicted from cooling plate models, indicating minimal active hydrothermal circulation, as was confirmed by diffusive pore water profiles in the Site 1256 sedimentary overburden (Wilson, Teagle, Acton, et al., 2003).

The only serious drawback to the GUATB-03/Site 1256 area as a crustal reference section for fast spreading rates is its low original latitude. This means that the determination of magnetic polarity from azimuthally unoriented core samples is nearly impossible. In addition, the nearly north-south ridge orientation makes the magnetic inclination insensitive to structural tilting. Magnetic logging with either the General Purpose Inclinometry Tool (GPIT) fluxgates that form part of the Formation MicroScanner/Dipole Sonic Imager (FMS-sonic) tool string (or a separate magnetic tool with gyroscopic orientation) should be adequate for polarity determination and reorientation of recovered cores to the geographic reference frame.

\section{Headline results from previous drilling at Site 1256: ODP Leg 206 and IODP Expedition 309/312}

Hole $1256 \mathrm{D}$ in the eastern equatorial Pacific Ocean is the first basement borehole prepared with the infrastructure desirable for drilling a moderately deep hole into the oceanic crust $(\sim 1.5-2 \mathrm{~km})$. Following preliminary coring to document the sedimentary overburden at Site 1256, operations during Leg 206 installed in Hole $1256 \mathrm{D}$ a reentry cone supported by 20 inch casing and large-diameter (16 inch) casing all the way through the sediment cover and cemented $19 \mathrm{~m}$ into basement (Wilson, Teagle, Acton, et al., 2003). Armoring the sediment/basement boundary reduces erosion of the borehole walls at this weak point and assists in clearing drill cuttings from the hole. The cone and casing facilitate multiple reentries and help maintain hole stability. The large-diameter casing was deployed to protect against the situation where one or two more casing strings ( $133 / 8$ and $103 / 4$ inch) would be needed to stabilize the uppermost $\sim 100 \mathrm{~m}$ of oceanic basement 
during the initiation of Hole 1256D. It also allows the possibility that future expeditions could insert further casing into the hole to isolate unstable portions of the very uppermost basement or improve the borehole hydrodynamics for clearing cuttings from the hole (see "Operations"). Because of the occurrence of a very thick massive lava flow at the top of basement, casing was not necessary for securing the uppermost portion of the hole.

Volcanic sequences at Site 1256 comprise a sequence of massive flows and thinner sheet flows with subordinate pillow basalt, hyaloclastite, and breccia (Fig. F12). The uppermost crust at Site 1256 comprises a $\sim 100 \mathrm{~m}$ thick sequence of lava dominated by a single massive lava flow $>75 \mathrm{~m}$ thick, requiring at least this much seafloor relief to pond the lava. On modern fast-spreading ridges, such topography does not normally develop until 5-10 km from the axis (Macdonald et al., 1996). Although this lava flow cooled offaxis it may have originated at the ridge axis before flowing on to the ridge flanks, as is observed for very large lava flows on the modern ocean floor (Macdonald et al., 1989). The lava sequence immediately below includes sheet and massive flows and minor pillow flows. Subvertical, elongate flow-top fractures filled with quenched glass and hyaloclastite in these lavas indicate flow lobe inflation requiring cooling on a subhorizontal surface off-axis (Umino et al., 2000). From this shipboard evidence, a total thickness of $284 \mathrm{~m}$ of lava that flowed and cooled off-axis was estimated (Table T1). Sheet flows and massive lava flows erupted at the ridge axis make up the remaining extrusive section to 1004 mbsf, before a lithologic transition is marked by subvertical intrusive contacts and mineralized breccia. This contrasts slightly with the volcanic stratigraphy for Hole 1256D developed from analysis of wireline geophysical imaging (Tominaga et al., 2009; Tominaga and Umino, 2010) that suggests $<50 \%$ of the lava drilled crystallized within $1000 \mathrm{~m}$ of the axis but that the majority of the lava pile had formed within $3000 \mathrm{~m}$ of the ridge crest.

Rocks throughout pilot Hole $1256 \mathrm{C}$ and the uppermost parts of Hole 1256D exhibit dark gray background alteration where the rocks are slightly to moderately altered, olivine is replaced, and pore spaces are filled by saponite and minor pyrite as the result of low-temperature seawater interaction at relatively low cumulative seawater/rock ratios. Vein-related alteration is manifest as different-colored alteration halos along veins. Black halos contain celadonite and have been interpreted to result from the presence of upwelling distal low-temperature hydrothermal fluids enriched in iron, silica, and alkalis (Edmond et al., 1979; see summary in Alt and Teagle,
1999). The iron oxyhydroxide-rich brown mixed halos are later features that formed by circulation of oxidizing seawater. The brown halos have a similar origin and formed along fractures that were not bordered by previously formed black halos. This vein-related alteration occurs irregularly throughout Hole 1256D below the massive Unit 1 (lava pond) but is concentrated in zones of greater permeability and, consequently, increased fluid flow. The appearance of albite and saponite partially replacing plagioclase below 625 mbsf indicates a change in alteration conditions. This change may result in part because of slightly higher temperatures at depth as the lava/ dike boundary is approached or from interaction with more evolved fluid compositions (e.g., decreased $\mathrm{K} / \mathrm{Na}$ and elevated silica). Black, brown, and mixed halos are absent in lowermost lavas $(>900$ mbsf), and dark gray background alteration related to abundant saponite and pyrite is ubiquitous. Vertical vein sets become more common below $~ 900$ mbsf.

When compared with other basement sites (e.g., DSDP/ODP Sites 417 and 418 and Holes 504B and $896 \mathrm{~A})$, Hole $1256 \mathrm{D}$ contains a much smaller number of brown, mixed, and black alteration halos (Wilson, Teagle, Acton, et al., 2003; Alt, 2004). The abundance of carbonate veins in Hole 1256D is also lower than at many other sites (Coggon et al., 2010). Site 1256 is, however, quite similar to ODP Site 801, also in crust generated at a fast-spreading ridge, albeit 170 m.y. ago (Alt and Teagle, 2003). One important feature is the lack of any oxidation gradient with depth in Hole 1256D, in contrast to the stepwise disappearance of iron oxyhydroxide and celadonite in Hole 504B and the general downhole decrease in seawater effects at Sites 417 and 418 (Wilson, Teagle, Acton, et al., 2003; Alt, 2004). In contrast, alteration appears to have been concentrated into different zones that may be related to the architecture of the basement, such as lava morphology, distribution of breccia and fracturing, and the influence of these on porosity and permeability.

Below 1061 mbsf, subvertical intrusive contacts are numerous, indicating the start of a relatively thin, $\sim 350 \mathrm{~m}$ thick sheeted dike complex dominated by massive basalt. Some basalts have doleritic textures, and many are crosscut by subvertical dikes with common strongly brecciated and mineralized chilled margins. There is no evidence from core or geophysical wireline logs for major tilting of the dikes, consistent with subhorizontal seismic reflectors in the lower extrusive rocks that are continuous for several kilometers across the site (Hallenborg et al., 2003). Measurements of dike orientations by wireline imaging are in close agreement with direct measurements 
on recovered cores and indicate that the dikes at Site 1256 are slightly tilted away from the paleospreading axis $\left(\mathrm{dip} / \mathrm{dip}\right.$ direction $=79^{\circ} \pm 8^{\circ} / 053 \pm 23^{\circ}$ ) (Tominaga et al., 2009).

The secondary mineralogy of the rocks indicates a stepwise increase in alteration grade downhole from the lavas to the dikes, with low-temperature phases $\left(<150^{\circ} \mathrm{C}\right.$ phyllosilicates and iron oxyhydroxides) in the lavas giving way to dikes partially altered to chlorite and other greenschist facies minerals (at temperatures greater than $\sim 250^{\circ} \mathrm{C}$ ) (Fig. F12) (Alt et al., 2010). Within the dikes, alteration intensity and grade increase downward, with actinolite more abundant than chlorite below 1300 mbsf and hornblende present below 1350 mbsf, indicating temperatures approaching $\sim 400^{\circ} \mathrm{C}$ (Alt et al., 2010). The dikes have significantly lower porosity (mostly $0.5 \%-2 \%)$ and higher $P$-wave velocities and thermal conductivity than the lavas. Porosity decreases and $P$-wave velocity increases with depth in the dikes.

In the bottommost $\sim 60 \mathrm{~m}$ of the sheeted dikes (1348-1407 mbsf), basalts are partially to completely recrystallized to distinctive granoblastic textures characterized by granular secondary clinopyroxene and lesser orthopyroxene resulting from contact metamorphism by underlying gabbroic intrusions (Figs. F12, F13). Textural changes in oxide minerals indicate that the zone of metamorphic recrystallization may extend for $>90 \mathrm{~m}$ above the upper contact with the first gabbro interval. There is unequivocal evidence for hydrothermal alteration before and after the formation of the granoblastic textures and potentially small, irregular patches of partial melting (Koepke et al., 2008; France et al., 2009; Alt et al., 2010). Simple thermal calculations suggest that the two gabbro bodies so far intersected in Hole 1256D have insufficient thermal mass to be responsible for a 60 to $90 \mathrm{~m}$ thick high-temperature $\left(600^{\circ}-900^{\circ} \mathrm{C}\right)$ metamorphic halo if the intrusions are simple subhorizontal bodies (Koepke et al., 2008; Coggon et al., 2008). This feature requires either a much more substantial intrusion nearby or significant topography on the dike/gabbro boundary.

Aside from the granoblastic contact metamorphic assemblages in the basal dikes, hydrothermal mineralogy and inferred alteration temperatures of the lower dikes in Hole $1256 \mathrm{D}$ are generally similar to those in the lower dikes of Hole 504B (as high as $\sim 400^{\circ} \mathrm{C}$ ). The fact that the dike section at Site 1256 is much thinner than the one at Site 504 ( $\sim 350$ versus $~ 1000$ $\mathrm{m})$, however, indicates a much steeper hydrothermal temperature gradient in Hole $1256 \mathrm{D}\left(\sim 0.5^{\circ} \mathrm{C} / \mathrm{m}\right.$ versus $0.16^{\circ} \mathrm{C} / \mathrm{m}$ in Hole $504 \mathrm{~B}$ ).

Gabbro and trondhjemite intrusions into sheeted dikes at 1407 mbsf mark the top of the plutonic sec- tion (Figs. F12, F13). Two major bodies of gabbro were penetrated beneath this contact, with the $52 \mathrm{~m}$ thick upper gabbro (Gabbro 1) separated from the 24 $\mathrm{m}$ thick lower gabbro (Gabbro 2) by a $24 \mathrm{~m}$ screen of granoblastic basalts (Dike Screen 1). The textures and rock types observed in Hole 1256D are reminiscent of varitextured gabbros thought to represent a frozen melt lens between the sheeted dike complex and above the cumulate rocks in many ophiolites (e.g., MacLeod and Yaouancq, 2000; France et al., 2009).

Gabbro 1 is mineralogically and texturally heterogeneous, comprising gabbros, oxide gabbros, quartzrich oxide diorites, and small trondhjemite dikelets. Oxide abundance decreases irregularly downhole, and olivine is present in significant amounts only in the lower part of Gabbro 1. These rocks are moderately to highly altered by hydrothermal fluids to actinolite, hornblende, secondary plagioclase, epidote, chlorite, prehnite, and laumontite.

The intervening Dike Screen 1 is interpreted as an interval of sheeted dikes captured between the two intrusions of gabbros. Dike Screen 1 consists of finegrained meta-basalt similar to the granoblastic dikes overlying Gabbro 1. Dike Screen 1 is cut by a number of small quartz gabbro and tonalite dikelets of variable thickness $(1-10 \mathrm{~cm})$, grain size, and composition.

Gabbro 2 comprises gabbro, oxide gabbro, and subordinate orthopyroxene-bearing gabbro and trondhjemite that are similarly altered to Gabbro 1 and has clear intrusive contacts with the overlying granoblastic Dike Screen 1. Partially resorbed stoped dike clasts are entrained within both the upper and lower margins of Gabbro 2 (Fig. F13G). Gabbro 2 is characterized by an absence of fresh olivine, high but variable orthopyroxene contents (5\%-25\%), and considerable local heterogeneity. Oxide abundance generally diminishes downhole. The predominant rock type is orthopyroxene-bearing gabbro with gabbronorite in the marginal units. The lowermost rock recovered from Hole 1256D during Expedition 312 was a highly altered actinolite-bearing basaltic dike that lacks granoblastic textures; hence, it is interpreted to be a late dike that postdates the intrusion of the lower gabbro.

Relative to other well-studied upper ocean crust sections (e.g., Karson, 2002), Site 1256 shows a thick lava sequence and a thin dike sequence. Steady-state thermal models require that the conductive lid separating magma from rapidly circulating seawater thins as spreading rate increases, indicating that the thin dike sequence is a direct consequence of the high spreading rate. A thick flow sequence with many massive individual flows and few pillow lavas is a reasonable consequence of short vertical trans- 
port distance from the magma chamber and is similar to observations from the mid-segments of the fastest spreading ridges in the modern ocean (White et al., 2002). This is in direct contrast to spreading models developed from observations of tectonically disrupted fast-spread crust exposed in Hess Deep (Karson et al., 2002) that suggest regions of high magma supply should have thin lavas and thick dikes. Similarly, there is little evidence for tilting (at most 10 degrees) in Hole $1256 \mathrm{D}$ and no evidence for significant faulting. In contrast, the upper crust exposed at Hess Deep and in the Blanco Fracture Zone shows significant faulting and rotation within the dike complex (Karson et al., 2002), indicating that observations from those tectonic windows may be site specific and not widely applicable to intact ocean crust. The massive lava flow at the top of the Site 1256 basement indicates that faults with $\sim 50$ $100 \mathrm{~m}$ throws must exist relatively near to the ridge axis even in superfast spreading rate crust to provide the necessary relief to pond off the lava. At fastspreading ridges, such relief is typically developed $\sim 5$ to $10 \mathrm{~km}$ from the axis.

Marine seismologists have long been dividing the ocean crust into seismic layers: Layer 1 comprises low-velocity sediments $\left(V_{\mathrm{p}}<3 \mathrm{~km} / \mathrm{s}\right)$; Layer 2 has low velocity and a high velocity gradient, with $V_{\mathrm{P}}$ typically ranging from $\sim 3.5$ to $\sim 6.7 \mathrm{~km} / \mathrm{s}$; and Layer 3 has high velocity and a low velocity gradient $\left(V_{\mathrm{P}}\right.$ ranges from 6.7 to $7.1 \mathrm{~km} / \mathrm{s}$ ). There is a widespread perception that Layer 3 is equivalent to gabbro, even though Hole 504B has penetrated Layer 3 but not gabbro (Alt et al., 1996; Detrick et al., 1994). From regional seismic refraction data, the transition from seismic Layer 2 to Layer 3 at Site 1256 occurs at 1450-1750 mbsf (1200-1500 msb) (Wilson et al., 2003) (Figs. F9, F12). Shipboard determinations of seismic velocities of discrete samples are in close agreement with in situ measurements by wireline tools to $\sim 1320 \mathrm{mbsf}$, above the granoblastic dikes interval; below that depth, velocities are significantly lower than the sonic log, and the gabbro velocities range between $\sim 5.3$ and $6.4 \mathrm{~km} / \mathrm{s}$ (Swift et al., 2008). Contrary to expectation, porosity increases and $P$-wave velocities decrease stepwise downward from the lowermost dikes into the uppermost gabbro in Hole 1256D, as the result of the contact metamorphism of the granoblastic dikes and the strong hydrothermal alteration of the uppermost gabbros (Fig. F12). Porosity and velocity then increase downhole in the gabbro but are still $<6.5 \mathrm{~km} / \mathrm{s}$. Similar trends for porosity and velocity were observed in postcruise laboratory measurements at ambient pressure (Violay et al., 2010) and lithostatic pressure (Gilbert and Salisbury, 2011), albeit on a small suite of samples. However, the compressional velocities on these samples were as much as $\sim 800 \mathrm{~m} / \mathrm{s}$ higher in the gabbroic section, with $V_{\mathrm{P}}$ averaging $\sim 6.5 \mathrm{~km} / \mathrm{s}$ from the middle part of gabbro to the bottom of Gabbro 2. This difference may arise from the incomplete saturation of the samples during shipboard measurements (see "Physical properties" in the "Site 1256" chapter [Expedition 335 Scientists, 2012c]). Wireline velocity measurements end at the top of gabbro, but we interpret the gabbro intervals as within Layer 2 because a smoothed extrapolation of the downhole velocities will either have velocities $<6.5 \mathrm{~km} / \mathrm{s}$, still characteristic of Layer 2, or will have an exceptionally high gradient to higher velocities, also characteristic of Layer 2. Encountering gabbro at a depth clearly within Layer 2 reinforces previous inferences that factors including porosity and alteration (Detrick et al., 1994; Alt et al., 1996; Carlson, 2010) are more important than rock type or grain size in controlling the location of the Layer 2-3 transition. The position of the dike/gabbro boundary therefore appears to have little control over the seismic velocity structure of the crust (Alt et al., 1996; Detrick et al., 1994). Unfortunately, because the transition from Layer 2 to Layer 3 most likely lies beneath Hole $1256 \mathrm{D}$, we cannot yet determine what controls this transition at Site 1256.

\section{Summary of whole-rock igneous geochemistry from Site 1256}

Flows and dikes from Hole 1256D show a wide range of magmatic fractionation, from fairly primitive to evolved (Figs. F12, F14). Shallower than 600 mbsf, magma compositions are bimodal, with relatively evolved thick flows and more primitive thin flows. The lava pond includes rocks with the highest incompatible element compositions $\left(\mathrm{Zr}, \mathrm{TiO}_{2}, \mathrm{Y}\right.$, and $\mathrm{V})$ and lowest compatible element concentration $(\mathrm{Cr}$ and $\mathrm{Ni}$ ), suggesting that it is more evolved than other basalt from Site 1256 (Fig. F15). The initial division (based on Leg 206 lavas only) into high Zr$\mathrm{TiO}_{2}$, low $\mathrm{Zr}-\mathrm{TiO}_{2}$, and high $\mathrm{Zr}$ disappears with more data from Expedition 309/312. Rare samples from the lava pond fall off the dominant $Y$ versus $Z r$ and $\mathrm{TiO}_{2}$ versus $\mathrm{Zr}$ trends, suggesting possible minor variation in source compositions.

There are subtle variations in the basalt chemistry downhole, with a number of step changes or reversals of fractionation trends possibly indicating cycles of fractionation, replenishment, and, perhaps, assimilation (e.g., at $\sim 600,750,908$, and $1125 \mathrm{mbsf}$ ). Downhole geochemical compositions within the dike section are variable and do not define trends. Primary and evolved compositions are closely juxta- 
posed, as would be expected for vertically intruded magmas. The range of major element compositions in the dikes is similar to that of the overlying rocks, and the average composition of the dikes is indistinguishable from the average composition of the lavas (Figs. F12, F14).

The gabbros have highly variable bulk compositions. The uppermost gabbros have geochemical characteristics similar to the overlying dikes with mid-oceanridge basalt (MORB) chemistries (MgO 7-8 wt\%; Zr 47-65 ppm). Conversely, deeper in Gabbro 2 the rocks are significantly less fractionated and there are general downhole trends of increasing $\mathrm{MgO}, \mathrm{CaO}$, and $\mathrm{Ni}$ and decreasing $\mathrm{FeO}, \mathrm{Zr}$, and $\mathrm{Y}$. The uppermost rocks of Gabbro 2 are fractionated with MgO contents of $6.1 \mathrm{wt} \%$, but lower in the sequence $\mathrm{MgO}$ reaches $9.3 \mathrm{wt} \%$. Decreasing concentrations of $\mathrm{FeO}$ and $\mathrm{TiO}_{2}$ downhole suggest that Gabbro 2 is fractionated similarly to Gabbro 1 . The intrusive nature of both gabbro bodies and the chemical variations within them suggest that they intruded into the base of the sheeted dikes and underwent minor internal fractionation in situ, resulting in the observed general geochemical stratification. Partially resorbed xenoliths of granoblastic dikes within Gabbro 2 indicate that stoping of the intruded dikes may have contaminated the gabbro compositions.

There are linear trends between $\mathrm{MgO}$ versus $\mathrm{TiO}_{2}$, $\mathrm{FeO}, \mathrm{CaO}, \mathrm{Na}_{2} \mathrm{O}$, and $\mathrm{Zr}$, most likely resulting from fractional crystallization of a gabbro, with the fractionating assemblage consisting of clinopyroxene and plagioclase, as expected for relatively evolved basaltic magmas. The predicted composition of the cumulate gabbros generated during this fractional crystallization is very different from that of the gabbros drilled so far. Simple mass balance calculations indicate that the average basalt has lost $>30 \%$ of its original liquid mass as solid gabbro, implying the presence of at least $300 \mathrm{~m}$ of cumulate gabbro in the crust below the present base of the hole (Teagle, Alt, Umino, Miyashita, Banerjee, Wilson, and the Expedition 309/312 Scientists, 2006).

The gabbro compositions span a range similar to the flows and dikes but are on average more primitive, with higher $\mathrm{MgO}$ and lower $\mathrm{FeO}$, albeit still within the range of EPR basalts (Figs. F14, F15). Even though it is less fractionated, the average gabbro composition is evolved relative to candidates for primary magma in equilibrium with mantle olivine. Possible primary mantle melt compositions should have $\mathrm{Mg \#}$ of 70-78 and $\mathrm{MgO}$ of 9-14 wt\%. All flows and dikes and most gabbros are too evolved to be candidates for primary magma. Therefore, the residue removed from primary magma to produce the observed gabbro and basalt compositions must occur below the present base of Hole 1256D.

The compositional ranges of fresh lava and dike samples correspond to typical values for MORB for most major elements and many trace elements (Su and Langmuir, 2003) and are similar to those observed for the northern EPR (Fig. F10). A few incompatible elements, including $\mathrm{Na}$ and $\mathrm{Zr}$, have lower concentrations than observed for the modern EPR lavas, but the generally substantial overlap of compositions indicates similar process operated at the superfast spreading ridge that formed Site 1256 and the modern EPR. When trace elements are compared to EPR MORB, they are within one standard deviation of average, albeit on the relatively trace element-depleted side of MORB. For example, compared with first-order mid-ocean-ridge segments along the EPR, basalts from Site 1256 have low $\mathrm{Zr} / \mathrm{TiO}_{2}$ and $\mathrm{Zr} / \mathrm{Y}$. Although there is overlap among the segments and a large scatter in the data for each segment, $\mathrm{Zr} / \mathrm{TiO}_{2}$ and $\mathrm{Zr} / \mathrm{Y}$ appear to decrease with increasing spreading rate (Teagle, Alt, Umino, Miyashita, Banerjee, Wilson, and the Expedition 309/312 Scientists, 2006). The origin of this relationship remains unclear. Spreading rate may affect the extents of magma fractionation or partial melting of the mantle, or it may instead reflect regional scale mantle heterogeneity. To decrease trace element ratios to this extent would require $\sim 30 \%$ more melting at the superfast ridge, but this appears unlikely because of normal crustal thickness $(\sim 5.5 \mathrm{~km})$ at Site 1256 (Park et al., 2008).

The simplest model for mid-ocean-ridge magma plumbing is that the melt lens imaged by MCS experiments is the magma chamber where crystal-rich residues are separated from the evolved lavas that reach the seafloor. Hole $1256 \mathrm{D}$ gabbros are texturally and compositionally similar to varitextured gabbros at the base of the sheeted dike complex in Oman interpreted to be axial melt lenses (Fig. F16) (e.g., MacLeod and Yaouancq, 2000; France et al., 2009). If the gabbro bodies so far encountered in Hole 1256D were intruded on-axis, and if they extended roughly horizontally for at least hundreds of meters, at 52 and $24 \mathrm{~m}$ thick they would have dimensions appropriate for axial low-velocity zones imaged by MCS experiments at intermediate to fast-spreading ridges (Singh et al., 1998). However, these bodies could not have been the site of primary magmatic fractionation. Chilled margins against the underlying dike screens precludes segregating a crystal residue that subsides to form the lower crust as in the gabbro glacier model, and its overall fractionated composition requires that crystals have been segregated elsewhere. This implies that sills or other bodies containing cumulate materials must exist deeper in the crust 
and/or below the crust/mantle boundary, consistent with recent models based on lower crustal sections of ophiolites (e.g., Boudier et al., 1996; Kelemen et al., 1997; MacLeod and Yaouancq, 2000) and some marine geophysical experiments (Crawford and Webb, 2002; Dunn et al., 2001; Garmany, 1989; Nedimovic et al., 2005; Canales et al., 2009). However, the gabbro glacier mode of accretion or a combination of the gabbro glacier and sheeted sills models cannot yet be rejected, as fractionated gabbros in the dikegabbro transition zone are not unexpected, and the predicted region of cumulate rocks could still exist just below the present maximum depth of Hole 1256D. Deepening Hole 1256D by as little as a few hundred meters would provide the critical samples that should enable answering this outstanding basic question.

\section{Scientific objectives}

To date, the Superfast Spreading Crust campaign has accomplished the significant initial operational objective of drilling a section of intact upper ocean crust down into gabbros (Wilson et al., 2006; Teagle, Alt, Umino, Miyashita, Banerjee, Wilson, and the Expedition 309/312 Scientists, 2006). This is a major scientific and engineering achievement, but with only $\sim 100 \mathrm{~m}$ penetration into a complicated dike/ gabbro boundary transition zone, many scientific objectives of the Superfast Spreading Crust campaign remain unfulfilled (ODP Proposal 522Full-2; D.S. Wilson et al., unpubl. data). Before we outline specific objectives for Expedition 335 operations in Hole $1256 \mathrm{D}$, it is informative to predict what might be encountered with deeper drilling at this site.

\section{Rocks expected with deeper drilling}

With deeper drilling, Hole 1256D will explore unknown territory, and hence we must use geological analogs to predict what rocks underlie the current base of Hole 1256D. Field mapping from the lower crust of the Oman ophiolite (e.g., Kelemen and Aharonov, 1998; MacLeod and Yaouancq, 2000; Nicolas and Boudier, 1991; Nicolas et al., 2000) and submersible studies and shallow drilling of EPR crust at Hess Deep (e.g., Francheteau et al., 1992; Gillis, 1995; Karson et al., 1992, 2002; Natland and Dick, 1996) may be useful in this respect. However, because of the difficulties of detailed mapping and sampling using submersibles and remotely operated vehicles (ROVs) and the lack of deep drilling of the dike/gabbro boundary in Hess Deep, the well-exposed outcrops in Oman arguably provide the best available guide to the upper plutonic section of fast-spreading ocean crust (Fig. F16). Detailed geological mapping from the dike/gabbro boundary down toward the harzburgites of the mantle (MacLeod and Yaouancq, 2000) in Wadi Abyad, Oman, provides one of the most useful templates of what might be encountered with deeper drilling in Hole 1256D (see also Pallister and Hopson, 1981; Nicolas et al., 1996).

Similar to Hole $1256 \mathrm{D}$, the rocks directly underlying the sheeted dikes complex in Wadi Abyad are varitextured gabbros and microgabbros with subordinate ferrobasalts. The varitextured gabbros are $\sim 150 \mathrm{~m}$ thick and show extreme variability in texture, grain size, and chemical composition at centimeter to meter scale and are petrographically very similar to the gabbroic rocks described so far from Hole 1256D. The Oman varitextured gabbros also display a wide range of compositions from those similar to cumulate gabbros to compositions more fractionated than the overlying dikes and lavas (e.g., Mg\# 38-82). An average composition weighted according to outcrop abundance indicates that this horizon ( $\mathrm{Mg \#} 65)$ (MacLeod and Yaouancq, 2000) is a pooled basaltic liquid sourced from deeper in the crust (Kelemen and Aharonov, 1998; MacLeod and Yaouancq, 2000; Sinton and Detrick, 1992) similar to the gabbros recovered from Hole 1256D.

The varitextured gabbros grade over a few meters into $\sim 650 \mathrm{~m}$ of foliated gabbros with steeply dipping, prominent magmatic foliations oriented subparallel to the strike of the overlying sheeted dikes. These rocks show only weak modal variations. These foliated gabbros pass down into layered gabbros that make up the bulk of the plutonic section in Oman. These layered gabbros exhibit Moho-parallel modal layering defined by variations in the proportion of olivine, clinopyroxene, and plagioclase. Both the foliated and layered gabbros have "cumulate" compositions with high bulk Mg\# (>75). Very low $\mathrm{P}_{2} \mathrm{O}_{5}$ concentrations $(<0.02 \mathrm{wt} \%)$ indicate low $(<5 \%)$ proportions of trapped intercumulus liquids. Similar but less detailed observations are recorded from Hess Deep (Francheteau et al., 1992; Gillis, 1995).

With a few hundred meters of drilling below the section of Hole 1256D drilled during Expedition 312, we anticipate breaching the current dike-gabbro transition zone, followed by penetration through a narrow (100-200 m) zone dominated by varitextured gabbros (Fig. F16). Beneath these rocks we should drill into cumulate rocks, perhaps with strong subvertical magmatic foliations and only weak modal layering. Modally layered gabbros with subhorizontal cumulate mineral layers are predicted to occur within $1000 \mathrm{~m}$ of the current bottom of Hole 1256D. 


\section{Questions addressed by deepening Hole 1256D}

Specific scientific questions that would be addressed by deepening Hole $1256 \mathrm{D}$ a significant distance into cumulate gabbros during Expedition 335 and possible future expeditions are

- What is the major mechanism of magmatic accretion in crust formed at fast spreading rates? Is the lower crust formed by gabbro glaciers or sheeted sills or by some mixed or unknown mechanism?

- How is heat extracted from the lower oceanic crust?

- What is the geological significance of the seismic Layer 2/3 boundary at Site 1256?

- What is the magnetic contribution of the gabbro layer? Can the magnetic polarity structure of the lower crust be used to constrain cooling rates?

\section{Is the lower crust formed by gabbro glaciers or sheeted sills?}

There are two principal models for the accretion of the lower crust at fast-spreading mid-ocean ridges (Fig. F17); the "Gabbro Glacier" model (Henstock et al., 1993; Phipps Morgan and Chen, 1993) and accretion by "Sheeted Sills" (e.g., Boudier et al., 1996; Kelemen et al., 1997; Korenaga and Kelemen, 1997; MacLeod and Yaouancq, 2000). Gabbro glacier models postulate that the entire lower crust is formed by ductile flow of solid material downward and outward from a single, shallow axial magma chamber. In contrast, sheeted sill models are based on the crystallization of gabbro throughout the lower axial crust, with, for the end-member model, negligible downward flow of solid material (Kelemen et al., 1997).

High-level mafic cumulate rocks that balance the fractionated compositions of the dikes and lavas are a predicted consequence of both the gabbro glacier and sheeted sills modes of accretion, and cumulates should occur within a few hundred meters of the dike/gabbro boundary. Sampling the cumulate section through drilling will allow us to test the relative importance of these end-member mechanisms of crustal accretion. A gabbro glacier mode of crustal accretion will result in specific chemical and structural consequences for the lower oceanic crust that will be observable in drill core (Figs. F16, F17). One would predict that (1) the upper plutonics and the lower crust have similar compositions and (2) that there will be increasing amounts of strain and subsolidus deformation in rocks with depth in the ocean crust.
Test 1.1: Gabbro glacier models predict no variation in cumulate composition (e.g., Mg\#) with depth

If all solidification of the lower crust takes place in the shallow melt lens, then there should be no vertical variation in the composition of the cumulates (e.g., Mg\# of mafic phases). However, if the stacked sills model is correct, then we should see a gradual increase in the Mg\# of the mafic phases with increasing depth in the section or a random vertical repetition of variable $\mathrm{Mg} \#$ values. Studies of high-level plutonic rocks in Oman do show chemical trends with depth over a scale of kilometers (e.g., MacLeod and Yaouancq, 2000; S. Miyashita, pers. comm., 2005), although small-scale (meters) chemical layering at the very base of the Oman crust is not well correlated with depth (Korenaga and Kelemen, 1998). Chemical layering in cumulate rocks should put constraints on melt migration and the size of magma lenses. Studies of cyclic variations in mineral trace element concentrations in Oman suggest the size of melt lenses is on the order of meters to hundreds of meters (Browning, 1984; Korenaga and Kelemen, 1997). Modeling the effects of melt flow through porous media such as a chemically layered crystal mush indicates that trace element correlations should be obliterated by melt-crystal reaction in hundreds to thousands of years (Korenaga and Kelemen, 1998). In Oman, chemical layering is well correlated for different elements and minerals, suggesting that the upwelling of melt through a crystal mush at the ridge axis cannot have occurred (Korenaga and Kelemen, 1998). These careful petrological tests have not been applied to rocks sampled from in situ ocean crust. The presence or absence of geochemical trends in whole rock and mineral chemistry will place important boundaries on mechanisms of melt migration and magma emplacement in the lower oceanic crust.

\section{Test 1.2: Gabbro glacier models predict increasing strain with depth}

Formation of the lower crust from a single, highlevel melt lens requires very large increases in strain with depth in the crust (Henstock et al., 1993; Phipps Morgan and Chen, 1993) that will manifest as stronger shape and lattice fabrics. Such high strains have not been reported from rocks sampled in Hess Deep, but to date textural and structural measurements to estimate the extent of strain have not been employed on rocks from intact sections of fast-spread ocean crust. Lack of evidence for increasing strain with depth would favor the multiple sills model. However, increasing strain with depth has 
been reported for the uppermost part of the foliated gabbro section of the Oman ophiolite (Nicolas et al., 2009), suggesting that subsidence does occur from the upper melt lens. Together with the evidence for sills, these observations may support a mixed model (Boudier et al., 1996).

\section{Is the plutonic crust cooled by conduction or hydrothermal circulation?}

The balance between conductive and hydrothermal cooling is key to understanding the thermal structure of the ocean crust, as well as for estimating the magnitude of hydrothermal chemical exchanges between the crust and oceans. This is because the latent heat of crystallization of gabbro is a significant fraction $(\sim 1 / 3)$ of the total heat available from the cooling and crystallization of a basaltic melt. Where crystallization takes place in the crust is one of the major differences between the end-member models (Fig. F17). Were the gabbros, particularly cumulate gabbros, cooled by conduction or hydrothermal fluids (Manning et al., 1996; Maclennan et al., 2005)? Were hydrothermal interactions pervasive or restricted to veins, and did alteration occur at black smoker or higher temperatures $\left(350^{\circ}-800^{\circ} \mathrm{C}\right)$ ? Or did most of the hydrothermal interactions occur later at subgreenschist facies conditions (e.g., prehnite and clays) some distance away from the ridge? What is the role of faults in channeling recharge and discharge fluids to and from the lower crust? How do alteration effects relate to physical properties and the seismic layering of the crust?

Simple gabbro glacier models suggest much slower rates of cooling for the lower crust $\left(\sim 0.02^{\circ} \mathrm{C} / \mathrm{y}\right)$ than those required to match recent seismic tomographic models and compliance results from the EPR (Crawford and Webb, 2002; Crawford et al., 1999; Dunn et al., 2001). Multiple sills models require deep nearaxis hydrothermal cooling and rapid cooling rates $\left(\sim 0.1^{\circ} \mathrm{C} / \mathrm{y}\right)$; otherwise, large-scale remelting of the lower crust will occur (Chen, 2001). However, deep hydrothermal cooling may also occur in some geometries of gabbro glacier models. Although the extent of hydrothermal cooling of the lower crust must be closely linked to the mode of magmatic accretion, quantifying these rates of cooling is a separate, important, and independently achievable objective.

\section{Test 2.1: Are cooling rates much greater than expected from conductive heat transfer in the cumulates?}

Recent petrological studies of the Oman ophiolite and Hole 504B have developed techniques for estimating the cooling rates of dikes and gabbros (Coogan et al., 2005a, 2002, 2005b; VanTongeren et al., 2008). The Ca in olivine geospeedometer devel- oped and refined by Coogan and others will allow the robust estimation of vertical variations in cooling rate that are sensitive enough to identify departures from conductive cooling profiles. Li measurements of coexisiting igneous plagioclase and clinopyroxene provide an independent cooling geospeedometer (Coogan et al., 2005b).

\section{Test 2.2: Quantify fluid evolution and fluxes through lower crust using trace elements and Sr and stable isotopic profiles}

Well-established petrologic and geochemical approaches will be used to characterize the nature and relative timing of hydrothermal exchange between seawater and the lower crust that complement the trace element cooling rate studies of magmatic minerals discussed above.

Mineral geothermometers, crosscutting vein mineral sequences coupled with trace elements and strontium, and stable isotopic measurements of whole-rock samples and mineral separates can be used to establish the chemistry of fluids reacting with the lower crust (Gregory and Taylor, 1981; Bach et al., 2004; Coggon et al., 2004; Gillis, 1995; Manning et al., 1996; Teagle et al., 1998a, 1998b). By looking at ${ }^{87} \mathrm{Sr}$ and ${ }^{18} \mathrm{O}$ profiles away from hydrothermal mineral veins, we can establish the scale of fluid channeling in the lower crust (e.g., Bickle, 1992; Teagle and Bickle, 1993). The advection of seawater-derived tracers, particularly when whole-rock and mineral data are closely coupled, have proved useful for estimating time-integrated hydrothermal fluid fluxes (Bickle and Teagle, 1992; Coogon, 2006; Gillis et al., 2005; Teagle et al., 2003).

\section{What is the geological significance of the seismic Layer $2 / 3$ boundary at Site 1256 ?}

Understanding the seismic structure of the ocean crust requires the calibration of remotely obtained regional geophysical data against physical properties and petrological measurements of geological samples recovered from within deep ocean boreholes. Hole 504B remains the only site where the seismic Layer $2 / 3$ boundary has been penetrated (e.g., Detrick et al., 1994). At that location, the change in seismic gradient clearly occurs within the dikes and the Layer 2-3 transition reflects changes in bulk physical properties associated with an increased grade of hydrothermal alteration (albite + chlorite to amphibole + plagioclase). In Hole 1256D, gabbros have been recovered from crust clearly within seismic Layer 2 based on shipboard, wireline, and seismic refraction velocity measurements (Figs. F8, F12) (Swift et al., 2008; Guerin et al., 2008; Gilbert and Salisbury, 2011). The depth of the Layer $2 / 3$ boundary esti- 
mated during site survey seismic experiments at Site 1256 is between 1450 and 1750 mbsf. Drilling deeper at Site 1256 would provide a second test of the geological meaning of the seismic layering of the ocean crust, where the Layer 2-3 transition lies beneath the first appearance of gabbro.

\section{What is the magnetic contribution of the gabbro layer? Can the magnetic polarity structure of the lower crust be used to constrain cooling rates?}

Site 1256 was deliberately located $\sim 5 \mathrm{~km}$ on the old side of the C5Cr-C5Bn magnetic reversal (Fig. F7A). Preliminary interpretation of the downhole magnetic field indicates that the flow and dike section has reversed polarity. Interpretation of paleomagnetic samples has been severely hampered by drilling overprint. However, the downhole magnetic field is more diagnostic than analysis of samples for determining the average in situ magnetization of a particular crustal layer. Very preliminary modeling of the downhole field intensity suggests that the flow and dike layers contribute about two-thirds of the amplitude of the marine magnetic anomalies measured at the sea surface, mostly from the thicker flow units. In addition to quantifying the contribution of gabbros to the sea-surface anomalies, magnetic measurements from a significantly deepened Hole 1256D could help determine whether the middle crust cools quickly by convection or slowly by conduction. The blocking temperature at which magnetization becomes stable over geologic time is $\sim 400^{\circ} \mathrm{C}$. The position of the site indicates that the Earth's field changed from reversed to normal polarity 50-80 k.y. after most dikes and the lower extrusives formed. End-member models for hydrothermal circulation therefore predict very different observations of the polarity structure of the middle and lower crust. Models for deep, young hydrothermal circulation (e.g., Maclennan et al., 2005) predict that reversed polarity should continue to near the base of the crust. In contrast, models with young hydrothermal circulation largely restricted to the more porous upper crust (e.g., Henstock et al., 1993) predict that normal polarity should be encountered within a few hundred meters of the base of high-volume circulation, potentially within the penetration of an additional single drilling expedition.

\section{Operations}

\section{Drilling strategy for Hole 1256D}

Leg 206 and Expedition 309/312 made significant progress in recovering an intact section of the upper oceanic crust through the erupted lavas and sheeted dikes and into the uppermost gabbros. Average rates of recovery and penetration are summarized in Figure F18 and Table T2. The inverse relationship between spreading rate and depth to axial melt lenses has been confirmed, supporting the strategy of drilling in crust formed at a superfast spreading rate to achieve the first upper crustal penetration. However, fundamental questions regarding the formation of ocean crust remain. The principal goal of Expedition 335 's return to Hole $1256 \mathrm{D}$ was to deepen the hole sufficiently into plutonic rocks (a few hundred meters) to obtain definitive answers to long-standing questions about the structure and composition of the oceanic crust and about mechanisms of crustal accretion (these ideas are developed in greater detail in "Background and geological setting" and the "Deep drilling of intact ocean crust: harnessing past lessons to inform future endeavors" chapter [Expedition 335 Scientists, 2012a]).

Operational planning for Expedition 335 was informed by three principal sources:

1. The Operations teams' experiences during Leg 206 and Expedition 309/312 to Hole 1256D and previous deep basement coring by scientific ocean drilling;

2. Aspects of the IODP Operations Review Task Force (ORTF) Meeting "Expeditions 309/312 Superfast Spreading Rate Crust" (ORTF-3, June 2006; see 309_312_ORTF.PDF in REPORTS in "Supplementary material"); and

3. A US Implementing Organization (USIO) position paper, "Operational requirements for returning to Hole 1256D" (September 2006; see MOHO_2006.PDF in REPORTS in "Supplementary material").

The recommendations of the Expedition 309/312 ORTF indicate an understanding of the nonstandard requirements of deep basement drilling and echo the suggestions made by the Co-Chief Scientists of those expeditions (Teagle, Alt, Umino, Miyashita, Bannerjee, and the Expedition 309/312 Scientists, 2006; see 309_312_COCHIEF.PDF in REPORTS in "Supplementary material"). Three recommendations in the ORTF report pertinent to operations during Expedition 335 were

1. To investigate alternate scheduling strategies (e.g., at-sea crew changes and lengthening standard expedition durations to maximize on-site time for deep drilling objectives; Recommendation ORTF-309/312-03),

2. To investigate and prioritize avenues for enhancing coring/drilling capability (particularly of hard formations) for deep-drilling programs (Recommendation ORTF-309/312-11), and 
3. To build on the experiences of IODP Phase 1 expeditions and actively explore future applications of drilling muds (particularly those with heavy lifting capability) for riserless hole cleaning and stabilization (Recommendation ORTF309/312-12).

Unfortunately, there has been only modest progress on these recommendations in the 5 years since the 309/312 ORTF meeting, with a half-length expedition initially scheduled by the Science Advisory Structure for the return to Hole 1256D and an absence of new drilling and coring options for hard formations and hole cleaning.

The IODP Science Planning Committee requested in 2006 (SPC Consensus 0603-19) that the USIO identify the operational requirements for further drilling in Hole $1256 \mathrm{D}$. Texas A\&M University (TAMU) engineers from the USIO presented their operational plan to an audience of scientists and independent drilling engineers at the Mission Moho Workshop (Portland, Oregon, 7-9 Sept 2006, www.iodp.org/ mission-moho-workshop/) for technical review. There was consensus support for the plan proposed (see MOHO_2006.PDF in REPORTS in "Supplementary material").

The USIO considered four deepening scenarios:

1. Resume rotary core barrel (RCB) coring in Hole $1256 \mathrm{D}$ using large-volume (100-150 bbl) highviscosity mud sweeps combined with frequent bit trips,

2. Enlarge the hole to $181 / 2$ inches to isolate the out-of-gauge section using $13 \%$ inch casing,

3. Forego $13 \frac{3}{8}$ inch casing and enlarge the hole to $14 \%$ inches to isolate the out-of-gauge section using $10^{3 / 4}$ inch casing, and

4. Offset and start a new hole following the casing strategy employed during Leg 206.

Two key points were noted by the USIO and independent engineers at the Mission Moho Workshop:

1. Hole $1256 \mathrm{D}$ was in excellent condition at the end of Expedition 312, and remedial engineering operations such as reaming and casing are premature.

2. Neither the offshore industry nor scientific ocean drilling operators have ever attempted to open up an existing deep basement hole to any significant depth (hundreds of meters) in basalt and insert casing.

Regardless of the casing strategy proposed (scenarios 2 or 3), attempting to open any portion of Hole $1256 \mathrm{D}$ to accommodate casing would require significant new hardware, numerous pipe trips, and extend over several expeditions. Such operations would re- quire unproven technology and would be extremely challenging with substantial risk of irreparable damage to Hole $1256 \mathrm{D}$ without any further coring or recovery. The USIO and independent experts felt that approaches 2 and 3 are not viable options and recommended that they were not considered further.

The preferred USIO approach was strategy 1: resuming RCB coring with frequent large-volume high-viscosity mud sweeps (Recommendation ORTF-309/ 312-12). During Expedition 309/312, large-volume mud sweeps were effective at clearing cuttings from the hole. However, because of the end of Phase I operations, mud stock depletion precluded the vigorous implementation of this approach throughout the whole of Expedition 312. The refitted R/V JOIDES Resolution should be equipped to handle the necessary supplies to maintain an aggressive mud program. Following the recommendations of the IODP Expedition 309/312 ORTF, the JOIDES Resolution was stocked with at least $60 \mathrm{~T}$ of sepiolite and attapulgite for use during Expedition 335.

Assuming reasonable hole conditions and an average rate of penetration (ROP) comparable to previous coring in this hole, TAMU engineers estimated that this approach should deepen Hole 1256D 350 m with 39 days on site (Teagle et al., 2010). The engineering and design lessons learned from a few hundred meters deeper penetration of intact ocean crust would be invaluable in planning and exploiting future deep penetration targets.

Further deepening of Hole 1256D using large mud sweeps is the only strategy that begins with coring, is the most likely to return samples from deeper in the hole, and has the largest possibility of building on the tremendous success of previous deepening operations on Expedition 309/312 that employed proven drilling techniques.

Before conditioning the hole for further deepening, an attempt would be made to acquire an equilibrium temperature profile and recover a water sample before the thermal structure of the crust is perturbed by cleaning and drilling operations (see "Expedition 335 operations"). We planned to reenter the hole with a tricone drilling bit on a bit release and slowly descend past the zone around 900 mbsf that caused an obstruction during Expedition 312. If the hole was clear, we would withdraw the pipe, drop the bit, and reenter to below the rat hole to allow logging with the triple combination (triple combo), including the Modular Temperature Tool (MTT). If the wireline conditions were suitably benign, we would attempt to take a borehole water sample from near the bottom of the hole using the water-sampling temperature probe (WSTP). 


\section{Expedition 335 operations}

\section{Port call}

All Expedition 335 scientists transferred from their hotel in San Jose, Costa Rica, to Puntarenas, Costa Rica, and moved onto the vessel on Thursday, 14 April 2011, except for one whose travel was delayed by 3 days. The morning of Friday, 15 April, the CoChief Scientists participated in a press conference at the Marine Biology Station of the Universidad Nacional Costa Rica, located near the wharf where the JOIDES Resolution was docked. Regional visitors toured the ship in the afternoon. The final science party member arrived on board on Saturday, 16 April.

\section{Transit}

The last line was released on 17 April 2011 at $0420 \mathrm{~h}$, and the vessel began transit to Site $1256\left(6^{\circ} 44.2^{\prime} \mathrm{N}\right.$, $\left.91^{\circ} 56.1^{\prime} \mathrm{W}\right)$ at $0430 \mathrm{~h}$. The $478 \mathrm{nmi}$ voyage to Hole $1256 \mathrm{D}$ was accomplished at an average speed of 10.6 kt. The vessel was positioned on the established coordinates of the hole at $0115 \mathrm{~h}$ on 19 April. The water depth established during Leg 206 was 3645.4 meters below rig floor (mbrf).

The final depth of the hole at the end of Expedition 312, when it was last visited in December 2005, was 1507.1 mbsf. Below is a narrative of the operations conducted in Hole 1256D from this time (Table T3).

\section{Opening Hole 1256D (19-23 April 2011) \\ Run 1}

Hole $1256 \mathrm{D}$ was reentered with a hard formation Smith 97/8 inch F9 tricone bit (Fig. F19A) affixed to a mechanical bit release (MBR) and four-stand bottomhole assembly (BHA) (see the "Appendix: Superfast Spreading Crust acronyms" chapter for definitions of all acronyms). The initial objective was to test whether the hole was open to 1100 mbsf without circulation or rotation so that, if clear, an equilibrium temperature profile could be run to 1350 mbsf using the MTT logging suite. This would have been followed by a borehole water/microbiology sampling run using the WSTP according to plan (Teagle et al., 2010).

The drill string was lowered to $920 \mathrm{mbsf}$, where it encountered a ledge precluding the planned wireline operations. This interval had impeded smooth transit of the drill string during Expedition 312. The wireline caliper, FMS, and Ultrasonic Borehole Imager (UBI) logs from that expedition indicate an eroded zone from 920 to 935 mbsf (see "Observations of highly out-of-gauge interval (920-960 mbsf)" for more detail). Starting at $2330 \mathrm{~h}$ on 19 April 2011, and for $32 \mathrm{~h}$ until $0600 \mathrm{~h}$ on 21 April, the drillers attempted to work past the obstruction without success, and the drill string was recovered.

\section{Run 2}

A more aggressive Reed 978 inch tricone bit (International Association of Drilling Contractors [IADC] Type 517) (Fig. F19B), usually employed in softer formations, was mounted along with a tandem set of junk basket subs, and Hole $1256 \mathrm{D}$ was reentered for the second time at $0105 \mathrm{~h}$ on 22 April 2011. Drilling on the bridge at $\sim 922$ mbsf resumed at $0445 \mathrm{~h}$ and continued to $2100 \mathrm{~h}(16.3 \mathrm{~h})$ without discernible progress. The drill string was recovered, with the bit clearing the rotary table at $0605 \mathrm{~h}$ on 23 April. The contents of the junk baskets were examined and found to contain angular coarse sandy basaltic chips along with a few small $(2-3 \mathrm{~cm})$ subrounded basaltic pebbles, consistent with the rocks cored when this interval was first drilled during Expedition 309. After discussing options with the on-board scientific leadership, it was decided that placing a cement plug at and above the bridge could possibly stabilize the zone and allow us to advance past the obstruction.

\section{Cementing and reopening Hole 1256D (23 April-3 May 2011)}

\section{Run 3}

A cementing assembly was made up of the used Reed 978 inch tricone bit without jets and two stands of drill collars. Hole 1256D was reentered for the third time at $1520 \mathrm{~h}$ on 23 April 2011. After the driller tagged the bridge with the bit at 922 mbsf, the circulating head was made up to the drill string and tested to 1500 psi. Five bbl of 16 ppg (pounds per US gallon; specific gravity 1.9) blended cement was pumped into the hole and chased with a column of seawater equal to the volume of the drill string. The drill pipe was then pulled back to 807 mbsf, where an additional seawater flush consisting of three drill string volumes was pumped through the system. After rigging down the cementing equipment, the drill pipe was recovered, with the bit clearing the rotary table at $0515 \mathrm{~h}$ on 24 April.

\section{Run 4}

The Reed bit was replaced with a new 97/8 inch tricone bit (Atlas HP61), and the drill string was deployed to 1596 mbrf. Hole 1256D was reentered for the fourth time at $1655 \mathrm{~h}$ on 24 April 2011 to test the result of the cementing operation. The bit tagged the bridge at $922.0 \mathrm{mbsf}$, indicating that the $5 \mathrm{bbl}$ of cement deployed earlier was not sufficient to fill the cavity above the obstruction. The driller's effort to wash and ream past the ledge met with high erratic torque and was given up after $1 \mathrm{~h}$. The drill string 
was tripped to the surface, with the bit clearing the rotary table at $0615 \mathrm{~h}$ on 25 April.

\section{Run 5}

The cementing assembly was deployed for the second time, with the bit entering the reentry cone for the fifth time at $1445 \mathrm{~h}$ on 25 April 2011. The bit was placed at $922 \mathrm{mbsf}$, and this time $50 \mathrm{bbl}$ of 15 ppg cement was pumped into the hole. The bit was recovered at $0345 \mathrm{~h}$ on 26 April.

\section{Run 6}

A drilling assembly with an Atlas tricone bit was redeployed, and at $1520 \mathrm{~h}$ on 26 April 2011, Hole $1256 \mathrm{D}$ was reentered for the sixth time during this expedition. The top of the cement plug was tagged at $882 \mathrm{mbsf}$. The $40 \mathrm{~m}$ cement plug was drilled out at an average ROP of $10.7 \mathrm{~m} / \mathrm{h}$. At $2230 \mathrm{~h}$ on 26 April, washing and reaming the hole at $\sim 920$ mbsf resumed, and it continued until $0600 \mathrm{~h}$ on 28 April with no apparent progress. The driller worked stuck pipe for $1 \mathrm{~h}$ during this time interval. The drill string was recovered to change the bit, which had accumulated $33.3 \mathrm{~h}$ of work. The used bit (Fig. F19C) was found to be in gauge and exhibited little wear on the cones and bit body. The two junk baskets were emptied (Fig. F19D) and contained basaltic cuttings ranging from fine angular sand to small pebbles. Rare small (as large as centimeter-scale) chunks of cement were also recovered. The quantity of material was noticeably less than that from the previous junk basket deployment (Run 2).

\section{Run 7}

A new hard formation Smith Q7JS (IADC code 735) tricone bit (Fig. F19E) was picked up and deployed with the drilling assembly. The nozzles were reduced to $14 / 32$ inches from the usual $16 / 32$ inches to increase the downhole hydraulic horsepower. Junk baskets were not added to the BHA to reduce the risk of downhole hardware failure. The bit entered the reentry cone for the seventh time of the expedition at $0135 \mathrm{~h}$ on 29 April 2011. Washing and reaming resumed, and perseverance was finally rewarded when the bit passed through the obstruction at $922 \mathrm{mbsf}$ shortly before midnight on 29 April. The pipe got stuck for $2 \mathrm{~h}$ at $1162 \mathrm{mbsf}$. The total depth achieved during Expedition 312 (1507.1 mbsf) was reached at $0915 \mathrm{~h}$ on 1 May. A total of $6 \mathrm{~m}$ of hard fill was encountered at the bottom of the hole, which was ground and removed before the bore was flushed with a $100 \mathrm{bbl}$ high-viscosity mud sweep. The wiper trip to 890 mbsf was without incident. A pill of 60 bbl of heavy mud was spotted across the zone extending from 920 to 960 mbsf to keep the formation from bridging over the open hole prior to retrieving the pipe trip to the surface.

\section{Run 8}

The cementing assembly was deployed for the third time of the expedition with the bit entering the reentry cone for the eighth time at $1300 \mathrm{~h}$ on 2 May 2011. The bit was placed below the unstable zone at 960.5 mbsf, and 65 bbl of 15 ppg cement was pumped into the hole. The intent of this operation was to fill and stabilize the washed out and apparently unstable portion of the hole below 922 mbsf (see "Observations of highly out-of-gauge interval (920-960 mbsf)"). This region was not accessible prior to drilling through the ledge. The drill string was flushed with a large volume of seawater prior to withdrawal from the hole. The drill string was tripped to the surface, and the BHA was recovered by 0315 h on 3 May.

\section{Coring (3-7 May 2011) \\ Run 9}

An RCB coring assembly made up with a Rock Bit International (RBI) C9 hard formation coring bit, 11 controlled length drill collars, a tapered drill collar, six joints of $5 \frac{1}{2}$ inch drill pipe, and associated subs was deployed at $0630 \mathrm{~h}$ on 3 May 2011. The bit reentered the cone for the ninth reentry of the expedition at $1235 \mathrm{~h}$. Thought was given to penetrating the cement plug with a center bit, but it was decided that coring the cement would be more efficient and keep the annulus cleaner. The driller tagged the cement at 924 mbsf and began coring at $1745 \mathrm{~h}$ on 3 May (ghost Cores 335-1256D-G1 through G6) (Table T4). At $1330 \mathrm{~h}$ on $4 \mathrm{May}$, the cement plug was penetrated and the remaining portion of the hole was washed (wash Core 7W) (Table T4) and reamed to bottom by the early morning of 5 May. Rotary coring in Hole $1256 \mathrm{D}$ began at $0145 \mathrm{~h}$ on 5 May, which was exactly 16.0 days after arriving on station. Rotary coring advanced from 1507.1 to $1520.2 \mathrm{mbsf}$ (Cores 335-1256D-235R through 238R) (Table T4) by 1200 $\mathrm{h}$ on 6 May, using nonmagnetic core barrels without liners to reduce jamming and increase recovery. Coring was difficult with occasional erratically high torque. Overpull of as much as $60,000 \mathrm{lb}$ was frequently needed to keep the drill string free. When the last $2 \mathrm{~m}$ of advance required nearly $12 \mathrm{~h}$, the core barrel was recovered and found to contain only three pebbles. Initially, it was thought that the bit throat might be jammed, which is not uncommon in hard rock coring. However, examination of the core catcher sub located at the bottom of the core barrel showed evidence of grinding and abrasion 
damage, indicating a serious mechanical problem at the bit (Fig. F19F).

The drill string was recovered, with the bit clearing the rotary table at $0545 \mathrm{~h}$. The bit was totally unrecognizable (Fig. F19G, F19H). The body of the bit was honed to a smooth profile at the bottom and on the sides, earning it the name "Stumpy." The bit was missing all four cones, four legs, and core guides. The bit spiral stabilizer blades and embedded tungsten carbide inserts were also absent. The severity of the damage indicated that the bit had continued to rotate hours after experiencing failure, likely as long as $10 \mathrm{~h}$, based on changes in penetration rates. This spectacular failure was masked by the difficult drilling conditions $>5 \mathrm{~km}$ beneath the hull.

\section{Cleaning, milling, and reaming (7-26 May 2011)}

\section{Run 10}

Before coring could resume, the metal hardware debris, "junk," had to be removed from the bottom of the hole. The first attempt at retrieving the junk was made with a fishing assembly including a Bowen 9 inch fishing magnet (Fig. F19I, F19K) coupled to a tandem set of junk baskets. This assembly was run in with two stands of drill collars, reentering Hole 1256D for the tenth time at 1815 h on 7 May 2011. The fishing assembly was run in without incident to 1295 mbsf, where it contacted a ledge. The top drive was picked up, and the assembly was advanced to within $73 \mathrm{~m}$ of the bottom ( 1434 mbsf), where circulation was lost. All attempts at unblocking the flow path by varying the pump strokes and running pressures as high as 2500 psi with 20 strokes/min were unable to clear the blockage. Because it would be reckless to attempt to advance any further down the hole without circulation, the drill string was recovered. The magnet, both junk baskets, and the bit sub were packed with sand-sized basaltic cuttings mixed with metal shavings and some cement cuttings (Fig. F19J). This material apparently worked past the float valve during periods of low fluid flow and circulation breaks while making pipe connections. The consensus was that the lower section of the hole needed to be cleaned out to within a couple of meters of the wreckage before a mill or magnet could be effective.

\section{Run 11}

The next cleaning/reaming attempt was made with a used Atlas tricone bit (IADC type 517), a tandem set of external junk baskets (EXJBs), and three stands of drill collars. The assembly reentered Hole $1256 \mathrm{D}$ at $0315 \mathrm{~h}$ on 9 May 2011. The hole was washed, reamed, and heavily flushed with large-volume, high-viscosity mud sweeps. Special attention was given to reaming and washing the ledges found at 1356 mbsf, from 1459 to $1478 \mathrm{mbsf}$, and at 1520 mbsf. The bit cleared the seafloor at $0605 \mathrm{~h}$ and the rotary table at $1130 \mathrm{~h}$ on 10 May. The surface of the reentry cone was flushed prior to withdrawal from the hole. The two EXJBs were found to contain material ranging from fine gravel to cobble-size rocks (Fig. F19L, F19M).

\section{Run 12}

The next fishing attempt was made with a 93/4 inch Bowen full-flow reverse circulation junk basket (RCJB) (Fig. F19N, F19O). The principle of reverse circulation increases the chance of recovery of bit cones, tong pins, hammers, and similar debris. The circulating fluid is jetted outward and downward against the full circumference of the hole, where it is deflected and directs loose objects into the long hollow barrel of the basket. The unit is activated by dropping a stainless steel ball from the surface (Fig. F19S) and does not utilize a float shoe. The RCJB with a Type B mill was made up to a single EXJB and a six-drill collar BHA and deployed at $1300 \mathrm{~h}$ on 10 May 2011. The assembly reentered Hole $1256 \mathrm{D}$ at $2330 \mathrm{~h}$. After the slow circulating parameters were obtained and the hole was flushed with a $100 \mathrm{bbl}$ high-viscosity sweep, the stainless steel activation ball was dropped into the open pipe and the tool lowered to within $1 \mathrm{~m}$ of the bottom ( 1516 mbsf). Because of the high pump rates and resulting standpipe pressure employed, the landing of the ball in the RCJB was not immediately obvious. The tool was worked for $30 \mathrm{~min}$ before the drill string was recovered. On the surface, all five $81 / 4$ inch drill collars were found to be filled with fine hole cuttings weighing on the order of a few hundred kilograms (Fig. F19P). Coarser gravel was also found in the lower part of the BHA in the head sub, crossover subs, and bit subs. The RCJB basket (Fig. F19Q, F19R) contained an array of granoblastic dike rocks with 20 pieces weighing $>100 \mathrm{~g}$. One specimen was $20 \mathrm{~cm} \times$ $10 \mathrm{~cm} \times 10 \mathrm{~cm}$ and weighed $4.5 \mathrm{~kg}$. The total weight of all rocks in the basket was estimated at $\sim 20 \mathrm{~kg}$. The large rocks were assumed to be covering whatever remains of the bit cones, bit legs, and core guides at the bottom of the hole.

\section{Run 13}

The second deployment of the Bowen RCJB was made with a Type A mill shoe and reentered Hole 1256D at $1335 \mathrm{~h}$ on 12 May 2011. The tool was run in the hole to $1385 \mathrm{mbsf}$, where the top drive was picked up. The assembly was carefully advanced with rotation and circulation and tagged a hard 
ledge at 1518 mbsf but was unable to advance past this depth. The steel ball was dropped, but activation of reverse circulation was obscured by pump pressure as high as $3000 \mathrm{psi}$ at $50 \mathrm{spm}$. The drill string was recovered, with the RCJB clearing the top of the cone at $0340 \mathrm{~h}$ on 13 May. Once on the surface, the BHA was again found filled with fine cuttings with a volume comparable to the previous run (Fig. F19T). The RCJB basket contained two rocks with a total weight of $4.5 \mathrm{~kg}$. The RCJB was cleaned, dressed, and laid down.

\section{Run 14}

The fourth fishing attempt was made with a $91 \frac{1}{2}$ inch Homco flow-through junk basket (FTJB) (Fig. F19U). The FTJB does not employ reverse circulation and has a deeper throat than the RCJB. The FTJB is also deployed with a float shoe that reduces the potential for inadvertent filling of the inside of the BHA with cuttings. The fishing assembly entered the reentry cone at $2315 \mathrm{~h}$ on 13 May 2011 and was run in to $1521 \mathrm{mbsf}$ by $0815 \mathrm{~h}$. The driller slowly worked the tool on bottom for 30 min before pulling back. Mud flushes totaling $300 \mathrm{bbl}$ were circulated during this process. The drill string cleared the seafloor at 1345 $h$ and was recovered by $2015 \mathrm{~h}$ on 14 May. The FTJB contained two rocks of granoblastic dike origin that weighed a combined $3.2 \mathrm{~kg}$. Of the two sets of junk catcher fingers, the lower set was completely devoid of fingers (Fig. F19V). Although the FTJB completed the trip to the bottom of the hole, only a fraction of the material snared by the tool was apparently captured.

\section{Run 15}

After reviewing the available options, it was decided that the best way to proceed was to reenter the hole with a hard-formation tricone drilling assembly and attempt to grind away the $\sim 2 \mathrm{~m}$ of hard fill presumably overlying the metal debris of the failed core bit. Once the hard fill was removed, the metal debris could be milled down or possibly recovered by the fishing magnet. Given the persistence of cobblesized material near the bottom of the hole, indicated by the contents of the RCJB of Run 14, a new Smith 7JS tricone bit was picked up and fitted with 3X15 nozzles and affixed to a three-stand BHA with the goal of grinding up the remaining loose rock. The drilling assembly reentered Hole $1256 \mathrm{D}$ at $0730 \mathrm{~h}$ on 15 May 2011. Hard contact was made at 1518.8 mbsf. From 1415 h on 15 May until 0615 on 16 May the hole was washed and reamed from 1518.5 to $1521.1 \mathrm{mbsf}$ and flushed with $460 \mathrm{bbl}$ of high-viscosity mud sweeps. (Note: the precision of these depths is $\pm 1 \mathrm{~m}$, as high tides at Site 1256 precluded accurate determination of the bit depth.) The bit was tripped to the surface after 14.5 rotating hours to ascertain the condition of the bit and assess the progress. The bit cleared the seafloor at $1015 \mathrm{~h}$ and the rotary table at $1545 \mathrm{~h}$ on 16 May. The cones exhibited virtually no wear except for a chipped insert on the gauge cutter. The bearings were tight with some apparent shirttail wear and minor junk damage present on the bit body (Fig. F19Y). These were characteristics of a bit that had done very little actual drilling. When the bit diameter was measured, it was found to be under gauge by $7 / 16$ inches (Fig. F19W). Apparently the bit had been literally squeezed into a smaller diameter hole $(<10$ inches in diameter). The conclusion was that the bottom $\sim 3 \mathrm{~m}$ of the hole was considerably undersized and would have to be reamed to full gauge before fishing could resume. One of the EXJBs was significantly damaged (Fig. F19X).

\section{Run 16}

The sixth tricone bit used during the expedition was selected based less on cutting structure and more on the amount of armor on the legs, because that would be the area that would receive most of the wear during reaming. A Smith FH3VPS 97/8 inch tricone was made up to a three-stand BHA without external junk baskets. The bit reentered Hole 1256D for the sixteenth time of the expedition at $0245 \mathrm{~h}$ on 17 May 2011. By $0815 \mathrm{~h}$, washing and reaming operations began. The undergauge section of the hole ranging from 1516.5 to 1519.7 mbsf was reamed for 15 rotating hours and flushed with a total of $260 \mathrm{bbl}$ of highviscosity sepiolite sweeps. The bit was pulled clear of the seafloor at $0340 \mathrm{~h}$ on 18 May and recovered at $0900 \mathrm{~h}$. The tricone bit was found to be in gauge. Although the tricone was missing six teeth on the middle row of one cone, it was in reasonably good condition (Fig. F19Z, F19AA). The missing teeth suggested that cone contact might have been made with debris at the bottom of the hole. During the reaming, care was taken to avoid penetrating below 1520 mbsf to prevent metal to metal contact with the RCB bit wreckage and avoid potentially leaving more junk in the hole.

\section{Run 17}

Once the reaming was concluded, a flat-bottomed 978 inch mill was made up to the three-stand BHA with a bit sub junk basket (BSJB) and deployed. The mill entered Hole 1256D at 1850 h on 18 May 2011 and initiated milling at $0130 \mathrm{~h}$ on 19 May. Shortly after reentering the cone for the seventeenth time during the expedition, the total length of drill pipe tripped during the cruise passed 100 miles. This milestone was acknowledged by a message of thanks 
to the Transocean teams from the Shipboard Science Party. Milling at a depth of 1520-1521 mbsf progressed without incident until $1330 \mathrm{~h}$. The driller frequently picked up the tool a little off bottom and decreased the pump pressure to let cuttings settle and be captured in the EXJB. This is referred to as "working the junk baskets." A total of $300 \mathrm{bbl}$ of mud was circulated to flush the hole during milling. The mill cleared the seafloor at $1920 \mathrm{~h}$ on 19 May and was recovered by $0315 \mathrm{~h}$ the next morning. The trip out of the hole was suspended for $1.5 \mathrm{~h}$ for the sixth slipping and cutting of the drilling line. The abrasive hard surface on the face of the mill was completely worn away, and the diameter of the tool was under gauge by 0.5 inches (Fig. F19BB). The BSJB was also found damaged (Fig. F19CC).

\section{Run 18}

The second milling tool run was made with a 9 inch flat-bottom mill (Fig. F19DD), which reentered the hole at $1415 \mathrm{~h}$ on 20 May 2011 for the eighteenth time. From 1945 h until 0145 h on 21 May the bottom of the hole was milled and the junk basket worked. Based on the excessive wear to the first milling tool, the rotating time for the second mill run was scaled down from $12 \mathrm{~h}$ to $6 \mathrm{~h}$. A total of $320 \mathrm{bbl}$ of sepiolite mud was circulated to keep the hole clean. The drill string was pulled free of the seafloor at $0645 \mathrm{~h}$, and the second milling tool was secured on deck at $1225 \mathrm{~h}$ on 21 May. The milling surface was abraded clean, and some minor junk damage was noted on the side of the mill (Fig. F19FF). There was also a 3 inch, $200^{\circ}$ circumferential grove cut into the crossover sub located just above the mill. The BSJB was unloaded and found damaged (Fig. F19EE). It contained the usual small cuttings and gravel with some small fresh cuttings of metal. This was the first suggestion that we had finally started to mill bit debris.

\section{Run 19}

The next fishing attempt was made with the third deployment of the RCJB (Fig. F19GG), together with two EXJBs and one BSJB (Fig. F19HH). This assembly reentered Hole $1256 \mathrm{D}$ at $2230 \mathrm{~h}$, on Run 19 of the expedition. The tool was run to $\sim 3 \mathrm{~m}$ off bottom and the junk baskets worked for $\sim 10$ min with pump strokes as high as $150 \mathrm{spm}$ and standpipe pressure reaching 1850 psi. Following a $100 \mathrm{bbl}$ mud flush, the RCJB was worked to the bottom ( 1521 mbsf) with minimum rotation and very light weight on bit. The string was pulled out of the hole, clearing the seafloor at $1015 \mathrm{~h}$ and the rotary table at $1645 \mathrm{~h}$ on 22 May 2011. The RCJB was filled with congealed sepiolite in which were four large rocks with a total weight of $8.9 \mathrm{~kg}$ (Fig. F19II). The largest sample weighed $3.9 \mathrm{~kg}$. The external junk baskets contained fine cuttings, small pebbles, and a few tiny metal fragments.

\section{Run 20}

The RCJB was rebuilt and deployed for the fourth time of the expedition along with the three junk baskets and reentered Hole 1256D at $0635 \mathrm{~h}$ on 23 May 2011 for the twentieth time on this expedition. The trip in was extended for $3 \mathrm{~h}$ while the drill crew repaired the pneumatic control lines for the high clutch in the drawworks. Following the routine of working the junk baskets and flushing the hole with $100 \mathrm{bbl}$ of sepiolite mud, the RCJB was activated and advanced to the bottom of the hole at $\sim 1521 \mathrm{mbsf}$. The RCJB assembly was pulled free of the seafloor at $1725 \mathrm{~h}$ on 23 May and recovered on deck by $0215 \mathrm{~h}$ on 24 May. The RCJB (Fig. F19JJ) contained three rocks with a total weight of $5.0 \mathrm{~kg}$. The angularity of the rocks indicated that they were freshly deposited with a suspected origin somewhere in the bottommost $7 \mathrm{~m}$ of the hole. One rock $(1.4 \mathrm{~kg})$ was a gabbro, suggesting that the "promised land" might be tantalizingly close. The junk basket contained the usual suspects, ranging from gravel-sized cuttings to small pebbles with a few metal filings distributed throughout.

\section{Run 21}

The fifth and last RCJB run of the expedition was deployed with the three junk baskets at $0545 \mathrm{~h}$ on 24 May 2011. The tool entered the reentry cone at 1115 $\mathrm{h}$ for the twenty-first reentry of the expedition. After working the junk baskets and circulating $100 \mathrm{bbl}$ of sepiolite mud, the RCJB was activated and succeeded in reaching the bottom of the hole at $\sim 1521$ mbsf. The RCJB was retracted at $1845 \mathrm{~h}$ and the bottom of the hole displaced with $200 \mathrm{bbl}$ of drill water for logging purposes. The RCJB cleared the seafloor at 0100 $\mathrm{h}$ following a $1 \mathrm{~h}$ interruption to replace a damaged cam roller on the dual elevator handling system. The drill string was recovered at $0700 \mathrm{~h}$ on 25 May. The junk baskets contained the usual collection of fine cuttings and small gravel. The RCJB contained four small rocks. The trend of the progressively smallersized rocks and lighter yield for each succeeding run of the RCJB indicated that the rubble pile at the bottom of the hole had been successfully removed. However, the lack of significant metal in all junk basket runs was perplexing. It was decided to delay the start of the logging program and attempt to recover any metal debris at the bottom using the fishing magnet. 


\section{Run 22}

The 9 inch Bowen fishing magnet was made up along with two EXJBs and one BSJB and deployed. The fishing assembly entered Hole $1256 \mathrm{D}$ at $1645 \mathrm{~h}$ on 25 May 2011. After working the junk baskets and fishing magnet at the bottom of the hole for $30 \mathrm{~min}$, another $200 \mathrm{bbl}$ of drill water was pumped into the bottom of the hole. The routine $100 \mathrm{bbl}$ mud sweep was omitted to save time. The fishing magnet cleared the seafloor at $0230 \mathrm{~h}$ on 26 May and was on deck at $0900 \mathrm{~h}$. The junk baskets contained the routine assorted samples of cuttings and pebbles. The magnet contained only small filings and minor amount of metal (Fig. F19KK).

\section{Logging (26-28 May 2011) Run 23}

A lightweight logging assembly was made up comprising a $9 \frac{1}{2}$ inch logging bit, a landing saver sub, a controlled length drill collar, a tapered drill collar, five transition joints of $5 \frac{1}{2}$ inch drill pipe, and a crossover sub. The logging assembly entered the cone at 1725 h on 26 May 2011 for the twenty-third reentry of the expedition. The bit was placed at a depth of 218.9 mbsf.

The first log was the triple combo (see "Downhole logging" and Fig. F29, both in the "Methods" chapter [Expedition 335 Scientists, 2012b]), which was deployed into the pipe at $2255 \mathrm{~h}$ and recovered at $0700 \mathrm{~h}$ on 27 May. The tool successfully reached the bottom of the hole, although the caliper did not open until $\sim 1490$ mbsf. The bottom of the hole, not logged during Expedition 312, was logged using standard procedures up to $\sim 1300$ mbsf. A caliper log for the rest of the hole right up into the rat hole was measured to assist planning of cementing operations at the end of the cruise. The triple combo tool returned with three damaged bowsprings on the upper centralizer (Fig. F19LL), and these were replaced in preparation for the second scheduled logging run with the FMS-sonic tool.

The FMS-sonic tool string was initially deployed into the pipe at $1050 \mathrm{~h}$ but had to be retrieved at $1410 \mathrm{~h}$ when it was unable to exit the BHA into the borehole because of some mechanical obstruction at the bit. Once on the surface, one damaged bowspring of the lower centralizer was replaced in preparation for the second run. The FMS-sonic was redeployed at $1500 \mathrm{~h}$ and again experienced difficulty exiting the BHA. On this occasion the tool became irretrievably stuck while partially outside the pipe (Fig. F19MM). The Kinley crimping and cutting tool had to be utilized to sever the logging cable. The loose end of the logging cable was recovered at $0330 \mathrm{~h}$ and secured.
The BHA with $\sim 20 \mathrm{~m}$ of logging tool extending below the logging bit was carefully withdrawn from the reentry cone at $0425 \mathrm{~h}$.

\section{Coring and Cementing (28-30 May 2011) Run 24}

After the BHA was recovered and the FMS-sonic centralizer extracted from the landing saver sub (Fig. F19MM), a three-stand RCB coring assembly was made up with a new Ulterra 97/8 inch RCB bit (Fig. F19NN). The last activity of the expedition was to run in with the RCB assembly and deposit cement plugs at the bottom of the hole and from 910 to 940 mbsf. Before pumping the cement, it was decided to core the bottom of the hole until the core bit debris left on 6 May stopped progress or the little time remaining expired, whichever came first.

The RCB assembly entered the reentry cone for the twenty-fourth time of the expedition at $2225 \mathrm{~h}$ on 28 May 2011. A fresh core barrel was deployed at $0515 \mathrm{~h}$ on 29 May, and by $0545 \mathrm{~h}$ coring resumed in Hole $1256 \mathrm{D}$. The core barrel was recovered after advancing from 1520.2 to 1521.6 mbsf. The nominal recovery for the $1.4 \mathrm{~m}$ advance was $0.5 \mathrm{~m}(36 \%)$ and consisted of 10 large pebbles (Core 335-1256D-239R) (Table T4). The average ROP was $0.6 \mathrm{~m} / \mathrm{h}$. The total average recovery for the $14.5 \mathrm{~m}$ of coring during this expedition was $11 \%$. There was no metal in the core barrel or signs of junk in the coring process. This, together with the absence of significant metal debris recovered by the fishing magnet during Run 22, was taken as an indication that metal debris had possibly been mostly ground during Run 9 , shortly after the failure of the C9 coring bit, and that the hole is now likely clean of significant metal junk.

The cleaning of junk and drill cuttings from Hole $1256 \mathrm{D}$ was facilitated by the use of unprecedented amounts of drilling muds (almost 120 short tons; Table T8). The Expedition 309/312 Operations Review Task Force had recommended that the JOIDES Resolution be stocked with at least 60T of sepiolite and attapulgite for use on Expedition 335; almost twice this amount of mud was used to flush cuttings from Hole 1256D.

Time for coring had expired, and cementing operations began at noon. The first cement plug was placed at 1521 mbsf (15 bbl), and the second plug was placed from $~ 940$ to $910 \mathrm{mbsf}(60 \mathrm{bbl})$. These plugs will help stabilize the two problem regions in the hole and facilitate return to the bottom of the hole and coring on a future return to Hole 1256D. The C9 bit used for the last run of Expedition 335 returned to the rig floor in relatively good condition and nearly in gauge (Fig. F1900). A few teeth were 
missing (Fig. F19PP) and the shirttails were worn, with abrasion marks (Fig. F19QQ) much smaller than those caused by metal junk observed during Expedition 312 (Fig. F19RR).

\section{Observations of highly out-of-gauge interval (920-960 mbsf)}

This section summarizes geological and wireline knowledge regarding the problematic region between 920 and 960 mbsf in Hole 1256D that impeded the progress of the drill string to the full depth of the hole on both Expeditions 312 and 335. It seems prudent to collate geological and engineering information on this trouble spot to inform future drilling operations in Hole 1256D. Figure F20 summarizes the stratigraphy of Hole 1256D following operations during Leg 206 and Expedition 309/312. Attention is drawn to the caliper log for the hole. Throughout the lava sequences, the hole diameter is strongly out of gauge between 25 and $50 \mathrm{~cm}$ (10 and 20 inches) diameter, reflecting the fractured nature of the formation and continued erosion resulting from numerous pipe trips through the lava horizons. Although there is an out-of-gauge interval at the bottom of the transition zone (from 1050 to $1060 \mathrm{mbsf}$ ), as of the end of Expedition 312 the hole through the sheeted dike and uppermost plutonic complexes is close to expected gauge. The changing caliper of the borehole is well illustrated in Figure F21, which shows the deviation of Hole 1256D ( $60 \mathrm{~m}$ due west at $1400 \mathrm{mbsf}$ ). The large caliper of the hole at the bottom of the lava sequences is clearly visible. Figure F22 presents the series of caliper logs from 900 to 1000 mbsf successively recorded during Expeditions 309/312 and 335.

Hole blockages were encountered in Hole $1256 \mathrm{D}$ in the interval from 920 to 960 mbsf during the initial reentries during both Expeditions 312 and 335, which prevented the transit of the drill string to the bottom of the hole. Difficult hole conditions were not expected during Expedition 312, which occurred only 2 months after the successful deepening of Hole $1256 \mathrm{D}$ to 1257 mbsf during Expedition 309. On reentering Hole 1256D, the drill string advanced without incident until resistance at 927 mbsf prevented further progress. Approximately 5 days of Expedition 312 were spent reaming and cleaning the interval from 927 to 1051 mbsf, with the region of the hole from 927 to 944 mbsf being very tight and receiving the most attention.

The initial reentry into Hole 1256D during Expedition 335 was impeded by an obstruction at $\sim 922$ mbsf. A total of 15 days were then spent clearing this obstruction, stabilizing the zone from 910 to 960 mbsf, and cleaning and reaming the hole to its full depth (1507 mbsf at the end of Expedition 312).

\section{Expedition 309 coring operations for the interval from $\mathbf{9 0 0}$ to $\mathbf{9 8 0} \mathbf{m b s f}$}

Coring operations between $\sim 897$ and 980 mbsf (Cores 309-1256D-97R through 111R) are briefly reviewed herein. The interval from 897.8 to 958.8 mbsf (4543.2 to 4604.2 mbrf) was drilled without incident during Expedition 309, with moderate recovery (24.3\%) and a ROP of $1.15 \mathrm{~m} / \mathrm{h}$ (RCB Bit 3) (Fig. F23). Before coring commenced with the next bit, a bottom seawater sample was taken with the WSTP. The hole was then reentered and reamed from 868.6 mbsf ( $4514 \mathrm{mbrf}$ ) to the bottom, clearing $\sim 4 \mathrm{~m}$ of fill at the bottom of the hole. Coring continued without incident to $974.4 \mathrm{mbsf}$ with a ROP of $1.14 \mathrm{~m} / \mathrm{h}$ and good recovery (46.7\%) (4619.8 mbrf), until a drop in standpipe pressure following the retrieval of Cores 309-1256D-110R and 111R alerted the drillers to major damage of the bit sub (see the Operations section in Expedition 309/312 Scientists, 2006). The only operational irregularities apparent in the coring of this interval during Expedition 309 was that two cores (309-1256D-101R and 102R) were cored as $9 \mathrm{~m}$ advances as opposed to $\sim 4.8 \mathrm{~m}$ half-cores that had been the standard advance since Core 309-1256D90R. However, these longer advances were not drilled at high rates of recovery as might have occurred if these increased advances had encountered softer formations (e.g., hyaloclastite, flow-top breccia).

The rocks recovered in this interval are predominantly aphyric microcrystalline to fine-grained basalt sheet and massive flows (Fig. F23). Rare volcanic glass, chilled margins, breccia, and altered hyaloclastite were recovered. The lavas are only slightly altered, but there are very common 0.1 to $1 \mathrm{~mm}$ saponite \pm pyrite veins with minor silica and chalcopyrite and rare celadonite, iron oxyhydroxides, and carbonate. Saponite veins are commonly flanked by $<5$ $\mathrm{mm}$ black halos and rarely by green-gray or brown halos. These observations are consistent with a fractured and potential fragile formation. However, the rocks recovered are not especially different from any other parts of the lava sequences. A possible interpretation of the problems encountered in this area at the beginning of Expedition 335, tentatively sketched in Figure F24, is that a slab of a massive lava flow surrounded by more fractured intervals detached and partially obstructed the hole, wedging the BHA against the wall. This situation would explain the strong overpull required to free the pipe when it got stuck in this interval (Table T3). 
Wireline geophysical logs clearly identify this interval between 920 and 960 mbsf, which exhibits outof-gauge caliper and low resistivity. Temperature measured by the wireline tools following the conclusion of drilling operations during Expeditions 309/ 312 and 335 display clear negative excursions (Figs. F11, F23). This suggests that, within this zone, the incursion of cold drilling fluid occurs during coring and cleaning operations, and this incursion inhibits the recovery of this section back to thermal equilibrium following the conclusion of drill fluid pumping.

\section{Principal results}

Hole opening, remediation operations, and the comprehensive destruction of a C9 hard formation coring bit resulted in a major loss of time from the coring and wireline activities planned for Expedition 335. Coring during this expedition deepened Hole 1256D only modestly, from 1507.1 to $1521.6 \mathrm{mbsf}$ (Cores 335-1256D-235R through 239R), at low rates of penetration $(0.9 \mathrm{~m} / \mathrm{h}$ ) and recovery $(11 \%)$ (Table T2; Fig. F25). However, the availability onboard of the Expedition 312 archive- and working-half sections from the lowermost granoblastic dikes and the plutonic section of Hole 1256D (Table T5; Fig. F26) allowed the detailed redescription of these cores and some discrete sample measurements during the extended first phase of hole cleaning. Further fishing and hole cleaning operations at the bottom of Hole $1256 \mathrm{D}$, particularly those runs that deployed the RCJB (Runs 12, 13, 19, 20, and 21) (Table T3) brought back a unique collection of large cobbles (as heavy as $4.5 \mathrm{~kg}$; e.g., 335-1256D-Run 12-RCJB-RockA), angular rubble, and fine cuttings of principally strongly to completely recrystallized granoblastic basalt with minor gabbroic rocks and evolved plutonic rocks (Table T6). The large blocks exhibit intrusive structural and textural relationships and overprinting and crosscutting hydrothermal alteration and metamorphic paragenetic sequences that hitherto have not been observed because of the one-dimensional nature of drill cores and the very low rates of recovery $(<7 \%)$ of the granoblastic dikes during Expedition 312 . Some of the rubble and $\sim 30 \%$ of the fine cuttings recovered by fishing and cleaning operations clearly came from the lava sequences at the top of the hole on the basis of igneous textures and low-temperature alteration minerals ( $\mathrm{Mg}$ saponite and amorphous silica). These rocks will not be described further. In contrast, the high extent of metamorphic recrystallization exhibited by the granoblastic basalts, along with operational factors (e.g., pipe movements), provide strong evidence that the granoblastic basalt, minor gabbros, and evolved plutonic rocks were sourced from the lowermost reaches of Hole 1256D (1494.9-1521.6 mbsf), most probably from below Gabbro 2. Hence, the rocks recovered during Expedition 335 represent a $\sim 15 \mathrm{~m}$ interval of the upper crust-lower crust transition, occurring below the $\sim 90 \mathrm{~m}$ section, recovered during Expedition 312, of two gabbroic bodies (Gabbro 1 and Gabbro 2) separated by Dike Screen 1 (see Fig. F8 in the "Site 1256" chapter [Expedition 335 Scientists, 2012c]).

\section{Igneous petrology}

The interval sampled during Expedition 335 comprises predominantly fine-grained granoblastic aphyric basalt. Although all samples have granoblastic textures (Fig. F27), indicative of high-temperature metamorphism, the degree of recrystallization varies, with strongly recrystallized rocks dominant over completely recrystallized rocks. Some samples preserve dike/dike contacts, and many preserve cores of former plagioclase (micro)phenocrysts (Fig. F27), indicating that the granoblastic rocks represent a metamorphosed sheeted dike complex. This interval has been designated Dike Screen 2 (Figs. F26, F28).

Approximately half of the granoblastic basalts contain small, irregular patches $(<5 \mathrm{~cm} \times 3 \mathrm{~cm})$, veins ( 1-2 mm wide), and dikelets $(<1.5 \mathrm{~cm}$ wide) of evolved plutonic rocks (oxide gabbro, diorite, and tonalite) (Fig. F29A, F29B). The veins are observed to be offshoots of the igneous patches, and diffuse patches are issued from the dikelets. These two observations indicate that the igneous veins, dikelets, and patches form part of the same network, marking a single generation of intrusion of melts into the granoblastic basalts. Their magmatic textures (subhedral to euhedral shapes of several phases, along with poikilitic textures) contrast strongly with the granoblastic textures of the host rocks, demonstrating that intrusion occurred after the granoblastic recrystallization of the host rock. The ubiquitous occurrence of primary magmatic amphibole in the veins and patches suggests high water activities during their formation. Moreover, the presence of quartz, as well as accessory apatite and zircon, implies that the patches, veins, and dikelets crystallized from highly evolved melts.

A small number of gabbroic rocks were recovered (Fig. F29C); the rocks range in composition from disseminated oxide gabbro to orthopyroxene-bearing olivine gabbro. Expedition 335 gabbroic rocks have a more "salt and pepper," equigranular appearance and less textural variability compared to the gabbroic rocks recovered during Expedition 312 (Fig. F29C). Hence, although the contact relationships with the granoblastic basalts were not recovered, it is 
likely that at least some of the gabbroic rocks occur intercalated with the granoblastic basalt, perhaps forming small intrusions.

Overall, a picture emerges of a section of metamorphosed, granoblastic sheeted dikes that underwent small-scale intrusion by both gabbroic and evolved plutonic rocks (Fig. F30).

\section{Geochemistry}

Only a limited number of whole-rock geochemical analyses were undertaken during Expedition 335 (Fig. F31). Major and trace element and volatile concentrations were determined on three granoblastic basalts from Cores 335-1256D-235R through 238R, on one basalt lava, and on five granoblastic basalt and two gabbroic rocks recovered during junk basket runs. These samples were chosen from the least altered parts of the core and rock samples and as far as possible from hydrothermal veins and magmatic intrusions to obtain the best estimate of primary compositions.

The basalt and granoblastic dikes have normal midocean-ridge basalt (N-MORB) compositions similar to that of the variably altered basaltic lavas, dikes, and granoblastic dikes cored in the overlying crust in Hole 1256D (e.g., Teagle, Alt, Umino, Miyashita, Banerjee, Wilson, and the Expedition 309/312 Scientists, 2006). The two gabbros (olivine gabbronorite and olivine gabbro) have high loss on ignition (LOI) ( 1.5-2 wt $\%)$, consistent with those samples being more affected by hydrothermal alteration processes than the neighboring granoblastic basalts. The gabbros are also quite distinct from the granoblastic dikes with respect to major and trace element concentrations. Expedition 335 gabbro compositions are typical of gabbroic cumulate suites sampled in oceanic environments but are also similar to those of the less evolved members of Gabbro 1 previously sampled in Hole 1256D. However, they are more primitive than any analysis from Gabbro 2. Expedition 335 gabbroic rocks have relatively high $\mathrm{MgO}$ $(\sim 12 \mathrm{wt} \%)$ and $\mathrm{Ni}(\sim 300 \mathrm{ppm})$ concentrations but low concentrations of incompatible trace elements compared to granoblastic dikes (Fig. F31). The relatively high Mg\# (70-72) and Ni concentrations of the Expedition 335 gabbros principally reflect their modal olivine contents.

One characteristic of the granoblastic basalts sampled during Expedition 335 is relatively low concentrations of $\mathrm{Cu}, \mathrm{Zn}, \mathrm{Zr}$, and $\mathrm{Y}$ compared to previously sampled basaltic samples in Hole 1256D (Fig. F31). Compared to all granoblastic and sheeted dike analyses, the Expedition 335 granoblastic basalt yields the most depleted compositions for these elements.
The lower part of Hole 1256D, below 1340 mbsf, is characterized by strong chemical variations, with $\mathrm{Mg \#}$ ranging from 42 to $72 \mathrm{ppm}$ and $\mathrm{Zr}$ from 23 to $117 \mathrm{ppm}$. These changes in composition mainly reflect the changes in rock types from the low Mg\#, incompatible trace element-rich sheeted dikes and granoblastic dikes to the higher Mg\# and incompatible trace element-depleted gabbroic rocks of Gabbro 1 and Gabbro 2. There is a general downhole trend of decreasing incompatible element (e.g., $\mathrm{Zr}$ and $\mathrm{Y}$ ) contents in the granoblastic dikes (Fig. F31). At a more localized scale, the granoblastic basalt sampled within Dike Screen 1 and below Gabbro 2 in Dike Screen 2 defines trends of increasing $\mathrm{Zr}$ with depth. The lowest $\mathrm{Zr}$ values occur directly at the upper interface between the granoblastic basalt and the overlying gabbroic intrusion. This pattern is particularly marked at the bottom of Hole 1256D, where the most trace element-poor granoblastic basalt of Hole 1256D was sampled at 1502 mbsf, just below Gabbro 2 (Yamazaki et al., 2009). Expedition 335 samples show a near doubling of $\mathrm{Zr}$ contents from $\sim 30 \mathrm{ppm}$ at 1507-1512 mbsf to $58 \mathrm{ppm}$ at 1518 mbsf. These downhole variations in incompatible element contents are mimicked by changes in $\mathrm{Zr} / \mathrm{Y}$, with granoblastic basalt from directly below Gabbro 2 having low $\mathrm{Zr} / \mathrm{Y}(\sim 1.5)$ compared to the sheeted dikes and granoblastic dikes above Gabbro 1 (2-3). We interpret the systematic depletion observed in the granoblastic basalt just below both Gabbro 1 and Gabbro 2 as indicative of small degrees of partial melting, probably caused by gabbroic intrusions into the partially hydrated dikes (e.g., Miyashita et al., 2007; Koepke et al., 2007, 2008). The degree of partial melting is probably minor, as the effects on dike major element compositions are undetectable. We also observe a general decrease in $\mathrm{Cu}$ and $\mathrm{Zn}$ contents in the granoblastic basalt sampled at the bottom of Hole $1256 \mathrm{D}$, consistent with mobilization of $\mathrm{Cu}$ and $\mathrm{Zn}$ by high-temperature hydrothermal alteration $\left(>400^{\circ} \mathrm{C}\right)$. At the bottom of Hole $1256 \mathrm{D}$, low base metal concentrations appear to be a signature of only the granoblastic basalt. This may imply that the intrusion of Gabbro 1 and Gabbro 2 occurred after this stage of high-temperature hydrothermal alteration, consistent with the remelting process suggested by downhole $\mathrm{Zr} / \mathrm{Y}$ variations.

All granoblastic basalt recovered during Expedition 335 has trace element compositions similar to the granoblastic rocks cored directly below Gabbro 2 during Expedition 312 (>1500 mbsf). This is further strong evidence that Expedition 335 granoblastic basalt comes from the lowermost levels of Hole 1256D, probably below 1494 mbsf. 


\section{Alteration and metamorphism}

Rocks recovered during Expedition 335 are mainly dark gray, fine-grained basalt that was recrystallized by contact metamorphism. They are essentially identical to the granoblastic basalt from Dike Screen 1 between Gabbro 1 and Gabbro 2 cored during Expedition 312. Coarser grained plutonic material occurs as separate rock fragments or as $1 \mathrm{~mm}$ to $1 \mathrm{~cm}$ sized dikelets and veins, as well as irregular intrusions into the dike rocks.

Dike Screen 2 basalt is recrystallized to granoblastic assemblages of clinopyroxene, orthopyroxene, plagioclase, magnetite, ilmenite, and rare brown hornblende and quartz, with accessory sulfide minerals (pyrrhotite, chalcopyrite, and pyrite) (Fig. F32). Veins of granoblastic orthopyroxene \pm plagioclase \pm clinopyroxene, 100-200 $\mu \mathrm{m}$ wide, are common and are likely recrystallization products of hydrothermal vein protoliths. Dike samples include a chilled intrusive dike contact and a brecciated intrusive dike margin that were hydrothermally altered and then recrystallized to granoblastic assemblages during contact metamorphism.

The granoblastic rocks typically exhibit at most only slight, post-contact metamorphism, hydrothermal alteration (generally $<15 \%$ ), mainly to amphibole. Clinopyroxene is locally partly altered to amphibole, orthopyroxene is variably altered to amphibole and local talc and smectite, and plagioclase is locally slightly altered to trace chlorite, actinolite, secondary plagioclase, and smectite. Fe-Ti oxides are partly altered to titanite.

The dikes are cut by common $0.1-0.5 \mathrm{~mm}$ thick amphibole veins, with $\sim 1-3 \mathrm{~mm}$ wide amphibole-rich alteration halos. These veins cut across the intrusive dike contact, granoblastic veins, and coarser grained igneous intrusive rocks. Also present are rare later veins containing actinolite, chlorite, quartz, epidote, and prehnite.

Coarser grained rocks (olivine gabbronorite, oxide gabbro, and quartz diorite) are more highly altered, with clinopyroxene highly altered to amphibole + fine magnetite and plagioclase partly altered to secondary plagioclase, amphibole, minor chlorite, and local epidote. Olivine exhibits coronitic alteration to amphibole, talc, magnetite, pyrrhotite, smectite, and rare iron oxyhydroxides. The intruded granoblastic host rocks are commonly highly altered to amphibole for as much as $1 \mathrm{~cm}$ around the intrusions. These observations are consistent with evidence from Expedition 312 that these intrusive boundaries are zones of enhanced fluid flow and fluid-rock exchange.
The cores and rocks recovered during Expedition 335 sample the transition from sheeted dikes to the gabbroic section of oceanic crust. The dikes underwent hydrothermal alteration in a mid-ocean-ridge hydrothermal system at the spreading axis. The altered dikes were then intruded by the two gabbro bodies cored during Expedition 312 and other magmatic bodies near the bottom of the hole and underwent contact metamorphism at temperatures of $\sim 900^{\circ}-$ $1000^{\circ} \mathrm{C}$. The effects of prior hydrothermal alteration influenced the degree of recrystallization. Cooling and fracturing allowed further penetration of fluids and hydrothermal alteration of these rocks, with formation of amphibole veins and later retrograde minerals (actinolite, quartz, epidote, chlorite, prehnite, and late smectite and iron oxyhydroxides).

The granoblastic dikes and underlying dike screens represent the conductive boundary layer between mafic magma and the overlying hydrothermal system, and the rocks from Hole $1256 \mathrm{D}$ are similar to those observed in ophiolites and elsewhere in oceanic crust (e.g., Gillis and Roberts, 1999; Gillis, 2008; France et al., 2009). The granoblastic basalt sampled beneath Gabbro 2 during Expedition 335 is part of a dike screen within the transition from sheeted dikes to gabbros, consistent with the presence of a significant underlying gabbro heat source.

\section{Structural geology}

Cores from the plutonic section drilled during Expedition 312 and cores, cuttings, and cobbles recovered during Expedition 335 contain important crosscutting relationships that illustrate the intimate interplay between magmatic, metamorphic, fluid flow, and brittle deformation processes. Unfortunately, because of the paucity of oriented pieces, many structural investigations could not be completed.

Several vertically oriented Expedition 312 core pieces were tentatively azimuthally reoriented based on paleomagnetic data assuming normal polarity, although this remains to be definitively demonstrated. The reoriented azimuth of the upper contact between the granoblastic dikes and Gabbro 1 and between Dike Screen 1 and Gabbro 2 were (dip/dip direction) $42^{\circ} / 260$ and $81 \% / 255$, respectively. The orientations of the preserved contacts suggest that the gabbro intrusions dip at moderate to steep angles to the west-southwest, toward the paleospreading ridge. Veins from Expedition 312 cores show a bimodal orientation distribution, with a steeply dipping maximum $\left(60^{\circ}\right)$ and a second gently dipping maximum $\left(10^{\circ}\right)$. Using the same reorientation technique as for the contacts, all veins dominantly strike northwest-southeast. It must be kept in mind that there are significant uncertainties in the reliability of 
reorientation of individual structures because of the assumptions made in the reorientation process

A variable fracture density of subhorizontal irregular fractures is thought to be drilling-induced fractures. The boundaries between gabbros and granoblastic basalts have higher fracture densities.

Gabbroic rocks from the Gabbro 1 interval are mineralogically and texturally heterogeneous and commonly display lighter color, leucocratic patches that result from a multistage magmatic history, with the percolation of more evolved melt through a partially crystallized gabbroic mush (Teagle, Alt, Umino, Miyashita, Banerjee, Wilson, and the Expedition 309/ 312 Scientists, 2006). The two-dimensional distribution of these leucocratic patches was quantified using an image analysis technique on high-resolution photographs of the archive halves cut face see "Structural geology" in the "Methods" chapter (Expedition 335 Scientists, 2012b). The shape-preferred orientation of the patches is very weak, and there is no obvious downhole trend. The image analysis also provides an accurate estimate of the modal distribution of the leucocratic patches, which shows some systematic trends downhole, correlated to distinct trends in magnetic susceptibilities, and revealing three possible distinct petrological units. These three zones are characterized by a broad upward increase in percentage of leucocratic patches and are delimited by limits that correspond to unit boundaries defined during Expedition 312 (85/86A) and Expedition 335 (89A/89C).

\section{Paleomagnetism}

Paleomagnetic analyses during Expedition 335 focused predominantly on a detailed investigation of samples from Gabbro 1 and Gabbro 2 because of the lack of vertically oriented core recovered during Expedition 335. New data from shipboard thermal demagnetization experiments on discrete samples prepared during the expedition were augmented by unpublished shore-based data from the interval 1406-1503 mbsf that were analyzed by shipboard paleomagnetists. In addition, new data on the anisotropy of magnetic susceptibility (AMS) were acquired and reoriented using remanence data.

Samples are dominated by a steep, near-vertical drilling-induced remanent magnetization (DIRM) that represents an average of $66 \%$ of the total remanence (Fig. F33). Following removal of the DIRM by low to intermediate demagnetization treatments, shallow to moderate inclination components are typically isolated above $35 \mathrm{mT}$ or $540^{\circ} \mathrm{C}$ and are considered to represent the characteristic remanent magnetization (ChRM) of the samples. The mean inclination of these components is $31^{\circ}$, significantly steeper than that expected for the paleoposition of Site 1256, which restores to an equatorial paleolatitude in the Miocene (Wilson, Teagle, Acton, et al., 2003). Potential causes of this apparent steepening of inclinations include the following:

- Contamination of ChRM components by a residual DIRM persisting to high demagnetization levels. This contamination is, however, unlikely to account fully for the observed data because it would require near complete overlap of the coercivity/unblocking temperature spectra of grains carrying the DIRM and ChRM at high fields/temperatures, and DIRM is predominantly carried by multidomain magnetite (Allerton et al., 1995) with generally low coercivity and distributed unblocking temperatures.

- A present-day field thermoviscous overprint. This overprint is unlikely, given the low ambient temperatures in the section and the high unblocking temperature of ChRMs, and is discounted entirely by the presence of multicomponent remanences in some interval.

- The presence of a persistent nondipole field at Site $1256 \mathrm{D}$ during the Miocene. Little is known about the geometry of the field in the Pacific at $15 \mathrm{Ma}$, but analysis of anomalous skewness of younger marine magnetic anomalies in the Galapagos region (Schneider, 1988) suggests that nondipole field components may account for at most a few degrees of inclination anomaly.

- Tectonic tilting of the section. Tilting of $\sim 10^{\circ}-20^{\circ}$ is compatible with the observed dip of dike margins in the sheeted dike section of Hole 1256D (Teagle, Alt, Umino, Miyashita, Banerjee, Wilson, and the Expedition 309/312 Scientists, 2006; Tominga et al., 2009) and may potentially account for $\sim 10^{\circ}$ of inclination steepening assuming a ridgeparallel rotation axis. Larger amounts of inclination change may be produced by rotation around non-ridge-parallel axes but are difficult to reconcile with the tectonic setting of the section.

- Deflection of remanence directions by a strong anisotropy of consistent orientation. This can result in $\sim 10^{\circ}-20^{\circ}$ of inclination change (depending on the degree of anisotropy and its orientation relative to the remanence). It can only be quantified and assessed by analysis of the anisotropy of remanence (Potter, 2004), which will form a focus of postcruise research.

The new thermal demagnetization data reveal a previously unrecognized type of remanence structure in a sample from Gabbro 2. After removal of steep DIRM by low-temperature (liquid nitrogen) demagnetization, two well-defined intermediate and high 
unblocking temperature components with antipodal directions are identified (Fig. F33). These data represent the first multipolarity remanences seen in lower crustal rocks formed at the EPR and are similar to examples reported recently from sites along the MidAtlantic Ridge (Meurer and Gee, 2002; Morris et al., 2009). Sampling of the gabbroic section conducted during Expedition 335 for further shore-based analyses of these multipolarity remanences will allow their distribution and significance to be determined, potentially leading to new information on the thermal evolution of the section.

AMS tensors from discrete samples from Gabbro 1 and Gabbro 2 are shown to be randomly oriented in the core reference frame (Fig. F34). In the absence of independent reorientation of core pieces via analysis of FMS imagery, a basic, first-order reorientation of these data is possible by applying vertical axis rotations to AMS data to align corresponding ChRM directions to present-day north. This results in a preferred north-south alignment of AMS maximum principal axes. This is particularly apparent in data from samples with prolate (lineated) AMS fabrics and may indicate that a significant along-axis preferred mineral alignment is frozen into the gabbro section. Similar ridge-parallel magnetic lineations have been reported from the slow spreading rate Troodos ophiolite (Abelson et al., 2001) and have been interpreted to indicate along-axis migration of melt. Further detailed postcruise analyses of AMS and other forms of magnetic anisotropy (e.g., anisotropy of anhysteretic remanence) should allow this hypothesis to be tested.

\section{Physical properties}

Physical property measurements during Expedition 335 revealed that the granoblastic basalt samples generally have high magnetic susceptibility $(\sim 6200 \times$ $10^{-5} \mathrm{SI}$ on average) (Fig. F35), whereas gabbroic rocks have lower average magnetic susceptibility $(\sim 3000 \times$ $10^{-5} \mathrm{SI}$ ) but display much larger variation. In the gabbro units, magnetic susceptibility and color reflectance data follow variations in oxide and olivine content (see Fig. F88 in the "Site 1256" chapter [Expedition 335 Scientists, 2012c]). Natural gamma radiation shows peaks that coincide with occurrence of evolved plutonic rocks consistent with relatively high concentrations of $\mathrm{K}, \mathrm{U}, \mathrm{Th}$, and other incompatible elements in these rocks.

A measuring technique using a seawater bath was developed that greatly improved the quality of shipboard $P$-wave velocity measurements of discrete samples see "Physical properties" in the "Methods" chapter (Expedition 335 Scientists, 2012b). The velocities of gabbro range from 6.30 to $6.76 \mathrm{~km} / \mathrm{s}$, whereas measurements of granoblastic basalt range from 6.61 to $6.91 \mathrm{~km} / \mathrm{s}$. These relatively high velocities are consistent with the trends of downhole geophysical logs above 1400 mbsf and may indicate that the lower section of Hole $1256 \mathrm{D}$ is close to the seismic Layer $2 / 3$ boundary (Fig. F36).

\section{Downhole logging}

Because of technical troubles, the triple combo was the only logging tool string deployed during Expedition 335. It recorded the density, porosity, gamma ray emission, and resistivity of the formation, as well as the temperature of the borehole fluid over the entire hole, reaching the maximum depth of 1520 mbsf, $80 \mathrm{~m}$ below the deepest logs recorded at the end of Expedition 312. In addition to measuring the properties of the gabbros and dike screens at the bottom of the hole, one of the objectives of the logging program was to record a full caliper log over the entire hole to assess the results of the previous cementing operations (Figs. F22, F23), to help plan the endof-expedition cementing operations to stabilize Hole 1256D for future expeditions, and to provide information for potentially casing the uppermost part of Hole 1256D.

\section{Logging results}

The hole size (Fig. F37) shows that the bottom was significantly enlarged after several weeks of junk basket runs dedicated to cleaning the hole. The hole is irregular below $\sim 1410 \mathrm{mbsf}$, and the low density and high porosity readings below this depth are a direct consequence of the hole size. The decoupling between the shallow and resistivity logs is also a consequence of the hole size. However, the deepest resistivity measurement should not be affected by hole size and indicates a decrease in resistivity with depth starting below Gabbro 1 ( 1460 mbsf) that becomes more apparent by Gabbro 2. In contrast with the increase with depth expected in the plutonic section, this decrease suggests that the deepest section might be fractured, possibly part of a fault, which could explain some of the difficulties encountered while coring.

\section{Hole size}

Higher up in the hole, hole cleaning and cementing operations around $\sim 920$ mbsf considerably changed the shape of the hole (Fig. F38). Although several days spent trying to pass this interval contributed to enlarge the hole above it, the cement reduced the hole size and its roughness below. Between 930 and 970 mbsf the hole is large but without asperities and should not present any difficulty for future reentries, 
as shown by the 15 smooth reentries following the cementing operation during Run 8.

\section{Temperature logs}

Comparison between the temperature logs recorded by the two temperature tools during Expedition 335 and the temperatures measured during previous expeditions in Hole 1256D (Fig. F39) shows similar trends as the borehole fluid recovers from the disturbance of the drilling operations. Several excursions to lower temperatures, in particular around $925 \mathrm{mbsf}$ and 1060 mbsf, coincide with intervals with lower resistivity, indicating more permeable intervals where the formation might have been invaded by the drilling fluid and is consequently recovering more slowly from the drilling process. The kick at $\sim 1300$ mbsf that was also observed during Expedition 312 coincides with lower resistivity and is probably also associated with fluid exchange with the formation. These anomalies will be the object of numerical modeling, which in combination with other logs should provide estimates of the permeability in these intervals.

\section{Conclusions}

When the textural and contact relationships exhibited by the large rocks recovered from the junk baskets are placed in the geological context of the Hole 1256D stratigraphy, a vision emerges of a complex, dynamic thermal boundary layer zone. This region of the crust between the principally hydrothermal domain of the upper crust and the intrusive magmatic domain of the lower crust is one of evolving geological conditions. There is intimate coupling between temporally and spatially intercalated magmatic, hydrothermal, partial melting, intrusive, metamorphic, and retrograde processes.

With only a minor depth advance in Hole $1256 \mathrm{D}$, we have yet to recover samples of cumulate gabbros required to test models of ocean ridge magmatic accretion and the intensity of hydrothermal cooling at depth. Nor have we crossed the Layer $2 / 3$ boundary at Site 1256 . The total vertical thickness of granoblastic basalts is $>114 \mathrm{~m}$, and Dike Screen 2 is now about the same thickness (so far) as Dike Screen 1. High perched, isolated gabbro intrusions are uncommon in ophiolites. The energy requirements for the granoblastic recrystallization at granulite facies condition of a $>114 \mathrm{~m}$ thick zone of sheeted dikes massively exceeds the thermal capacity of Gabbros 1 and 2 (e.g., Koepke et al., 2008; Coggon et al., 2008) if a simple subhorizontal arrangement of these layers is assumed. The enormous heat requirements for such extensive granulite facies recrystallization, the evidence for partial melting, together with the tantaliz- ing presence of minor but not uncommon gabbroic rocks and felsic intrusive, dikelets, and veins, strongly indicates that the layer of purely plutonic rocks should be at most only a few tens of meters deeper in the hole.

Although the extensive remedial operations on Expedition 335 precluded significant deepening of Hole $1256 \mathrm{D}$, significant progress was made in improving the borehole. The most problematic out-ofgauge zone at $~ 920-960$ mbsf that caused reentry problems during Expeditions 312 and 335 has been stabilized with cement. The bottom of the hole has been cleared of rubble and junk, and there appears to be only a short, slightly undergauge zone $(<1 \mathrm{~m})$. Importantly, the regular large sweeps of high-viscosity mud (as much as $200 \mathrm{bbl}$ sepiolite every $\sim 2 \mathrm{~h}$ ), have finally overcome and expunged the vast amount of fine cuttings recirculating in the hole, some most likely resident since Leg 206. This progress is shown by the absence of soft fill in the final $\sim 5$ reentries compared to $>50 \mathrm{~m}$ of soft fill at the end of Expedition 312. Engineering efforts during Expedition 335 have repaired and prepared Hole $1256 \mathrm{D}$ for further deep drilling, following 5 years of neglect. Hole $1256 \mathrm{D}$ is $1500 \mathrm{~m}$ of hard rock coring closer to cumulate gabbros than any other options in intact ocean crust. It is once more poised to answer fundamental questions about the formation of new crust at fastspreading mid-ocean ridges, best achieved by a timely return to the site.

\section{Preliminary assessment Preliminary scientific assessment}

Expedition 335 was the fourth ocean cruise of the Superfast Spreading Crust campaign to drill a deep hole into intact oceanic basement and returned to Hole $1256 \mathrm{D}$ to deepen this scientific reference penetration a significant distance into cumulate gabbros. Cores and data recovered from the uppermost lower ocean crust and the transition down to cumulate gabbroic rocks would provide hitherto unavailable observations that will test models of the accretion and evolution of the oceanic crust.

Although previous cruises to Hole 1256D (Leg 206 and Expedition 309/312) had achieved the benchmark objective of reaching gabbro in intact ocean crust, critical scientific questions remain. These include the following:

- Does the lower crust form by the recrystallization and subsidence of a high-level magma chamber (gabbro glacier) or crustal accretion by intrusion of sills throughout the lower crust or by some other mechanism? 
- Is the plutonic crust cooled by conduction or hydrothermal circulation?

- What is the geological nature of Layer 3 and the Layer 2/3 boundary at Site 1256?

- What is the magnetic contribution of the lower crust to marine magnetic anomalies?

At the end of Expedition 312 in 2005, Hole 1256D was clear to its full depth and poised to be deepened into intervals where samples that should conclusively address these questions can be obtained, possibly with only a few hundred meters of drilling.

Unfortunately, operational difficulties in Hole $1256 \mathrm{D}$ precluded progress toward the scientific objectives with only $<15 \mathrm{~m}$ of advance achieved in Hole 1256D; the hole now has a total depth of $1521.6 \mathrm{mbsf}$ (1271.6 msb). The bottom of the hole remains hosted by the dike-gabbro transition zone, dominated by granoblastic basalt.

In addition to the few cores drilled, junk baskets deployed during the successive fishing runs to the bottom of the hole recovered a unique collection of samples including large cobbles (as large as $5 \mathrm{~kg}$ ), angular rubble, and fine cuttings of principally strongly to completely recrystallized granoblastic basalt with minor gabbroic rocks and evolved plutonic rocks. The large blocks exhibit structural and textural relationships, metamorphic paragenetic sequences, and overprinting hydrothermal alteration, which hitherto have not been observed because of the narrow diameter of drill cores and the very low recovery of the granoblastic basalts cored so far.

Including the $\sim 60 \mathrm{~m}$ thick zone of granoblastic dikes that reside above the uppermost gabbros, the dikegabbro transition zone at Site 1256 is $>170 \mathrm{~m}$ thick, of which $>100 \mathrm{~m}$ is recrystallized granoblastic basalt. This zone records a dynamically evolving complex thermal boundary layer between the principally hydrothermal domain of the upper crust and the intrusive magmatic domain of the lower crust. An intimate coupling between temporally and spatially intercalated magmatic, hydrothermal, partial melting, intrusive, metamorphic, and retrograde processes is recorded in the samples recovered, which will be subjected to a comprehensive suite of postcruise petrologic, geochemical, and geophysical studies.

Expedition 335 left Hole 1256D after making only a very modest advance, and we have yet to recover samples of cumulate gabbros required to test models of ocean ridge magmatic accretion and the intensity of hydrothermal cooling at depth. However, the remarkable sample suite of granoblastic basalt samples, with minor gabbros intruding previously recrystallized dikes, provides a detailed picture of a rarely sampled critical interval of the oceanic crust. Most importantly, the hole has been stabilized, cleared to its full depth, and is ready for deepening in the near future.

The archive and working halves of Cores 312-1256D202R through 234R (1372.8-1507.1 mbsf) from the lower part of the granoblastic dikes to the bottom of the hole at $1507.1 \mathrm{mbsf}$, including the plutonic section of Hole 1256D, were shipped to the JOIDES Resolution prior to Expedition 335. These cores were made available to the science party for the purpose of familiarization with the recovered plutonic section of Hole 1256D and to establish and test description protocols during transit to Site 1256 . The scientists also developed the DESClogik configuration for the capture of plutonic rock descriptions for the first time since the introduction of the LIMS database. The long duration of operations required to open Hole $1256 \mathrm{D}$ to its full depth at the beginning of Expedition 335 (see "Operations" $\square \sim 16$ days) provided sufficient time for the 335 Shipboard Science Party to completely redescribe these cores. This was considerably more time than was available to the shipboard scientists at the end of Expedition 312. Some discrete measurements (paleomagnetism and physical properties) were also performed.

A new measuring protocol using a seawater bath was developed onboard that greatly improved the quality of shipboard $P$-wave velocity measurements of discrete samples. The velocities of gabbro range from 6.30 to $6.76 \mathrm{~km} / \mathrm{s}$, whereas measurements of granoblastic basalt range from 6.61 to $6.91 \mathrm{~km} / \mathrm{s}$, as much as $~ 800 \mathrm{~m} / \mathrm{s}$ higher than measurements done under the standard shipboard protocols during Expedition 312 (that are often significantly lower than shorebased laboratory measurements). These high velocities are more consistent with the trends of downhole geophysical logs above 1400 mbsf and may indicate that the lower section of Hole $1256 \mathrm{D}$ is close to the seismic Layer $2 / 3$ boundary.

The engineering efforts during Expedition 335 (see "Preliminary operational assessment") have repaired and prepared Hole 1256D for further deep drilling, following 5 years of neglect. Hole $1256 \mathrm{D}$ is $1500 \mathrm{~m}$ of hard rock coring closer to cumulate gabbros than any other options in intact ocean crust. The already great thickness of granoblastically recrystallized dikes and the tantalizing presence of minor gabbro bodies strongly suggests that the zone of $100 \%$ plutonic rocks must be close, perhaps only a few tens of meters below the present bottom of the hole. Hole $1256 \mathrm{D}$ is once more poised to answer fundamental questions about the formation of new crust at fast spreading mid-ocean ridges, best achieved by a timely return to the site. 


\section{Preliminary operational assessment}

The principal goal of Expedition 335's return to Hole $1256 \mathrm{D}$ was to deepen the hole sufficiently into plutonic rocks (a few hundred meters) to obtain definitive answers to long-standing questions about the structure and composition of the oceanic crust and about mechanisms of crustal accretion (these ideas are developed in greater detail in "Background and geological setting" and the "Deep drilling of intact ocean crust: harnessing past lessons to inform future endeavors" chapter [Expedition 335 Scientists, 2012a]).

Operational planning for Expedition 335 was informed by three principal sources:

1. The Operations teams' experiences during Leg 206 and Expedition 309/312 to Hole 1256D and previous deep basement coring by scientific ocean drilling;

2. Aspects of the IODP Operations Review Task Force Meeting "Expeditions 309/312 Superfast Spreading Rate Crust" (ORTF-309/312-03, June 2006; see 309_312_ORTF.PDF in REPORTS in "Supplementary material"); and

3. A USIO position paper, "Operational requirements for returning to Hole 1256D" (September 2006; see MOHO_2006.PDF in REPORTS in "Supplementary material").

The recommendations of the Expedition 309/312 Review Task Force indicate an understanding of the nonstandard requirements of deep basement drilling and echo the suggestions made by the Co-Chief Scientists of those expeditions (Teagle, Alt, Umino, Miyashita, Banerjee, Wilson, and the Expedition 309/ 312 Scientists, 2006; see 309_312_COCHIEF.PDF in REPORTS in "Supplementary material"). Three recommendations in the 309/312 OTRF report pertinent to operations during Expedition 335 were

1. To investigate alternate scheduling strategies (e.g., at-sea crew changes and lengthening standard expedition durations to maximize on-site time for deep drilling objectives; Recommendation ORTF-309/312-03),

2. To investigate and prioritize avenues for enhancing coring/drilling capability (particularly of hard formations) for deep-drilling programs (Recommendation ORTF-309/312-11), and

3. To build on the experiences of Phase 1 expeditions and actively explore future applications of drilling muds (particularly those with heavy lifting capability) for riserless hole cleaning and stabilization (Recommendation ORTF-309/31212).

Unfortunately, there has been only modest progress on these recommendations in the 5 years since the
309/312 ORTF meeting, with a half-length expedition initially scheduled by the Science Advisory Structure for the return to Hole 1256D and an absence of new drilling and coring options for hard formations and hole cleaning.

The IODP Science Planning Committee requested in 2006 (SPC Consensus 0603-19) that the USIO identify the operational requirements for further drilling in Hole $1256 \mathrm{D}$. TAMU engineers from the USIO presented their operational plan to an audience of scientists and independent drilling engineers at the Mission Moho Workshop (Portland, Oregon, 7-9 Sept 2006) for technical review. There was consensus support for the plan proposed (see MOHO_2006.PDF in REPORTS in "Supplementary material").

The USIO considered four deepening scenarios:

1. Resume RCB coring in Hole $1256 \mathrm{D}$ using largevolume (100-150 bbl) high-viscosity mud sweeps combined with frequent bit trips,

2. Enlarge the hole to $18 \frac{1}{2}$ inches to isolate the out-of-gauge section using $13 \frac{3}{8} \mathrm{inch}$ casing,

3. Forego $133 / 8$ inch casing and enlarge the hole to $14 \%$ inches to isolate the out-of-gauge section using 103/4 inch casing, and

4. Offset and start a new hole following the casing strategy employed during Leg 206.

Two key points were noted by the USIO and independent engineers at the Mission Moho Workshop:

1. Hole $1256 \mathrm{D}$ is in excellent condition, and remedial engineering operations such as reaming and casing are premature.

2. Neither the offshore industry nor scientific ocean drilling operators have ever attempted to open up an existing deep basement hole to any significant depth (hundreds of meters) in basalt and insert casing.

Regardless of the casing strategy proposed ( 2 or 3 ), attempting to open any portion of Hole $1256 \mathrm{D}$ to accommodate casing would require significant new hardware, numerous pipe trips, and extend over several expeditions. Such operations would require unproven technology and would be extremely challenging with substantial risk of irreparable damage to Hole $1256 \mathrm{D}$ without any further coring or recovery. The USIO and independent experts felt that approaches 2 and 3 are not viable options and recommended that they were not considered further.

The preferred USIO strategy was 1: resuming RCB coring with frequent large-volume high-viscosity mud sweeps (Recommendation ORTF-309/312-12). During Expedition 309/312, large-volume mud sweeps were effective at clearing cuttings from the hole. However, because of the end of Phase I operations, mud stock depletion precluded the vigorous 
implementation of this approach throughout the whole of Expedition 312. The refitted JOIDES Resolution should be equipped to handle the necessary supplies to maintain an aggressive mud program. Following the recommendations of the IODP Expedition 309/312 ORTF, the JOIDES Resolution was stocked with at least $60 \mathrm{~T}$ of sepiolite and attapulgite for use during Expedition 335.

Assuming reasonable hole conditions and an average rate of penetration comparable to previous coring in this hole, TAMU engineers estimated that this approach should deepen Hole 1256D $350 \mathrm{~m}$ with 39 days on site (Teagle et al., 2010). The engineering and design lessons learned from a few hundred meters deeper penetration of intact ocean crust would be invaluable in planning and exploiting future deep penetration targets.

Further deepening of Hole 1256D using large mud sweeps was the only strategy that begins with coring, was the most likely to return samples from deeper in the hole, and had the largest possibility of building on the tremendous success of previous deepening operations on Expedition 309/312 that employed proven drilling techniques.

Before conditioning the hole for further deepening, an attempt would be made to acquire an equilibrium temperature profile and recover a water sample before the thermal structure of the crust is perturbed by cleaning and drilling operations (see next section). We planned to reenter the hole with a tricone drilling bit on a bit release and slowly descend past the zone around 900 mbsf that caused an obstruction during Expedition 312. If the hole was clear, we would withdraw the pipe, drop the bit, and reenter to below the rat hole to allow logging with the triple combo, including the MTT temperature probe. If the wireline conditions were suitably benign, we would attempt to take a borehole water sample from near the bottom of the hole using the WSTP.

\section{Operations}

Expedition 335 operations are described in "Operations" and summarized in Table T7. The complete record of drilling in Hole 1256D and other deep basement drill holes is documented in the "Deep drilling of intact ocean crust: harnessing past lessons to inform future endeavors" chapter.

Four key issues with operations in Hole 1256D have been identified:

1. The bridge at $\sim 922$ mbsf,

2. Clearing cuttings from a deep uncased hole into oceanic basement,

3. Drilling and coring very hard formations, and

4. Logging.

\section{The bridge at 922 mbsf}

On the first reentry, a bridge was encountered at 922 mbsf that required 16 days of operations and nine reentries, including three cementing runs. Details of our best impression of the blockage are in "Operations" (Fig. F24): an inclined massive formation (e.g., base of massive flow) that squeezed the drilling bits against the borehole wall, stopping effective cutting and clearing of the blockage. Cementing and redrilling the cement above the bridge brought the hole back into gauge, restricted the lateral movement of the bit and BHA, and improved the cutting effectiveness of the tricone bit, eventually clearing the bridge and rapidly displacing lose debris in the underlying 10 to $20 \mathrm{~m}$.

Once opened and cemented, this interval did not present a problem for operations. It was stabilized with $65 \mathrm{bbl}$ of $14.5 \mathrm{ppg}$ cement at the end of Expedition 335 operations in Hole 1256D to stop further material falling into the hole or borehole wall inflow closing this interval. In hindsight, a similar operation should have been undertaken during Expedition 312, although this may have precluded reaching the benchmark achievement of coring gabbros in intact ocean crust.

\section{Clearing cuttings from a deep uncased hole into oceanic basement}

Hole $1256 \mathrm{D}$ is a $>1520 \mathrm{~m}$ deep borehole with $>1250$ $\mathrm{m}$ in uncased basement strata. Approximately $800 \mathrm{~m}$ of the hole penetrates through fragile and unstable volcanic formations of mixed competencies. This has led to large intervals being strongly out of gauge, a situation exacerbated by a total number of 62 reentries and pipe trips up and down the hole. The 16 inch casing string only extends $\sim 17 \mathrm{~m}$ into basement, below which is a $\sim 7 \mathrm{~m}$ rathole $\sim 23$ inches in diameter. The long intervals of uncased hole and the wide rathole topped by a $\sim 280 \mathrm{~m}$ section of 16 inch casing greatly reduces pumping efficiencies even when using high-viscosity muds. Expedition 335 operations cleared Hole 1256D of a large amount cuttings, some of which had probably been resident in the hole since drilling during Leg 206. At the end of Expedition 335, the hole was completely clear of cuttings, as evidenced by the near complete absence of soft fill ( $<1 \mathrm{~m}$; compare with Expedition 312, with $>50 \mathrm{~m}$ of soft fill) and a lack of mud and suspended cuttings in the reentry cone, indicating that cuttings were being successfully swept from the hole and out onto the surrounding sedimentary blanket. Improving the hydrodynamics of Hole $1256 \mathrm{D}$ to enable more efficient hole clearing would greatly improve the quality of coring activities. 


\section{Drilling and coring very hard formations}

Contact metamorphosed granoblastic basalts were encountered during Expedition 312 and destroyed a C7 RCB coring bit after only $21 \mathrm{~h}$ of rotation. Similar rocks, although with more completely developed granoblastic textures, were encountered and resulted in the absolute destruction and grinding to a smooth featureless stump of a C9 hard formation RCB coring bit after a maximum of $29 \mathrm{~h}$ (coring evidence suggests the bit failed after only $15 \mathrm{~h}$ of rotation). This was the first failure of a $\mathrm{C} 9 \mathrm{RCB}$ bit in ocean drilling. The fine-grained, annealed texture of the granoblastic basalts makes them extremely hard with few fractures. It appears that if the hole is not absolutely clear, the stresses on coring bits are such that even the smallest defect will rapidly result in equipment loss. The Expedition 309/312 Co-Chief Scientists recommended the investigation of finding ultra-hard formation drilling and coring bits. Although this recommendation was discussed by the IODP-MI Review Task Force, no progress has been made in this area. Scientific ocean drilling needs a suite of highly armored (gauge-cutters, backreamers, hard surfacing, and thick armored shirttails) drilling and coring bits for opening holes and coring in these ultra-hard intervals that can be at least $100 \mathrm{~m}$ thick.

\section{Logging}

A complete suite of wireline logs of Hole 1256D would have yielded important scientific and operational results. Only the triple combo logging tool was run, and it managed to get to full depth. Geophysical logs would have possibly provided caliper data to the bottom of the hole (FMS and UBI devices are at the bottom of the wireline tool string), as well as imaging of the distribution, size, and orientation of plutonic intrusions into the granoblastic dikes. Unfortunately, the FMS-sonic was not successfully deployed. It would not exit the logging bit, despite two attempts, because the fitting of new centralizer bowsprings significantly increased the external diameter of the logging tool beyond that of the logging bit sub. This necessitated the severance of the logging wireline using the Kinley crimping and cutting tool and the recovery of the logging tool lodged in the logging bit sub by tripping the pipe back to the rig floor. This precluded further logging operations.

\section{Going forward in Hole 1256D}

During the expedition, the Co-Chief Scientists built an effective relationship with the Transocean/Overseas Drilling Limited (ODL) drilling crews, and there was open and informative bilateral exchange of information. Communications with the TAMU Opera- tions Superintendent were excellent throughout. Following the completion of site operations, the CoChief Scientists organized a formal meeting for an effective debrief and discussion of issues encountered during Expedition 335 while these were still fresh in everyone's mind. This meeting was attended by the Co-Chief Scientists (Teagle and Ildefonse), past CoChief Scientists and leading proponents (Wilson and Alt), the Expedition Project Manager/Staff Scientist (Peter Blum), the Operations Superintendent (Ron Grout), the offshore installation manager (Sam MacLelland), the Core Technicians/Tool Pushers (Wayne Malone/Mark Robinson), and a Driller (Craig Prosser). The meeting discussed a wide range of future options (casing, cementing, tools, coring, drilling bits, and time on site) and came up with the following comments and recommendations:

- Hole 1256D is now in good condition, clear of cuttings to its total depth. Many of the cuttings removed have probably been resident in the hole since Leg 206 (from basalt textures and alteration minerals). Hole $1256 \mathrm{D}$ can be deepened toward its objectives if the recommended steps below are followed.

- Cementing has proved effective at stabilizing unstable formation, but more technical advice is required on cementing options (accelerants, etc.) and operations (e.g., packers to more effectively force cement into voids).

- Casing the complete out-of-gauge section (e.g., to 1000 mbsf in Hole 1256D) of an existing open borehole is not technically feasible in oceanic basement.

- Casing through the 16 inch casing to the bottom of the rathole with $10^{3 / 4}$ inch casing would greatly improve the hydrodynamics of the hole and enhance hole-clearing efficiencies. This operation would be reasonably straightforward and not require underreaming or other technically challenging and untested operations in hard volcanic formations.

- Return visits to Hole 1256D must be fully armed with hard/ultra-hard formation, highly armored tricone bits for hole opening and cleaning/reaming and hard/ultra-hard formation coring bits, as well as an armored suite of mills and junk baskets. The first operation upon return to Hole 1256D, before installing a $103 / 4$ inch casing string to the bottom of the rathole, will be to reenter with an armored tricone bit, drill the cement plugs and displace the cuttings, and ream and clean the bottom of the hole before coring can resume.

- The Program should investigate the feasibility of using synthetic polymer viscosifiers ("elephant 
snot") for binding and lifting cuttings from the borehole open/riserless holes (as recommended at the 309/312 ORTF meeting). (Note: There may be environmental concerns about the use of synthetic compounds in open/riserless holes.)

- The Program should consult with an experienced/ recommended drilling engineer to evaluate the best future coring plan, including the procurement (or even design and manufacture) of ultrahard formation drill/coring bits; fishing tools; and operations, cementing, and casing strategies.

- Transocean/ODL, with their rig floor expertise, should be directly involved in the planning of future deep drilling efforts at Hole 1256D and other deep targets drilled by the JOIDES Resolution.

- The Program should recognize that deep boreholes such as Holes 1256D and 504B drilled over many expeditions are as challenging endeavors as the experiments undertaken with the D/V Chikyu to date. Deep riserless boreholes require similar continuity of planning, management, and leadership. The Co-Chief Scientists from Expedition 335 and previous cruises to Hole 1256D have built up considerable expertise and experience relevant to the achievement of deep drilling targets, and they should be kept engaged in the planning and implementation of future operations. This, together with engaging the Transocean/ODL rig floor teams in the planning stage, will ensure the maximum use of a unique suite of experiences from previous operations in Hole 1256D.

- The Program should follow the recommendations of the IODP-MI Operations Review Task Force for Expedition 309/312 to investigate innovative cruise scheduling mechanisms to maximize time on site for the achievement of high-priority objectives that require deep drilling (e.g., back-to-back cruises and at-sea crew transfers).

\section{Program considerations for the attainment of deep targets by scientific ocean drilling}

Establishing the ideal location for drilling is only part of the challenge of successfully drilling moderately deep holes $(2-3 \mathrm{~km})$ to recover samples and data necessary to address long-standing primary goals of scientific ocean drilling. Experience from Holes 504B and $1256 \mathrm{D}$ indicates that such experiments require multiple cruises to achieve their target depths. Five hundred meters penetration per expedition is an upper limit for coring in the upper crust, with lesser advances and more frequent drilling challenges as these holes get deeper and are drilled into rocks metamorphosed at higher pressures and temperatures. Penetration and core recovery rates have been low to very low in the two sheeted dike complex sections drilled to date (Holes 504B and 1256D). However, experience to date suggests that gabbroic rocks can be cored relatively rapidly at high rates of recovery (e.g., Hole $\mathrm{U} 1309 \mathrm{D}=$ penetration rate $2 \mathrm{~m} / \mathrm{h}$ and $>75 \%$ recovery), so when the dike-gabbro transition zone is breached, solid progress through the plutonic section can be anticipated.

It is very unlikely that without significant good fortune deep targets in intact ocean crust can be achieved in the current science advisory configuration. The peer-review system that has overseen the progress of both Holes 504B and 1256D has required the reevaluation of new proposals following the successful completion of each drilling increment. A system similar to the complex drilling proposals (CDPs) used for riser experiments should be extended to riserless targets that require multiple expeditions to achieve important scientific goals.

Such is the capriciousness of hard rock coring that scientific ocean drilling may have to consider new approaches if it is to ever successfully address some of the major science questions that remain unanswered after more than 50 years. There are unlikely to ever be "quick wins" with targets that require multiexpedition deep boreholes. Expedition 335 was initially scheduled by the IODP-MI-OTF as a short cruise $(\sim 4$ weeks), despite the explicit recommendations of the postexpedition 309/312 ORTF report "to maximize on-site time for deep drilling expeditions" (Recommendation 309/312-03, see 309_312_ORTF.PDF in REPORTS in "Supplementary material"). Flexibility in expedition scheduling may be a low-impact means to achieve deep objectives. Back-to-back cruises to a single target could be scheduled. This approach was successful at drilling Hole U1309D >1400 mbsf during IODP Expeditions 304 and 305. Commonly, the ship has been moved off a deep hole after the significant investment in engineering and cleaning operations that have succeeded in preparing the hole for deep drilling. For example, Expedition 312 drilled $>100 \mathrm{~m}$ of the dike-plutonic transition zone in Hole 1256D following significant hole remediation operations but left an open clean deep hole. Five years later, most of the scheduled time during Expedition 335 was spent on hole remediation, and the hole is now cleaner than ever. There is a need for mechanisms for revising expedition schedules so that drilling can continue in deep boreholes when progress is actually being made. This would require the movement of crew, scientists, and supplies to and from the rig so that drilling and hole cleaning can continue, along with the temporary postponement of the immediately following expeditions. Clearly, this would be a major departure from the standard operating style of the JOIDES Resolution 
within ODP and IODP and a challenge to the science advisory and scheduling structure. It would require community acceptance that could be difficult to achieve. However, the present standard " 1 proposal = 1 expedition" approach is not an effective process to reach targets that require multiple-expedition deep drilling. Unless the community and the drilling program are able to develop new approaches to achieving deep targets, the lack of closure on science questions that can only be addressed by deep drilling will continue to stain future renewal documents with a perceived lingering staleness due to a continued recycling of unaccomplished goals.

\section{References}

Abelson, M., Baer, G., and Agnon, A., 2001. Evidence from gabbro of the Troodos ophiolite for lateral magma transport along a slow-spreading mid-ocean ridge. Nature (London, U. K.), 409(6816):72-75. doi:10.1038/ 35051058

Allerton, S., Pariso, J.E., Stokking, L.B., and McClelland, E., 1995. Origin of the natural remanent magnetism of sheeted dikes in Hole 504B cored during Legs 137 and 140. In Erzinger, J., Becker, K., Dick, H.J.B., and Stokking, L.B. (Eds.), Proc. ODP, Sci. Results, 137/140: College Station, TX (Ocean Drilling Program), 263-270. doi:10.2973/odp.proc.sr.137140.030.1995

Alt, J.C., 2004. Alteration of the upper oceanic crust: mineralogy, chemistry, and processes. In Elderfield, H., and Davis, E. (Eds.), Hydrogeology of the Oceanic Lithosphere: New York (Cambridge Univ. Press), 456-488.

Alt, J.C., Kinoshita, H., Stokking, L.B., et al., 1993. Proc. ODP, Init. Repts., 148: College Station, TX (Ocean Drilling Program). doi:10.2973/odp.proc.ir.148.1993

Alt, J.C., Laverne, C., Coggon, R.M., Teagle, D.A.H., Banerjee, N.R., Morgan, S., Smith-Duque, C.E., Harris, M., and Galli, L., 2010. Subsurface structure of a submarine hydrothermal system in ocean crust formed at the East Pacific Rise, ODP/IODP Site 1256. Geochem., Geophys., Geosyst., 11(10):Q10010. doi:10.1029/2010GC003144

Alt, J.C., Laverne, C., Vanko, D.A., Tartarotti, P., Teagle, D.A.H., Bach, W., Zuleger, E., Erzinger, J., Honnorez, J., Pezard, P.A., Becker, K., Salisbury, M.H., and Wilkens, R.H., 1996. Hydrothermal alteration of a section of upper oceanic crust in the eastern equatorial Pacific: a synthesis of results from Site 504 (DSDP Legs 69, 70, and 83, and ODP Legs 111, 137, 140, and 148.) In Alt, J.C., Kinoshita, H., Stokking, L.B., and Michael, P.J. (Eds.), Proc. ODP, Sci. Results, 148: College Station, TX (Ocean Drilling Program), 417-434. doi:10.2973/ odp.proc.sr.148.159.1996

Alt, J.C., and Teagle, D.A.H., 1999. The uptake of carbon during alteration of ocean crust. Geochim. Cosmochim. Acta, 63(10):1527-1535. doi:10.1016/S00167037(99)00123-4

Alt, J.C., and Teagle, D.A.H., 2003. Hydrothermal alteration of upper oceanic crust formed at a fast-spreading ridge: mineral, chemical, and isotopic evidence from ODP Site 801. Chem. Geol., 201(3-4):191-211. doi:10.1016/S0009-2541(03)00201-8

Bach, W., Garrido, C.J., Paulick, H., Harvey, J., and Rosner, M., 2004. Seawater-peridotite interactions: first insights from ODP Leg 209, MAR $15^{\circ}$ N. Geochem., Geophys., Geosyst., 5(9):Q09F26. doi:10.1029/2004GC000744

Bédard, J.H., Sparks, R.S.J., Renner, R., Cheadle, M.J., and Hallworth, M.A., 1988. Peridotite sills and metasomatic gabbros in the eastern layered series of the Rhum complex. J. Geol. Soc. (London, U. K.), 145(2):207-224. doi:10.1144/gsjgs.145.2.0207

Bickle, M.J., 1992. Transport mechanisms by fluid-flow in metamorphic rocks: oxygen and strontium decoupling in the Trois Seigneurs Massif: a consequence of kinetic dispersion? Am. J. Sci., 292(5): 289-316. doi:10.2475/ ajs.292.5.289

Bickle, M.J., and Teagle, D.A.H., 1992. Strontium alteration in the Troodos ophiolite: implications for fluid fluxes and geochemical transport in mid-ocean ridge hydrothermal systems. Earth Planet. Sci. Lett., 113(1-2):219237. doi:10.1016/0012-821X(92)90221-G

Boudier, F., Nicolas, A., and Ildefonse, B., 1996. Magma chambers in the Oman ophiolite: fed from the top and the bottom. Earth Planet. Sci. Lett., 144(1-2):239-250. doi:10.1016/0012-821X(96)00167-7

Browning, P., 1984. Cryptic variation within the cumulate sequence of the Oman ophiolite: magma chamber depth and petrological implications. In Gass, I.G., Lippard, S.J., and Shelton, A.W. (Eds.), Ophiolites and Oceanic Lithosphere. Geol. Soc. Spec. Publ., 13(1):71-82. doi:10.1144/GSL.SP.1984.013.01.07

Canales, J.P., Nedimovic, M.R., Kent, G.M., Carbotte, S.M., and Detrick, R.S., 2009. Seismic reflection images of a near-axis melt sill within the lower crust at the Juan de Fuca Ridge. Nature (London, U. K.), 460(7251):89-93. doi:10.1038/nature08095

Cande, S.C., and Kent, D.V., 1995. Revised calibration of the geomagnetic polarity timescale for the Late Cretaceous and Cenozoic. J. Geophys. Res., [Solid Earth], 100(B4):6093-6095. doi:10.1029/94JB03098

Carbotte, S., Mutter, C., Mutter, J., and Ponce-Correa, G., 1997. Influence of magma supply and spreading rate on crustal magma bodies and emplacement of the extrusive layer: insights from the East Pacific Rise at lat $16^{\circ} \mathrm{N}$. Geology, 26(5):455-458. doi:10.1130/0091-

7613(1998)026<0455:IOMSAS >2.3.CO;2

Carlson, R.L., 2010. How crack porosity and shape control seismic velocities in the upper oceanic crust: modeling downhole logs from Holes 504B and 1256D. Geochem., Geophys., Geosyst., 11(4):Q04007. doi:10.1029/ 2009GC002955

Chen, Y.J., 2001. Thermal effects of gabbro accretion from a deeper second melt lens at the fast spreading East Pacific Rise. J. Geophys. Res., [Solid Earth], 106(B5):85818588. doi:10.1029/2000JB900420

Coggon, R.M., Alt, J.C., and Teagle, D.A., 2008. Thermal history of ODP Hole 1256D lower sheeted dikes: petrology, chemistry and geothermometry of the granoblastic dikes. Eos, Trans. Am. Geophys. Union, 
89(53)(Suppl.):V44B-08. (Abstract) http:// www.agu.org/meetings/fm08/waisfm08.html

Coggon, R.M., Teagle, D.A.H., Cooper, M.J., and Vanko, D.A., 2004. Linking basement carbonate vein compositions to porewater geochemistry across the eastern flank of the Juan de Fuca Ridge, ODP Leg 168. Earth Planet. Sci. Lett., 219(1-2):111-128. doi:10.1016/S0012821X(03)00697-6

Coggon, R.M., Teagle, D.A.H., Smith-Duque, C.E., Alt, J.C., and Cooper, M.J., 2010. Reconstructing past seawater $\mathrm{Mg} / \mathrm{Ca}$ and $\mathrm{Sr} / \mathrm{Ca}$ from mid-ocean ridge flank calcium carbonate veins. Science, 327(5969):1114-1117. doi:10.1126/science.1182252

Coogan, L.A., Hain, A., Stahl, S., and Chakraborty, S., 2005a. Experimental determination of the diffusion coefficient for calcium in olivine between $900^{\circ} \mathrm{C}$ and $1500^{\circ}$ C. Geochim. Cosmochim. Acta, 69(14):3683-3694. doi:10.1016/j.gca.2005.03.002

Coogan, L.A., Howard, K.A., Gillis, K.M., Bickle, M.J., Chapman, H., Boyce, A.J., Jenkin, G.R.T., and Wilson, R.N., 2006. Chemical and thermal constraints on focused fluid flow in the lower oceanic crust. Am. J. Sci., 306(6):389-427. doi:10.2475/06.2006.01

Coogan, L.A., Jenkin, G.R.T., and Wilson, R.N., 2002. Constraining the cooling rate of the lower oceanic crust: a new approach applied to the Oman ophiolite. Earth Planet. Sci. Lett., 199(1-2):127-146. doi:10.1016/S0012821X(02)00554-X

Coogan, L.A., Kasemann, S.A., and Chakraborty, S., 2005b. Rates of hydrothermal cooling of new oceanic upper crust derived from lithium geospeedometry. Earth Planet. Sci. Lett., 240(2):415-424. doi:10.1016/ j.epsl.2005.09.020

Crawford, W.C., and Webb, S.C., 2002. Variations in the distribution of magma in the lower crust and at the Moho beneath the East Pacific Rise at $9^{\circ}-10^{\circ} \mathrm{N}$. Earth Planet. Sci. Lett., 203(1):117-130. doi:10.1016/S0012821X(02)00831-2

Crawford, W.C., Webb, S.C., and Hildebrand, J.A., 1999. Constraints on melt in the lower crust and Moho at the East Pacific Rise, $9^{\circ} 48^{\prime} \mathrm{N}$, using seafloor compliance measurements. J. Geophys. Res., [Solid Earth], 104(B2):2923-2939. doi:10.1029/1998JB900087

Detrick, R., Collins, J., Stephen, R., and Swift, S., 1994. In situ evidence for the nature of the seismic Layer $2 / 3$ boundary in oceanic crust. Nature (London, U. K.), 370(6487):288-290. doi:10.1038/370288a0

Detrick, R.S., Harding, A.J., Kent, G.M., Orcutt, J.A., Mutter, J.C., and Buhl, P., 1993. Seismic structure of the southern East Pacific Rise. Science, 259(5094):499-503. doi:10.1126/science.259.5094.499

Dunn, R.A., Toomey, D.R., Detrick, R.S., and Wilcock, W.S.D., 2001. Continuous mantle melt supply beneath an overlapping spreading center on the East Pacific Rise. Science, 291(5510):1955-1958. doi:10.1126/science. 1057683

Edmond, J.M., Measures, C., Magnum, B., Grant, B., Sclater, F.R., Collier, R., Hudson, A., Gordon, L.I., and Corliss, J.B., 1979. On the formation of metal-rich deposits at ridge crests. Earth. Planet. Sci. Lett., 46(1):1930. doi:10.1016/0012-821X(79)90062-1

Expedition 309/312 Scientists, 2006. Site 1256. In Teagle, D.A.H., Alt, J.C., Umino, S., Miyashita, S., Banerjee, N.R., Wilson, D.S., and the Expedition 309/312 Scientists. Proc. IODP, 309/312: Washington, DC (Integrated Ocean Drilling Program Management International, Inc.). doi:10.2204/iodp.proc.309312.103.2006

Expedition 335 Scientists, 2012a. Deep drilling of intact ocean crust: harnessing past lessons to inform future endeavors. In Teagle, D.A.H., Ildefonse, B., Blum, P., and the Expedition 335 Scientists, Proc. IODP, 335: Tokyo (Integrated Ocean Drilling Program Management International, Inc.). doi:10.2204/iodp.proc.335.104.2012

Expedition 335 Scientists, 2012b. Methods. In Teagle, D.A.H., Ildefonse, B., Blum, P., and the Expedition 335 Scientists, Proc. IODP, 335: Tokyo (Integrated Ocean Drilling Program Management International, Inc.). doi:10.2204/iodp.proc.335.102.2012

Expedition 335 Scientists, 2012c. Site 1256. In Teagle, D.A.H., Ildefonse, B., Blum, P., and the Expedition 335 Scientists, Proc. IODP, 335: Tokyo (Integrated Ocean Drilling Program Management International, Inc.). doi:10.2204/iodp.proc.335.103.2012

Farrell, J.W., Raffi, I., Janecek, T.R., Murray, D.W., Levitan, M., Dadey, K.A., Emeis, K.-C., Lyle, M., Flores, J.-A., and Hovan, S., 1995. Late Neogene sedimentation patterns in the eastern equatorial Pacific Ocean. In Pisias, N.G., Mayer, L.A., Janecek, T.R., Palmer-Julson, A., and van Andel, T.H. (Eds.), Proc. ODP, Sci. Results, 138: College Station, TX (Ocean Drilling Program), 717-756. doi:10.2973/odp.proc.sr.138.143.1995

France, L., Ildefonse, B., and Koepke, J., 2009. Interactions between magma and the hydrothermal system in the Oman ophiolite and in IODP Hole 1256D: fossilisation of dynamic melt lens at fast spreading ridges. Geochem., Geophys., Geosyst., 10(10):Q10O19. doi:10.1029/ 2009GC002652

Francheteau, J., Armijo, R., Cheminée, J.L., Hekinian, R., Lonsdale, P., and Blum, N., 1992. Dyke complex of the East Pacific Rise exposed in the walls of Hess Deep and the structure of the upper oceanic crust. Earth Planet. Sci. Lett., 111(1):109-121. doi:10.1016/ 0012-821X(92)90173-S

Garmany, J., 1989. Accumulations of melt at the base of young oceanic crust. Nature (London, U. K.), 340(6235):628-632. doi:10.1038/340628a0

Gilbert, L.A., and Salisbury, M.H., 2011. Oceanic crustal velocities from laboratory and logging measurements of Integrated Ocean Drilling Program Hole 1256D. Geochem., Geophys., Geosyst., 12:Q09001. doi:10.1029/ 2011GC003750

Gillis, K.M., 1995. Controls on hydrothermal alteration in a section of fast-spreading oceanic crust. Earth Planet. Sci. Lett., 134(3-4):473-489. doi:10.1016/ 0012-821X(95)00137-2

Gillis, K.M., 2008. The roof of an axial magma chamber: a hornfelsic heat exchanger. Geology, 36(4):299-302. doi:10.1130/G24590A.1 
Gillis, K.M., Coogan, L.A., and Pedersen, R., 2005. Strontium isotope constraints on fluid flow in the upper oceanic crust at the East Pacific Rise. Earth Planet. Sci. Lett., 232(1-2):83-94. doi:10.1016/j.epsl.2005.01.008

Gillis, K.M., and Roberts, M.D., 1999. Cracking at the magma-hydrothermal transition: evidence from the Troodos ophiolite, Cyprus. Earth Planet. Sci. Lett., 169(34):227-244. doi:10.1016/S0012-821X(99)00087-4

Gregory, R.T., and Taylor, H.P., Jr., 1981. An oxygen isotope profile in a section of Cretaceous oceanic crust, Samail ophiolite, Oman: evidence for $\delta^{18} \mathrm{O}$ buffering of the oceans by deep ( $>5 \mathrm{~km}$ ) seawater-hydrothermal circulation at mid-ocean ridges. J. Geophys. Res., [Solid Earth], 86(B4):2737-2755. doi:10.1029/JB086iB04p02737

Guérin, G., Goldberg, D.S., and Iturrino, G.J., 2008. Velocity and attenuation in young oceanic crust: new downhole log results from DSDP/ODP/IODP Holes 504B and 1256D. Geochem., Geophys., Geosyst., 9(12):Q12014. doi:10.1029/2008GC002203

Hallenborg, E., Harding, A.J., Kent, G.M., and Wilson, D.S., 2003. Seismic structure of 15 Ma oceanic crust formed at an ultrafast spreading East Pacific Rise: evidence for kilometer-scale fracturing from dipping reflectors. $J$. Geophys. Res., [Solid Earth], 108(B11):2532. doi:10.1029/ 2003JB002400

Heberling, C., Lowell, R.P., Liu, L., and Fisk, M.R., 2010. Extent of the microbial biosphere in the oceanic crust. Geochem., Geophys., Geosyst., 11(8):Q08003. doi:10.1029/2009GC002968

Henstock, T.J., Woods, A.W., and White, R.S., 1993. The accretion of oceanic crust by episodic sill intrusion. $J$. Geophys. Res., [Solid Earth], 98(B3):4143-4161. doi:10.1029/92JB02661

Hooft, E.E.E., Detrick, R.S., and Kent, G.M., 1994. Seismic structure and indicators of magma budget along the southern East Pacific Rise. J. Geophys. Res., [Solid Earth], 102(B12):27319-27340.

Hooft, E.E.E., Schouten, H., and Detrick, R.S., 1996. Constraining crustal emplacement processes from variation in seismic Layer 2A thickness at the East Pacific Rise. Earth Planet. Sci. Lett., 142(3-4):289-309. doi:10.1016/ 0012-821X(96)00101-X

Jupp, T., and Schultz, A., 2000. A thermodynamic explanation for black smoker temperatures. Nature (London, $U$. K.), 403(6772):880-883. doi:10.1038/35002552

Karson, J.A., 2002. Geologic structure of the uppermost oceanic crust created at fast- to intermediate-rate spreading centers. Annu. Rev. Earth Planet. Sci., 30:347384. doi:10.1146/annurev.earth.30.091201.141132

Karson, J.A., Hurst, S.D., and Lonsdale, P., 1992. Tectonic rotations of dikes in fast-spread oceanic crust exposed near Hess Deep. Geology, 20(8):685-688. doi:10.1130/ 0091-7613(1992)020<0685:TRODIF >2.3.CO;2

Karson, J.A., Klein, E.M., Hurst, S.D., Lee, C.E., Rivizzigno, P.A., Curewitz, D., Morris, A.R., Miller, D.J., Varga, R.G., Christeson, G.L., Cushman, B., O’Neill, J.M., Brophy, J.G., Gillis, K.M., Stewart, M.A., and Sutton, A.L., 2002. Structure of uppermost fast-spread oceanic crust exposed at the Hess Deep Rift: implications for subaxial processes at the East Pacific Rise. Geochem., Geophys., Geosyst., 3(1):1002. doi:10.1029/2001GC000155

Kelemen, P.B., and Aharonov, E., 1998. Periodic formation of magma fractures and generation of layered gabbros in the lower crust beneath oceanic spreading centers. In Buck, R., Delaney, P.T., Karson, J.A., and Lagabrielle, Y. (Eds.), Faulting and Magmatism at Mid-Ocean Ridges. Geophys. Monogr., 106:267-289.

Kelemen, P.B., Koga, K., and Shimizu, N., 1997. Geochemistry of gabbro sills in the crust-mantle transition zone of the Oman ophiolite: implications for the origin of the oceanic lower crust. Earth Planet. Sci. Lett., 146(34):475-488. doi:10.1016/S0012-821X(96)00235-X

Kent, G.M., Harding, A.J., Orcutt, J.A., Detrick, R.S., Mutter, J.C., and Buhl, P., 1994. Uniform accretion of oceanic crust south of the Garrett transform at $14^{\circ} 15^{\prime} \mathrm{S}$ on the East Pacific Rise. J. Geophys. Res., [Solid Earth], 99(B5):9097-9116. doi:10.1029/93JB02872

Koepke, J., Christie, D.M., Dziony, W., Holtz, F., Lattard, D., Maclennan, J., Park, S., Scheibner, B., Yamasaki, T., and Yamazaki, S., 2008. Petrography of the dike-gabbro transition at IODP Site 1256 (equatorial Pacific): the evolution of the granoblastic dikes. Geochem., Geophys., Geosyst., 9(7):Q07O09. doi:10.1029/2008GC001939

Koepke, J., Berndt, J., Feig, S.T., and Holtz, F., 2007. The formation of $\mathrm{SiO}_{2}$-rich melts within the deep ocean crust by hydrous partial melting of gabbros. Contrib. Mineral. Petrol., 153(1):67-84. doi:10.1007/s00410-0060135-y

Korenaga, J., and Kelemen, P.B., 1997. Origin of gabbro sills in the Moho transition zone of the Oman ophiolite: implications for magma transport in the oceanic lower crust. J. Geophys. Res., [Solid Earth], 102(B12):27729-27749. doi:10.1029/97JB02604

Korenaga, J., and Kelemen, P.B., 1998. Melt migration through the oceanic lower crust: a constraint from melt percolation modeling with finite solid diffusion. Earth Planet. Sci. Lett., 156(1-2):1-11. doi:10.1016/ S0012-821X(98)00004-1

Langmuir, C.H., Bender, J.F., and Batiza, R., 1986. Petrological and tectonic segmentation of the East Pacific Rise, $5^{\circ} 30^{\prime} \mathrm{N}-14^{\circ} 30^{\prime} \mathrm{N}$. Nature (London, U. K.), 322(6078):422429. doi:10.1038/322422a0

Macdonald, K.C., Fox, P.J., Alexander, R.T., Pockalny, R., and Gente, P., 1996. Volcanic growth faults and the origin of Pacific abyssal hills. Nature (London, U. K.), 380(6570):125-129. doi:10.1038/380125a0

Macdonald, K.C., Haymon, R., and Shor, A., 1989. A 220 $\mathrm{km}^{2}$ recently erupted lava field on the East Pacific Rise near lat $8^{\circ}$ S. Geology, 17(3):212-216. doi:10.1130/00917613(1989)017<0212:AKRELF>2.3.CO;2

Maclennan, J., Hulme, T., and Singh, S.C., 2005. Cooling of the lower oceanic crust. Geology, 33(5):357-366. doi:10.1130/G21207.1

MacLeod, C.J., and Yaouancq, G., 2000. A fossil melt lens in the Oman ophiolite: implications for magma chamber processes at fast spreading ridges. Earth Planet. Sci. Lett., 176(3-4):357-373. doi:10.1016/S0012821X(00)00020-0 
Manning, C.E., Weston, P.E., and Mahon, K.I., 1996. Rapid high-temperature metamorphism of East Pacific Rise gabbros from Hess Deep. Earth Planet. Sci. Lett., 144(12):123-132. doi:10.1016/0012-821X(96)00153-7

Meurer, W.P., and Gee, J., 2002. Evidence for the protracted construction of slow-spread oceanic crust by small magmatic injections. Earth Planet. Sci. Lett., 201(1):45-55. doi:10.1016/S0012-821X(02)00660-X

Miyashita, S., Adachi, Y., and Tanaka, S., 2007. Partial melting of oceanic crust: anatectitites in the gabbro-dike transition of Oman ophiolite. Geochim. Cosmochim. Acta, 71(15)(Suppl.):A675. (Abstract) http://goldschmidt.info/2007/abstracts/A675.pdf

Morris, A., Gee, J.S., Pressling, N., John, B.E., MacLeod, C.J., Grimes, C.B., and Searle, R.C., 2009. Footwall rotation in an oceanic core complex quantified using reoriented Integrated Ocean Drilling Program core samples. Earth Planet. Sci. Lett., 287(1-2):217-228. doi:10.1016/ j.eps1.2009.08.007

Müller, R.D., Sdrolias, M., Gaina, C., and Roest, W.R., 2008. Age, spreading rates, and spreading asymmetry of the world's ocean crust. Geochem., Geophys., Geosyst., 9(4):Q04006. doi:10.1029/2007GC001743

Natland, J.H., and Dick, H.J.B., 1996. Melt migration through high-level gabbroic cumulates of the East Pacific Rise at Hess Deep: the origin of magma lenses and the deep crustal structure of fast-spreading ridges. In Mével, C., Gillis, K.M., Allan, J.F., and Meyer, P.S. (Eds.), Proc. ODP, Sci. Results, 147: College Station, TX (Ocean Drilling Program), 21-58. doi:10.2973/ odp.proc.sr.147.002.1996

Nedimovic, M.R., Carbotte, S.M., Harding, A.J., Detrick, R.S., Canales, J.P., Diebold, J.B., Kent, G.M., Tischer, M., and Babcock, J.M., 2005. Frozen magma lenses below the oceanic crust. Nature (London, U. K.), 436(7054):1149-1152. doi:10.1038/nature03944

Nicolas, A., and Boudier, F., 1991. Rooting of the sheeted dike complex in the Oman ophiolite. In Peters, T., Nicolas, A., and Coleman, R.G. (Eds.), Ophiolite Genesis and Evolution of Oceanic Lithosphere: Boston (Kluwer Acad.), 39-54.

Nicolas, A., Boudier, F., and France, L., 2009. Subsidence in magma chamber and the development of magmatic foliation in Oman ophiolite gabbros. Earth Planet. Sci. Lett., 284(1-2):76-87. doi:10.1016/j.epsl.2009.04.012

Nicolas, A., Boudier, F., and Ildefonse, B., 1996. Variable crustal thickness in the Oman ophiolite: implication for oceanic crust. J. Geophys. Res., [Solid Earth], 101(B8):17941-17950. doi:10.1029/96JB00195

Nicolas, A., Boudier, F., Ildefonse, B., and Ball, E., 2000. Accretion of Oman and United Arab Emirates ophiolite-discussion of a new structural map. Mar. Geophys. Res., 21(3-4):147-180. doi:10.1023/A:1026769727917

Pallister, J.S., and Hopson, C.A., 1981. Samail ophiolite plutonic suite: field relations, phase variation, cryptic variation and layering, and a model of a spreading ridge magma chamber. J. Geophys. Res., [Solid Earth], 86(B4):2593-2644. doi:10.1029/JB086iB04p02593

Park, S., Maclennan, J., Teagle, D., and Hauff, F., 2008. Did the Galápagos plume influence the ancient EPR?: a geo- chemical study of basaltic rocks from Hole 1256D. Eos, Trans. Am. Geophys. Union, 89(53)(Suppl.):V51F-2097. (Abstract) http://www.agu.org/meetings/fm08/ waisfm08.html

Parsons, B., and Sclater, J.G., 1977. An analysis of the variation of ocean floor bathymetry and heat flow with age. J. Geophys. Res., [Solid Earth], 82:803-827. doi:10.1029/ JB082i005p00803

Phipps Morgan, J., and Chen, Y.J., 1993. The genesis of oceanic crust: magma injection, hydrothermal circulation, and crustal flow. J. Geophys. Res., [Solid Earth], 98(B4):6283-6297. doi:10.1029/92JB02650

Potter, D.K., 2004. A comparison of anisotropy of magnetic remanence methods-a user's guide for application to palaeomagnetism and magnetic fabric studies. In Martín-Hernández, F., Lüneburg, C.M., Aubourg, C., and Jackson, M. (Eds.), Magnetic Fabric: Methods and Applications. Geol. Soc. Spec. Publ., 238(1):21-35. doi:10.1144/ GSL.SP.2004.238.01.03

Purdy, G.M., Kong, L.S.L., Christeson, G.L., and Solomon, S.C., 1992. Relationship between spreading rate and the seismic structure of mid-ocean ridges. Nature (London, $U$. K.), 355(6363):815-817. doi:10.1038/355815a0

Quick, J.E., and Denlinger, R.P., 1993. Ductile deformation and the origin of layered gabbro in ophiolites. J. Geophys. Res., [Solid Earth], 98(B8):14015-14027. doi:10.1029/93JB00698

Schneider, D.A., 1988. An estimate of the long-term nondipole field from marine magnetic anomalies. Geophys. Res. Lett., 15(10):1105-1108. doi:10.1029/ GL015i010p01105

Singh, S.C., Kent, G.M., Collier, J.S., Harding, A.J., and Orcutt, J.A., 1998. Melt to mush variations in crustal magma properties along the ridge crest at the southern East Pacific Rise. Nature (London, U. K.), 394(6696):874878. doi:10.1038/29740

Sinton, J.M., and Detrick, R.S., 1992. Mid-ocean ridge magma chambers. J. Geophys. Res., [Solid Earth], 97(B1):197-216. doi:10.1029/91JB02508

$\mathrm{Su}$, Y., and Langmuir, C.H., 2003. Global MORB chemistry compilation at segment scale [Ph.D. dissert.]. Columbia Univ., New York.

Swift, S., Reichow, M., Tikku, A., Tominaga, M., and Gilbert, L., 2008. Velocity structure of upper ocean crust at Ocean Drilling Program Site 1256. Geochem., Geophys., Geosyst., 9(10):Q10O13. doi:10.1029/2008GC002188

Teagle, D., and Ildefonse, B., 2011. Journey to the mantle of the Earth. Nature (London, U. K.), 471(7339):437-439. doi:10.1038/471437a

Teagle, D.A.H., Alt, J.C., and Halliday, A.N., 1998a. Tracing the chemical evolution of fluids during hydrothermal recharge: constraints from anhydrite recovered in ODP Hole 504B. Earth Planet. Sci. Lett., 155(3-4):167-182. doi:10.1016/S0012-821X(97)00209-4

Teagle, D.A.H., Alt, J.C., and Halliday, A.N., 1998b. Tracing the evolution of hydrothermal fluids in the upper oceanic crust: Sr-isotopic constraints from DSDP/ODP Holes 504B and 896A. In Harrison, K., and Mills, R.A. (Eds.), Modern Ocean Floor Processes and the Geological 
Record. Geol. Soc. Spec. Publ., 148(1):81-97. doi:10.1144/GSL.SP.1998.148.01.06

Teagle, D.A.H., Alt, J.C., Umino, S., Miyashita, S., Banerjee, N.R., Wilson, D.S., and Expedition 309/312 Scientists, 2006. Proc. IODP, 309/312: Washington, DC (Integrated Ocean Drilling Program Management International, Inc.). doi:10.2204/iodp.proc.309312.2006

Teagle, D.A.H., and Bickle, M.J., 1993. The transport and exchange of geochemical tracers by fluid-rock interaction: application of theory to ancient and modern ocean crust. RIDGE Events, 4(2):5-9.

Teagle, D.A.H., Bickle, M.J., and Alt, J.C., 2003. Recharge flux to ocean-ridge black smoker systems: a geochemical estimate from ODP Hole 504B. Earth Planet. Sci. Lett., 210(1-2):81-89. doi:10.1016/S0012-821X(03)00126-2

Teagle, D.A.H, Ildefonse, B., and Blum, P., 2010. Superfast spreading rate crust 4. IODP Sci. Prosp., 335. doi:10.2204/iodp.sp.335.2010

Tominaga, M., Teagle, D.A.H., Alt, J.C., and Umino, S., 2009. Determination of volcanostratigraphy of the oceanic crust formed at superfast spreading ridge: electrofacies analyses of ODP/IOPD Hole 1256D. Geochem., Geophys., Geosyst., 10(1):Q01003. doi:10.1029/ 2008GC002143

Tominaga, M., and Umino, S., 2010. Lava deposition history in ODP Hole 1256D: insights from log-based volcanostratigraphy. Geochem., Geophys., Geosyst., 11(5):Q05003. doi:10.1029/2009GC002933

Umino, S., Lipman, P.W., and Obata, S., 2000. Subaqueous lava flow lobes, observed on ROV Kaiko dives off Hawaii. Geology, 28(6):503-506. doi:10.1130/00917613(2000)28<503:SLFLOO>2.0.CO;2

Van Tongeren, J.A., Kelemen, P.B., and Hanghøj, K., 2008. Cooling rates in the lower crust of the Oman ophiolite: Ca in olivine, revisited. Earth Planet. Sci. Lett., 267(12):69-82. doi:10.1016/j.epsl.2007.11.034

Violay, M., Pezard, P.A., Ildefonse, B., Belghoul, A., and Laverne, C., 2010. Petrophysical properties of the root zone of sheeted dikes in the ocean crust: a case study from Hole ODP/IODP 1256D, eastern equatorial Pacific. Tectonophysics, 493(1-2):139-152. doi:10.1016/ j.tecto.2010.07.013

White, S.M., Hayman, R.M., Fornari, D.J., Perfit, M.R., and Macdonald, K.C., 2002. Correlation between volcanic and tectonic segmentation of fast-spreading ridges: evidence from volcanic structures and lava flow morphol- ogy on the East Pacific Rise at $9^{\circ}-10^{\circ}$ N. J. Geophys. Res., [Solid Earth], 107(B8):2173. doi:10.1029/2001JB000571

White, S.M., Macdonald, K.C., and Haymon, R.M., 2000.

Basaltic lava domes, lava lakes, and volcanic segmentation on the southern East Pacific Rise. J. Geophys. Res., [Solid Earth], 105(B10):23519-23536. doi:10.1029/ 2000JB900248

Wilson, D.S., 1996. Fastest known spreading on the Miocene Cocos-Pacific plate boundary. Geophys. Res. Lett., 23(21):3003-3006. doi:10.1029/96GL02893

Wilson, D.S., Hallenborg, E., Harding, A.J., and Kent, G.M., 2003. Data report: site survey results from Cruise EW9903. In Wilson, D.S., Teagle, D.A.H., Acton, G.D., Proc. ODP, Init. Repts., 206: College Station, TX (Ocean Drilling Program), 1-49. doi:10.2973/ odp.proc.ir.206.104.2003

Wilson, D.S., Teagle, D.A.H., Acton, G.D., et al., 2003. Proc. ODP, Init. Repts., 206: College Station, TX (Ocean Drilling Program). doi:10.2973/odp.proc.ir.206.2003

Wilson, D.S., Teagle, D.A.H., Alt, J.C., Banerjee, N.R., Umino, S., Miyashita, S., Acton, G.D., Anma, R., Barr, S.R., Belghoul, A., Carlut, J., Christie, D.M., Coggon, R.M., Cooper, K.M., Cordier, C., Crispini, L., Durand, S.R., Einaudi, F., Galli, L., Gao, Y., Geldmacher, J., Gilbert, L.A., Hayman, N.W., Herrero-Bervera, E., Hirano, N., Holter, S., Ingle, S., Jiang, S., Kalberkamp, U., Kerneklian, M., Koepke, J., Laverne, C., Vasquez, H.L.L., Maclennan, J., Morgan, S., Neo, N., Nichols, H.J., Park, S.-H., Reichow, M.K., Sakuyama, T., Sano, T., Sandwell, R., Scheibner, B., Smith-Duque, C.E., Swift, S.A., Tartarotti, P., Tikku, A.A., Tominaga, M., Veloso, E.A., Yamasaki, T., Yamazaki, S., and Ziegler, C., 2006. Drilling to gabbro in intact ocean crust. Science, 312(5776):1016-1020. doi:10.1126/science.1126090

Yamazaki, S., Neo, N., and Miyashita, S., 2009. Data report: whole-rock major and trace elements and mineral compositions of the sheeted dike-gabbro transition in ODP Hole 1256D. In Teagle, D.A.H., Alt, J.C., Umino, S., Miyashita, S., Banerjee, N.R., Wilson, D.S., and the Expedition 309/312 Scientists, Proc. IODP, 309/312: Washington, DC (Integrated Ocean Drilling Program Management International, Inc.). doi:10.2204/ iodp.proc.309312.203.2009

Publication: 3 June 2012 MS 335-101 
Figure F1. Age map of the Cocos plate and corresponding regions of the Pacific and Nazca plates. Isochrons at 5 m.y. intervals have been converted from magnetic anomaly identifications according to the timescale of Cande and Kent (1995). Selected DSDP and ODP sites that reached basement are indicated by circles. The wide spacing of the 10 to $20 \mathrm{Ma}$ isochrons to the south reflects the extremely fast (200-220 mm/y) full spreading rate. Dashed box shows location of Figure F7A, which shows details of magnetic anomalies near Site 1256. FZ $=$ fracture zone.

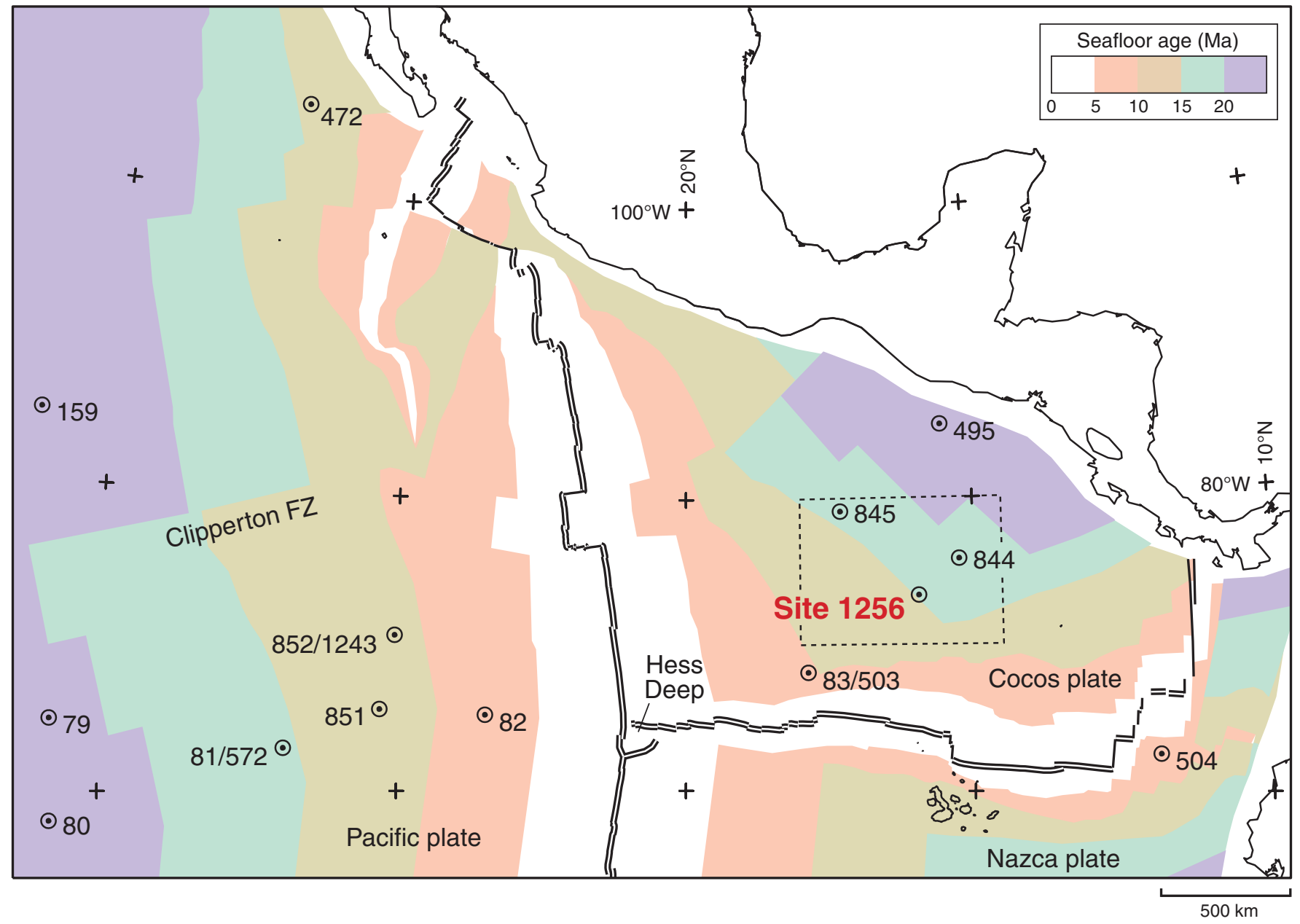


Figure F2. Simplified stratigraphy column of Hole 1256D at the end of Expedition 312, showing the major lithologic divisions of the upper oceanic crust at this site, the progress made during previous drilling cruises (Leg 206 and Expedition 309/312), and the highly variable core recovery.

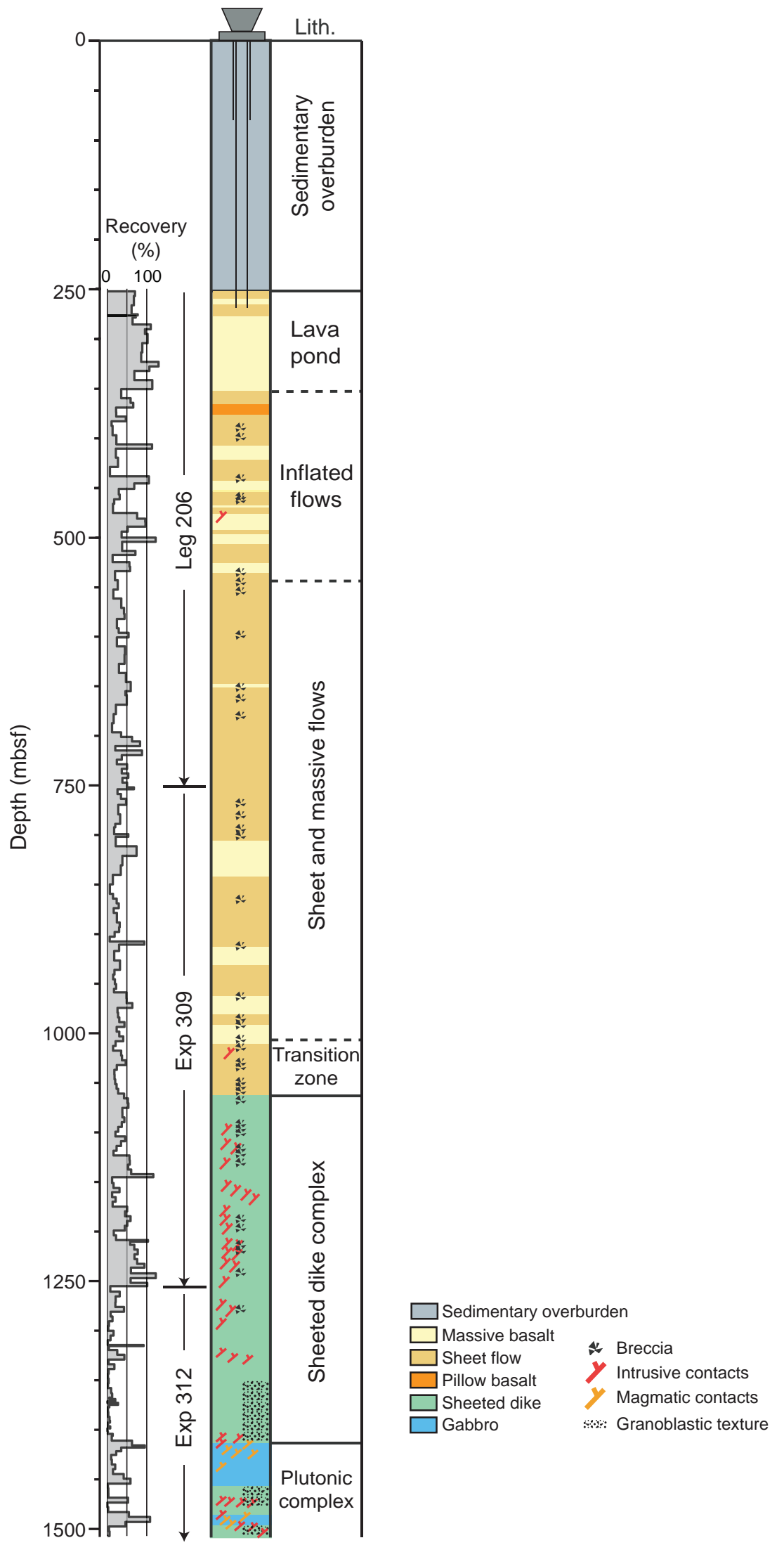


Figure F3. Map of ocean floor age, based on age grid by Müller et al. (2008, revised version 3; www.earthbyte.org/). Symbols represent DSDP, ODP, and IODP holes drilled in ocean crust $>100$ mbsf from 1974 to 2011 . Holes deeper than $500 \mathrm{~m}$ in intact and rifted oceanic crust are labeled. This map does not include "hard rock" drill holes in oceanic plateaus, arc basement, hydrothermal mounds, or passive margins.

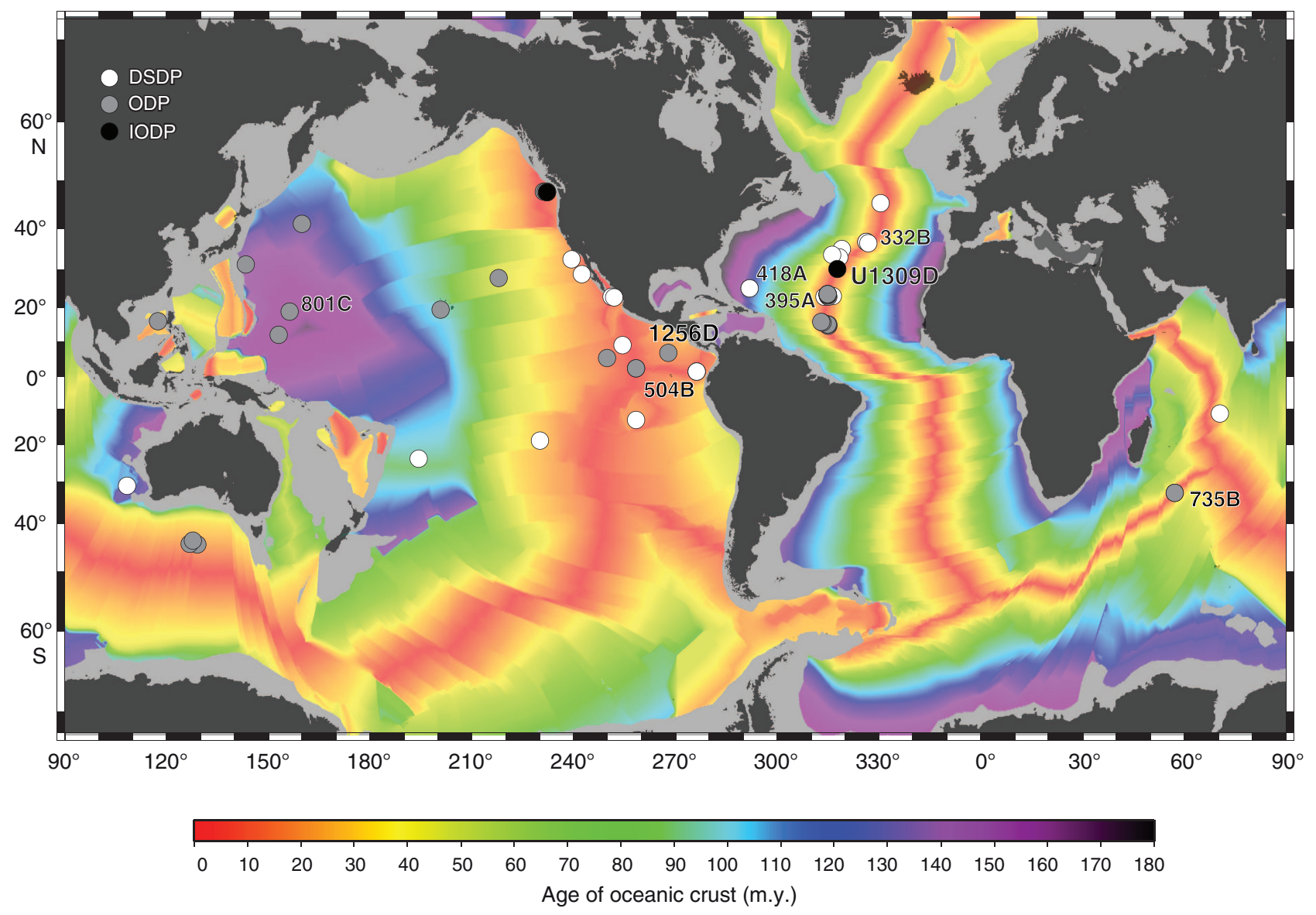


Figure F4. Compilation chart showing holes drilled $>100 \mathrm{~m}$ in intact crust and tectonically exposed lower crust and upper mantle from 1974 to 2010 (drill hole locations in Fig. F3). For each hole are indicated the hole number and the recovery (in percent) for each lithology. This compilation does not include "hard rock" drill holes in oceanic plateaus, arc basement, hydrothermal mounds, or passive margins.

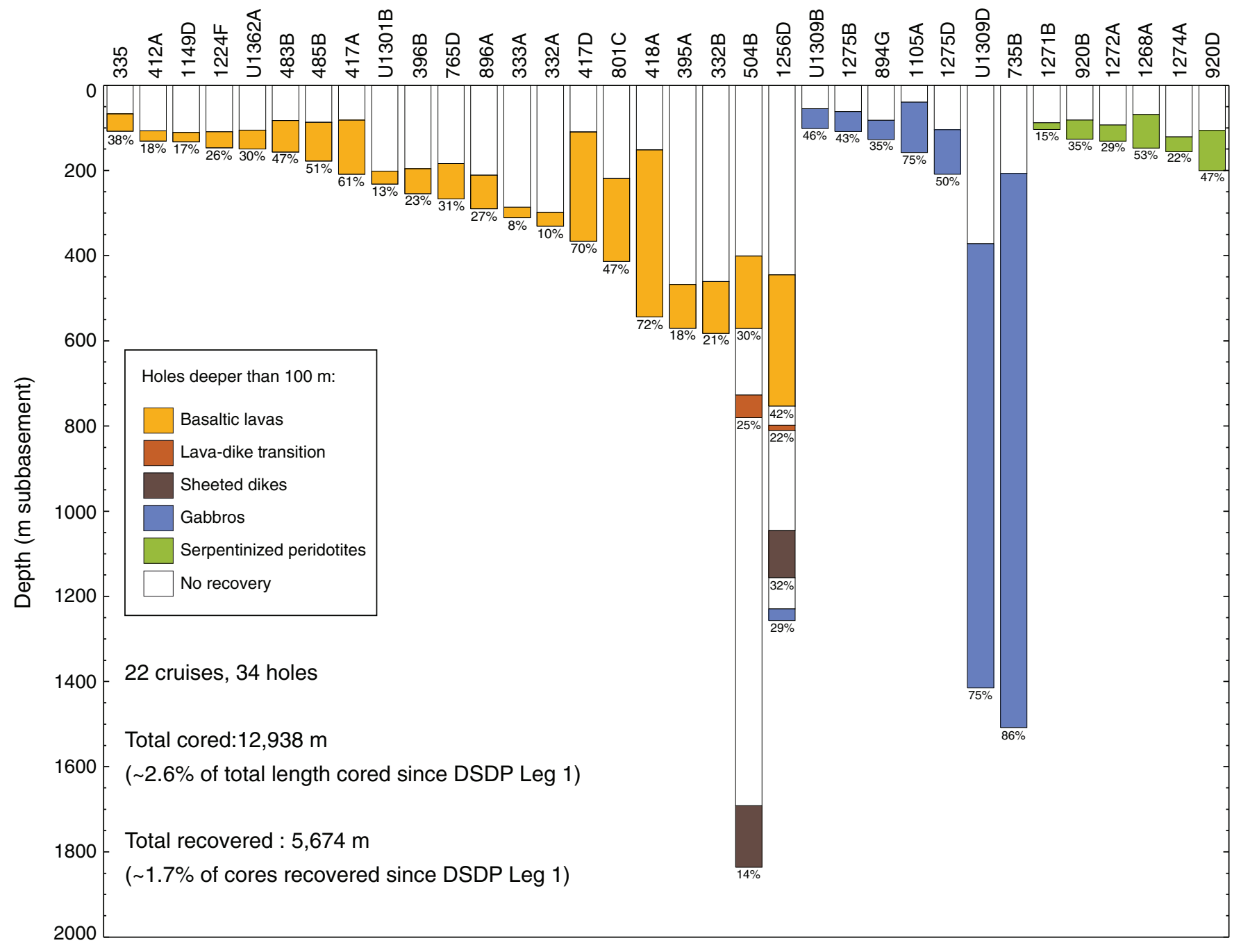


Figure F5. Depth to axial low-velocity zone plotted against spreading rate (Purdy et al., 1992; Carbotte et al., 1997). Depth versus spreading rate predictions from two models of Phipps Morgan and Chen (1993) are shown, extrapolated subjectively to $200 \mathrm{~mm} / \mathrm{y}$. Penetration to date in Holes 504B and 1256D is shown, with the depth at which gabbros were intersected indicated by the red box. Following core descriptions, a thickness of $\sim 300 \mathrm{~m}$ of off-axis lava is shown for Hole 1256D and assumed for Hole 504B. EPR = East Pacific Rise, JdF = Juan de Fuca Ridge, Lau = Valu Fa Ridge in Lau Basin, CRR = Costa Rica Rift, MAR = Mid-Atlantic Ridge.

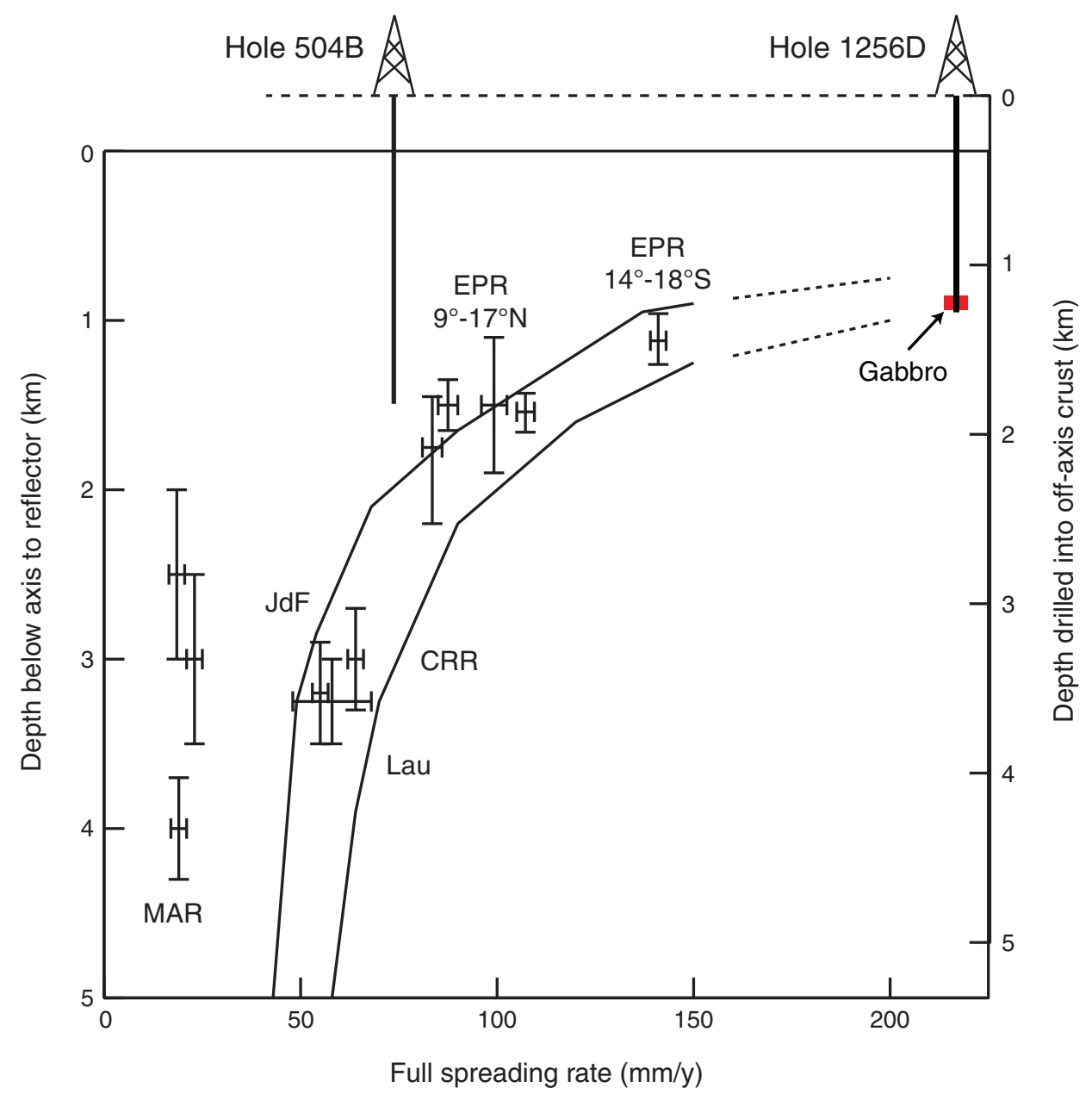


Figure F6. Reconstruction of Site 1256 and vicinity at 14 Ma, $~ 1$ m.y. after formation of the site at the East Pacific Rise. Positions and plate velocities (arrows labeled in millimeters per year) are relative to the Antarctic plate, which is reasonably fixed relative to the spin axis and hotspots. Reconstructed positions of mapped magnetic Anomalies 5B, 5C, and 6 (ages 15-20 Ma) and other existing DSDP/ODP drill sites are shown by colored bars and circles, respectively.

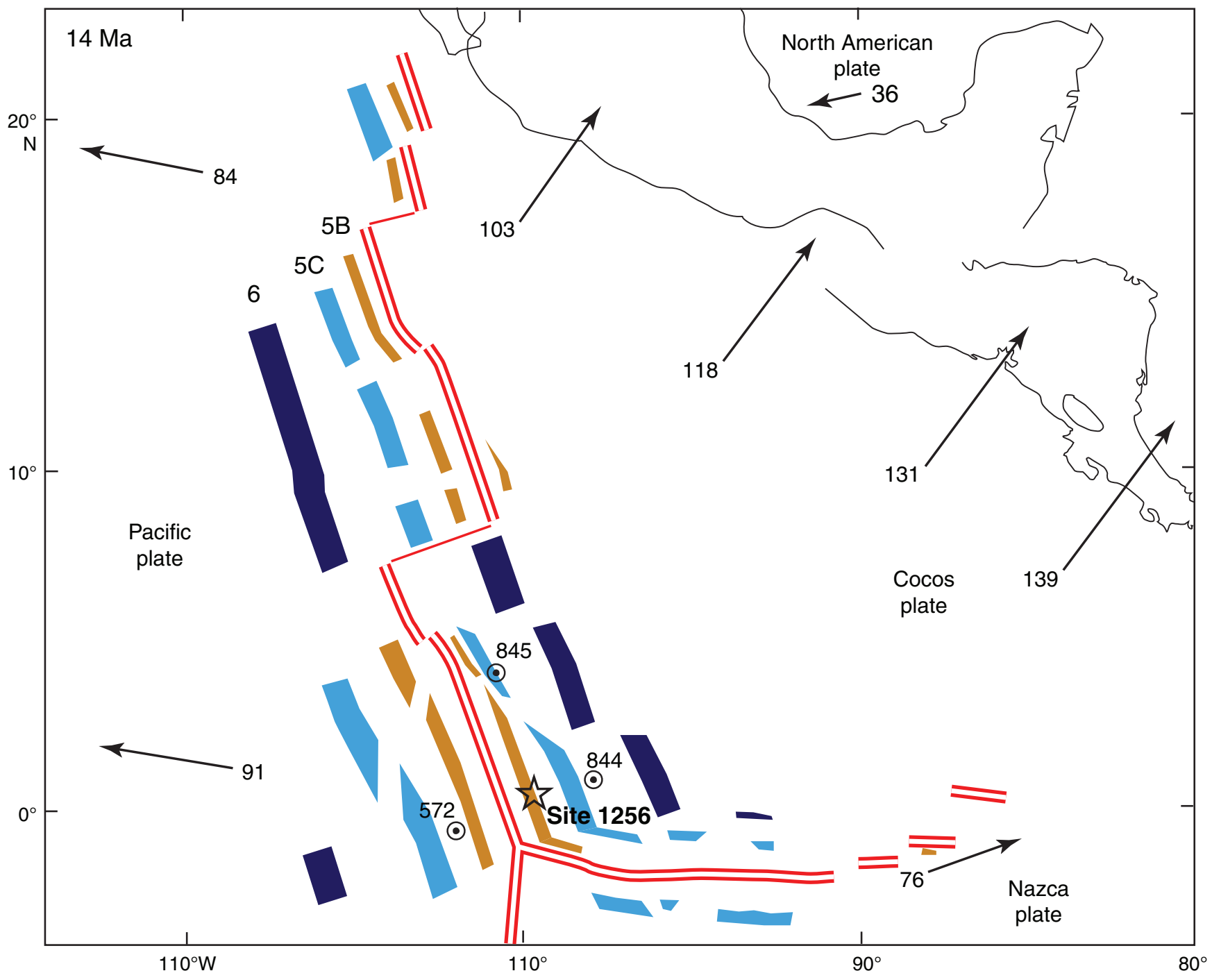


Figure F7. A. Details of isochrons inferred from magnetic anomalies near Site 1256. Shading shows normal magnetic polarity, based on digitized reversal boundaries (small circles, after Wilson, 1996). Bold line shows location of Guatemala Basin multichannel seismic (MCS) tracklines from the site survey Cruise EW9903 conducted in March-April 1999 (Wilson et al., 2003). Anomaly ages: 5A = 12 Ma, 5B =15 Ma, and 5D = 17 Ma. B. Bathymetry and site survey track map for Site 1256 (proposed Site GUATB-03C). Abyssal hill relief of as much as $100 \mathrm{~m}$ is apparent in the southwest part of the area; relief to the northeast is lower and less organized. Line numbers 21-28 identify MCS lines from the site survey. $\mathrm{OBH}=$ ocean bottom hydrophone.
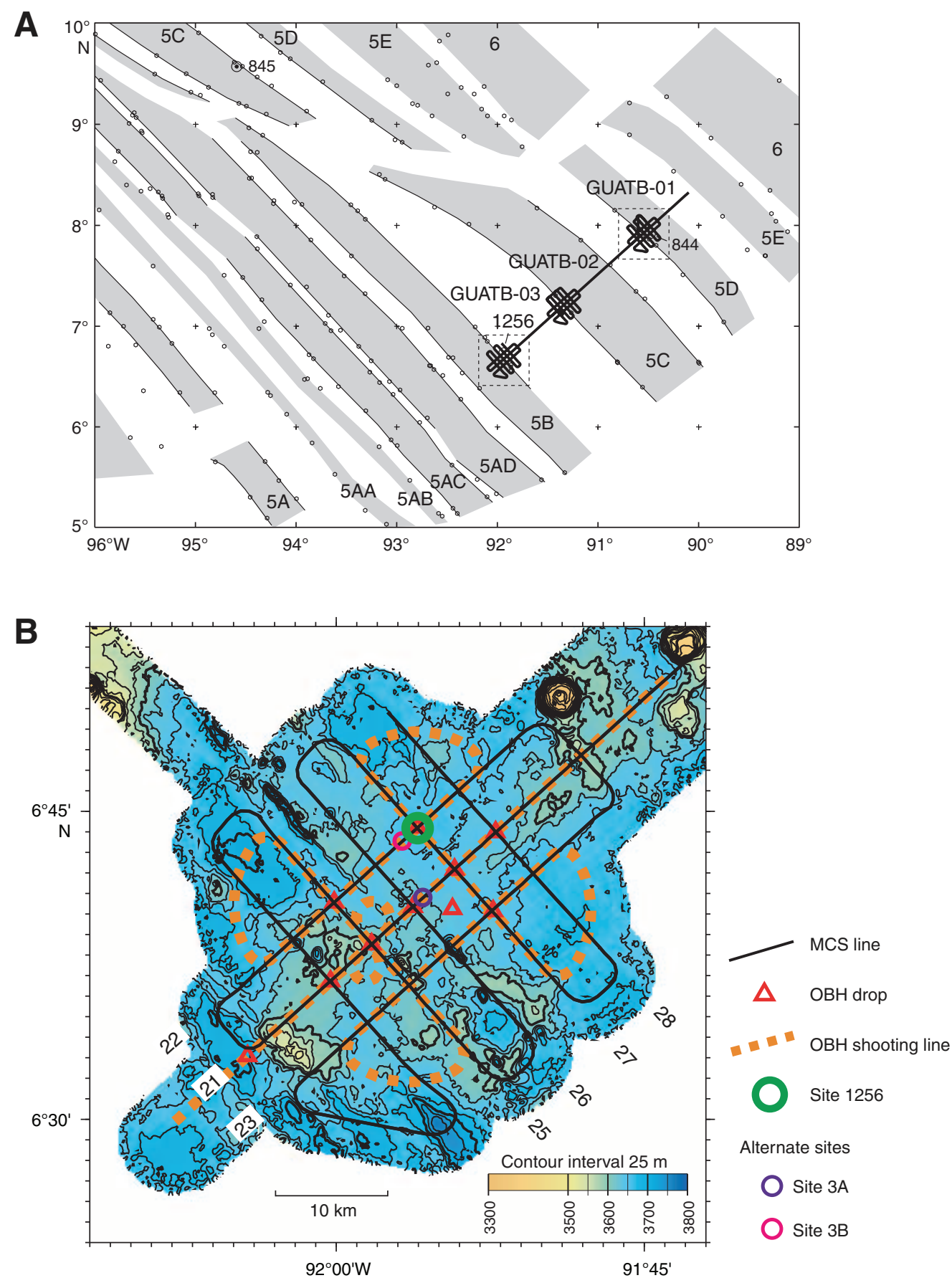
Figure F8. Site survey MCS data (Hallenborg et al., 2003) from the lines that cross at Site 1256, with penetration as of the end of Expedition 335 scaled approximately to traveltime. Horizontal reflectors in the upper basement to traveltimes of $5.5 \mathrm{~s}$ appear to result from contrasts between lava flow sequences, corresponding to depths of at least $800 \mathrm{msb}$.
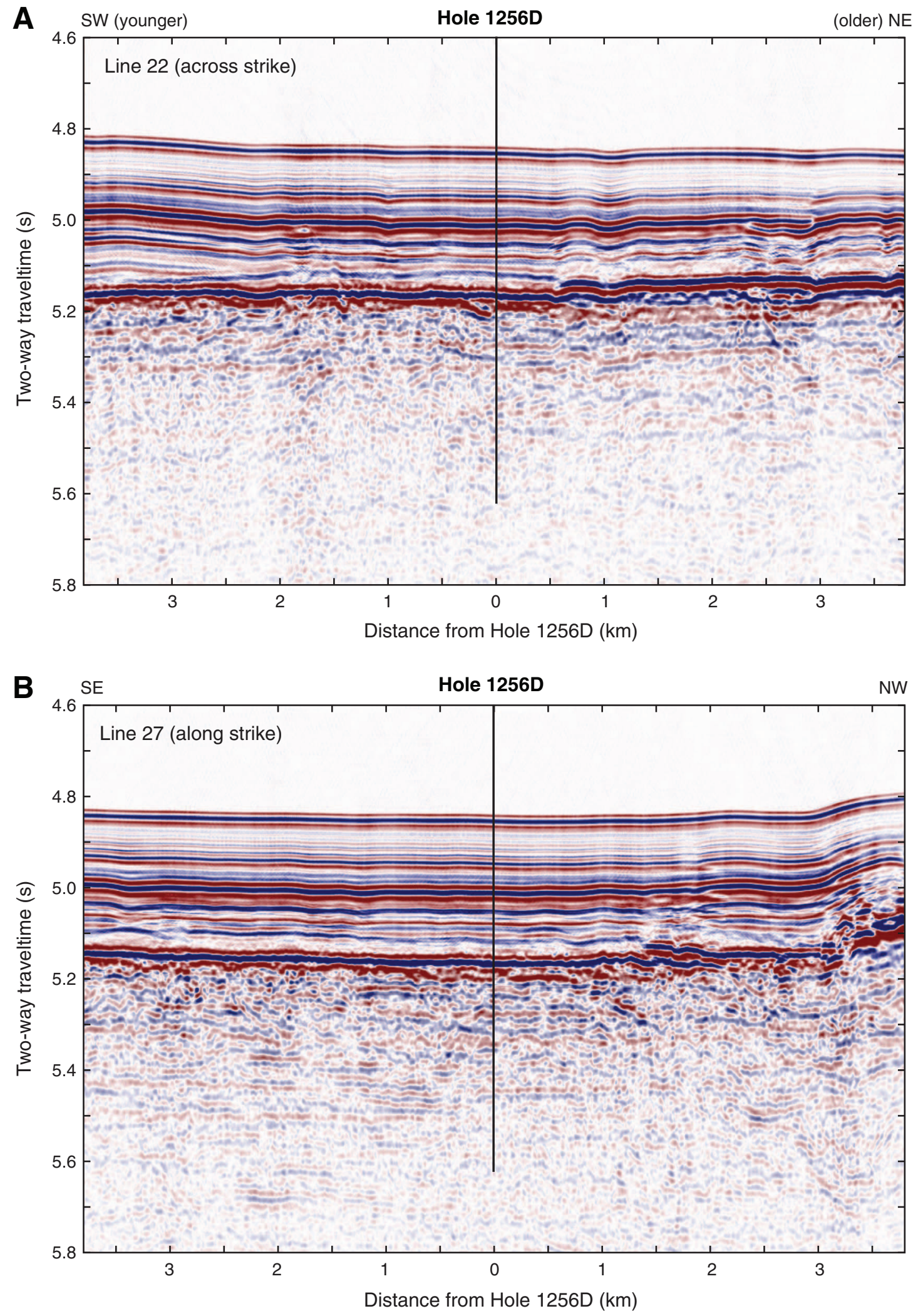
Figure F9. One-dimensional velocity model based on inversion of refraction data. At shallow depths, separate inversions were performed on northeast (NE) and southwest (SW) data subsets, with slightly faster velocities found to the northeast where abyssal hill topography is very subdued. The Layer $2 / 3$ boundary is present in the depth range 1.2-1.5 km. The velocity model of Detrick et al. (1994) for Site 504, also based on ocean bottom hydrophone refraction data, is shown for comparison. Apparent differences are dominated by differences in the inversion techniques, but the differences at $1.3-1.7 \mathrm{~km}$ may be barely above uncertainty.

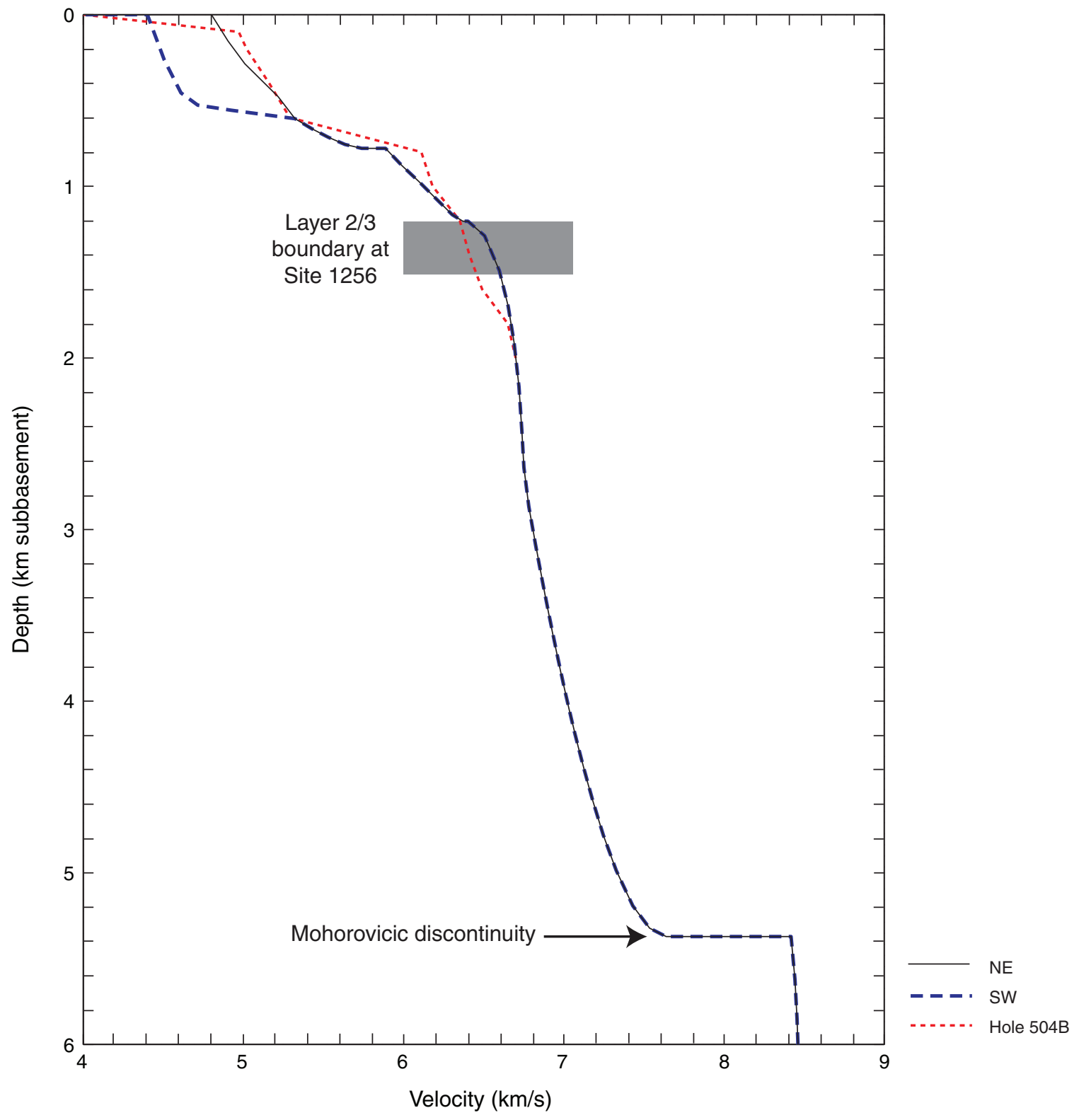


Figure F10. A. Contour map of seismic $P$-wave velocity at the top of basement, based on tomographic inversion of seismic refraction data (A.J. Harding, pers. comm., 2005). The low-velocity area west of the center may reflect pillow lavas or other porous formation. The high-velocity area extending southeast from Site 1256 may reflect the extent of the ponded lava sequence drilled at the top of Site 1256 . OBH = ocean bottom hydrophone. B. Geological sketch map of the Site 1256 area (GUATB-03) showing bathymetry, alternate site locations, and selected top-of-basement velocity contours from A. The larger velocity contour line partially encloses velocity $>4.82 \mathrm{~km} / \mathrm{s}$, which we interpret as a plausible proxy for the presence of thick ponded lava flows, as encountered at Site 1256 . The smaller contour encloses velocities $<4.60 \mathrm{~km} / \mathrm{s}$, possibly reflecting a greater portion of pillow lavas than elsewhere in the region. Alternate reentry Sites 3D and 3E are 0.5-1.0 km from Site 1256 and are not shown in the figure.
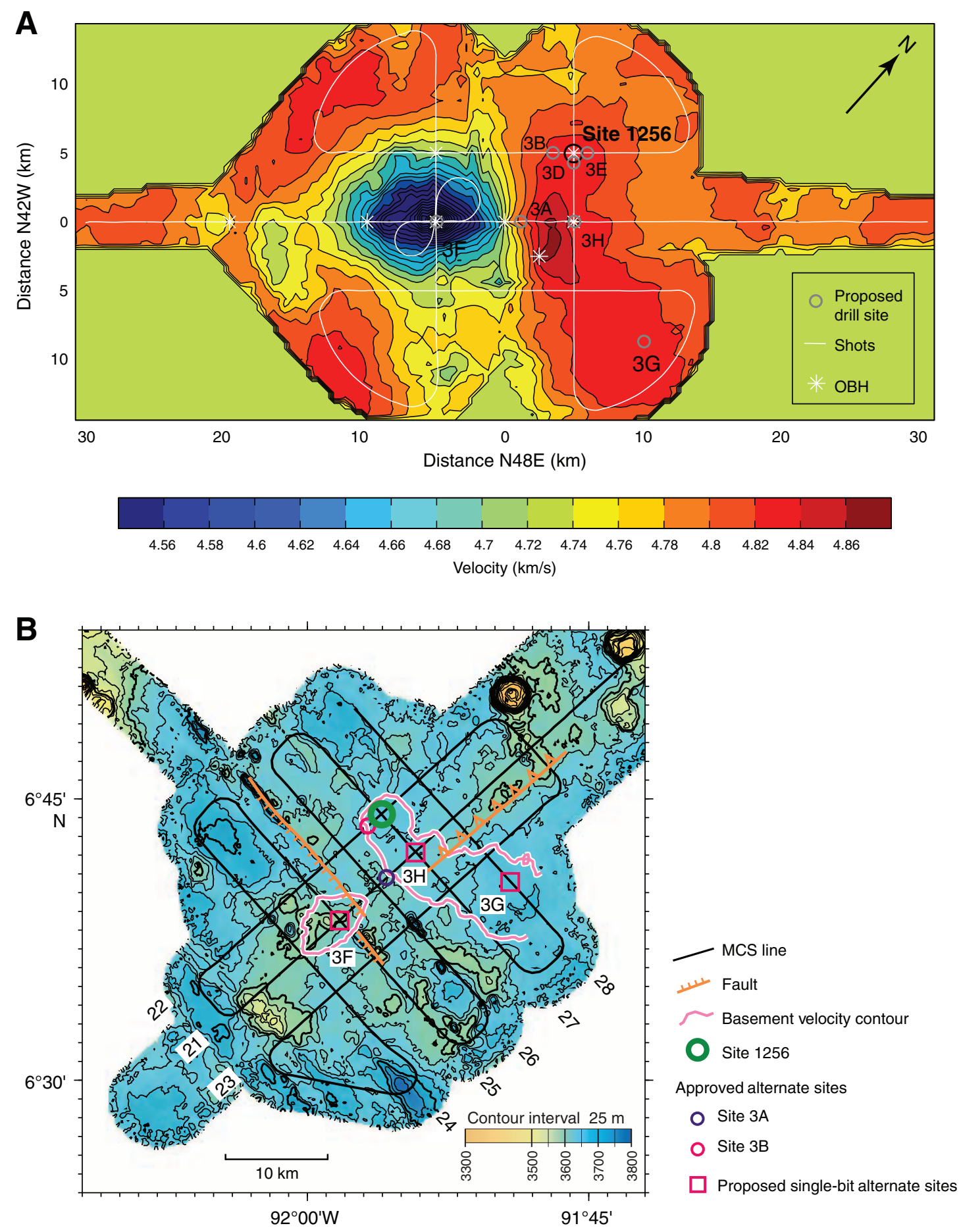
Figure F11. Measured and estimated temperatures with depth in Hole 1256D (Wilson, Teagle, Acton, et al., 2003; Teagle, Alt, Umino, Miyashita, Banerjee, Wilson, and the Expedition 309/312 Scientists, 2006). Thermal profile estimated using the measured conductive heat flow and appropriate thermal conductivities for the lava, dikes, and gabbros. Thermal data for Hole $1256 \mathrm{D}$ is compared against the stratigraphy and equilibrium temperature log for Hole 504B located on 6.9 Ma crust south of the intermediate spreading rate Costa Rica Rift. At the depth achieved in Hole $1256 \mathrm{D}$ by the end of Expedition 312, that site is estimated to be $\sim 50^{\circ}$ cooler $\left(\sim 114^{\circ} \mathrm{C}\right)$ than the temperature measured at the equivalent depth in Hole 504B $\left(\sim 163^{\circ} \mathrm{C}\right)$. The highest temperature recorded in Hole 504B was $189^{\circ} \mathrm{C}$ at $1979 \mathrm{mbsf}$ (Alt, Kinoshita, Stokking, et al., 1993). We highlight the $120^{\circ} \mathrm{C}$ isotherm, thought to be close to the limit of prokaryotic life (e.g., Heberling et al., 2010) for Holes 1256D and 504B. Hole 1256D is yet to reach this threshold, but Hole 504B is above this temperature below $\sim 800 \mathrm{mbsf}$. $\mathrm{TAP}=$ Temperature/Acceleration/Pressure tool.

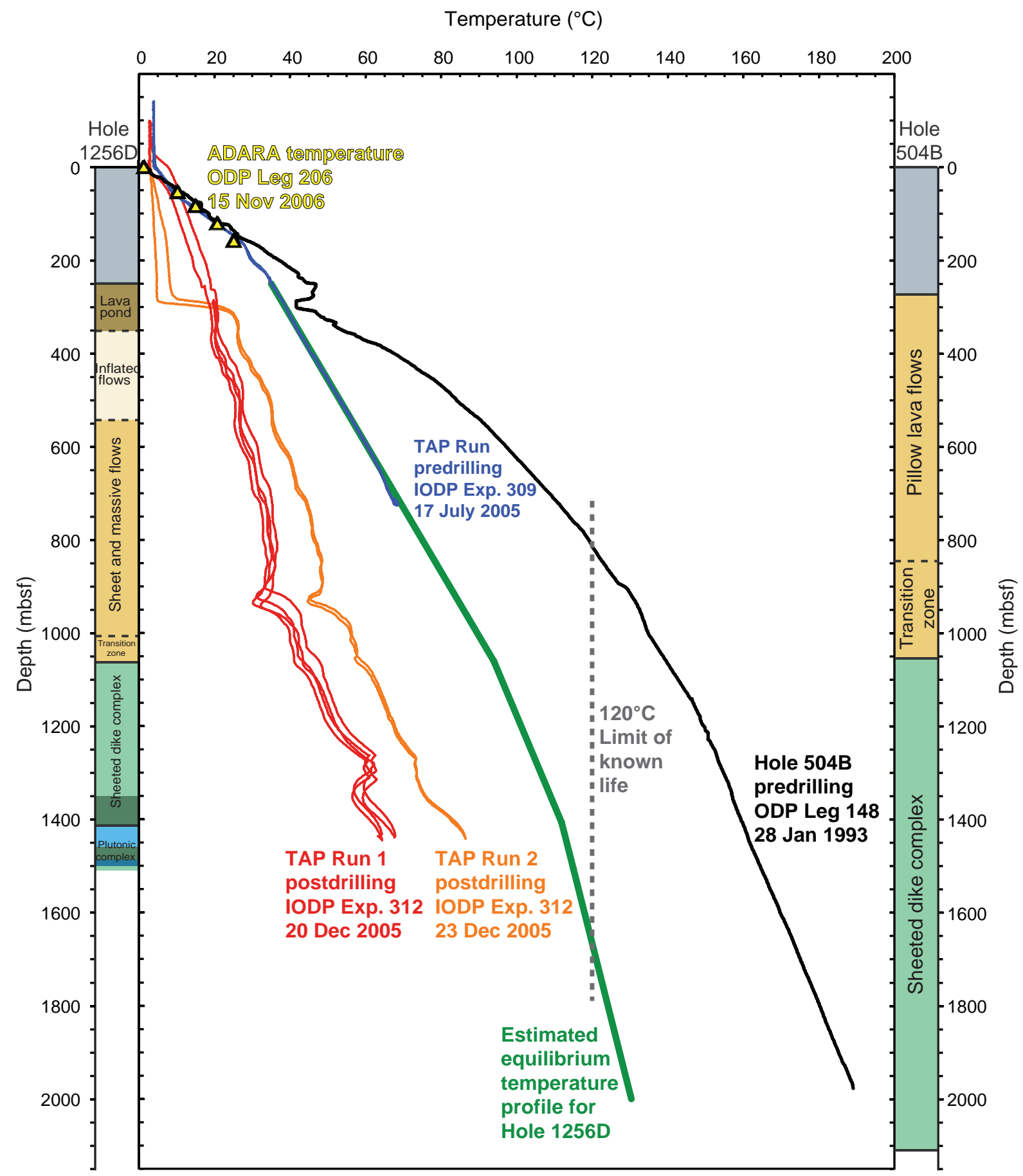


Figure F12. Summary lithostratigraphic column of the basement drilled at Site 1256 at the end of Expedition 312 showing recovery, major lithologies, downcore index alteration mineral distribution (thick lines = abundant, thin lines = rare, dashed lines = irregular; Teagle, Alt, Umino, Miyashita, Banerjee, Wilson, and the Expedition 309/312 Scientists, 2006, updated by Alt et al., 2010), downcore distribution of Mg\# (where Mg\# = $100 \times \mathrm{Mg} /[\mathrm{Mg}+0.9 \times \mathrm{Fe}]$ ) atomic ratio (symbols follow colors in the lithostratigraphic column), and seismic velocity measured on discrete samples from wireline tools (Wilson, Teagle, Acton, et al., 2003; Teagle, Alt, Umino, Miyashita, Banerjee, Wilson, and the Expedition 309/312 Scientists, 2006; reprocessed data from Guérin et al., 2008) and from seismic refraction data (Wilson et al., 2003). Heavy red and orange lines show the inversion of traveltimes from Leg 206 and Expedition 312 vertical seismic profiles (VSPs), respectively (Swift et al., 2008).

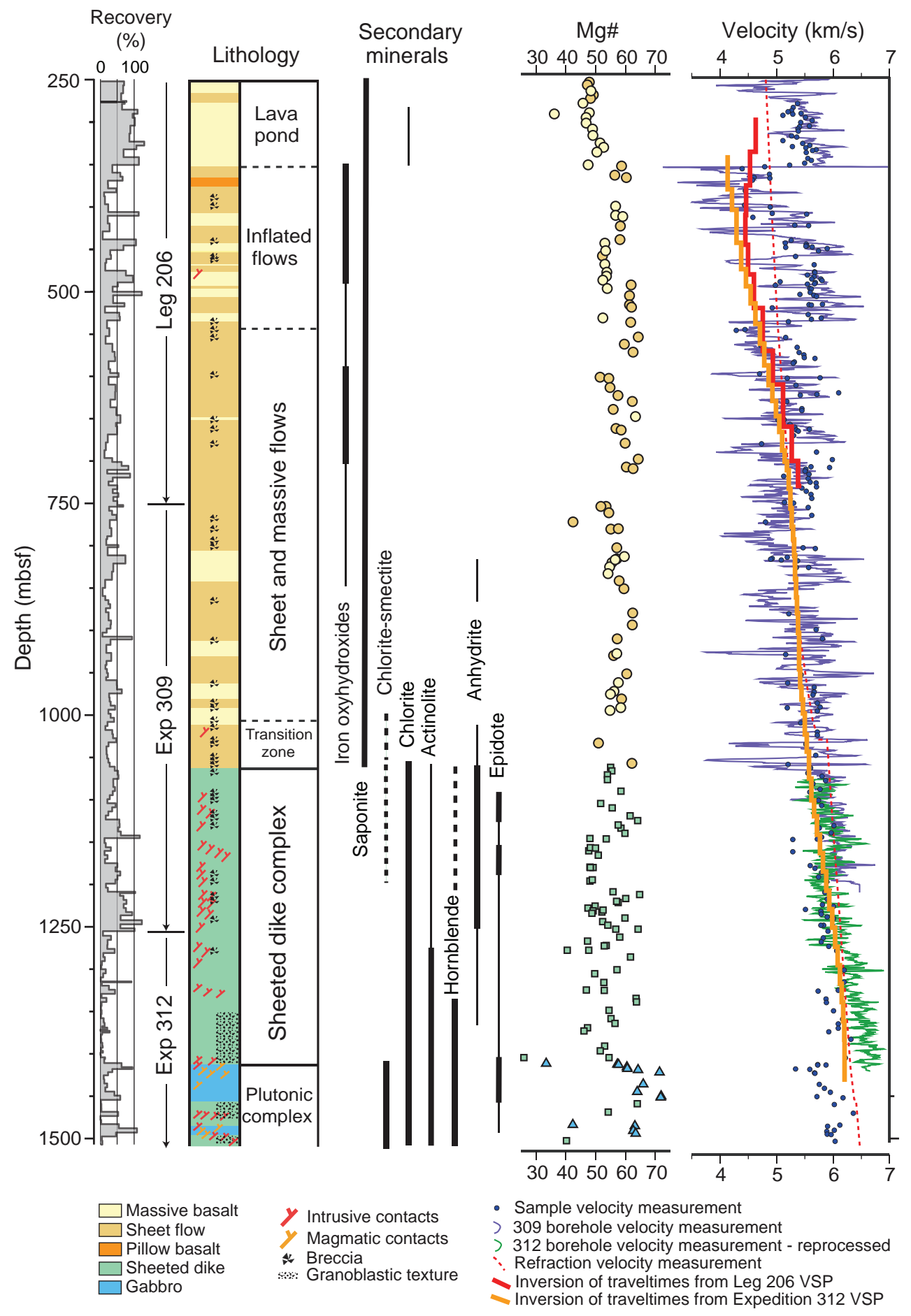


Figure F13. Plutonic section from the lower portion of Hole 1256D with representative photomicrographs of key samples. A. Schematic lithostratigraphy. The distribution of rock types is expanded proportionately in zones of incomplete recovery. Felsic plutonic rocks include quartz-rich oxide diorite and trondhjemite. OPX = orthopyroxene. B. Photomicrograph of a dike completely recrystallized to a granoblastic association of equant secondary plagioclase, clinopyroxene, magnetite, and ilmenite. Some granoblastic dikes have minor orthopyroxene. C. Photograph of dike/gabbro boundary. Medium-grained oxide gabbro is intruded into a granoblastically recrystallized dike along an irregular, moderately dipping contact. The gabbro is strongly hydrothermally altered. D. Quartz-rich oxide diorite strongly altered to actinolitic hornblende, secondary plagioclase, epidote, and chlorite. Epidote occurs in $\sim 5 \mathrm{~mm}$ clots in the finer grained leucocratic portions of the rock. E. Disseminated oxide gabbro with patchy texture and centimeter-scale dark ophitically intergrown clinopyroxene and plagioclase patches separated by irregular, more highly altered leucocratic zones. F. Medium-grained strongly hydrothermally altered gabbro. The sample is cut by several chlorite + actinolite veins with light gray halos. Plagioclase is replaced by secondary plagioclase and clinopyroxene by amphibole. G. Clast of partially resorbed dike within gabbro. (Figure shown on next page.) 
Figure F13 (continued). (Caption shown on previous page.)

A

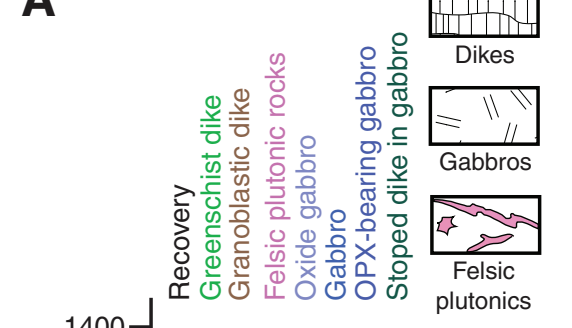

政

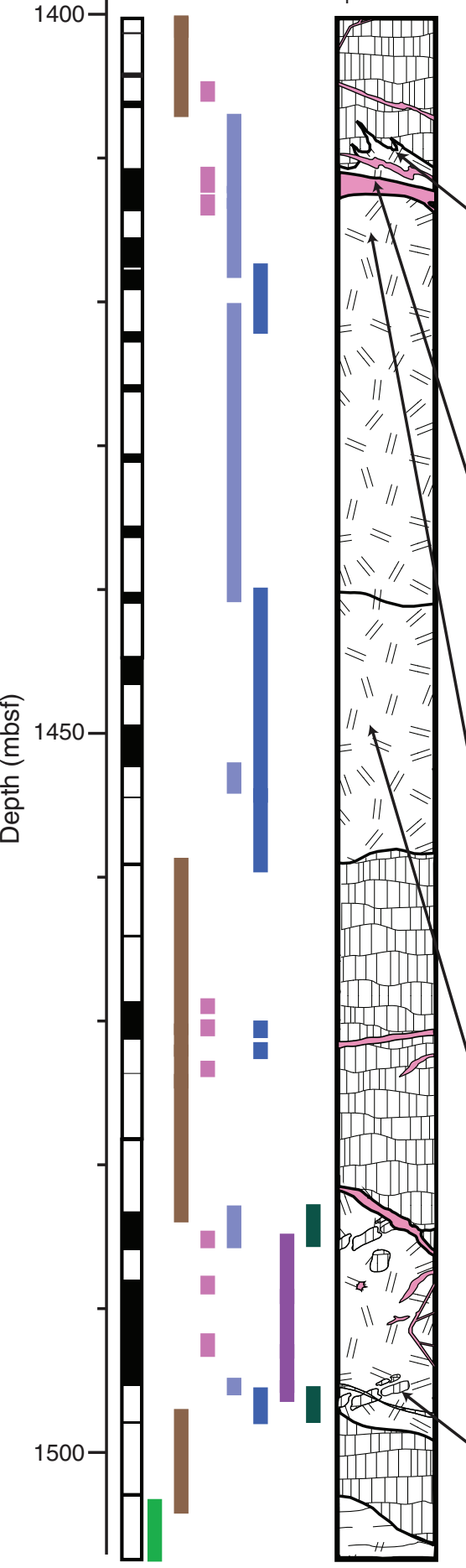

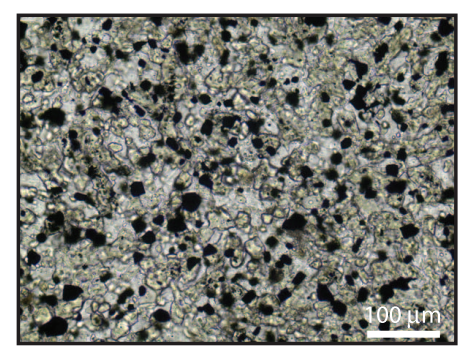

B 205R-1, 10-14 cm; $1382 \mathrm{mbsf}$

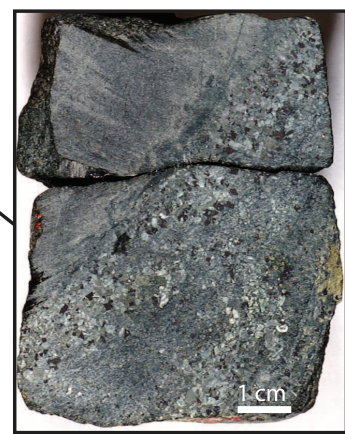

C 213R-1, 52-60 cm; $1407 \mathrm{mbsf}$

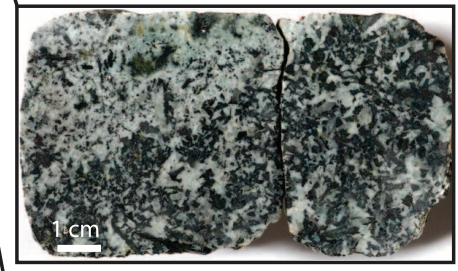

D 214R-1, 48-58 cm; $1411 \mathrm{mbsf}$

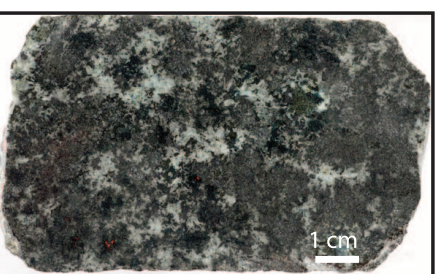

E 214R-2, 61-70 cm; $1413 \mathrm{mbsf}$

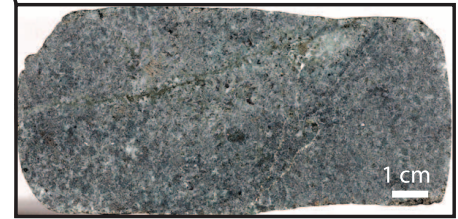

F 223R-3, 12-24 cm; $1452 \mathrm{mbsf}$

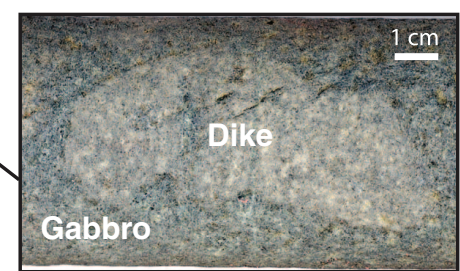

G 232R-2, 32-46 cm; 1494 mbsf 
Figure F14. $\mathrm{FeO}^{\top}$ (Total Fe expressed as $\mathrm{FeO}$ ) vs. $\mathrm{MgO}$ for the basement at Site 1256, compared with analyses of northern East Pacific Rise (EPR) (outline, Langmuir et al., 1986). Dashed lines show constant Mg\#. Possible primary mantle melt compositions should have Mg\# of 70-78 and $\mathrm{MgO}$ of 9-14 wt\%. All flows and dikes, and most gabbros, are too evolved to be candidates for primary magmas.

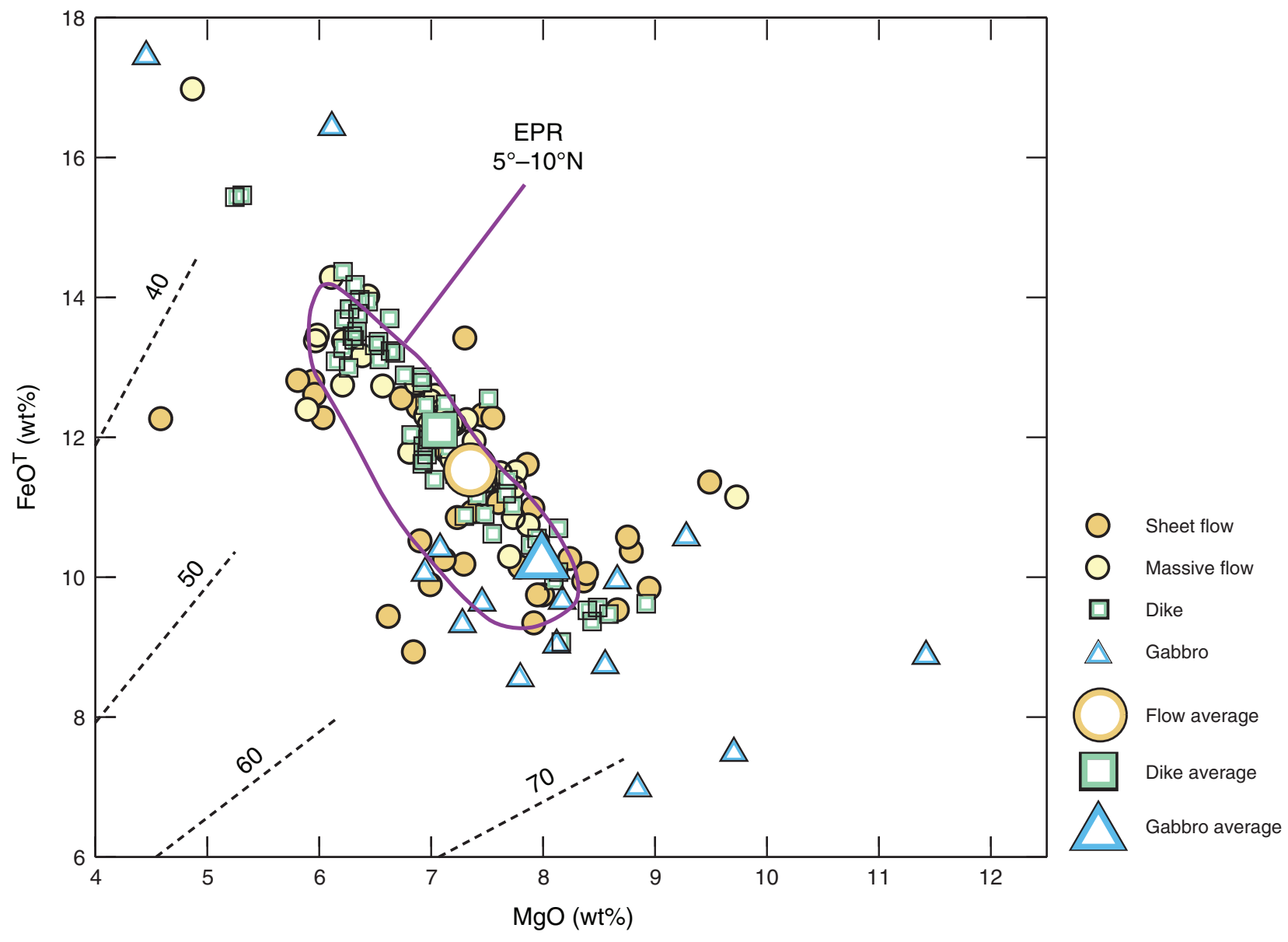


Figure F15. East Pacific Rise (EPR) mid-ocean-ridge basalt (MORB)-normalized multielement plot of the average of different lithologic subdivisions from Hole 1256D. LP = lava pond, $\mathrm{MF}=$ massive flow, $\mathrm{SF}=$ sheet flow, $\mathrm{BD}=$ basalt dike, G1 = Gabbro 1, G2 = Gabbro 2. EPR values of Y, Sr, Zr, and TiO2 are taken from Su and Langmuir et al. (2003). Other elements are compiled from PETDB (www.petdb.org/) for basalts with $\mathrm{MgO}>6.0 \mathrm{wt} \%$.

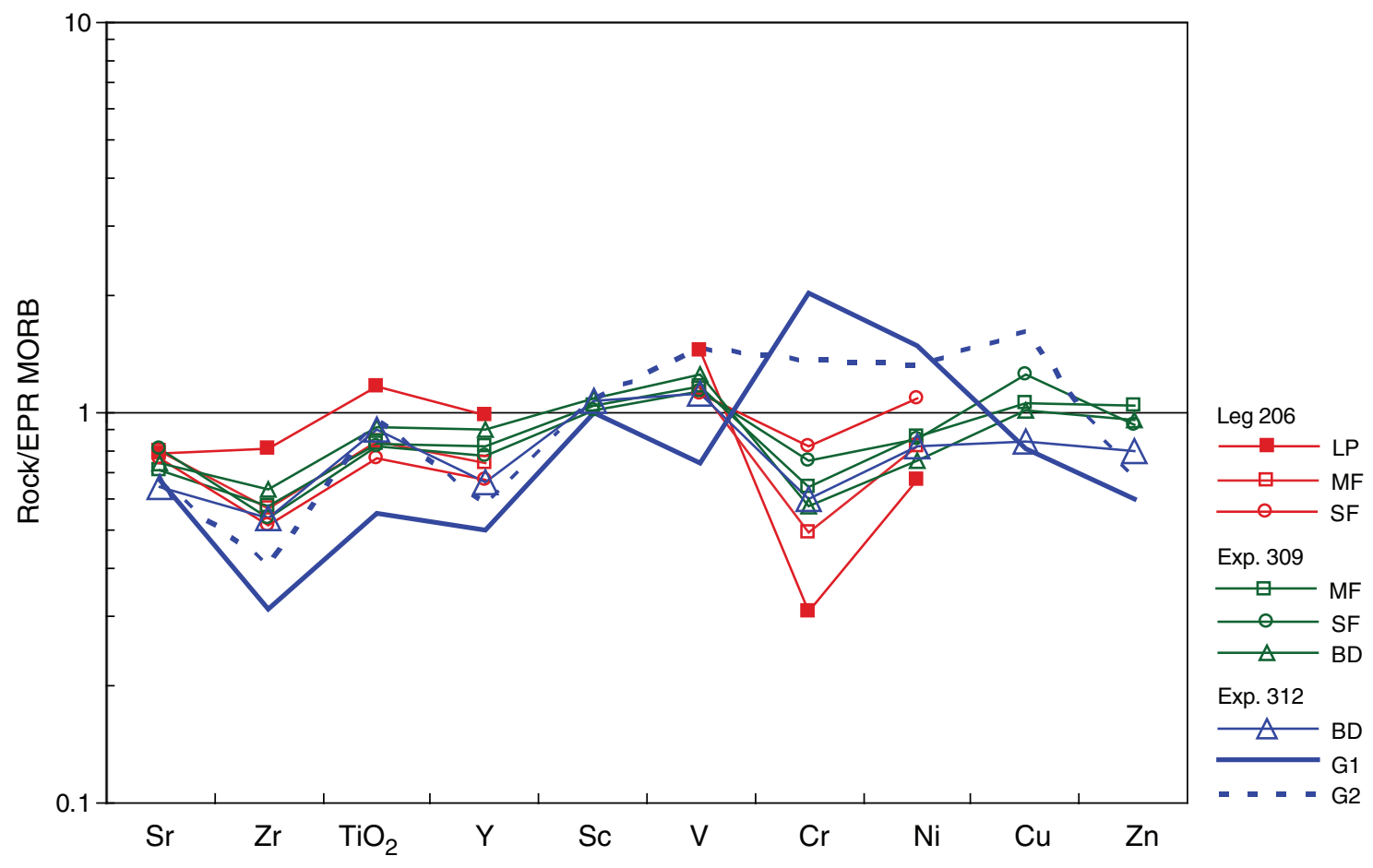


Figure F16. A. Predicted lithostratigraphy of the Site 1256 crust based on geological observations from the Oman ophiolite. B. Field photograph showing the intrusive contact of gabbro with sheeted dikes at the sheeted dike-gabbro transition (Aswad, Sumail massif). C. Field photograph of varitextured gabbros from a few meters below the dike-gabbro transition (Wadi Gideah, Wadi Tayin Massif). D. Field photograph of subvertically foliated cumulate gabbros from the upper gabbro section (Aswad, Sumail Massif). E. Field photograph of Mohoparallel modally layered cumulate gabbros (Samrah, Sumail Massif); layers are $\sim 30$ to $60 \mathrm{~cm}$ thick.

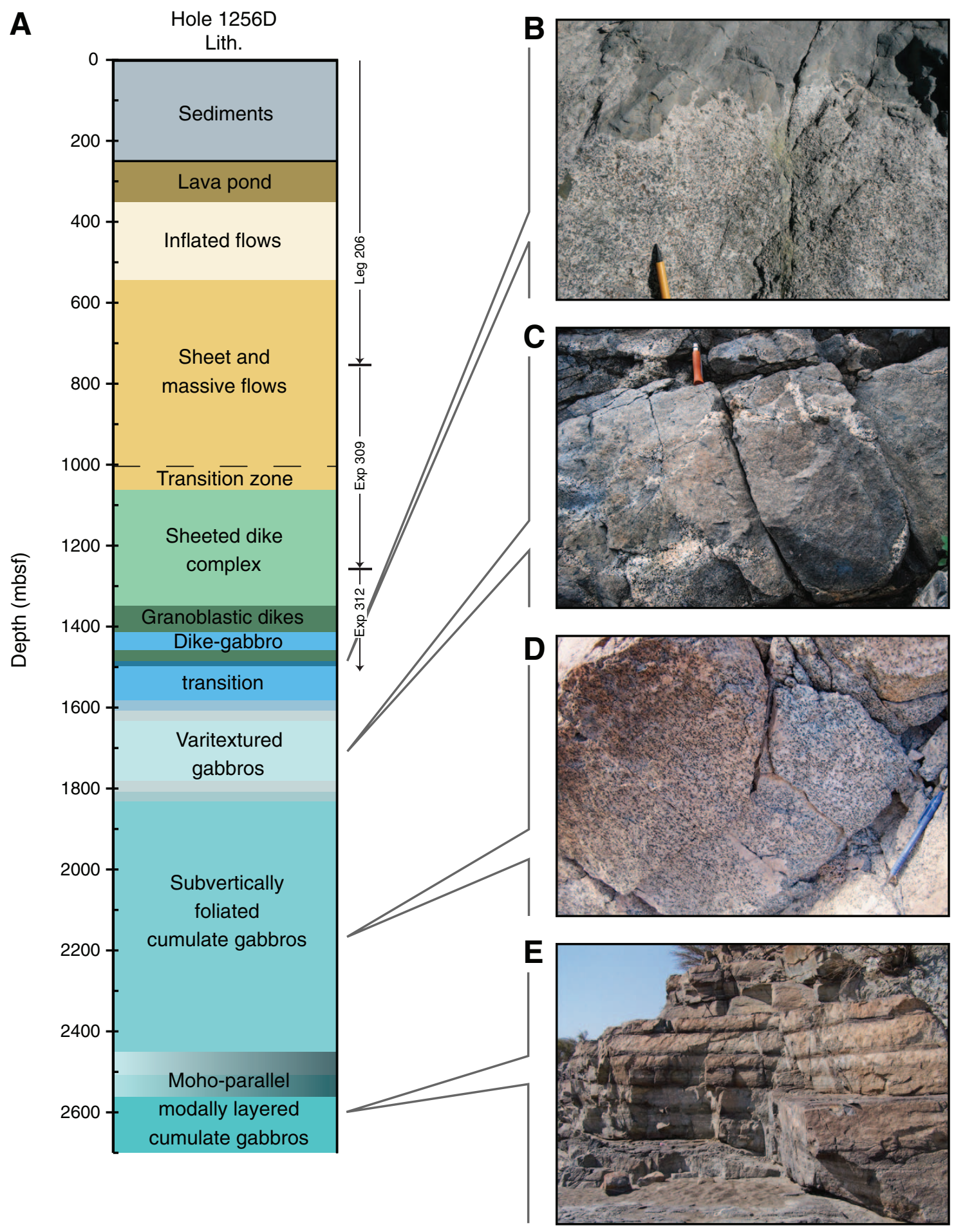


Figure 17. Schematic drawings of crustal accretion models (modified from Korenaga and Kelemen, 1997). Black arrows show the movement of the solid lower crust; blue arrows show the dominant zones where hydrothermal circulation will remove latent and sensible heat; red arrows show the movement of magma-this is unknown in all models. A. Gabbro glacier ductile flow model (e.g., Henstock et al., 1993; Phipps Morgan and Chen, 1993; Quick and Denlinger, 1993). Ductile flow down and outward from a high-level axial magma chamber constructs the lower crust. B. Hybrid model of ductile flow with sill intrusions (e.g., Boudier et al., 1996). C. "Sheeted" or "stacked" sill model of in situ formation of the lower crust by on-axis sill intrusions (e.g., Bédard et al., 1988; Kelemen and Aharonov, 1998; Kelemen et al., 1997; MacLeod and Yoauancq, 2000). D. Schematic relative variations in the general trends of latent heat release, bulk Mg\#, strain rate, cooling rate, hydrothermal fluid flux, fluid temperature, and intensity of high-temperature (HT) alteration with depth predicted by end-member "gabbro glacier" (with mainly conductive cooling of the lower crust) and "sheeted sill" (with convective cooling of the lower crust) models of crustal accretion (original figure by R. Coggon).
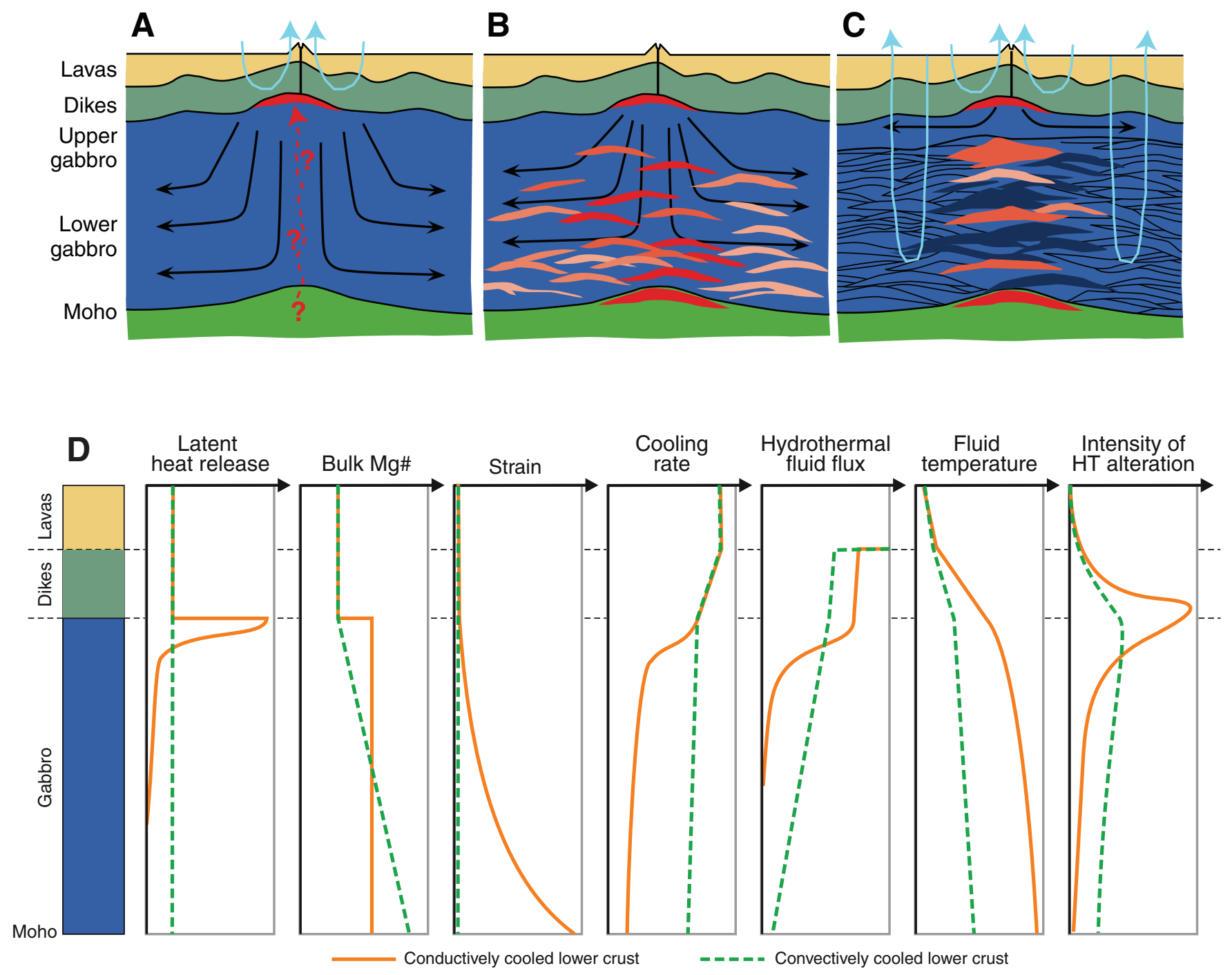
Figure F18. Average core recovery and rate of penetration for drilling in Hole 1256D during Leg 206 and Expedition 309/312. Note the improvement in both parameters in gabbroic rocks back to near average rates for the entire hole ( $\sim 36 \%$ recovery; $1.2 \mathrm{~m} / \mathrm{h}$ penetration rate). Recovery was very low and penetration rate excruciatingly slow in the granoblastic dikes. $\mathrm{ROP}=$ rate of penetration.

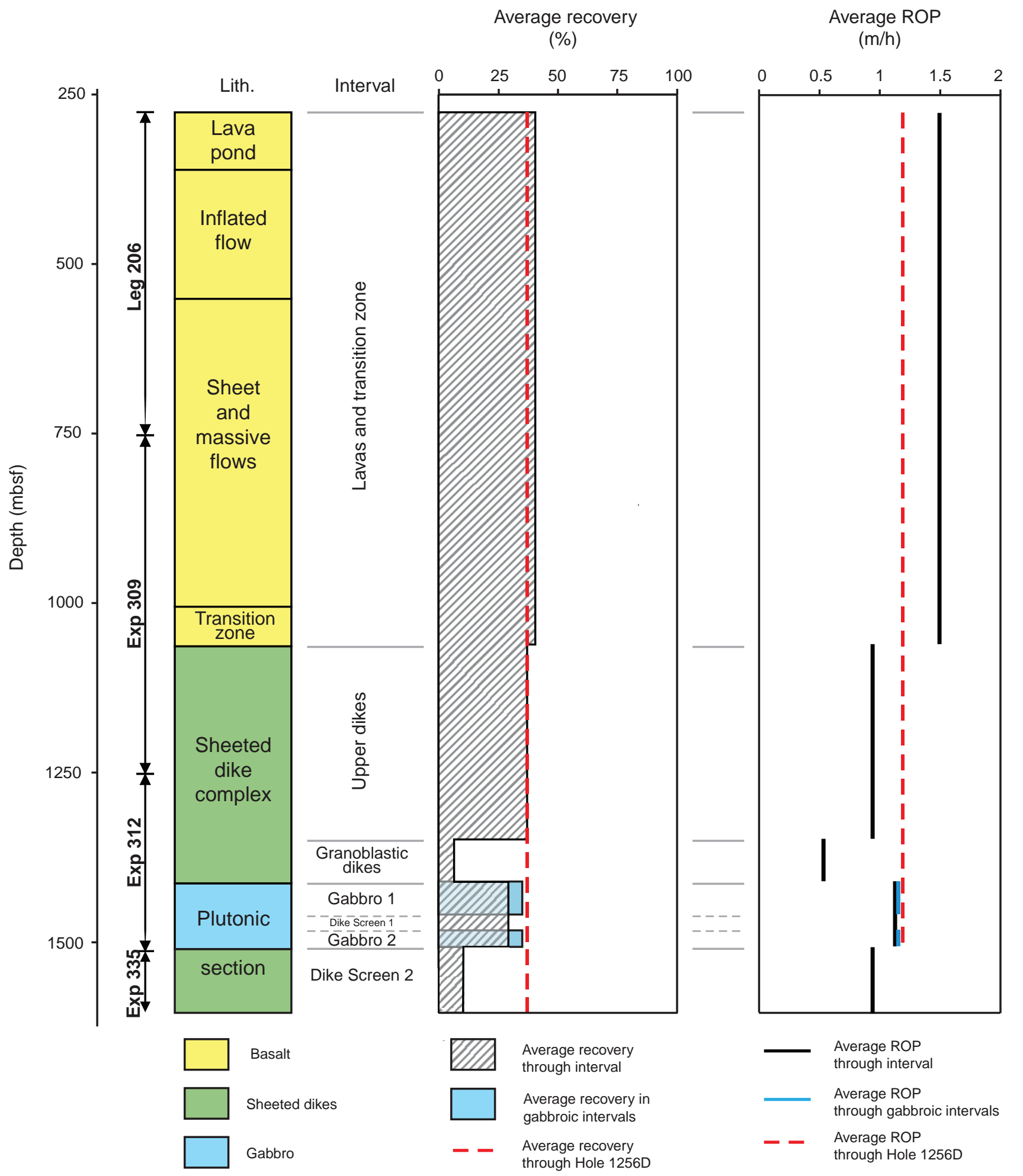


Figure F19. Photographs of various coring, drilling, fishing, and milling tools used during Expedition 335, illustrating some of the multiple operation events reported in "Operations" A. Smith 9 inch F9 tricone bit used for Run 1 to work the obstruction between 920 and 925 mbsf; teeth were not worn, and much of the work was on the outside faces. B. Reed 9 inch tricone bit (IADC Type 517) used for Run 2. Note the more aggressive cutting structure of this bit compared to the first one. Again, after working the obstructed interval between 920 and $923 \mathrm{mbsf}$, the cones underwent very little damage, except for a couple of missing teeth. C. After Runs 35, dedicated to working further and cementing the interval between 882 and 922 mbsf, this 9 inch Atlas HP61 tricone bit was used during Run 6 to drill through cement and again work the obstructed interval at 922-923 mbsf. It returned in good condition with no appreciable shirttail wear, with all teeth intact and exhibiting very little wear. D. One of the two external junk baskets (EXJBs) run together with the tricone of E during Run 6; the two EXJBs returned basalt fine-grained cuttings and pebbles. (Continued on next 10 pages.)
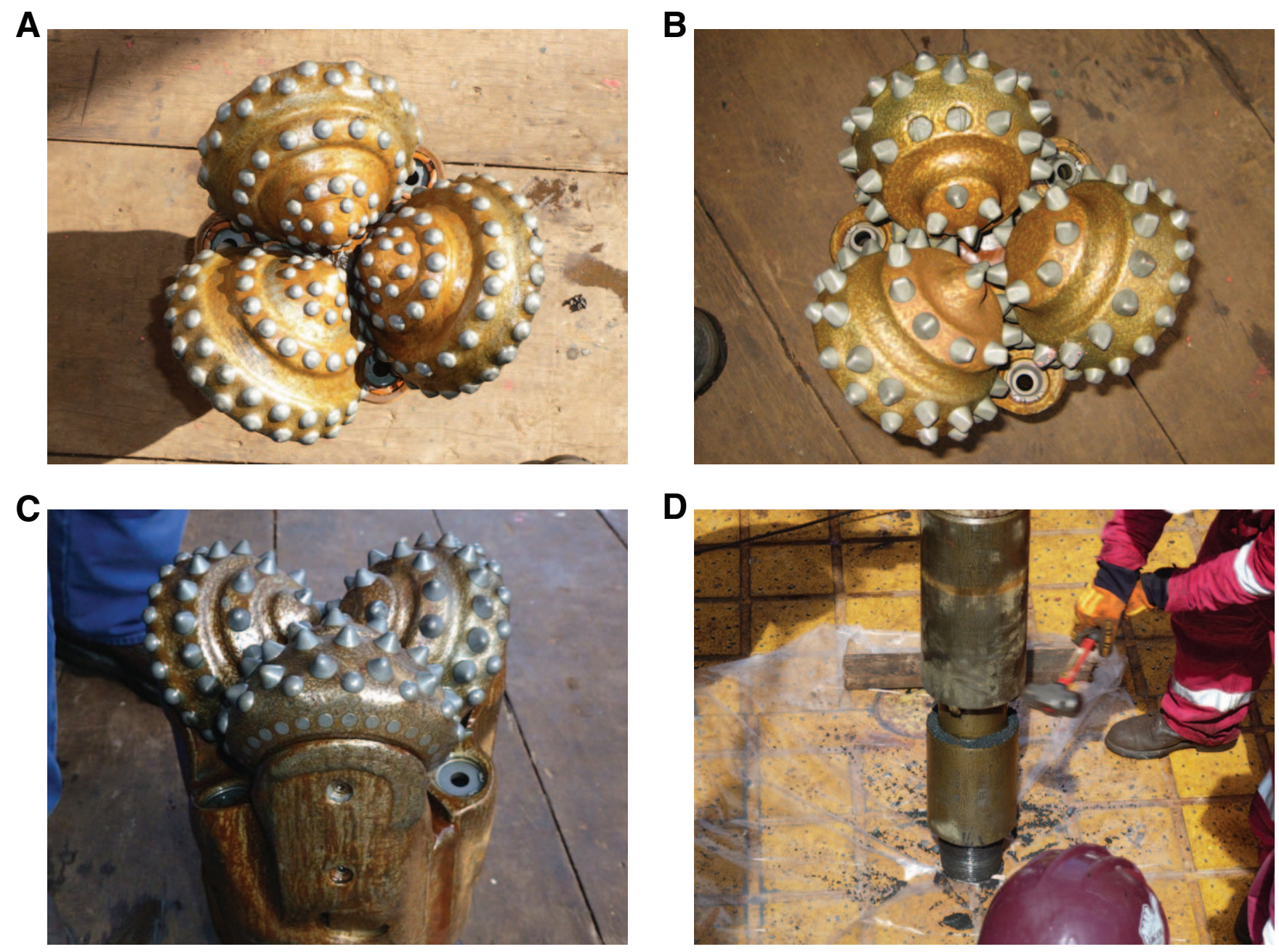
Figure F19 (continued). E. Smith 9 inch tricone bit used for Run 7 to successfully clear the obstructed interval at 922-923 mbsf and work several ledges before reaching the bottom of the hole on the morning of 1 May. The bit was slightly out of gauge after $32.8 \mathrm{~h}$ of use. F. The worn core catcher used during Run 9, the first coring run of Expedition 335. As drilling continued for $\sim 10 \mathrm{~h}$ with a destroyed bit $(\mathrm{G}, \mathrm{H})$, the core catcher was in contact with metal/junk and/or rocks; it is $\sim 1 \mathrm{~cm}$ shorter than the new core catcher on the right. $\mathbf{G}, \mathrm{H}$. Remains of the Ulterra C9 rotary core barrel coring bit used during Run 9. The bit was probably used for $\sim 10 \mathrm{~h}$ after it disintegrated, which resulted in this spectacularly abraded and sculptured bit ("Stumpy"), something never seen before by the drillers. (Continued on next page.)

E

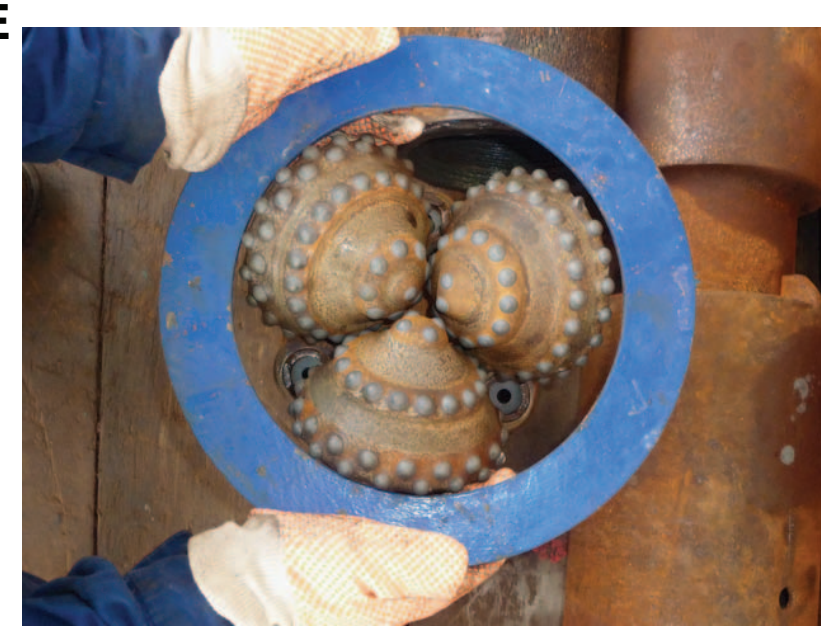

G

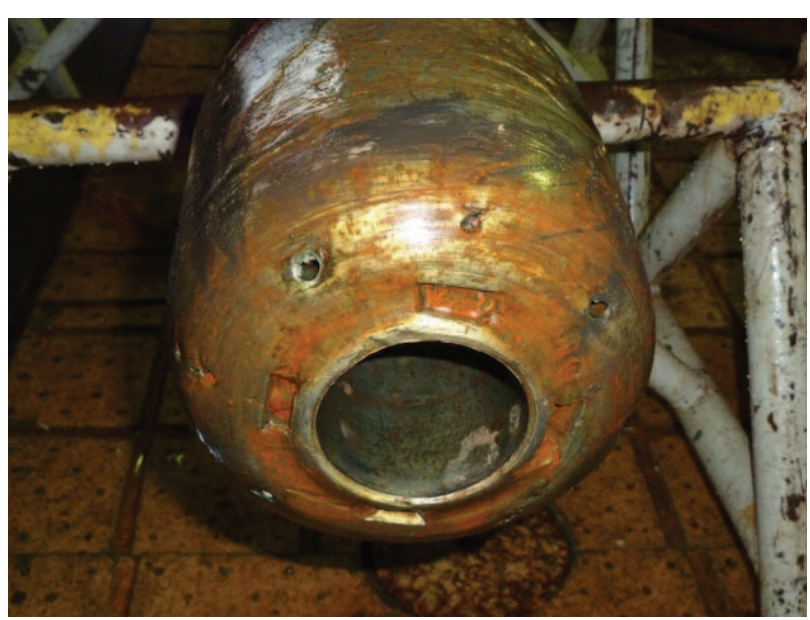

$\mathbf{F}$

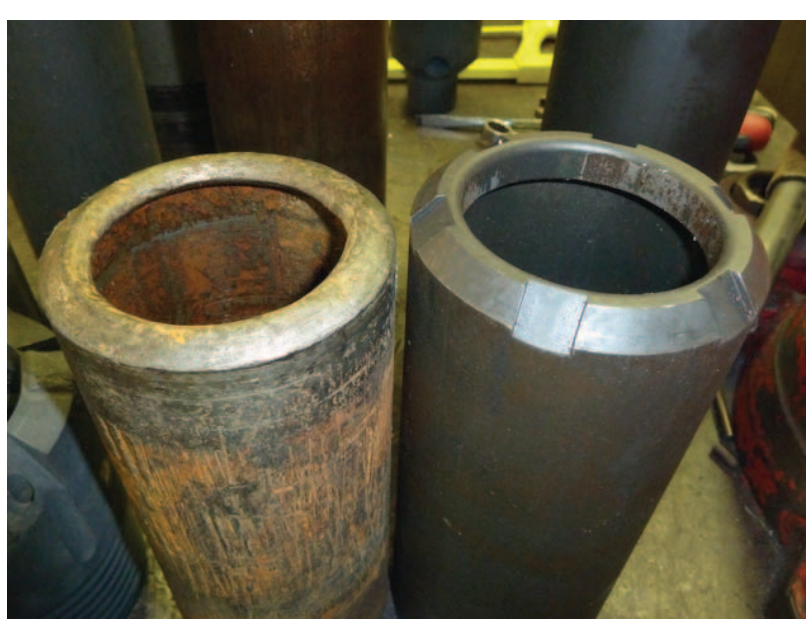

H

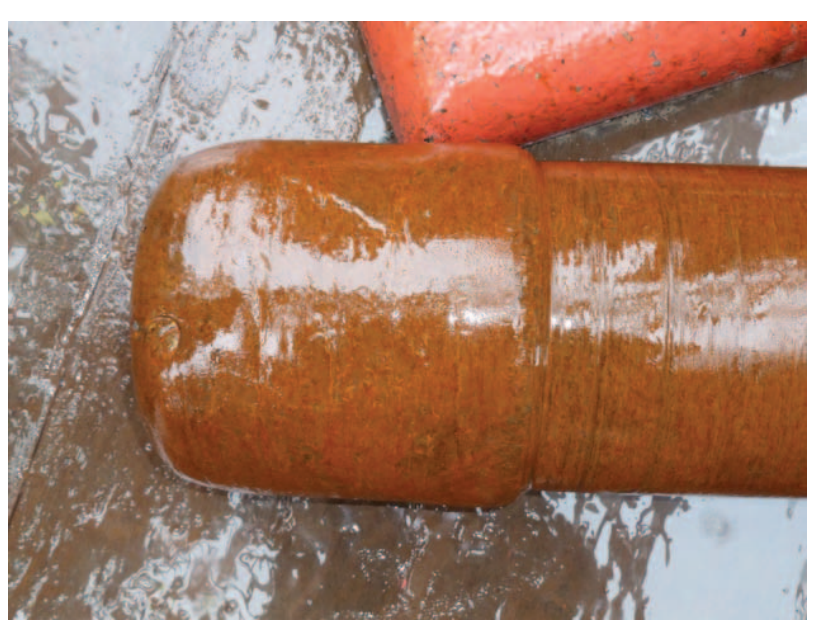


Figure F19 (continued). I. The 9 inch Bowen fishing magnet used for Run 10. J. The fishing magnet could not be deployed all the way to the bottom of the hole, as increased pump pressure indicated loss of circulation at 1434 mbsf. When back on the rig floor, $4 \mathrm{~m}$ of fine-grained cuttings were found inside the bit sub and the two junk baskets. This marked the beginning of a series of fishing runs, which eventually cleared the hole of a massive amount of fine-grained sandlike cuttings. K. The fishing magnet recovered a limited amount of smallsized metallic debris mixed with fine basaltic grains. L. One of the EXJBs used for Run 11 in conjunction with an Atlas 9 inch HP61 tricone bit. (Continued on next page.)

I

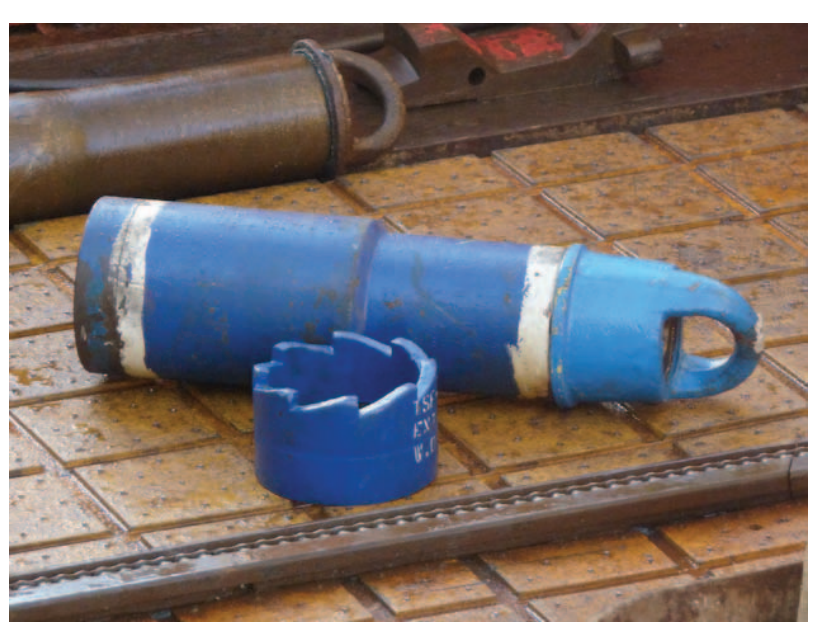

K

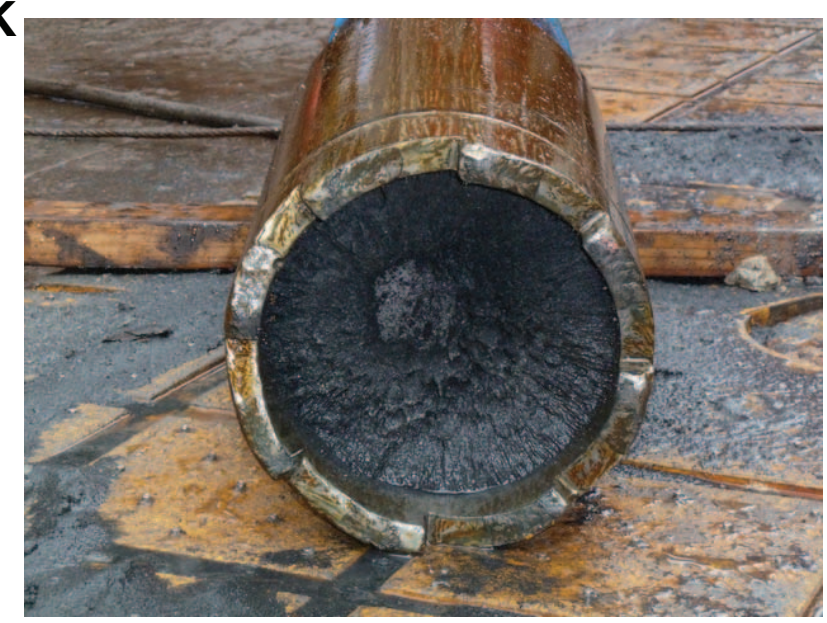

$\mathbf{J}$

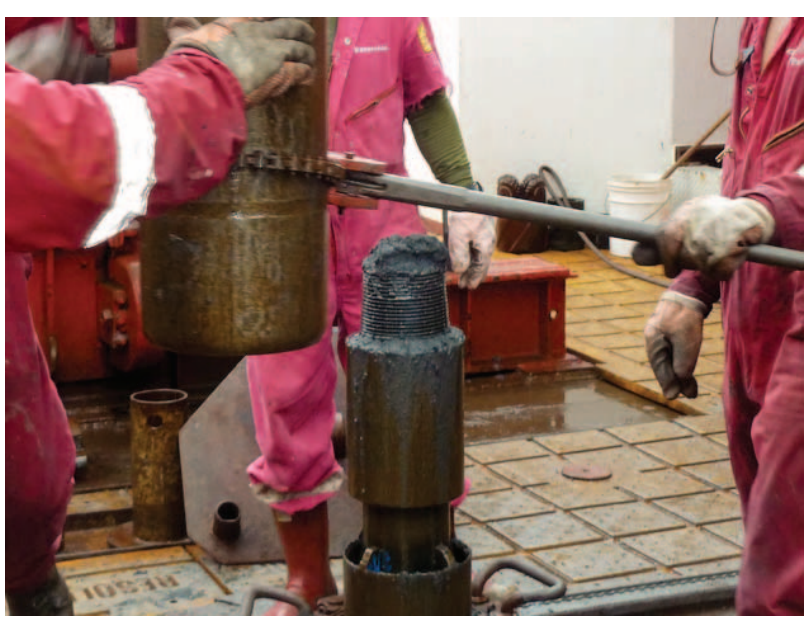

L

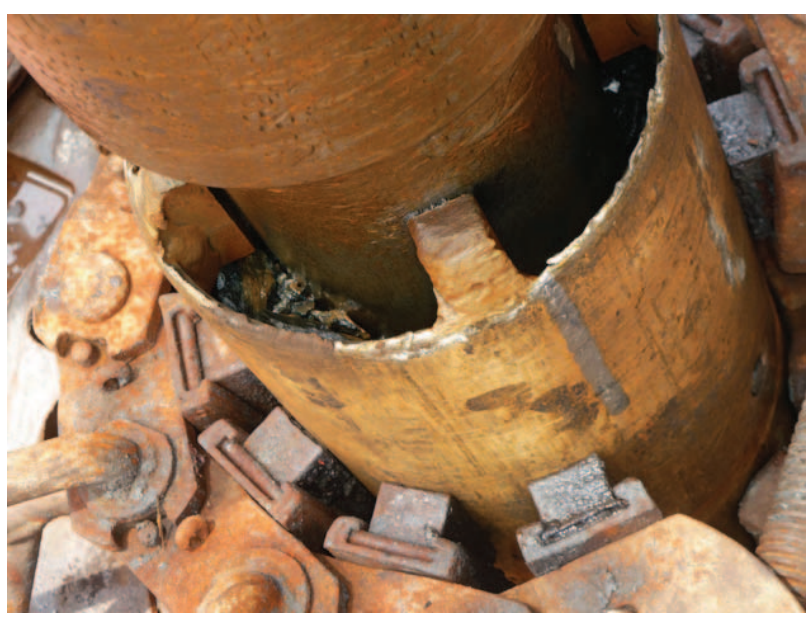


Figure F19 (continued). M. The junk baskets used for Run 11 recovered fine-grained cuttings to large pieces of rock, mostly granoblastic basalt, and some small gabbro chips. N. Bowen 9.75 inch reverse circulation junk basket (RCJB) used for Runs 12 and 13. Once reverse circulation is activated (S), water flows outside the tool through the jets visible in $\mathrm{N}$ and returns upward through the center of the tool, where a large junk catcher retains the fished material $(\mathrm{O})$. O. Bottom of the Bowen RCJB, showing its hard-facing structure and the junk catcher spring fingers inside. P. The entire bottom-hole assembly (BHA) used for Run 12, up to the top drill collar, returned completely filled with several hundreds of kilograms of fine-grained cuttings. (Continued on next page.)
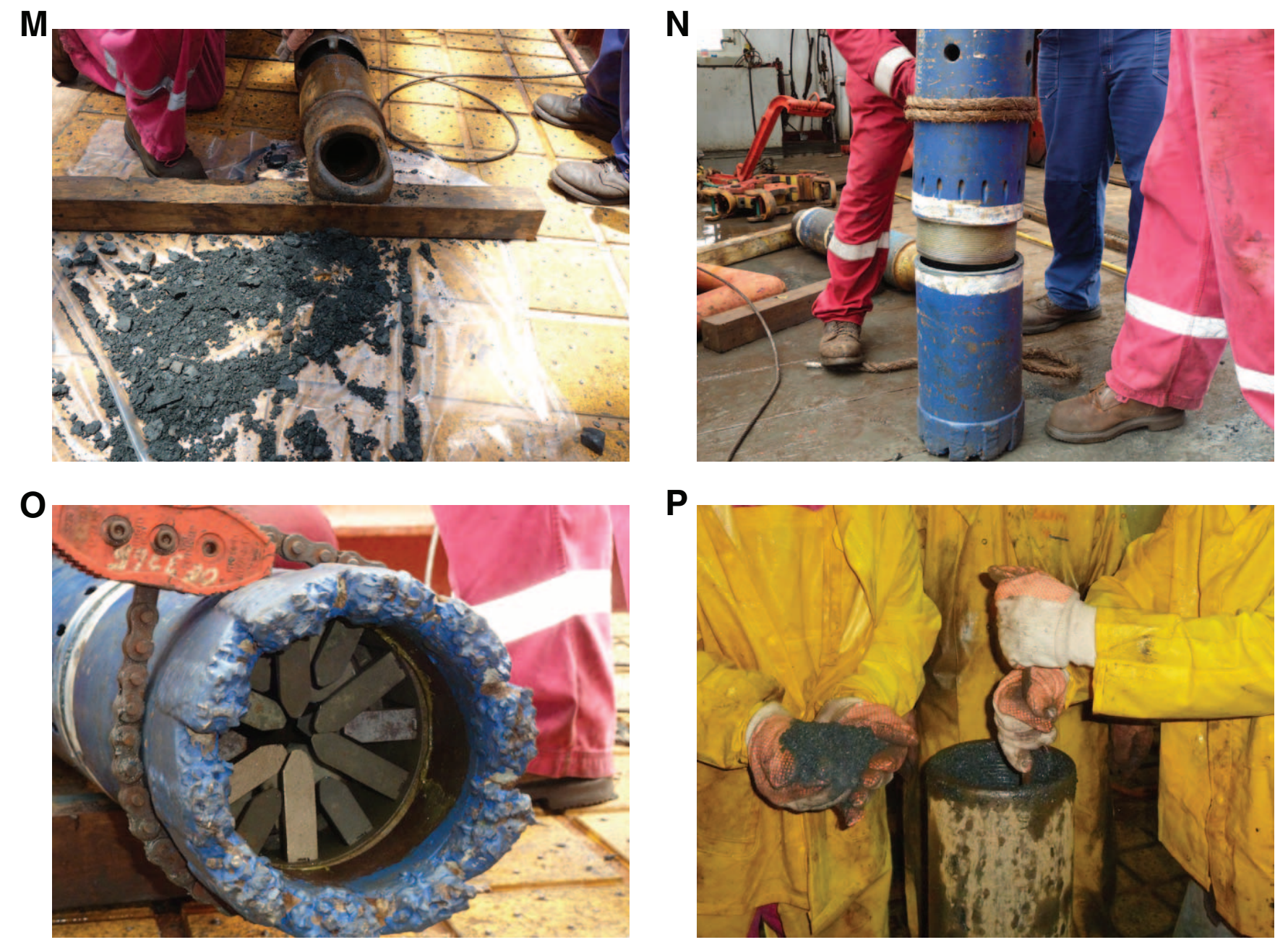
Figure F19 (continued). Q, R. The RCJB returned from Run 12 completely filled with packed cuttings and 20 $\mathrm{kg}$ of rock samples, mostly granoblastic basalt. Note the heavily worn hard-facing structure of the tool after going through $\sim 2.5 \mathrm{~m}$ of fill at the bottom of the hole. S. Top of the Bowen RCJB, showing the stainless steel ball dropped from the rig floor to activate reverse circulation by plugging the central throat and diverging fluid flow to the jets that are visible on the outside face of the tool in N. T. The second RCJB run (13) also returned a BHA packed by fine-grained cuttings and granoblastic basalt pebbles and large cobbles. (Continued on next page.)
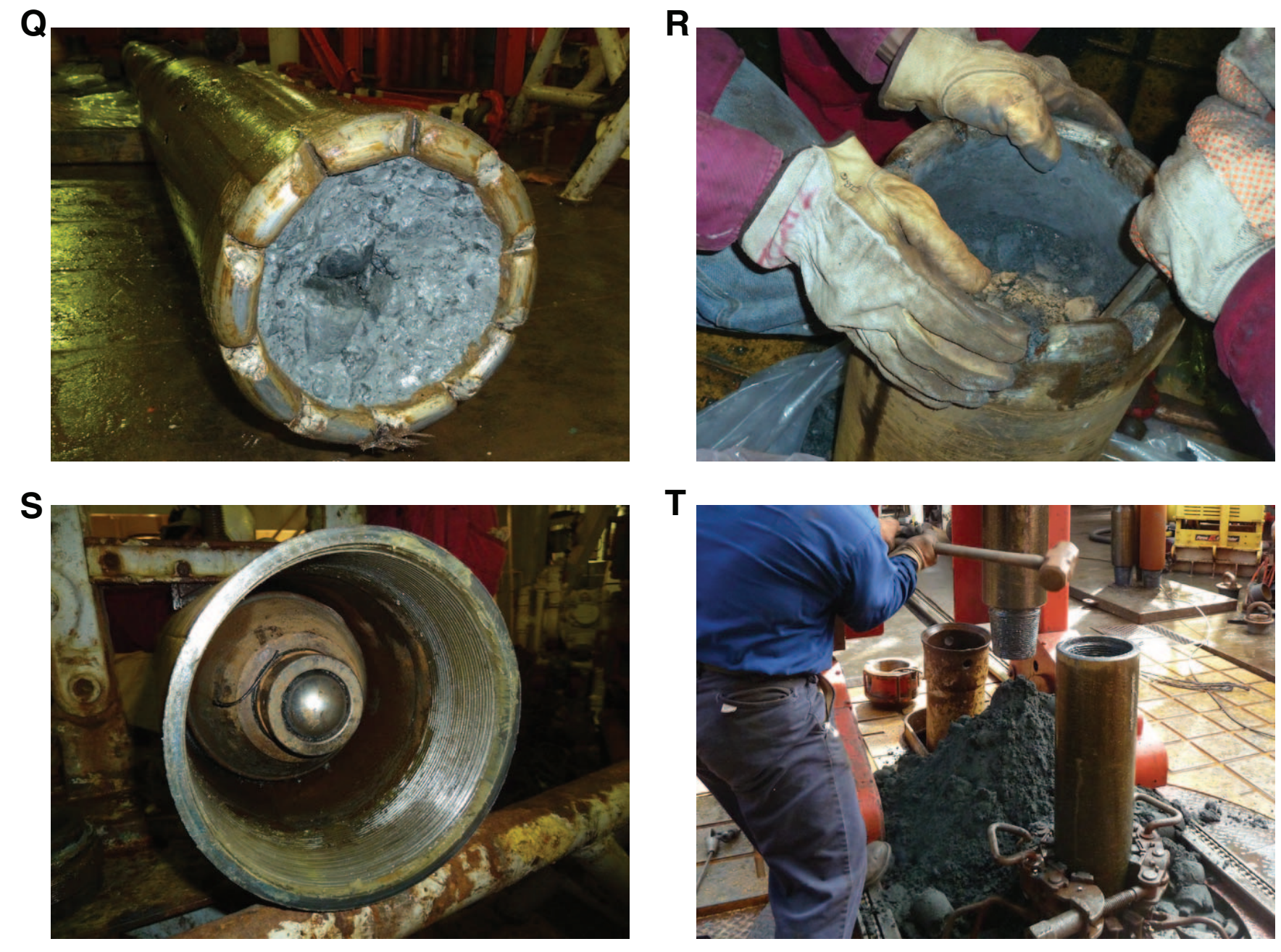
Figure F19 (continued). U. Bottom of the Homco 9.75 inch flow-through junk basket (FTJB) used for Run 14. V. The FTJB (Run 14) returned to the rig floor with a completely worn hard-facing structure, all fingers (but one) of the lowermost row of the junk catcher missing, and two large cobbles of granoblastic basalt. W. The Smith hard formation 9 inch 7JS tricone bit used in Run 15 to work the lowermost 2-3 $\mathrm{m}$ of the hole returned to the rig floor with cone bearings still tight and no worn teeth. The bit was severely under gauge (0.4 inches) with some shirttail wear and minor junk damage on its body $(\mathrm{Y})$, indicating that the lowermost portion of the hole was under gauge. X. EXJB used during Run 15, showing significant damage on the edge of one of its pockets. (Continued on next page.)
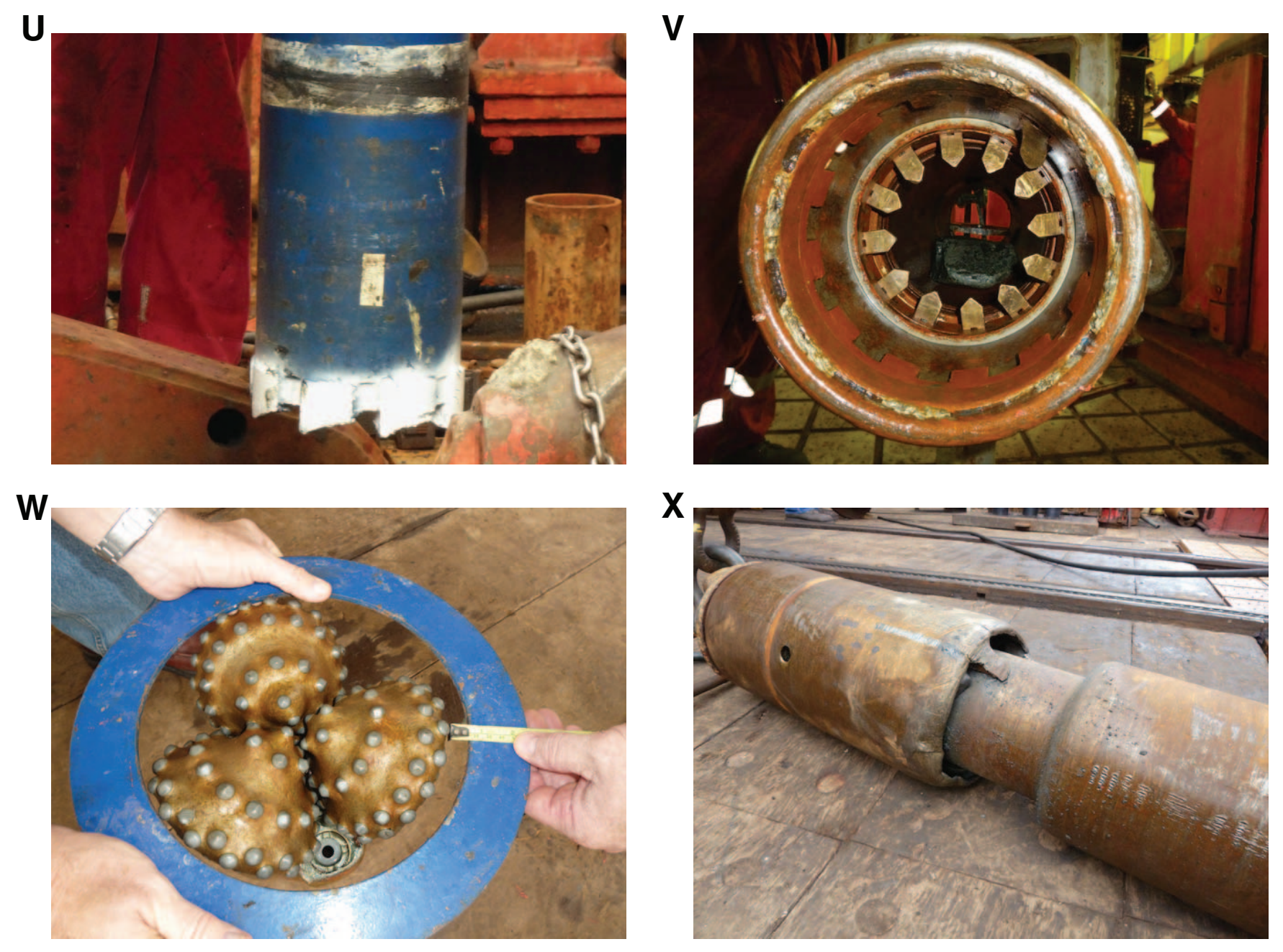
Figure F19 (continued). Y. Under gauge and worn Smith tricone bit used for Run 15 (W). Z, AA. 9 inch Smith FH3VPS tricone bit used for Run 16. This more armored bit (compare with the previous one in Y) was more efficient to ream and clean the undergauge bottom of the hole. It returned in gauge to the rig floor, and six large teeth were missing. BB. Heavily worn and undergauge 9 inch flat-bottomed milling tool used for Run 17. This tool worked at the bottom of the hole for $12 \mathrm{~h}$; its final (terminal) state indicates the very abrasive nature of metal debris and/or rocks at the bottom of the hole and an undergauge lowermost portion (tens of centimeters) of the hole. Note for comparison the hard-facing structure of the next milling tool (DD) on the right side of the picture. (Continued on next page.)
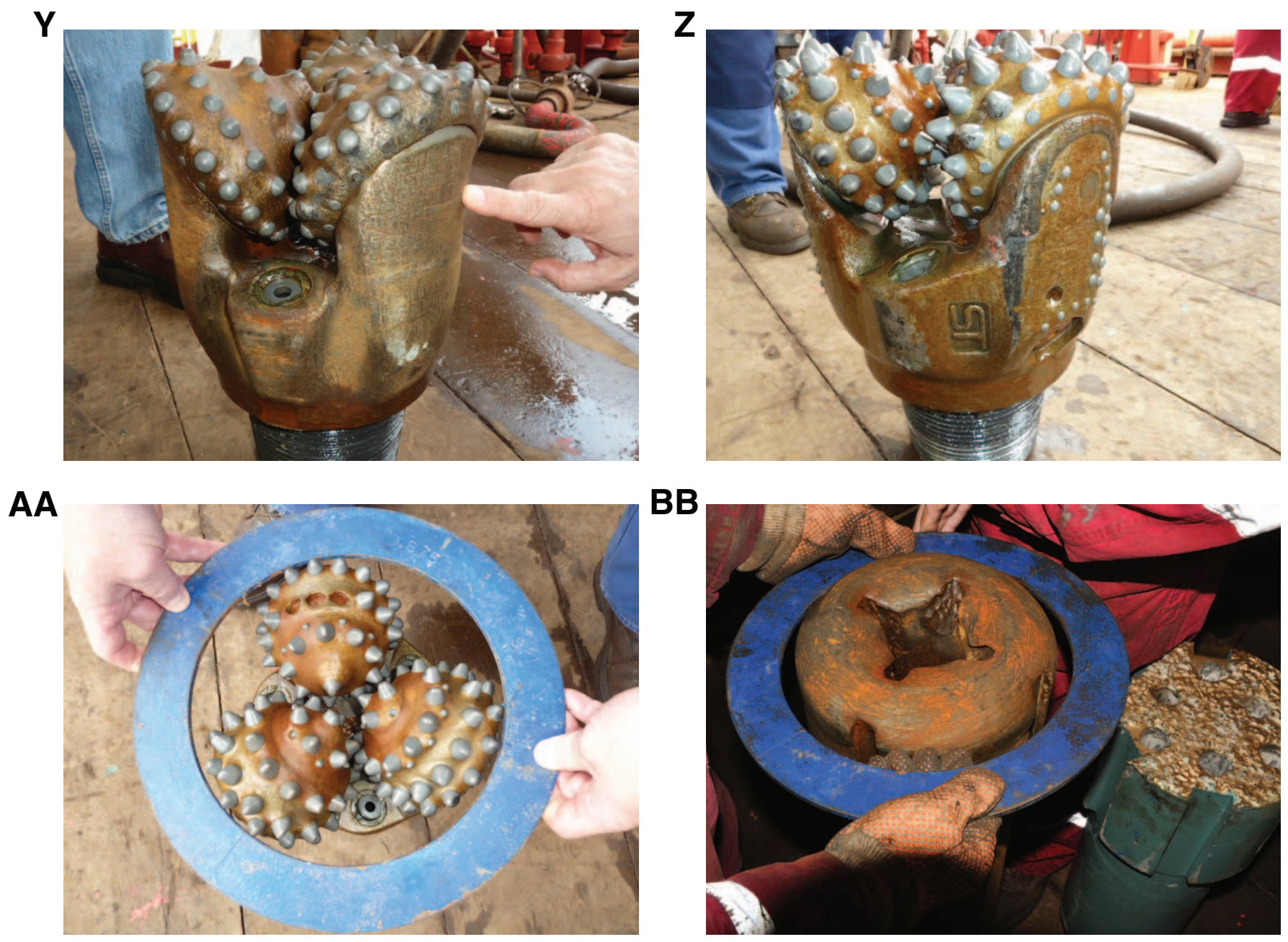
Figure F19 (continued). CC. Damaged bit sub junk basket (BSJB) used for Run 17, probably caused by granoblastic basalt angular blocks falling down the borehole walls while milling at the bottom. DD. 9 inch flat-bottomed milling tool used for Run 18. Note the hard-facing structure of the bottom of the tool. EE. The BSJB used for Run 18 returned with a damaged pocket, probably due to rock(s) detached from the borehole wall (CC). FF. 9 inch flat-bottomed milling tool used for Run 18, after working $6 \mathrm{~h}$ at the bottom of the hole. The abrasive surface (note the difference with DD) was eroded away and some external junk damage noted on the side of the tool and the crossover sub directly above the milling tool. (Continued on next page.)

\section{CC}

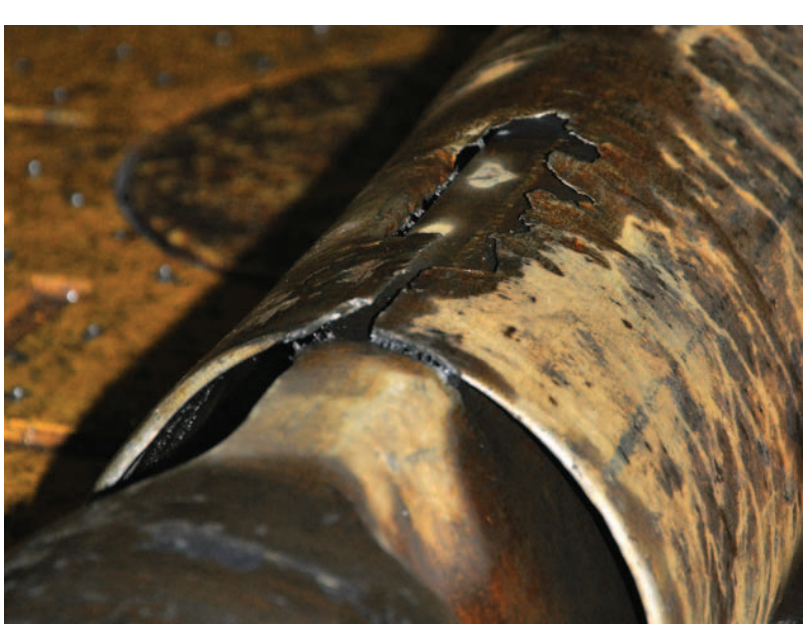

\section{EE}

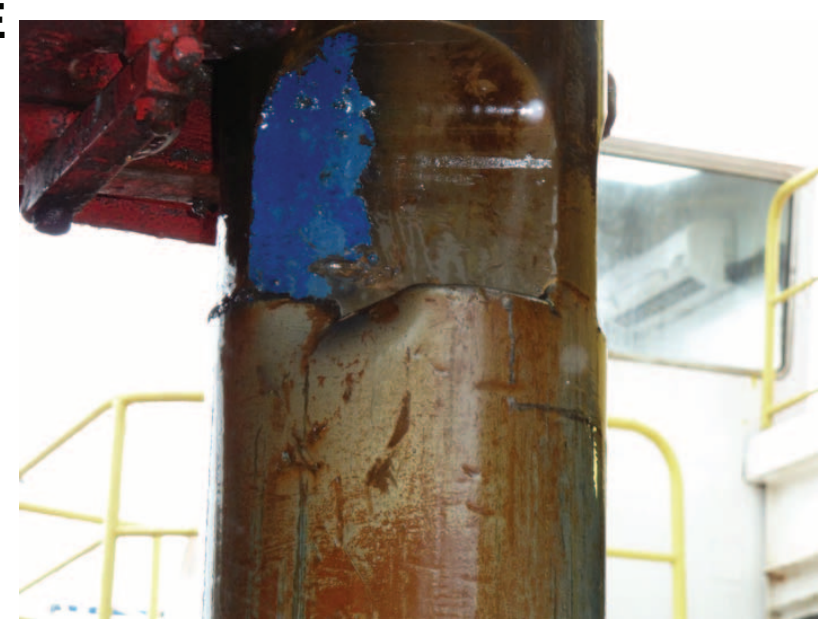

\section{DD}

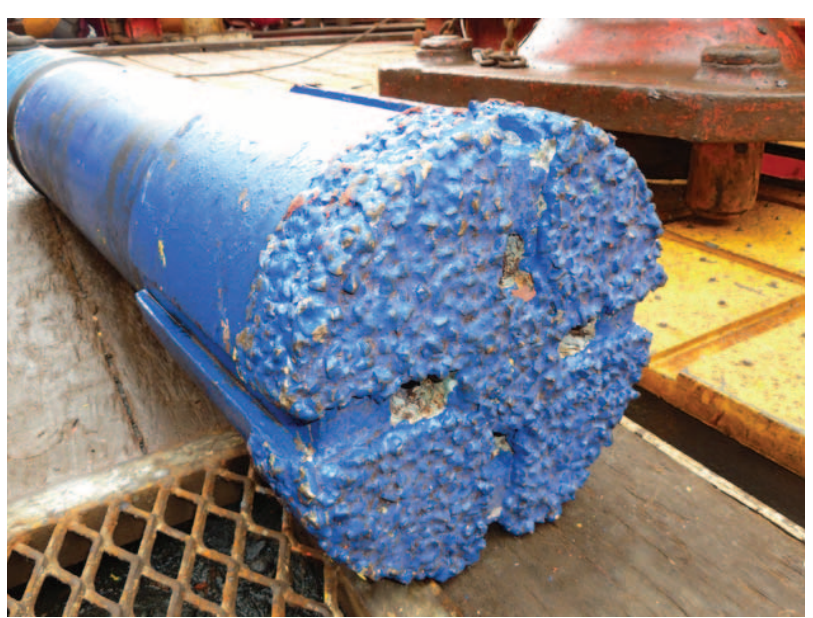

FF

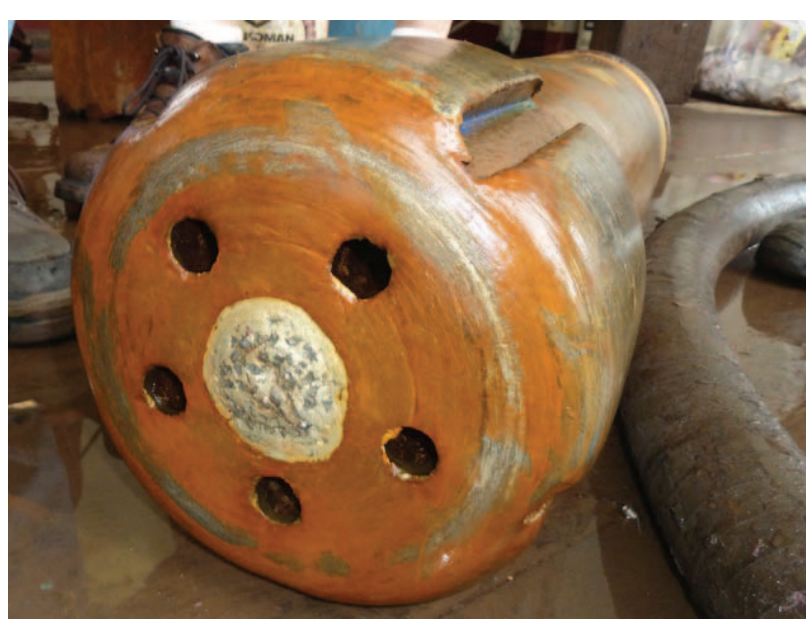


Figure F19 (continued). GG. Bottom of the Bowen RCJB used for Runs 19 through 21 . Note the spring fingers of the catching structure inside the tool. HH. The RCJB was deployed in Runs 19 through 21 with two EXJBs and one BSJB. This picture shows the junk basket tower being assembled on the rig floor. II. The RCJB on its return to the rig floor after Run 19 recovered four large cobbles of granoblastic basalt and rock pebbles. JJ. Jets on the outside of the RCJB, just above the tool bit. These grooves in the metallic body of the tool were formed by high-pressure water flow when reverse circulation was activated at the bottom of the hole (compare with the new tool in N). The picture was taken at the end of Run 20 (i.e., after a total of four runs for this tool). (Continued on next page.)
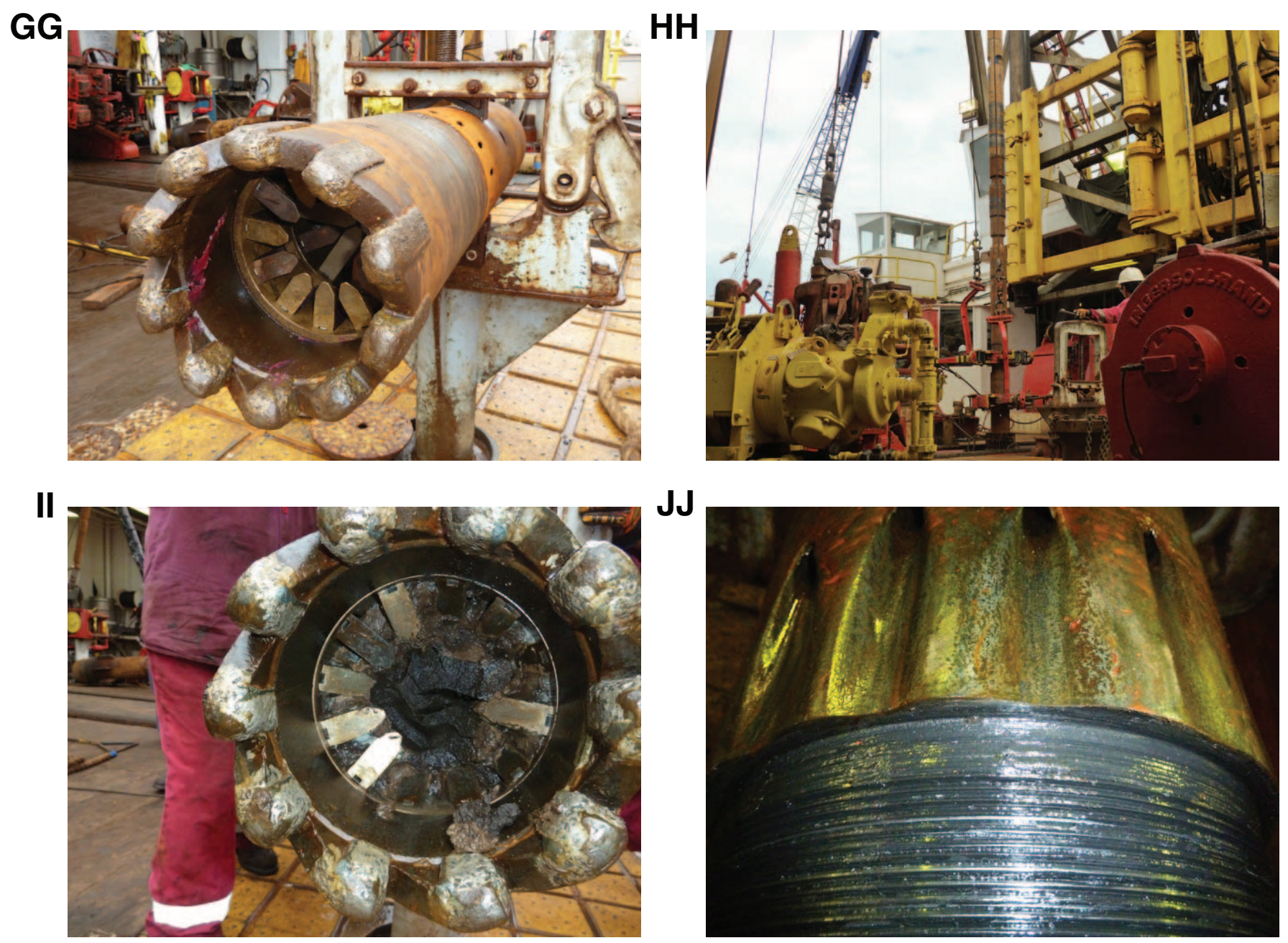
Figure F19 (continued). KK. Bowen fishing magnet tool, at the end of Run 22, with very little metal debris, although the tool tagged the bottom of the hole. LL. Damaged bowsprings of the upper centralizer of the logging tools after running the first (triple combo) logging run (Run 23). MM. The bowsprings were replaced by new, slightly thicker ones, which caused the Formation MicroScanner-sonic tool to be stuck in the logging $\mathrm{BHA}$ at the start of the second logging run. This picture shows the bowsprings stuck in the landing saver sub during the recovery of the tool. NN. Ulterra RCB C-9 bit used for the last run of Expedition 335 (Run 24), for coring and then cementing the lowermost $10 \mathrm{~m}$ of the hole and the interval between 910 and 940 mbsf. (Continued on next page.)

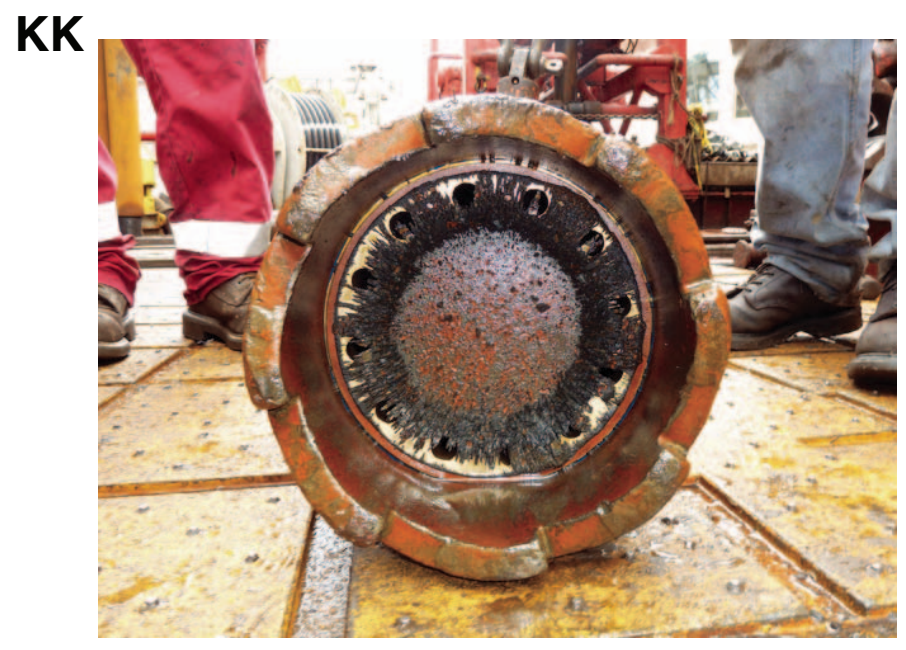

\section{LL}

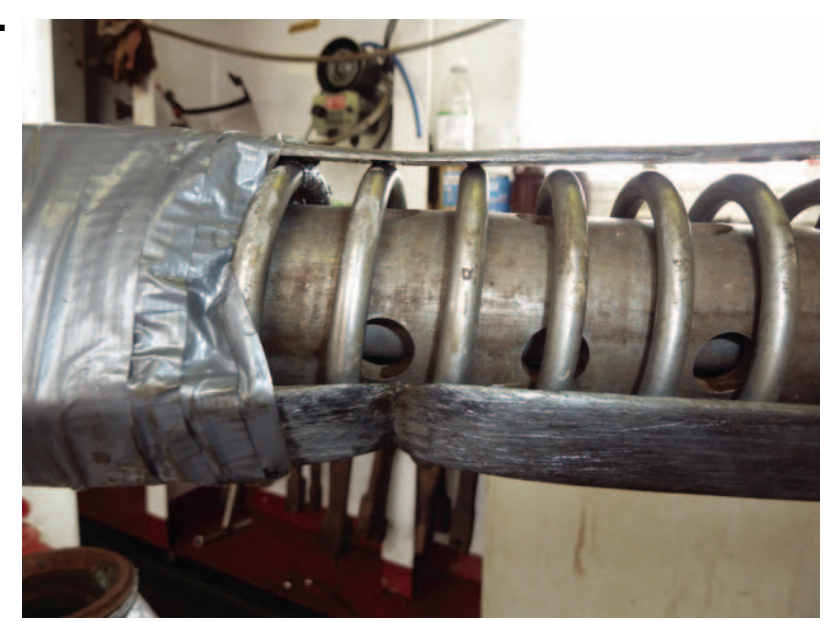

\section{MM}

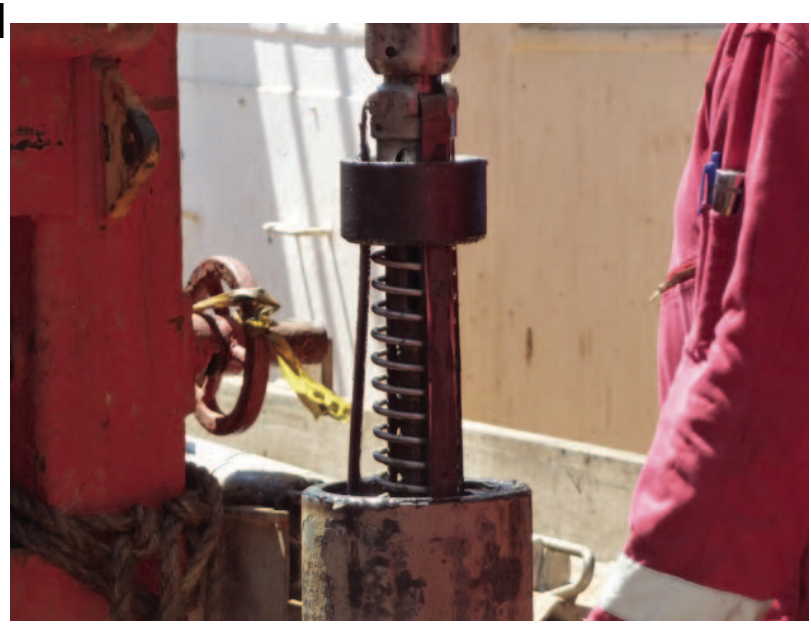

NN

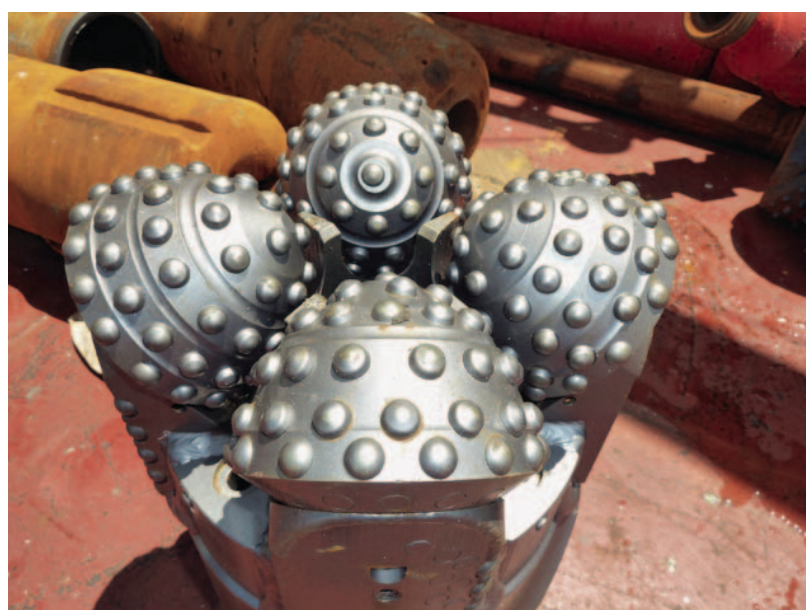


Figure F19 (continued). OO. The C9 bit used for Run $24(\mathrm{NN})$ returned to the rig floor in relatively good condition and nearly in gauge. It cored for $\sim 2.5 \mathrm{~h}$. PP. Worn outward faces of the cones, one missing tooth, and a small crack that started to propagate in the welding of the cone leg (see bottom right, close to the jet). QQ. Small marks on the outward facing structure of the Run 24 C9 bit, likely caused by hard, abrasive granoblastic basalt. Note the difference with the next picture. RR. For comparison with QQ, this picture shows the partly broken bit from Expedition 312 (missing cones), heavily damaged and cut by metal junk.
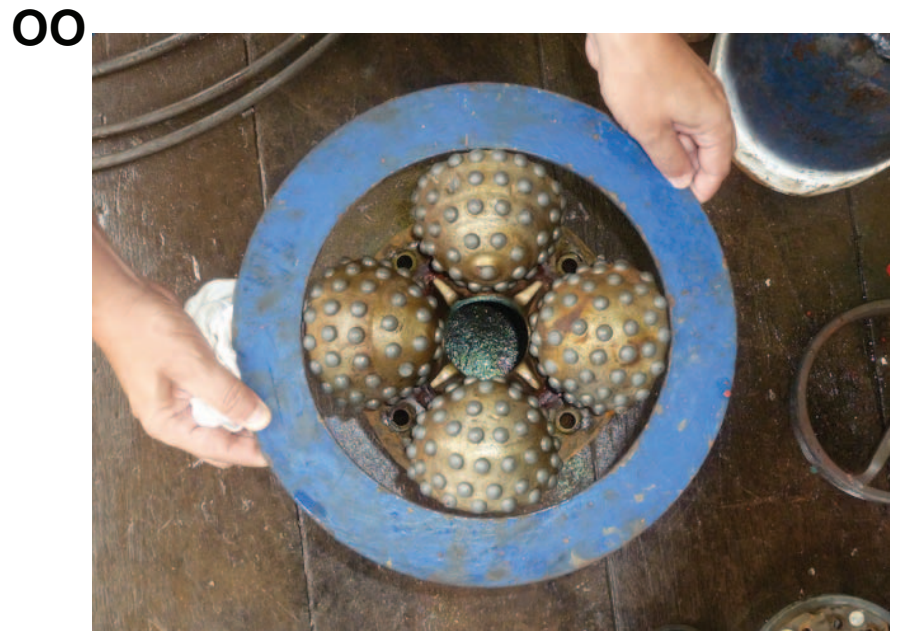

QQ

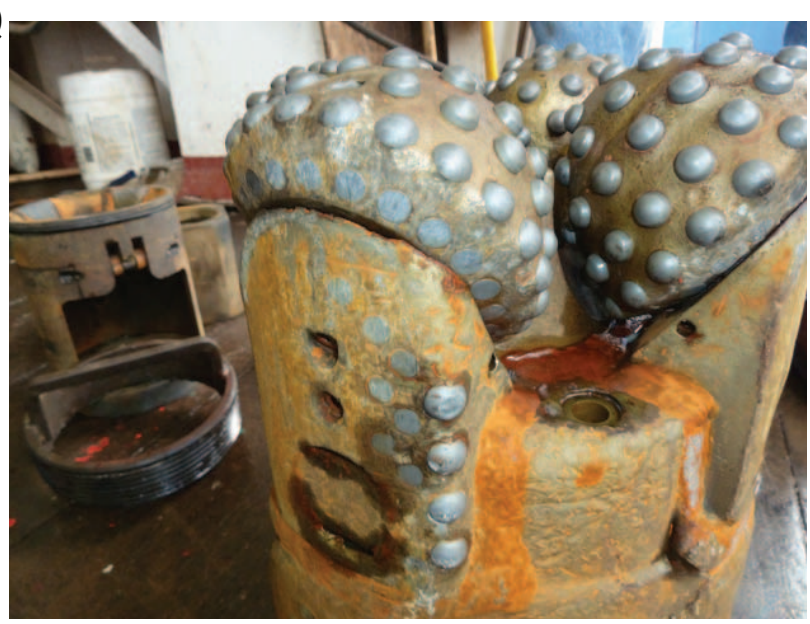

\section{PP}

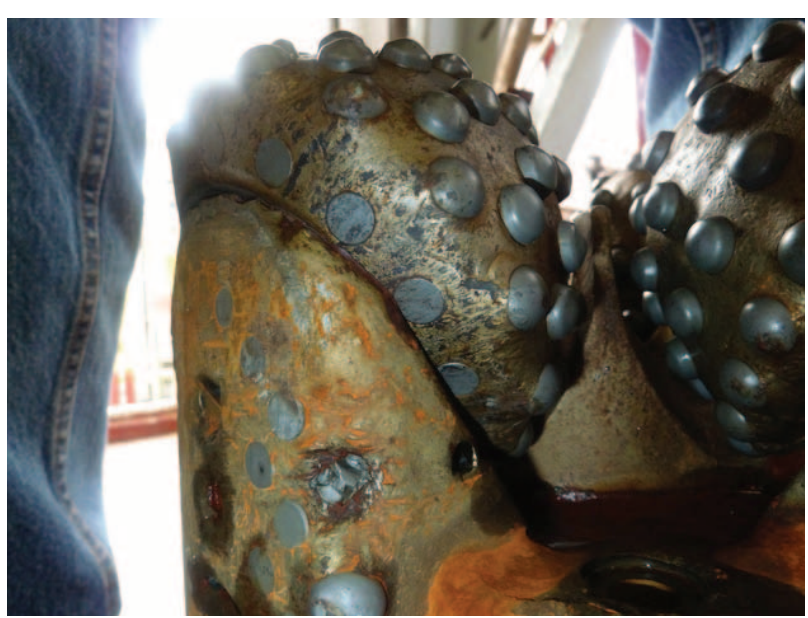

RR

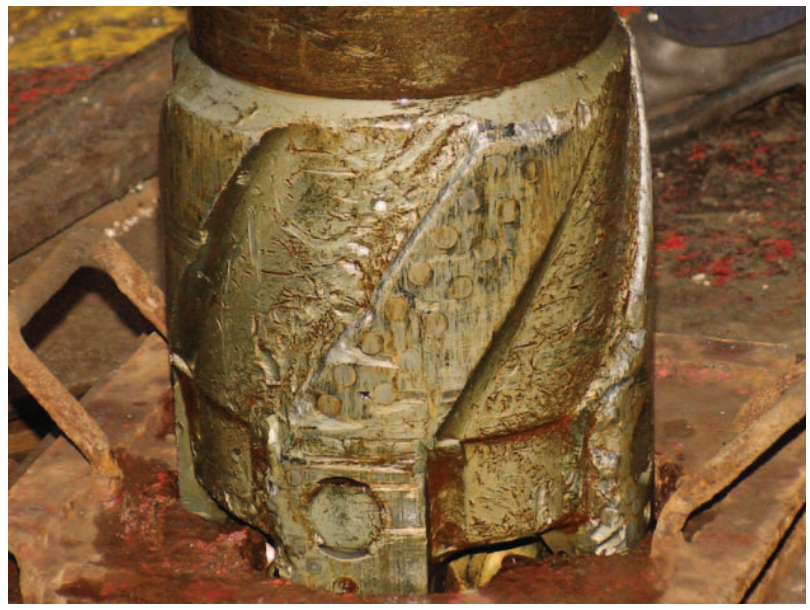


Figure F20. Simplified stratigraphic column of Hole 1256D at the end of Expedition 312 showing the caliper, $P$-wave velocity, and resistivity logs. Note the large out-of-gauge interval from 920 to $930 \mathrm{mbsf}$.

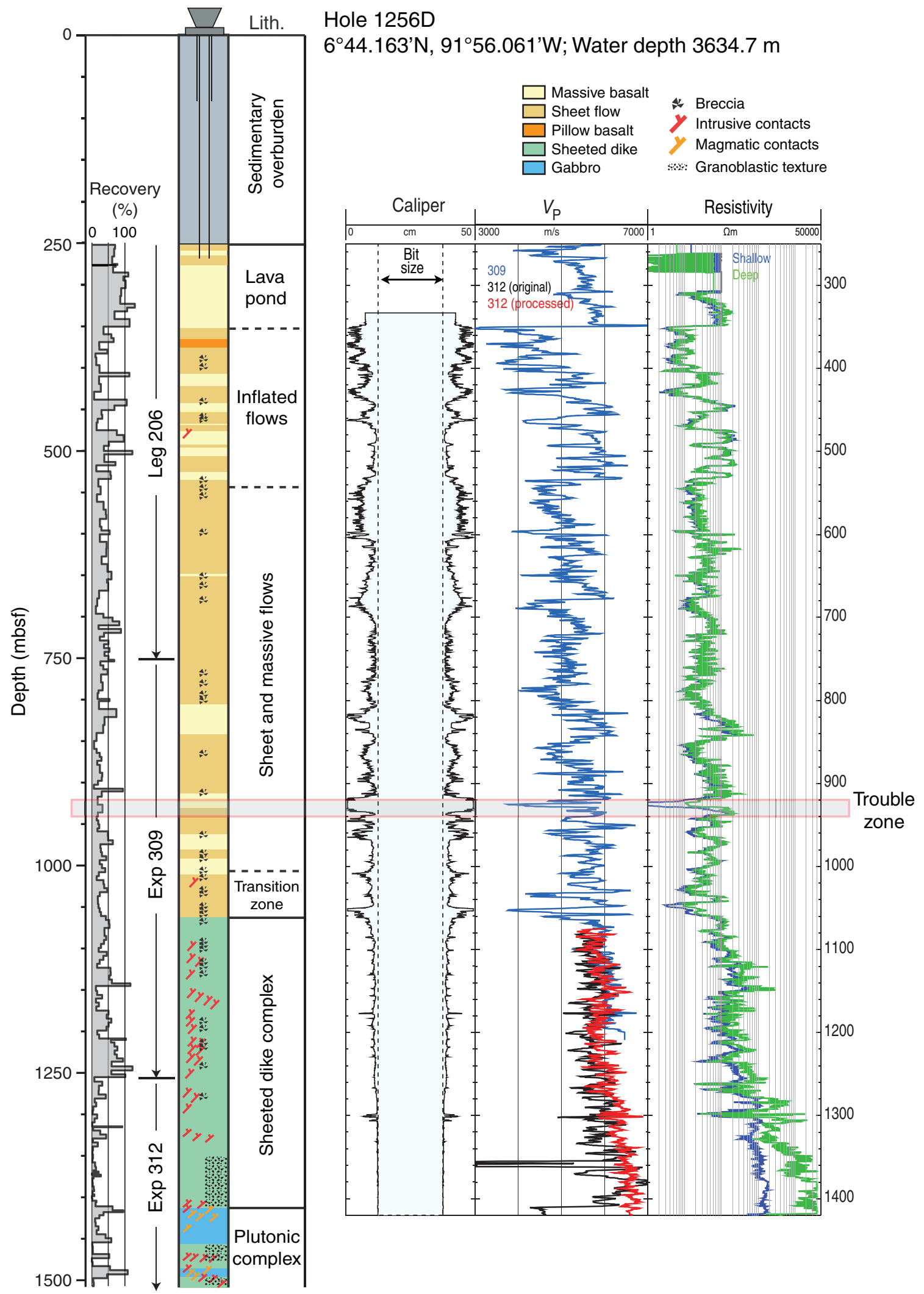


Figure F21. Perspective diagram of Hole 1256D showing the deviation of the hole against a background of the simplified crustal stratigraphy to $\sim 1400$ mbsf. The hole trajectory color and diameter is proportional to the caliper. Hole 1256D deviates with a near pure westerly trend with the hole at the granoblastic dike/Gabbro 1 boundary $60 \mathrm{~m}$ to the west of the reentry cone (directly below the ship's bell when on a westerly heading).

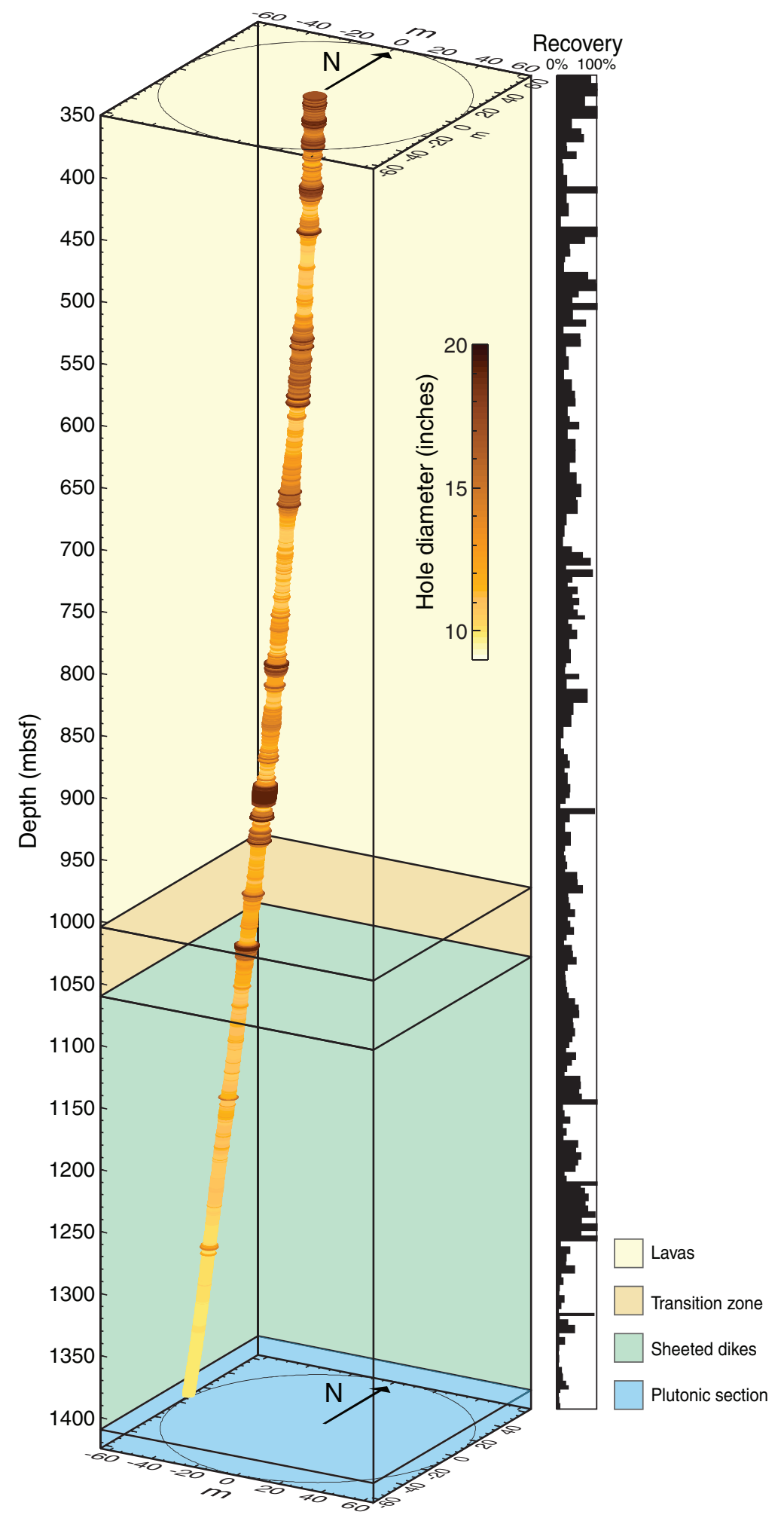


Figure F22. Caliper logs between 900 and 1000 mbsf recorded by the Ultrasonic Borehole Imager (UBI), Formation MicroScanner (FMS), and Hostile Environment Litho-Density Sonde (HLDS) tools during Expedition 309 and by the HLDS tool during Expeditions 309/312 and 335. Comparison of the Expedition 335 and 312 caliper logs shows that cementing has improved the interval from 930 to 970 but widely out-of-gauge hole persists above that.

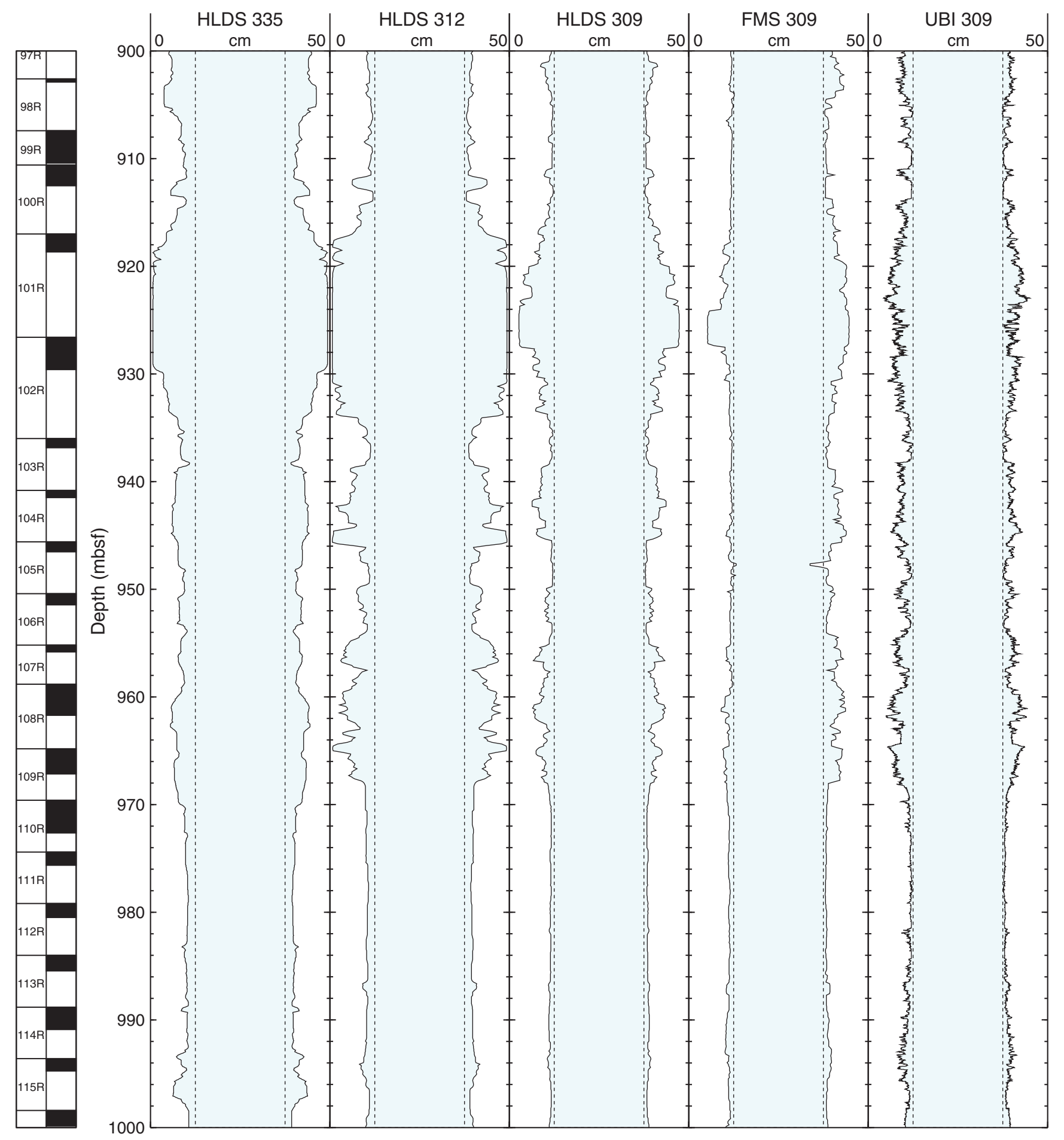


Figure F23. Geological and wireline observations of the problematic zone between 910 and 970 mbsf in Hole $1256 \mathrm{D}$. A. Penetration rate and recovery, along with core and unit numbers. B. Caliper log from the end of Expedition 312. The zone from 920 to $930 \mathrm{mbsf}$ is strongly out of gauge (>20 inches; i.e., larger than the diameter of the caliper tool, as indicated by the dashed curves). There is no clear relationship between the trouble zone, lava flow type, core recovery, or penetration rate. C. Caliper log from the end of Expedition 335. The intervals cemented during Expedition 335 are indicated on the right side. Comparison of Expedition 335 and 312 caliper logs shows that cementing has improved the interval from 930 to 970 but widely out-of-gauge hole persists above that. D. Wireline temperature measurements show a strong negative inflection at $~ 920-940$ mbsf, indicating the return of cold drilling fluids from the formation following the cessation of drilling operations. $\mathrm{EDTCB}=$ enhanced digital telemetry cartridge, $\mathrm{MTT}=$ Modular Temperature Tool, $\mathrm{TAP}=$ Temperature/Acceleration/Pressure tool. (Figure shown on next page.) 
Figure F23 (continued). (Caption shown on previous page.)
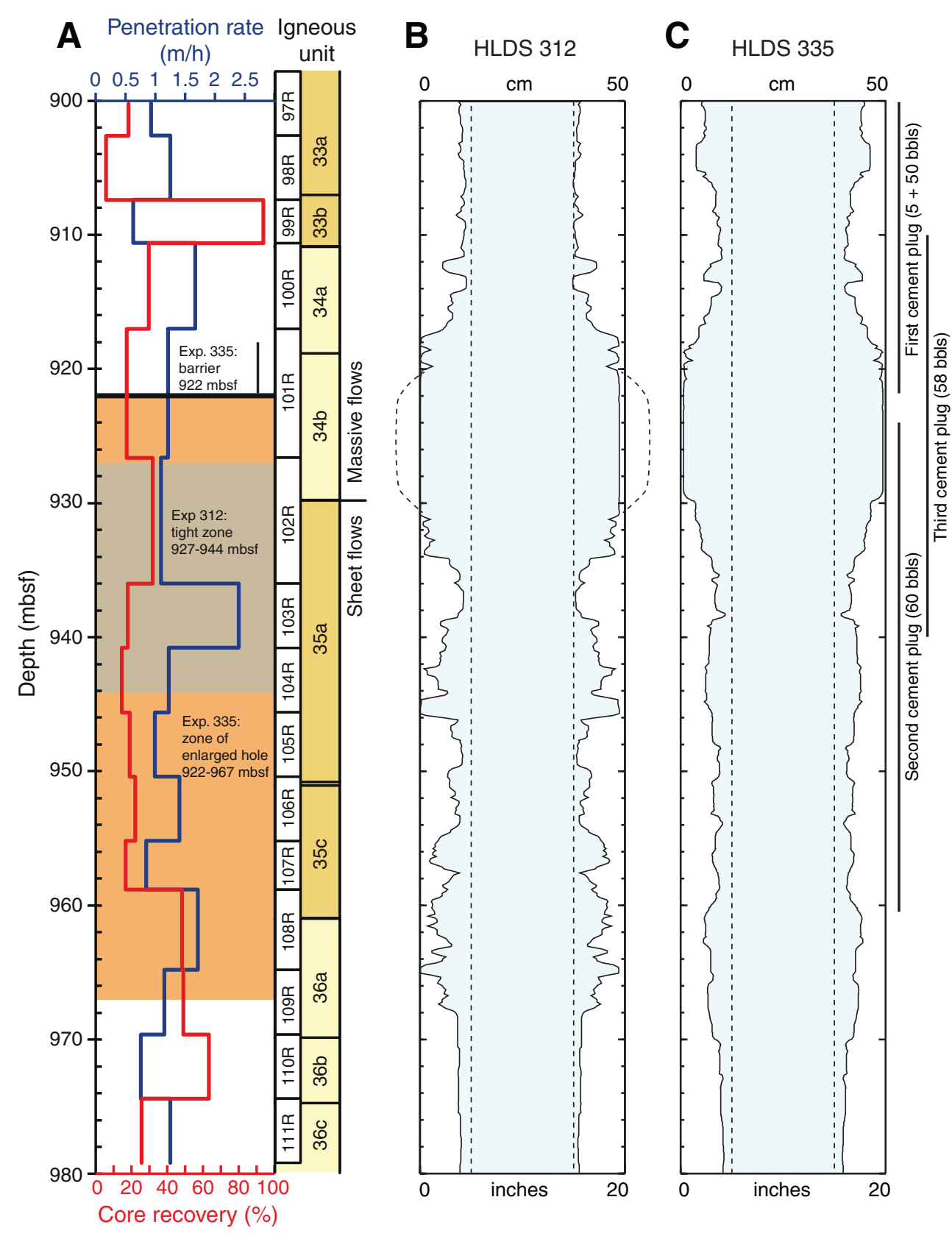

D

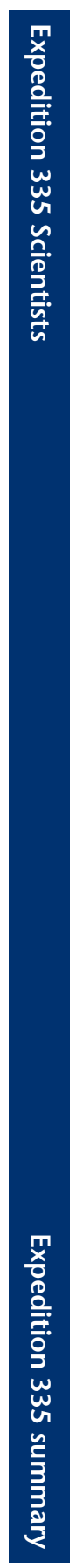


Figure F24. Sketch of a possible cause for the obstruction at 922 mbsf (not to scale; the deviation of the BHA is strongly exaggerated). Yellow slabs represent more massive units in fractured flows.

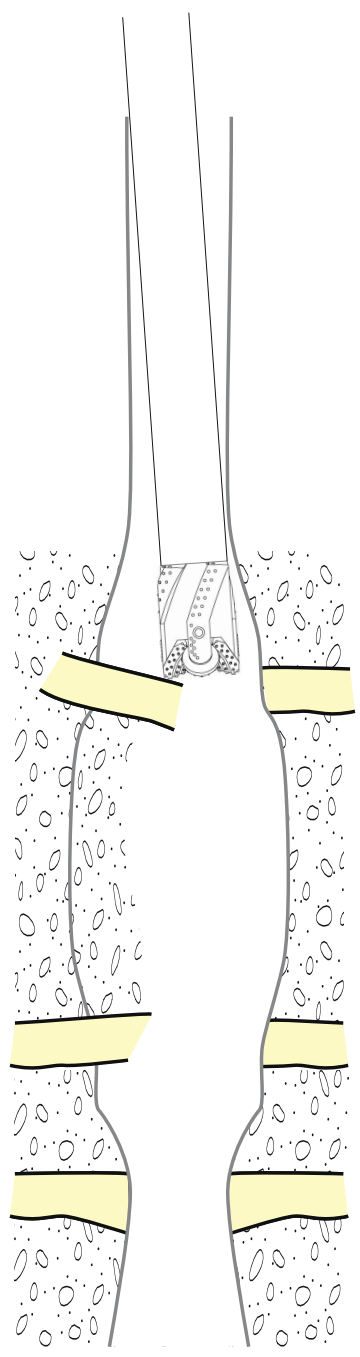


Figure F25. Plot showing the progressive deepening of Hole 1256D over four scientific ocean drilling cruises and the division of time on site into casing, coring, downhole logging, and hole remediation activities.

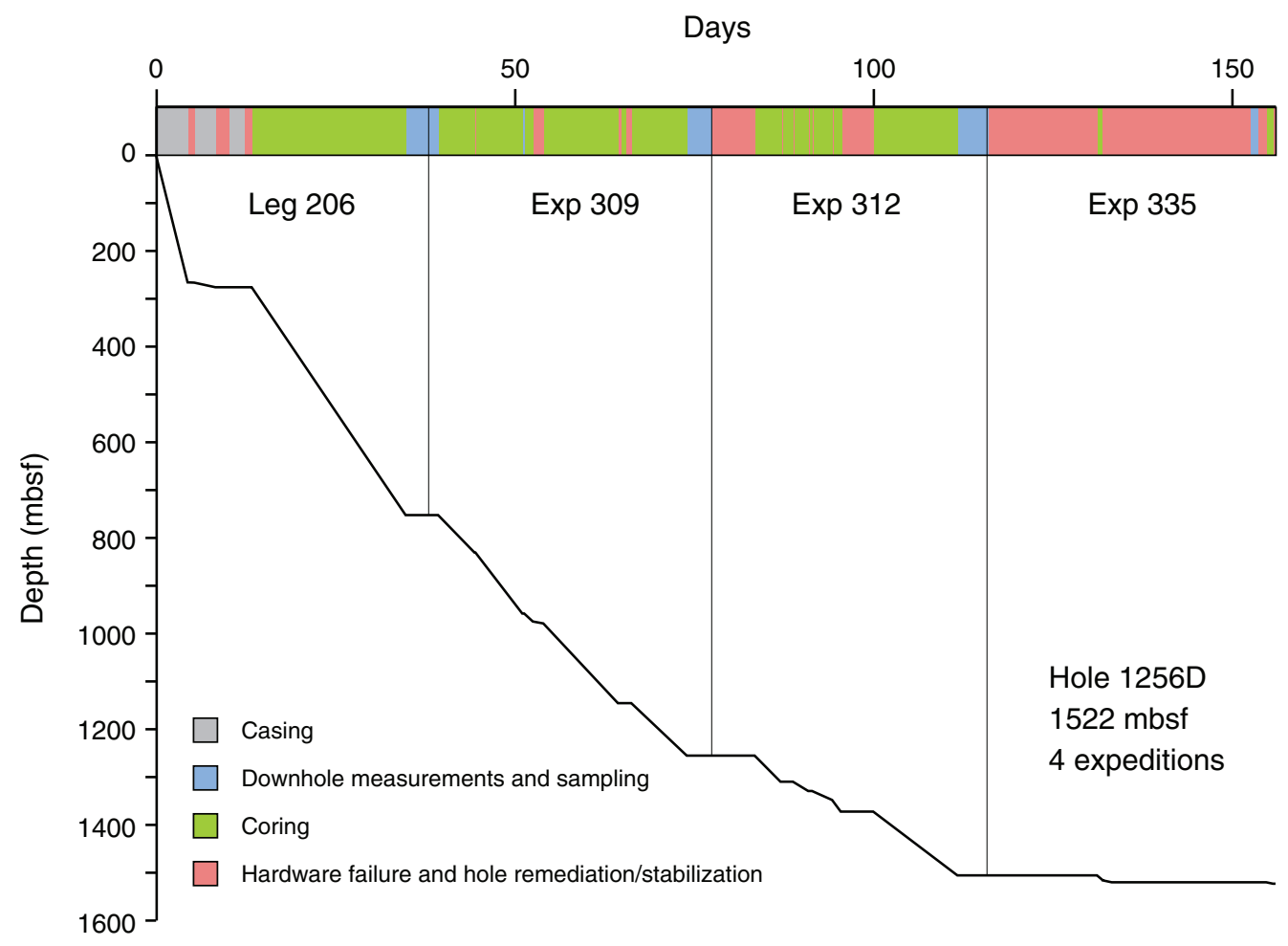


Figure 26. Stratigraphic column for Hole 1256D at the end of Expedition 335, showing the major and minor lithologic divisions of the upper oceanic crust.

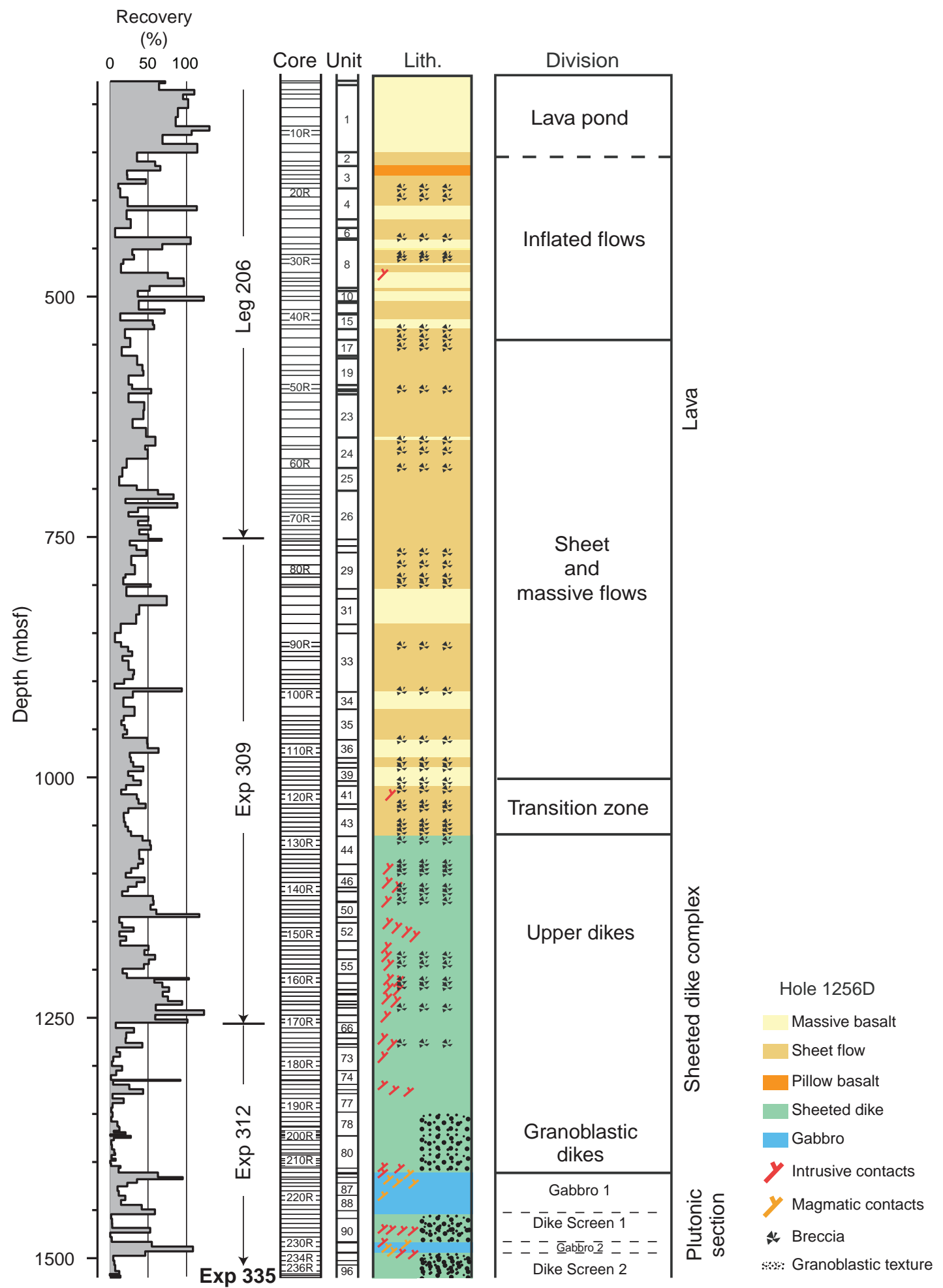


Figure F27. Photomicrograph in plain polarized light of almost completely recrystallized basalt (granoblastic texture), showing a relict plagioclase microphenocryst and an orthopyroxene vein (Sample 335-1256D-236R1, Piece 7 [Thin Section 5]). Opx = orthopyroxene.

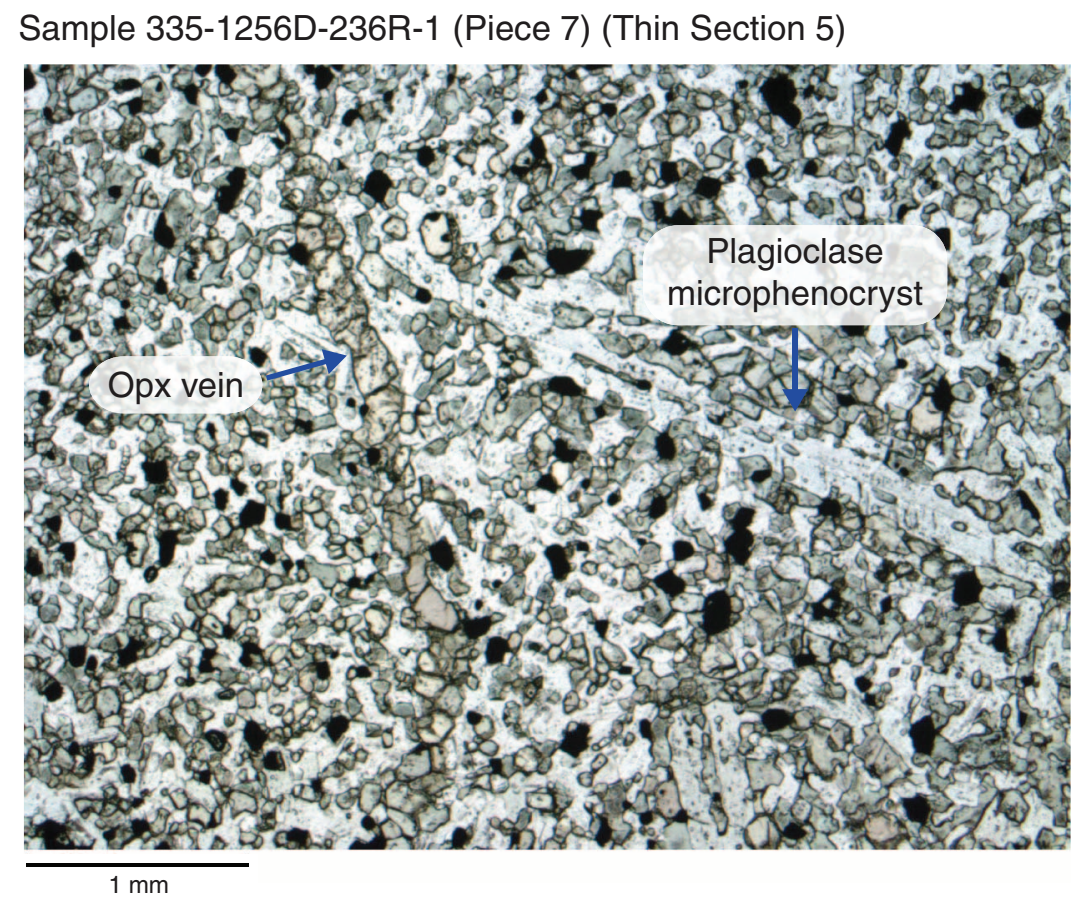


Figure F28. Overview of the lithostratigaphy of the upper crust-lower crust transition recovered in Hole 1256D.

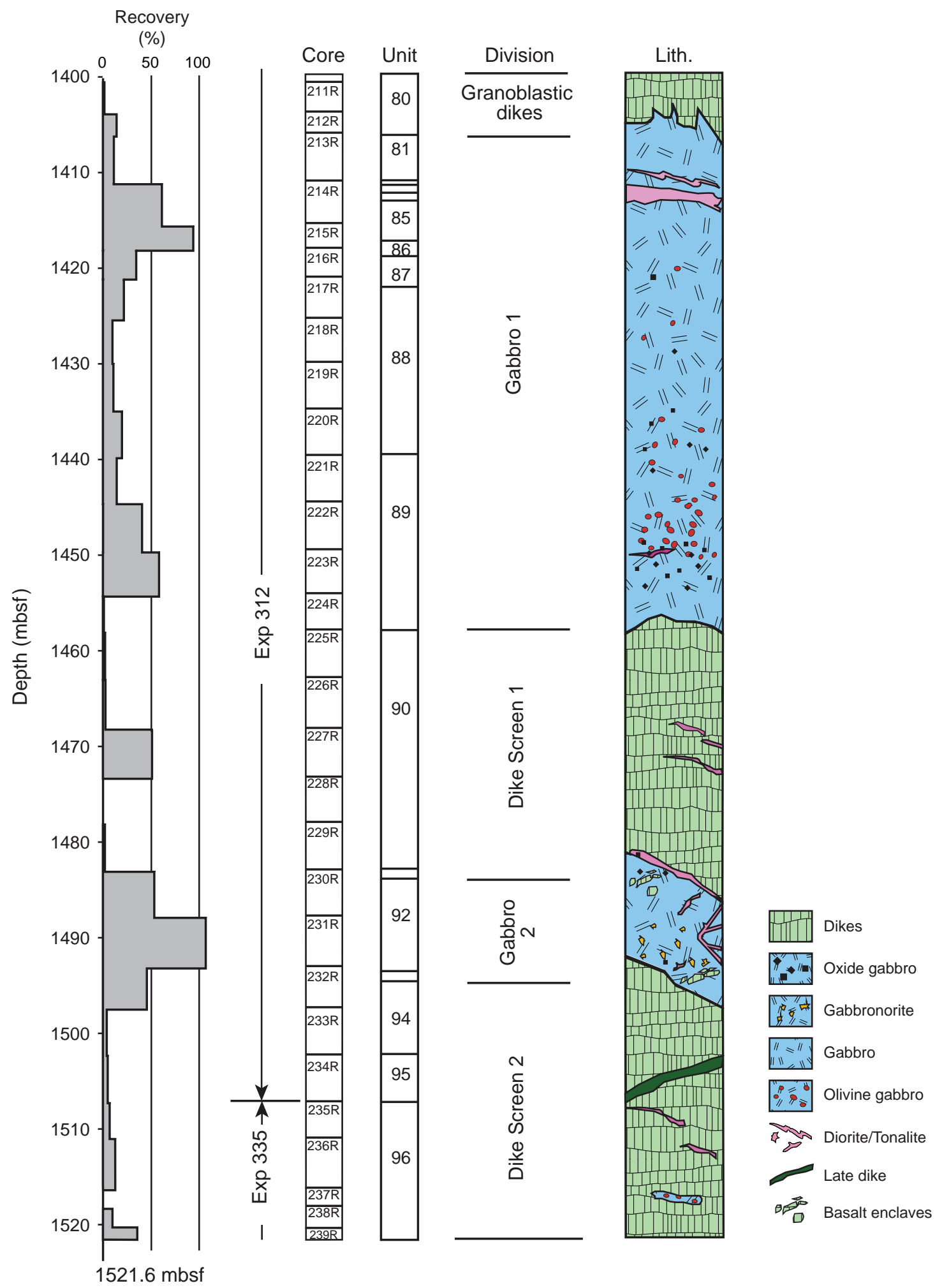


Figure F29. A. Close-up photograph illustrating the occurrence of a diorite dikelet crosscutting granoblastic basalt (Sample 335-1256D-Run19-RCJB-Rock C). B. Overview of a diorite patch in a fine-grained granoblastic aphyric basalt (cross-polarized light) (Sample 335-1256D-Run11-EXJB [Thin Section 13]). An offshoot of the diorite crosscuts the granoblastic basalt, demonstrating that the diorite is intrusive. (Continued on next page.)

A

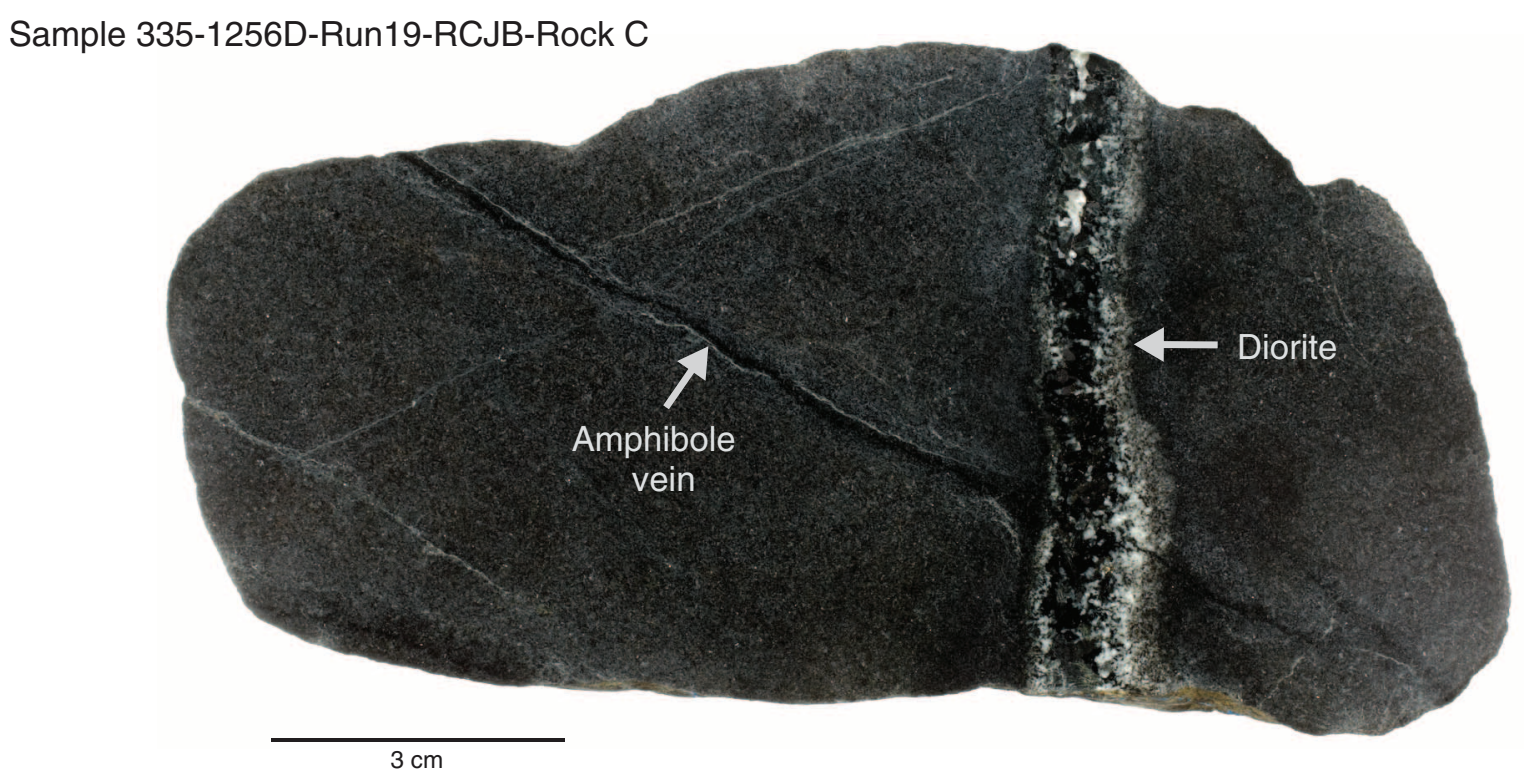

B Sample 335-1256D-Run11-EXJB (Thin Section 13)

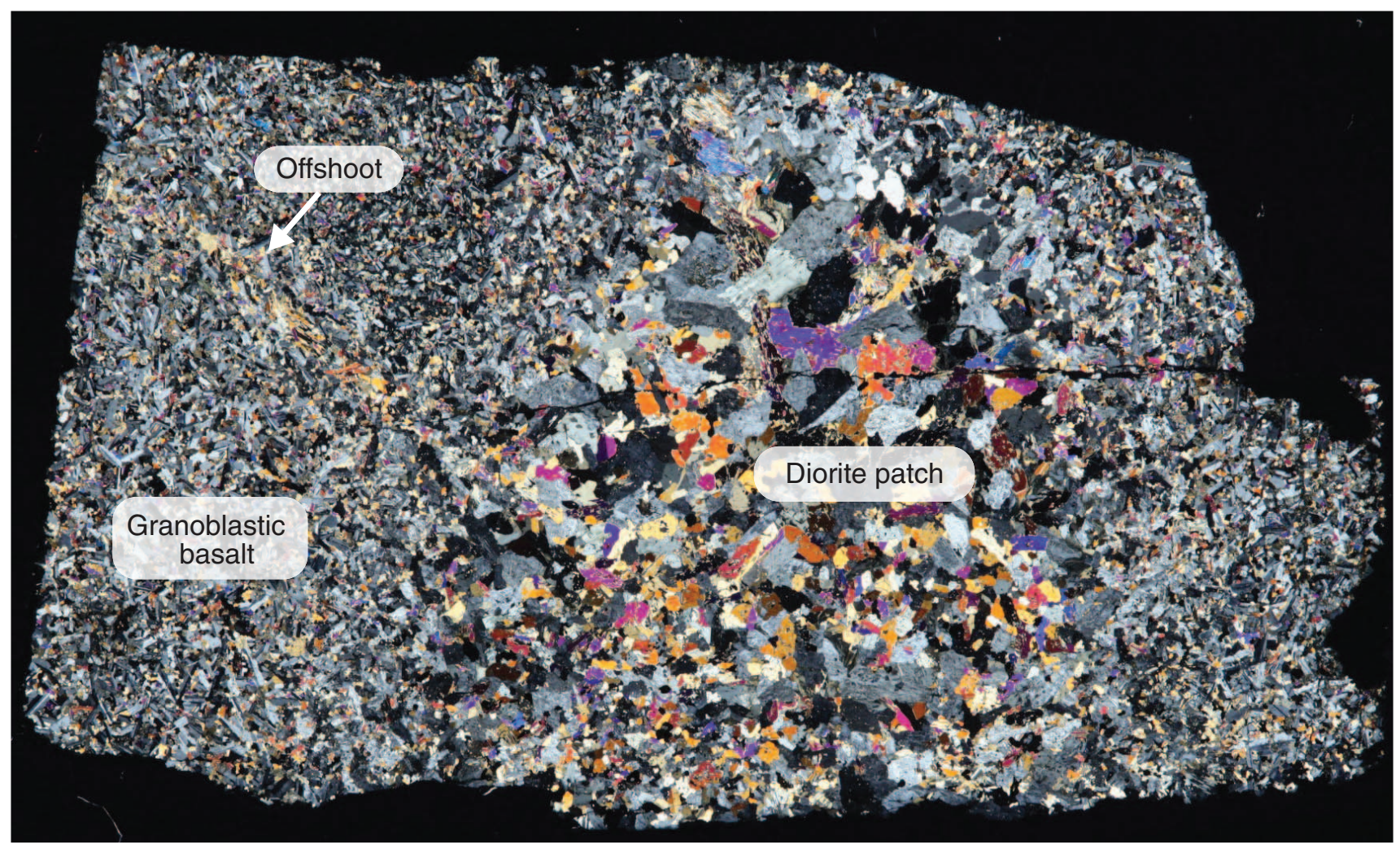

$0.5 \mathrm{~cm}$ 
Figure F29 (continued). C. Close-up photograph of orthopyroxene-bearing olivine gabbro (Sample 3351256D-Run20-RCJB-Rock C).

C Sample 335-1256D-Run 20-RCJB-Rock C

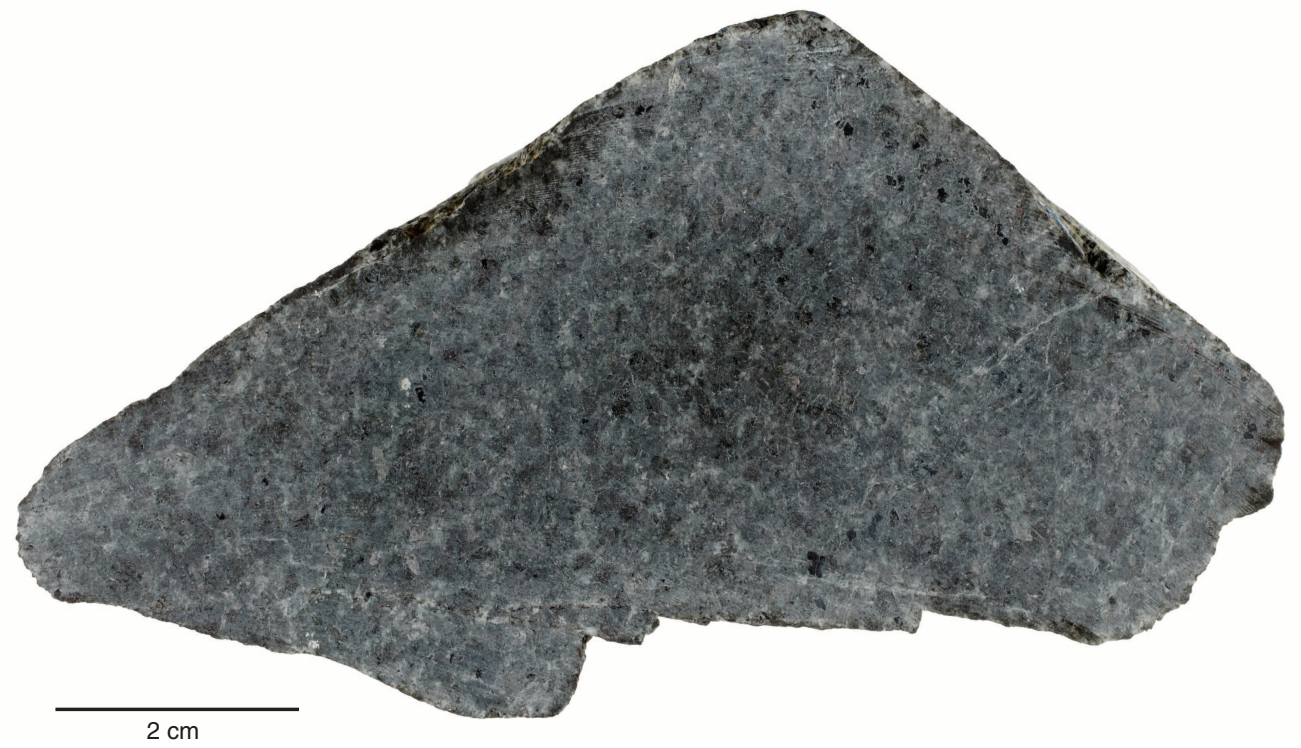


Figure F30. Sketch of a hypothetical outcrop in a future Site 1256 ophiolite of the dike-gabbro transition zone showing the contact relationships observed in the cores and junk basket rocks recovered during Expedition 335. A. Diorite dikelet, comprised predominantly of primary igneous amphibole and plagioclase, crosscutting granoblastic basalt (Sample 335-1256D-Run19-RCJB-Rock C). B. Fine-grained dike chilled against coarser grained dike (Sample 335-1256D-Run12-RCJB-Rock S). The entire sample is recrystallized to granoblastic assemblages of plagioclase, orthopyroxene, clinopyroxene, magnetite, and ilmenite. Later fine post-contact metamorphic hydrothermal amphibole veins (not shown) cut across the contact and both dikes. C. Chilled and brecciated dike margin recrystallized to granoblastic assemblages (Sample 335-1256D-Run14-EXJB-Foliated). Angular clasts consist of granoblastic plagioclase with minor orthopyroxene, clinopyroxene, ilmenite, and magnetite and are recrystallized from chilled dike margin breccia protolith. Clast matrix is orthopyroxene rich with minor clinopyroxene, plagioclase, and oxides and is recrystallized from hydrothermal minerals (amphibole and chlorite) that veined and cemented the breccia protolith. D. Subophitic texture in gabbro (Sample 335-1256D-Run11-EXJB [Thin Section 12]). E. Diorite vein crosscutting a conjugate set of metamorphic orthopyroxene veins (Sample 335-1256D-Run19-RCJB-Rock B). F. Post-contact-metamorphic hydrothermal hornblende vein cutting granoblastic basalt (Sample 335-1256D-238R-1, 2-4 cm [Piece 1]). G. Granoblastic basalt with a diorite patch (Sample 335-1256D-Run11-EXJB-Rock [Thin Section 13]). H. Granoblastic orthopyroxene vein, recrystallized from precursor hydrothermal vein, in granoblastic dike (Sample 335-1256D-238R-1, 2-4 cm [Piece 1]). Orthopyroxene vein is cut by small post-contact-metamorphic hydrothermal amphibole vein. I. Post-contact-metamorphic hydrothermal amphibole vein cutting granoblastic basalt, with $1 \mathrm{~mm}$ wide amphibole-rich alteration halo where pyroxenes are replaced by amphibole (Sample 335-1256D-Run12-RCJB-Rock B). (Figure shown on next page.) 


Figure F31. Depth profiles for the lower part of Hole 1256D for Mg\#, Zr, Zr/Y (mass ratio), Zn, and Cu. Rock samples retrieved from junk basket (JB) runs to the bottom of the hole $(\mathrm{BOH})$ are plotted in the bottom boxes. $\mathrm{C}=$ cored.
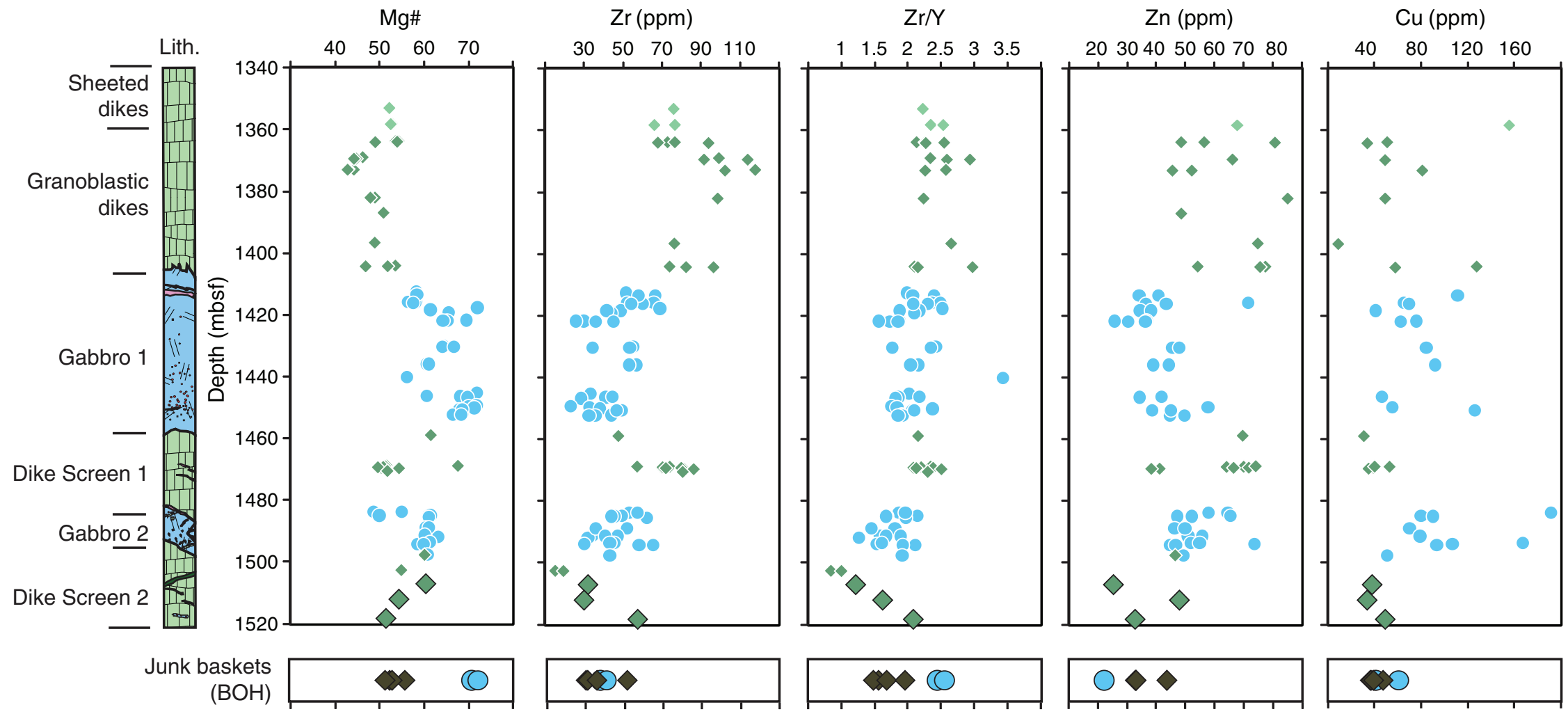

$$
\begin{array}{ll}
\text { Expedition } 335 & \text { Hole 1256D } \\
\diamond \text { Granoblastic dikes C } & \text { Sheeted dikes } \\
\diamond \text { Granoblastic dikes JB } & \diamond \text { Granoblastic dikes } \\
\bigcirc \text { Gabbro JB } & \text { Gabbros }
\end{array}
$$


Figure F32. Photographs summarizing sequence of major alteration and metamorphic features in Expedition 335 cores and rocks. Intrusive dike contact in A represents original crustal construction processes. The darker gray, very fine grained dike at left in A is chilled against the lighter gray fine-grained dike at right (red line highlights contact). The lower sheeted dike complex was hydrothermally altered and subsequently intruded by gabbros and more evolved rocks, as exemplified in C, where diorite intrudes into a fine-grained dike (red dashed line). The host sheeted dikes were contact metamorphosed to granoblastic assemblages at this stage, as illustrated by the recrystallized dike contact in B. Former hydrothermal veins were recrystallized into granoblastic veins as in E, where a light gray vein of granoblastic plagioclase + orthopyroxene cuts diagonally across the sample. Two granoblastic orthopyroxene veins are also shown in B (subvertical at center and right). Following crystallization of the intrusive rocks and cooling, hydrothermal fluids penetrated and altered the rocks, cutting across all earlier features (intrusive igneous contacts and contact metamorphic effects in A-E). Red boxes in A, C, and E are localizations of the close-ups shown in B, D, and F, respectively. A, B. Fine amphibole veins (arrows) that cut across igneous/dike contact (Sample 335-1256D-Run12-RCJB-Rock S [Thin Section 26]). C. Fine amphibole veins (arrows) and thicker amphibole vein with amphibole-rich alteration halo (Sample 3351256D-Run12-RCJB-Rock B [Thin Section 21]). D. Close-up (from C) of amphibole replacing pyroxenes along vein. E, F. Evolving hydrothermal activity, with dark greenish actinolite vein cutting across earlier light brown amphibole vein (Sample 335-1256D-238R-1, Piece 1 [Thin Section 6]). (Figure shown on next page.) 
Figure F32 (continued). (Caption shown on previous page.)

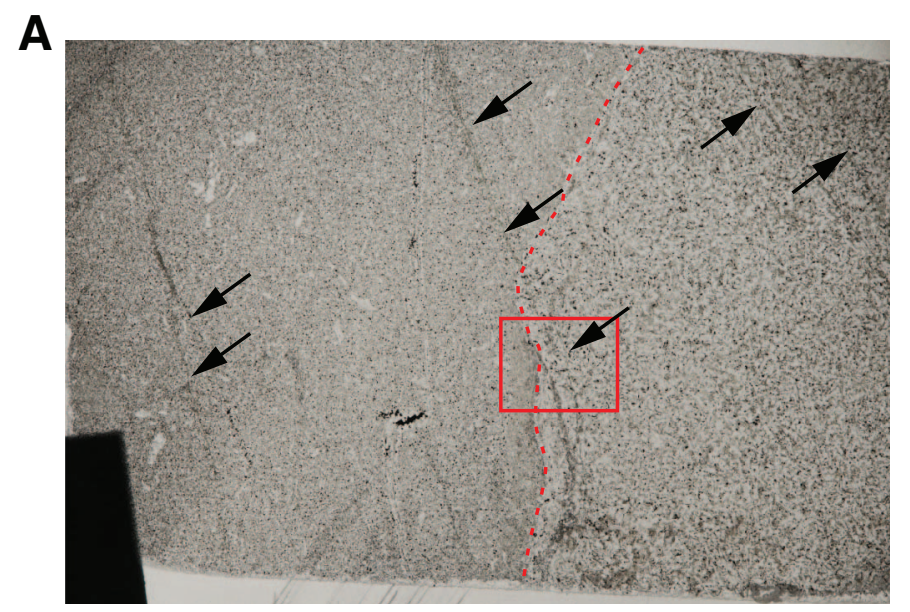

B

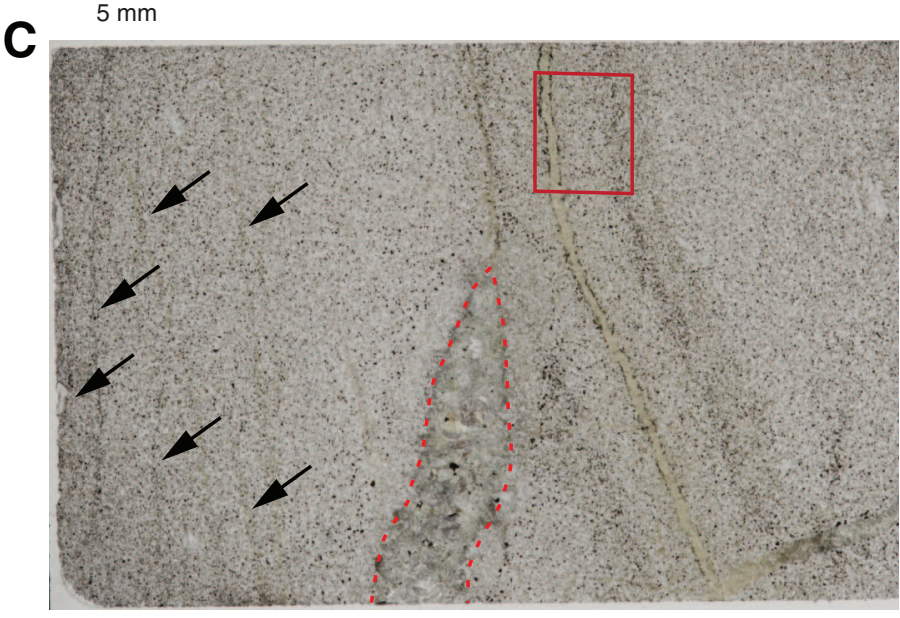

E

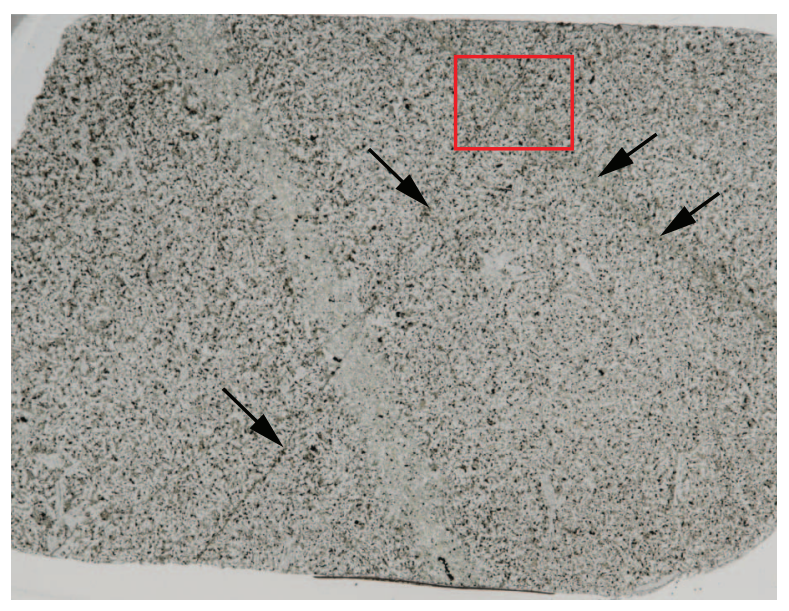

$5 \mathrm{~mm}$
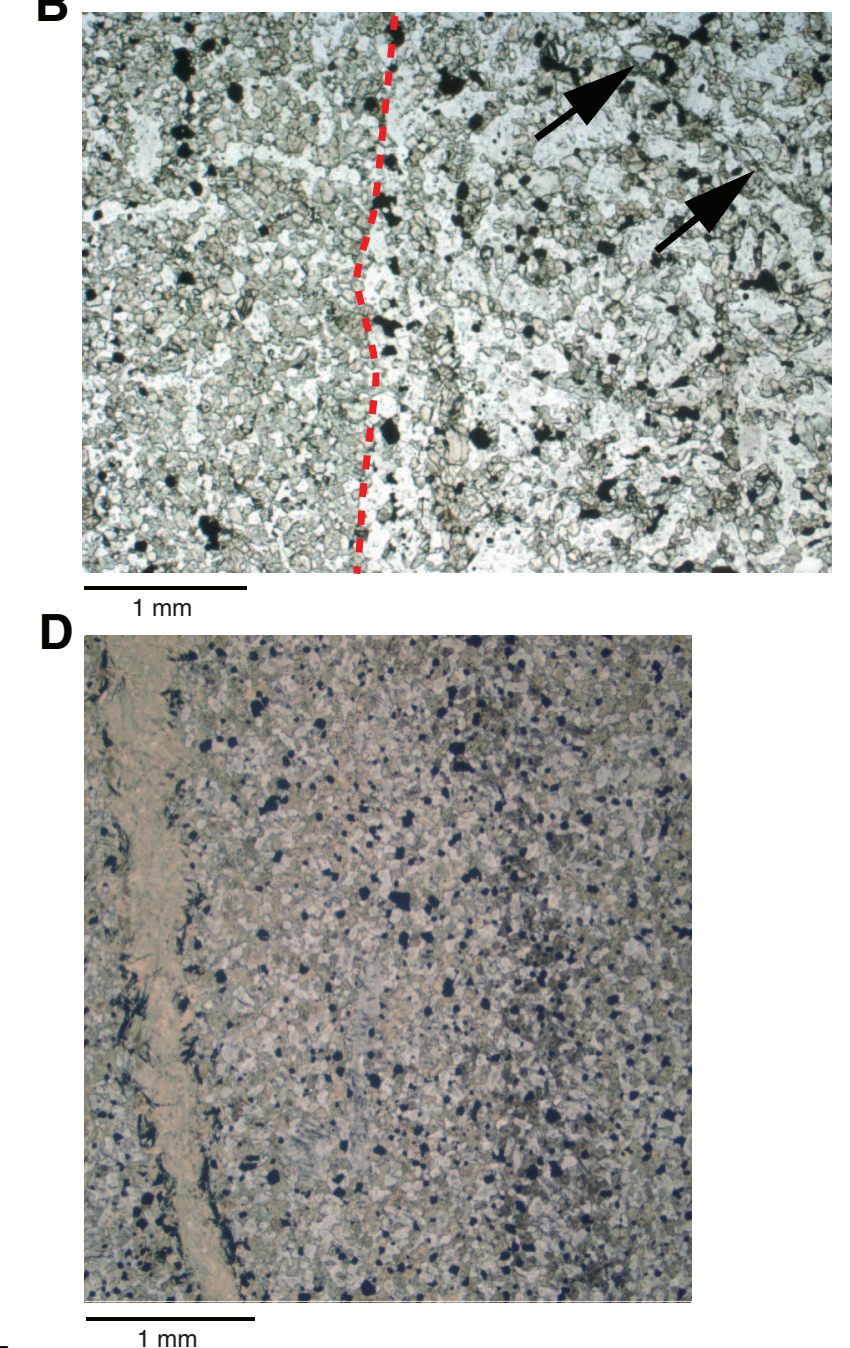

$\mathbf{F}$

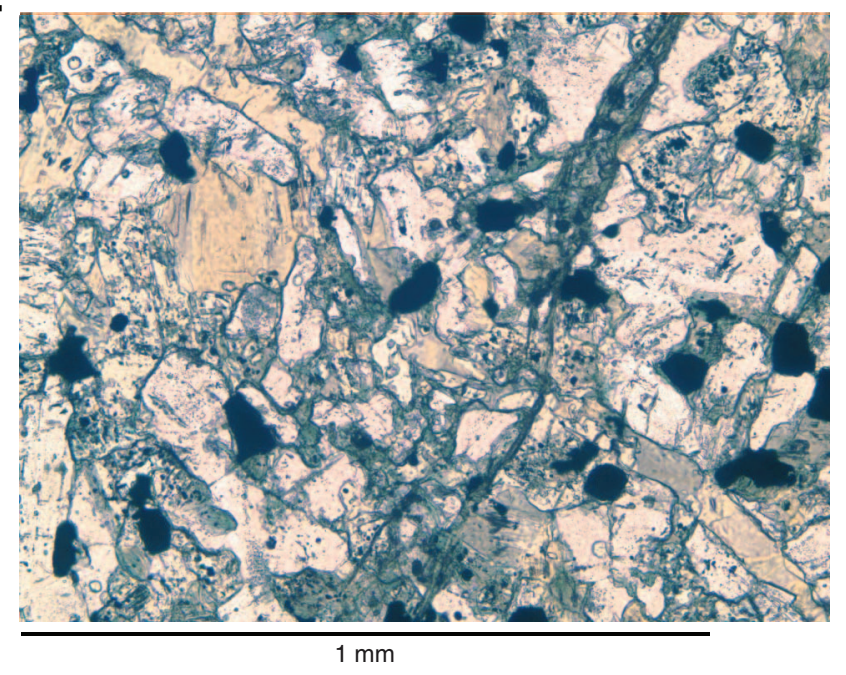


Figure F33. Thermal demagnetization of discrete Sample 335(312)-1256D-231R-1W, $115 \mathrm{~cm}$, from Gabbro 2, showing a clear two-component remanence structure (excluding the initial drilling-induced component). A negative inclination component that unblocks between $200^{\circ}$ and $500^{\circ} \mathrm{C}$ and a positive inclination component that unblocks between $500^{\circ}$ and $580^{\circ} \mathrm{C}$ are antipodal, indicating remanence acquisition during different geomagnetic polarity periods. Solid circles $=$ projection onto the horizontal plane, open circles $=$ projection onto either the vertical north-south or east-west planes.

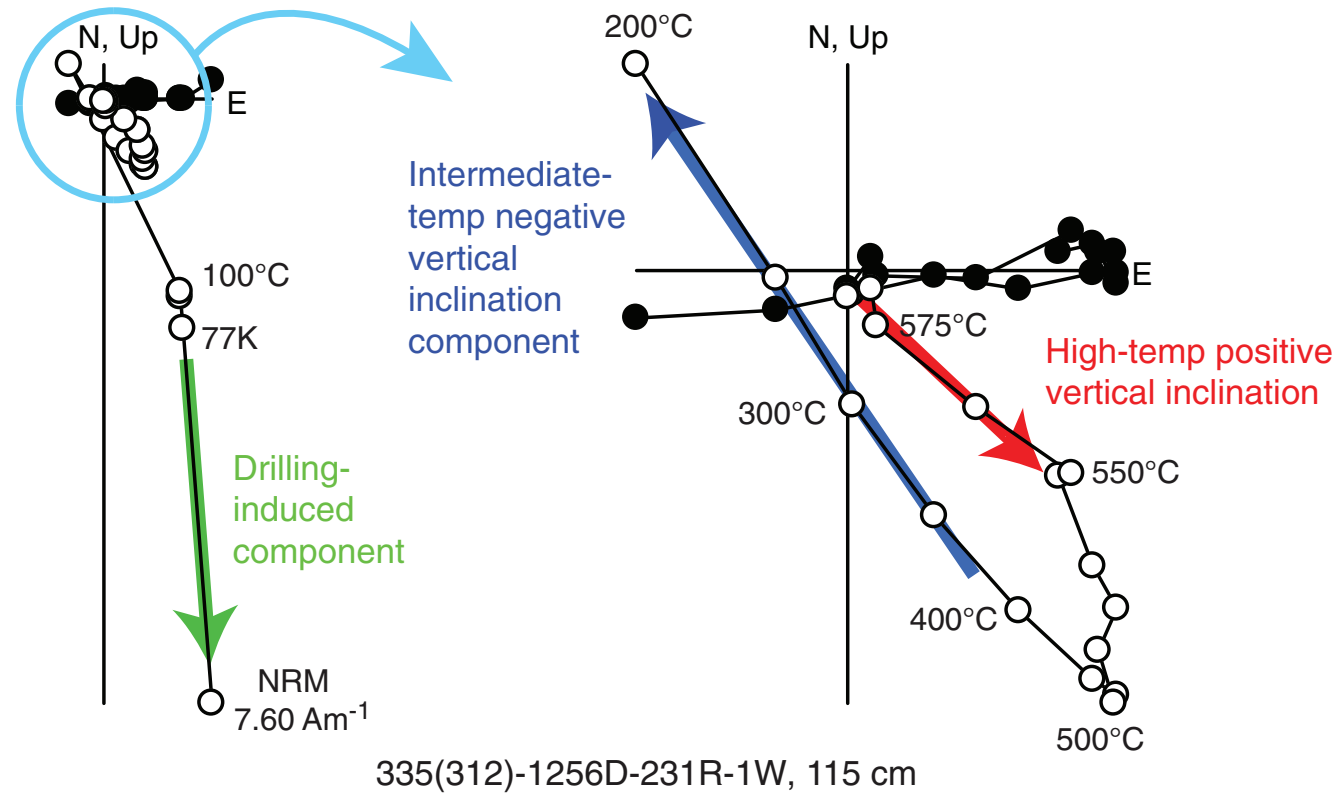


Figure F34. Anisotropy of low-field magnetic susceptibility (AMS) data from discrete samples from Hole 1256D (from top of Gabbro 1 downward). A. Data in the azimuthally unoriented IODP core reference frame, showing a random distribution. B. Data after restoration of ChRM declinations to a common north, resulting in a coherent fabric. C. Samples with prolate AMS fabrics, which have a pronounced north-south orientation of maximum principal axes (magnetic lineation).

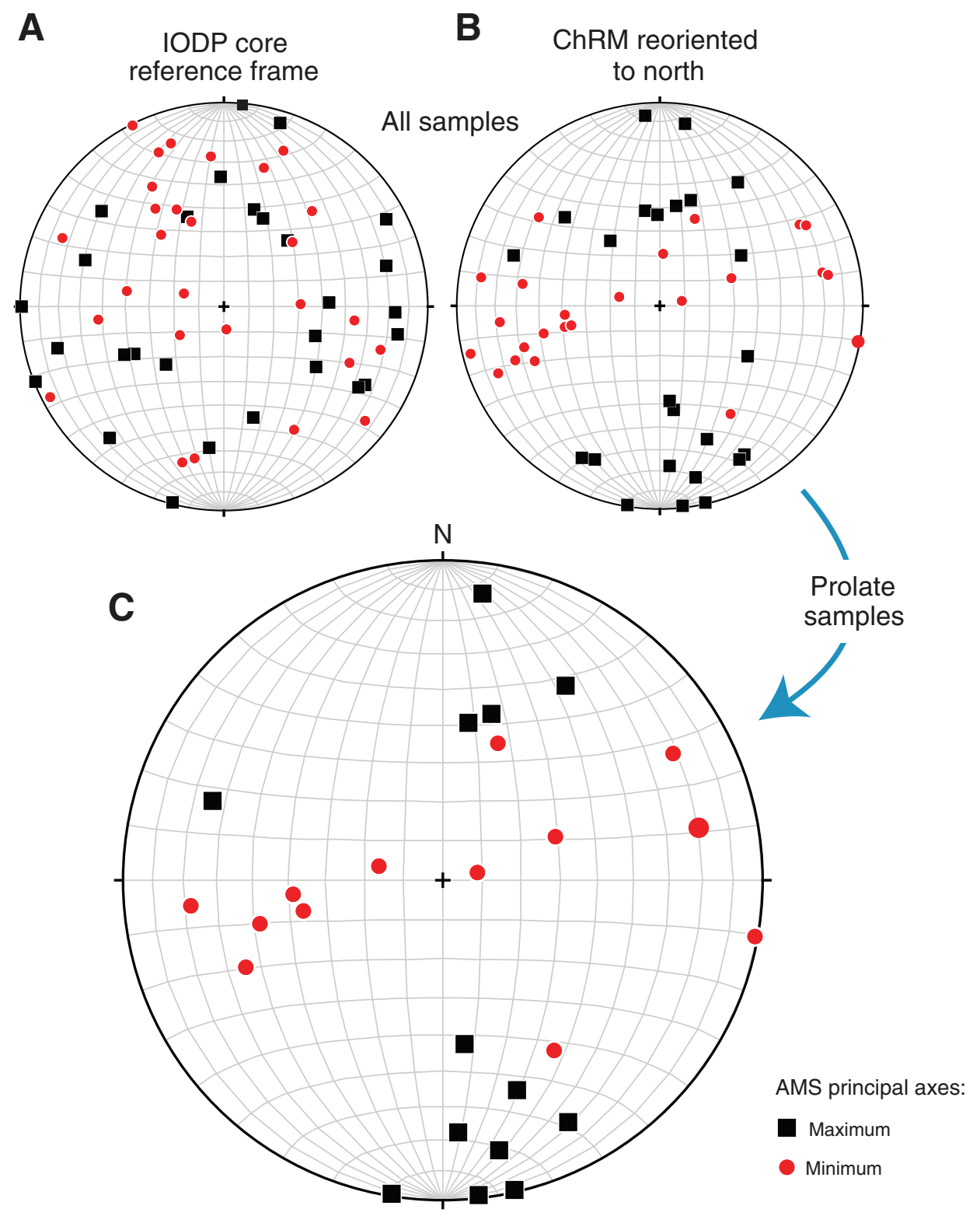


Figure F35. Downhole summary of Expedition 335(312) archive section half and Expedition 335 whole-round sections measured by the Whole-Round Multisensor Logger (WRMSL), Section Half Multisensor Logger (SHMSL), and Natural Gamma Radiation Logger (NGRL). Pale symbols show the raw data; points with strong colors are the results after eliminating data for gaps between pieces.

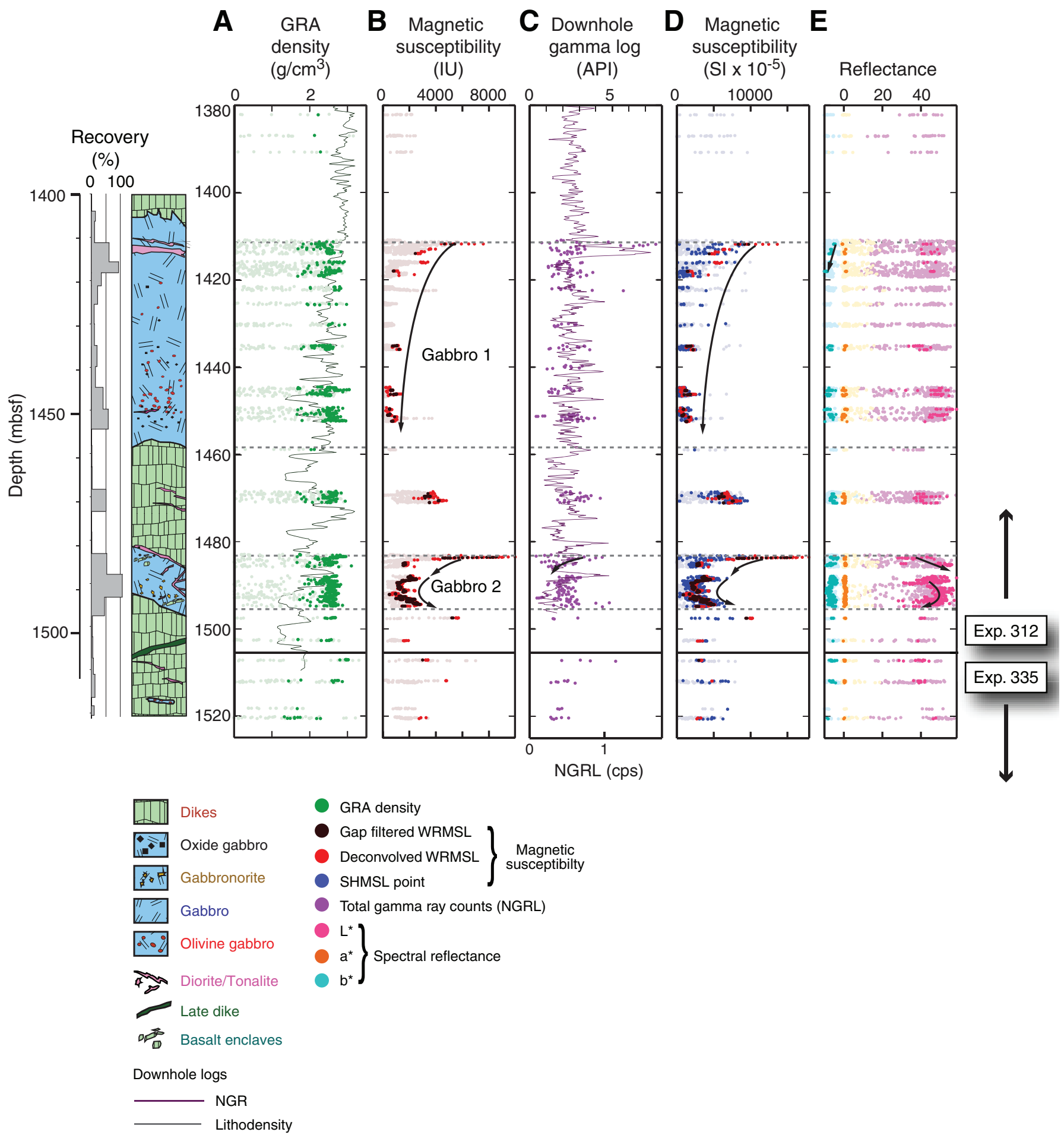


Figure F36. $P$-wave velocity for discrete samples from Expeditions 312 and 335. Solid diamonds are revised velocities for gabbro samples from core measured onboard during Expedition 335, whereas colored solid circles are measurements from non-core samples plotted at the depth from which they were recovered. Colors indicate the measurement direction in the standard IODP core reference frame where red, green, and blue are the $x_{-}, y_{-}$, and $z$-directions respectively. For non-core samples, directions were assigned with respect to the cut faces. Expedition 335 samples were submerged in seawater during measurement and are deemed to be more representative of in situ conditions than measurements made during Expedition 312 (solid black circles). Open circles represent shore-based measurements from Violay et al. (2010). The downhole sonic log (Guérin et al., 2008) is also shown for comparison.

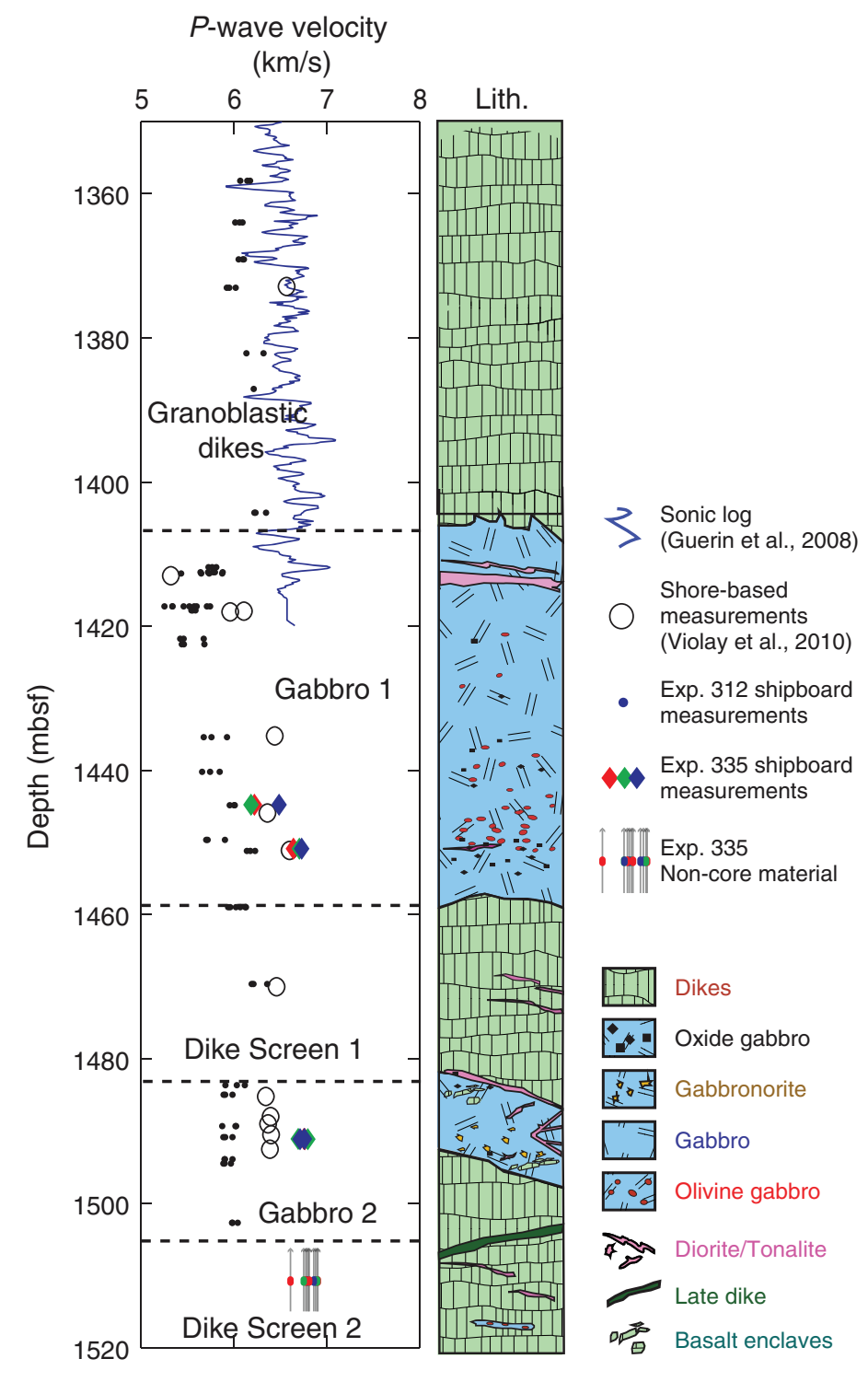


Figure F37. Summary of downhole logs recorded during Expedition 335 in Hole 1256D. Hole size was measured by the caliper of the HLDS density sonde. Lithostratigraphy is based on observations made during Expedition 309/312 and on refinements made during Expedition 335 below 1400 mbsf (see "Igneous petrology"). MAD $=$ moisture and density measurements on discrete samples, EDTCB = enhanced digital telemetry cartridge, MTT $=$ modular temperature tool.

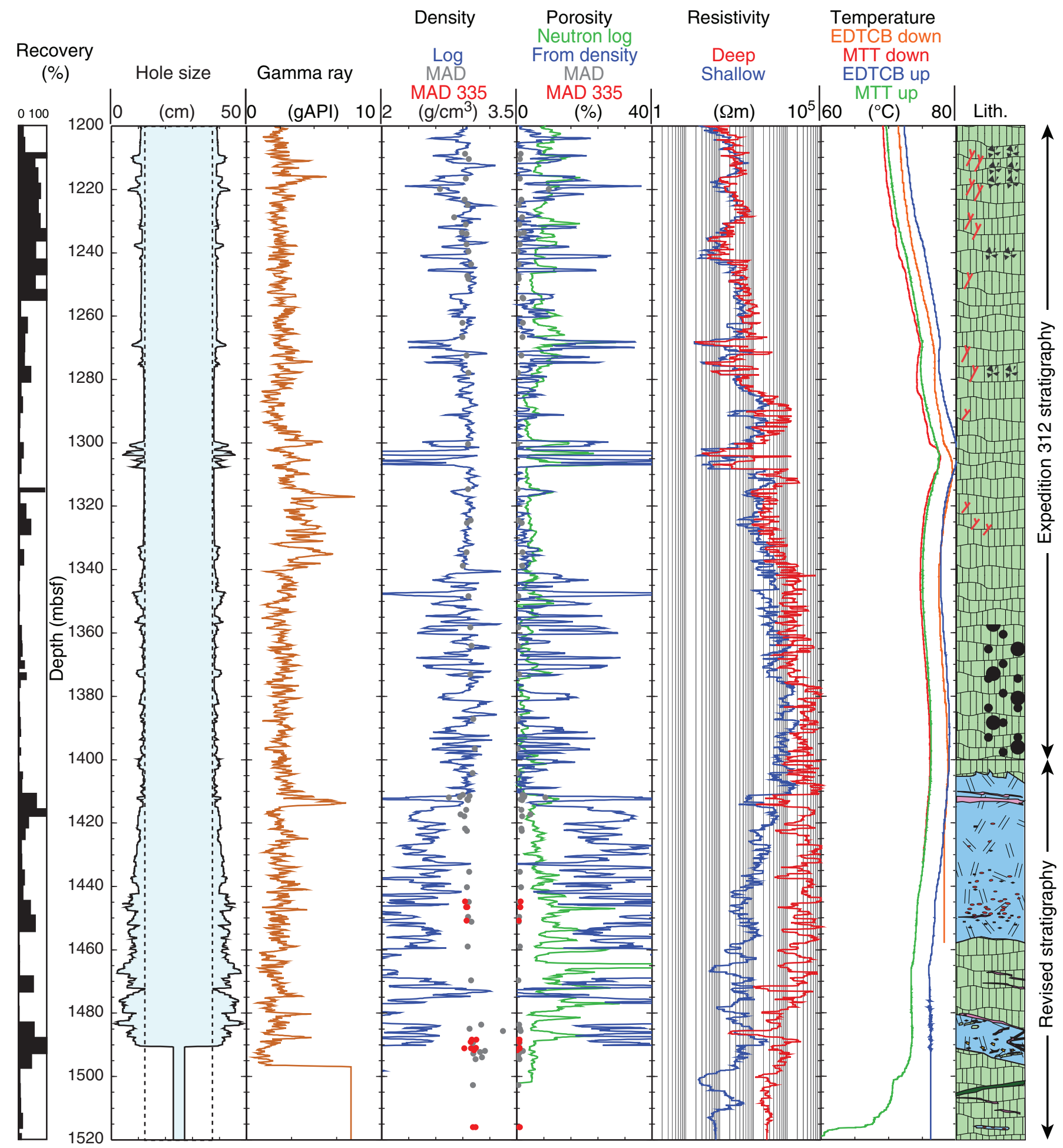


Figure F38. Comparison of hole size between 880 and 980 mbsf, measured by the caliper of the HLDS density sonde at the end of Expeditions 312 and 335. This part of the hole was cemented during Expedition 335 (see Fig. F23).

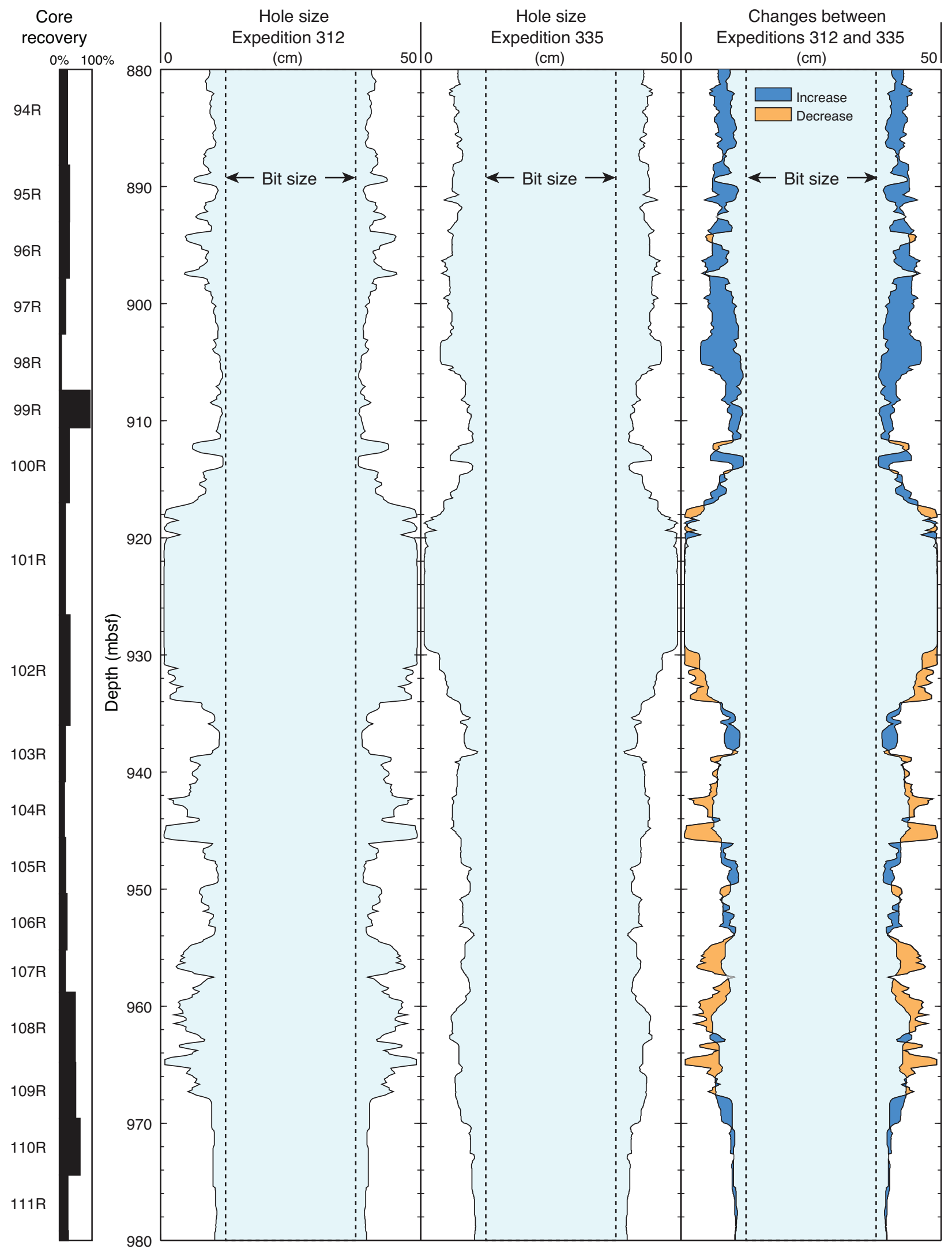


Figure F39. Temperature logs recorded during Expedition 335 compared with previous temperature logs in Hole 1256D. Lithostratigraphy is based on observations made during Expedition 309/312. MAD = moisture and density, $\mathrm{EDTCB}=$ enhanced digital telemetry cartridge, $\mathrm{MTT}=$ modular temperature tool, $\mathrm{TAP}=$ Temperature/ Acceleration/Pressure tool. See Figure F26 for key to lithology column.

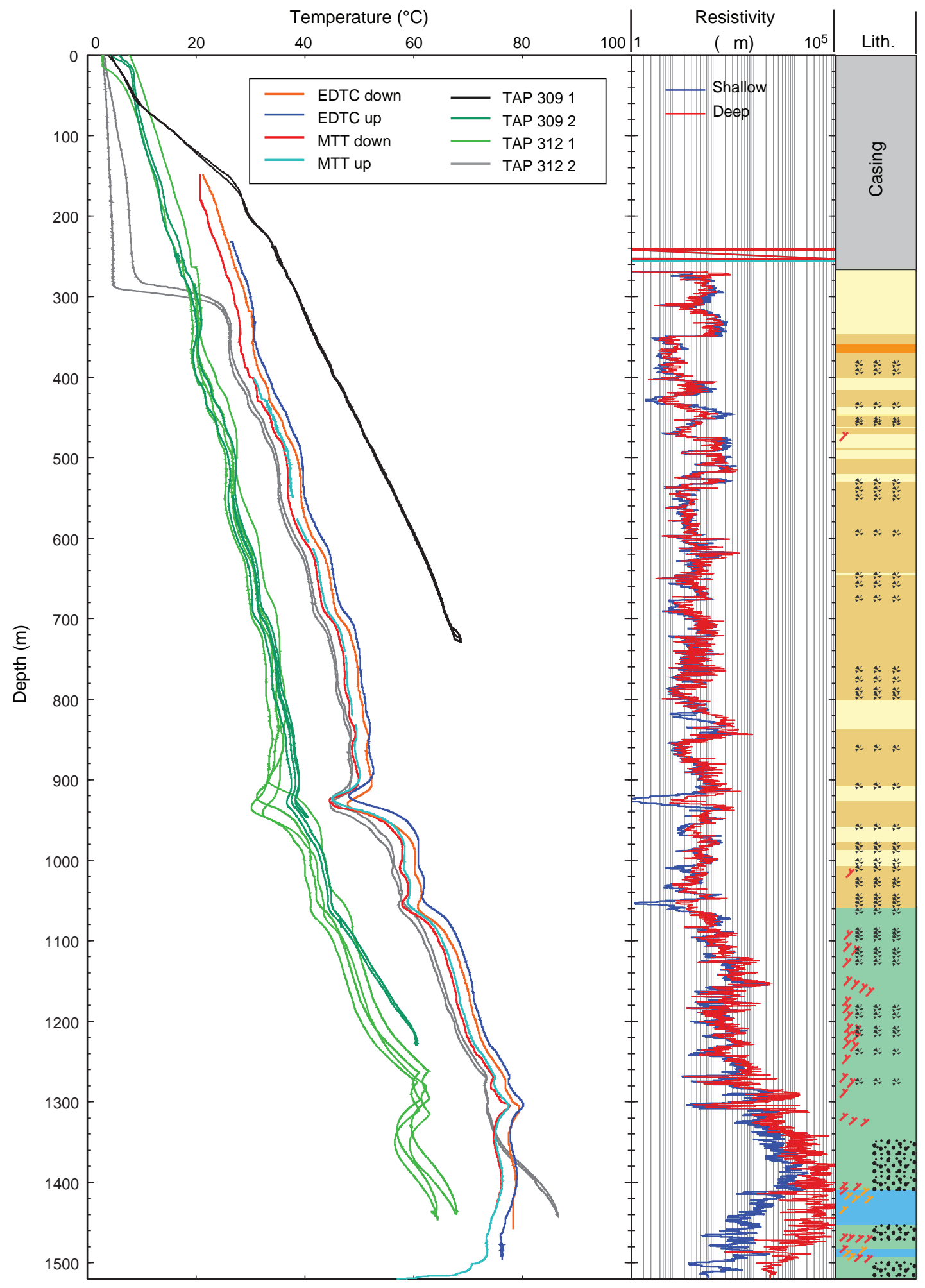


Table T1. Predicted and actual depths to gabbros at Site 1256.

\begin{tabular}{|c|c|c|c|c|c|c|c|c|c|c|c|c|}
\hline & \multicolumn{2}{|c|}{$\begin{array}{c}\text { Depth to axial } \\
\text { low-velocity zone }\end{array}$} & \multicolumn{2}{|c|}{$\begin{array}{c}100 \mathrm{~m} \text { of } \\
\text { off-axis lavas }\end{array}$} & \multicolumn{2}{|c|}{$\begin{array}{c}300 \mathrm{~m} \text { of } \\
\text { off-axis lavas }\end{array}$} & \multicolumn{2}{|c|}{$\begin{array}{c}450 \mathrm{~m} \text { of } \\
\text { off-axis lavas }\end{array}$} & \multicolumn{2}{|c|}{$\begin{array}{c}575 \mathrm{~m} \text { of } \\
\text { off-axis lavas }\end{array}$} & \multicolumn{2}{|c|}{$\begin{array}{c}\text { Actual } \\
\text { depth to gabbro }\end{array}$} \\
\hline & $\mathrm{msb}$ & mbsf & $\mathrm{msb}$ & mbsf & $\mathrm{msb}$ & mbsf & $\mathrm{msb}$ & mbsf & $\mathrm{msb}$ & mbsf & $\mathrm{msb}$ & mbsf \\
\hline Minimum & 725 & 975 & 825 & 1075 & 1025 & 1275 & 1175 & 1425 & 1300 & 1550 & 1157 & 1407 \\
\hline Maximum & 1000 & 1250 & 1100 & 1350 & 1300 & 1550 & 1450 & 1700 & 1575 & 1825 & - & - \\
\hline
\end{tabular}

Depths to the axial low-velocity zone estimated from the relationship with spreading rate shown in Figure F5 (following Purdy et al., 1992 , and Carbotte et al., 1997) for ocean crust spreading at $200 \mathrm{~mm} / \mathrm{y}$. The thickness of off-axis lavas estimated on textural grounds from cores recovered during Leg 206 was $284 \mathrm{~m}$. Greater thicknesses of off-axis lavas have been estimated from wireline imaging logs from the occurrence of a pillow lava-rich zone between 700 and 825 mbsf in Hole 1256D (Tominaga and Umino, 2010). The actual depth where the first gabbro (Gabbro 1) was recovered was $\sim 1407 \mathrm{mbsf}(1157 \mathrm{msb})$. This is in excellent agreement with the observed relationship between spreading rate and depth to axial low-velocity zones and the thickness of off-axis lavas estimated from Hole 1256D. Depths in mbsf include the $250 \mathrm{~m}$ thick sediment cover at Site 1256. $-=$ not available.

Table T2. Rates of recovery and rate of penetration (ROP) in Hole 1256D during Leg 206 and Expeditions 309/ 312 and 335.

\begin{tabular}{lrrr}
\hline \multicolumn{1}{c}{ Interval } & $\begin{array}{c}\text { Cored } \\
\text { interval (m) }\end{array}$ & $\begin{array}{c}\text { Average } \\
\text { recovery (\%) }\end{array}$ & $\begin{array}{c}\text { Average } \\
\text { ROP (m/h) }\end{array}$ \\
\hline Leg 206 and Expedition 309/312: & 1231 & 37 & 1.3 \\
$\quad$ Hole 1256D (Cores 2R-234R) & 785 & 41 & 1.5 \\
Lavas and transition zone (Cores 2R-128R) & 287 & 37 & 0.9 \\
Upper dikes (Cores 129R-191R) & 63 & 7 & 0.5 \\
Granoblastic dikes (Cores 192R-213R) & 96 & 29 & 1.1 \\
Plutonic section (Cores 214R-234R) & 72 & 35 & 1.2 \\
Gabbros (Gabbro 1: Cores 214R-224R; Gabbro 2: Cores 230R to 232R-2, 98 cm) & 24 & 11 & 0.9 \\
Dike Screen 1 (granoblastic basalt) & & & \\
Expedition 335: & 26.7 & 11 & 0.9 \\
Dike Screen 2 (granoblastic basalt) Cores 232R-2 through 239R (1507.1-1521.6 mbsf) & 1245.5 & 37 & 1.3 \\
Cumulative Hole 1256D (Cores 2R-239R) & & & \\
\hline
\end{tabular}


Table T3. Expedition 335 operation summary. (Continued on next 12 pages.)

\begin{tabular}{|c|c|c|c|c|c|c|c|}
\hline \multirow[b]{3}{*}{ Operation } & \multicolumn{2}{|c|}{ Start } & \multicolumn{4}{|c|}{ Expedition (from departure time) } & \multirow[b]{3}{*}{ Comments } \\
\hline & \multirow{2}{*}{$\begin{array}{l}\text { Local } \\
\text { time }(h)\end{array}$} & \multirow{2}{*}{$\begin{array}{l}\text { Date } \\
(2011)\end{array}$} & \multicolumn{2}{|c|}{ Duration } & \multicolumn{2}{|c|}{ Time (cumulative) } & \\
\hline & & & $\mathrm{h}$ & day & $\mathrm{h}$ & day & \\
\hline In Puntarenas, Costa Rica, for port call activities. & & $14 \mathrm{Apr}$ & & & & & Beginning of Expedition 335. \\
\hline Depart Puntarenas; transit to Site 1256. & 430 & $17 \mathrm{Apr}$ & 44.75 & 1.86 & 44.75 & 1.86 & $11.3 \mathrm{kt}$ at $0630 \mathrm{~h}$ on 18 April. \\
\hline $\begin{array}{l}\text { On position over Hole 1256D. Pick up mouse hole, make up BHA with } \\
\text { tricone bit and MBR. RIH drill string to } 2733 \text { mbrf while measuring and } \\
\text { rabbiting all tubulars. }\end{array}$ & 115 & 19 Apr & 9.00 & 0.38 & 53.75 & 2.24 & Start Run 1: Smith 9-7/8 inch F9 tricone bit. \\
\hline Launch VIT. & 1015 & 19 Apr & 0.75 & 0.03 & 54.50 & 2.27 & \\
\hline RIH drill string 2733-3246 mbrf. & 1100 & $19 \mathrm{Apr}$ & 1.25 & 0.05 & 55.75 & 2.32 & \\
\hline Lose VIT signal; retrieve VIT and repair cable head; redeploy VIT. & 1215 & $19 \mathrm{Apr}$ & 3.25 & 0.14 & 59.00 & 2.46 & \\
\hline RIH drill string 3246-3637 mbrf. & 1530 & $19 \mathrm{Apr}$ & 2.00 & 0.08 & 61.00 & 2.54 & \\
\hline Search and position vessel for reentry; reenter Hole 1256D at $1800 \mathrm{~h}$. & 1730 & 19 Apr & 0.50 & 0.02 & 61.50 & 2.56 & Reentry 1. \\
\hline Continue RIH to 258.8 mbsf. & 1800 & $19 \mathrm{Apr}$ & 1.25 & 0.05 & 62.75 & 2.61 & \\
\hline Recover VIT. & 1915 & $19 \mathrm{Apr}$ & 0.75 & 0.03 & 63.50 & 2.65 & \\
\hline $\begin{array}{l}\text { Continue RIH with } 5-1 / 2 \text { inch DP to } 925.0 \mathrm{mbsf} \text {, where formation took } \\
25,000 \mathrm{lb} \text {. Cancel temperature log and water sample. }\end{array}$ & 2000 & $19 \mathrm{Apr}$ & 1.75 & 0.07 & 65.25 & 2.72 & \\
\hline Pull back in hole $925.0-891.9$ mbsf. & 2145 & 19 Apr & 0.25 & 0.01 & 65.50 & 2.73 & Obstruction. \\
\hline Pick up $20 \mathrm{ft}$ knobby and top drive. & 2200 & $19 \mathrm{Apr}$ & 0.75 & 0.03 & 66.25 & 2.76 & \\
\hline RIH with top drive to 920.0 mbsf. & 2245 & 19 Apr & 0.75 & 0.03 & 67.00 & 2.79 & \\
\hline $\begin{array}{l}\text { Work pipe at } 920-925 \text { mbsf, where we had hole problems during Exp. } \\
312 \text {. Erratic torque; top drive current }=500 \mathrm{~A} \text {. }\end{array}$ & 2330 & $19 \mathrm{Apr}$ & 1.75 & 0.07 & 68.75 & 2.86 & \\
\hline Pull back $920-891.5$ mbsf. & 115 & $20 \mathrm{Apr}$ & 0.25 & 0.01 & 69.00 & 2.88 & \\
\hline Change out swivel packing. & 130 & $20 \mathrm{Apr}$ & 1.25 & 0.05 & 70.25 & 2.93 & \\
\hline $\begin{array}{l}\text { Resume washing/reaming } 891.5-923.3 \text { mbsf. Work stuck pipe } 0415- \\
0515 \mathrm{~h} \text { when rotation lost. Unable to apply }>10,000 \mathrm{lb} \text { WOB without } \\
\text { stalling top drive. Circulate } 600 \text { bbl of hi-vis gel during } 24 \mathrm{~h} \text { period. } \\
\text { Unable to penetrate deeper than } 923.3 \text { mbsf. Pump } 150 \text { bbl sweep at } \\
923.3 \text { mbsf. Trip drill string to change to a tricone bit with a more } \\
\text { aggressive cutting structure. }\end{array}$ & 245 & $20 \mathrm{Apr}$ & 27.25 & 1.14 & 97.50 & 4.06 & \\
\hline POOH with top drive $923.3-833.9$ mbsf. & 600 & $21 \mathrm{Apr}$ & 0.75 & 0.03 & 98.25 & 4.09 & \\
\hline Rack top drive. & 645 & $21 \mathrm{Apr}$ & 0.50 & 0.02 & 98.75 & 4.11 & \\
\hline $\begin{array}{l}\text { POOH from } 833.9 \text { mbsf and clear seafloor at } 0900 \mathrm{~h} \text {. Rack } 4 \text { stands of } \\
\text { DC in derrick. Lay out BHA with MBR. Bit clears rotary table at } 1550 \mathrm{~h} \text {. }\end{array}$ & 715 & $21 \mathrm{Apr}$ & 8.50 & 0.35 & 107.25 & 4.47 & Clear seafloor at $0900 \mathrm{~h}$. End Run 1 at $1550 \mathrm{~h}$. \\
\hline $\begin{array}{l}\text { Make up new Reed } 9-7 / 8 \text { inch tricone bit, bit sub with float valve, and } \\
\text { tandem set of boot baskets; RIH DP to } 2877 \text { mbrf. }\end{array}$ & 1545 & $21 \mathrm{Apr}$ & 6.75 & 0.28 & 114.00 & 4.75 & $\begin{array}{l}\text { Start Run 2: Reed 9-7/8 inch tricone bit (IADC Type 517) plus boot } \\
\text { baskets. }\end{array}$ \\
\hline Deploy VIT. & 2230 & $21 \mathrm{Apr}$ & 0.75 & 0.03 & 114.75 & 4.78 & \\
\hline Resume RIH drill string to 3638 mbrf. & 2315 & $21 \mathrm{Apr}$ & 1.50 & 0.06 & 116.25 & 4.84 & \\
\hline Position vessel and reenter Hole $1256 \mathrm{D}$ at $0105 \mathrm{~h}$. & 045 & $22 \mathrm{Apr}$ & 0.50 & 0.02 & 116.75 & 4.86 & Reentry 2. \\
\hline RIH to 259.3 mbsf. & 115 & $22 \mathrm{Apr}$ & 0.25 & 0.01 & 117.00 & 4.88 & \\
\hline Retrieve and recover VIT. & 130 & $22 \mathrm{Apr}$ & 1.00 & 0.04 & 118.00 & 4.92 & \\
\hline Resume RIH 259.3-892.1 mbsf. & 230 & $22 \mathrm{Apr}$ & 1.75 & 0.07 & 119.75 & 4.99 & \\
\hline Pick up top drive. & 415 & $22 \mathrm{Apr}$ & 0.50 & 0.02 & 120.25 & 5.01 & \\
\hline $\begin{array}{l}\text { Wash/ream hole from } 892.1 \text { mbsf. Attempt to pass bridge at } 920 \text { mbsf. } \\
\text { Pump } 50 \text { bbl hi-vis mud sweep. }\end{array}$ & 445 & $22 \mathrm{Apr}$ & 1.75 & 0.07 & 122.00 & 5.08 & \\
\hline Work stuck pipe. & 630 & $22 \mathrm{Apr}$ & 1.25 & 0.05 & 123.25 & 5.14 & Stuck. \\
\hline Wash/ream hole from 920 mbsf. Circulate $100 \mathrm{bbl}$ hi-vis mud sweep. & 745 & $22 \mathrm{Apr}$ & 2.25 & 0.09 & 125.50 & 5.23 & \\
\hline Work stuck pipe. & 1000 & $22 \mathrm{Apr}$ & 2.00 & 0.08 & 127.50 & 5.31 & Stuck. \\
\hline Wash/ream hole from 923 mbsf. Unable to pass bridge. & 1200 & $22 \mathrm{Apr}$ & 9.00 & 0.38 & 136.50 & 5.69 & \\
\hline Pull back in hole $923-863.3$ mbsf. & 2100 & $22 \mathrm{Apr}$ & 0.50 & 0.02 & 137.00 & 5.71 & \\
\hline Rack top drive. & 2130 & $22 \mathrm{Apr}$ & 0.50 & 0.02 & 137.50 & 5.73 & \\
\hline $\begin{array}{l}\mathrm{POOH} \text { drill string and clear seafloor at } 0005 \mathrm{~h} \text { and plane of the rotary } \\
\text { table at } 0605 \mathrm{~h} \text {. }\end{array}$ & 2200 & $22 \mathrm{Apr}$ & 8.00 & 0.33 & 145.50 & 6.06 & Clear seafloor at $0500 \mathrm{~h}$. End Run 2 at $0605 \mathrm{~h}$. \\
\hline
\end{tabular}




\begin{tabular}{|c|c|c|c|c|c|c|c|}
\hline \multirow[b]{3}{*}{ Operation } & \multicolumn{2}{|c|}{ Start } & \multicolumn{4}{|c|}{ Expedition (from departure time) } & \multirow[b]{3}{*}{ Comments } \\
\hline & \multirow{2}{*}{$\begin{array}{l}\text { Local } \\
\text { time }(h)\end{array}$} & \multirow{2}{*}{$\begin{array}{l}\text { Date } \\
(2011)\end{array}$} & \multicolumn{2}{|c|}{ Duration } & \multicolumn{2}{|c|}{ Time (cumulative) } & \\
\hline & & & $\mathrm{h}$ & day & $\mathrm{h}$ & day & \\
\hline $\begin{array}{l}\text { Lay out junk baskets and } 9-7 / 8 \text { inch bit. Junk baskets yielded some } \\
\text { basaltic cuttings ranging from small gravel to rounded pebbles. } \\
\text { Expedition } 312 \text { logs indicate a large washed-out zone at } 920-935 \\
\text { mbsf, which we will attempt to stabilize with a } 5 \text { bbl cement plug. }\end{array}$ & 600 & $23 \mathrm{Apr}$ & 1.00 & 0.04 & 146.50 & 6.10 & Samples Run02-EXJB. Decision to cement. \\
\hline $\begin{array}{l}\text { Make up cementing BHA with used Reed tricone bit without jets and } 2 \\
\text { stands of DC. Deploy to } 2676 \text { mbrf. }\end{array}$ & 700 & $23 \mathrm{Apr}$ & 6.00 & 0.25 & 152.50 & 6.35 & Start Run 3: Reed tricone without jets. \\
\hline Install VIT. & 1300 & $23 \mathrm{Apr}$ & 0.50 & 0.02 & 153.00 & 6.37 & \\
\hline Resume RIH 2676-3638 mbrf. & 1330 & $23 \mathrm{Apr}$ & 1.50 & 0.06 & 154.50 & 6.44 & \\
\hline Search and position vessel. Reenter Hole $1256 \mathrm{D}$ at $1520 \mathrm{~h}$. & 1500 & $23 \mathrm{Apr}$ & 0.25 & 0.01 & 154.75 & 6.45 & Reentry 3. \\
\hline RIH drill string to 262.9 mbsf. & 1515 & $23 \mathrm{Apr}$ & 0.50 & 0.02 & 155.25 & 6.47 & \\
\hline POOH VIT and recover. & 1545 & $23 \mathrm{Apr}$ & 1.50 & 0.06 & 156.75 & 6.53 & \\
\hline Resume RIH drill string. Tag bridge at 922 mbsf. & 1715 & $23 \mathrm{Apr}$ & 1.50 & 0.06 & 158.25 & 6.59 & \\
\hline $\begin{array}{l}\text { Make up circulating head and Lo-torque valves; pressure test to } 1500 \\
\text { psi. }\end{array}$ & 1845 & $23 \mathrm{Apr}$ & 0.50 & 0.02 & 158.75 & 6.61 & \\
\hline Pump $5 \mathrm{bbl}$ of $16 \mathrm{ppg}$ cement slurry. & 1915 & $23 \mathrm{Apr}$ & 0.25 & 0.01 & 159.00 & 6.62 & Pump cement. \\
\hline Displace drill string with seawater ( $1 \times$ volume). & 1930 & $23 \mathrm{Apr}$ & 0.50 & 0.02 & 159.50 & 6.65 & \\
\hline $\begin{array}{l}\text { Lay out circulating head and pull back in hole with drill string to } 806.9 \\
\text { mbsf. }\end{array}$ & 2000 & $23 \mathrm{Apr}$ & 0.50 & 0.02 & 160.00 & 6.67 & \\
\hline Flush drill string with seawater ( $3 \times$ volume). & 2030 & $23 \mathrm{Apr}$ & 1.25 & 0.05 & 161.25 & 6.72 & \\
\hline $\begin{array}{l}\text { Lay out circulating head and POOH to } 3191 \text { mbrf. Clear top of the cone } \\
\text { at } 2320 \mathrm{~h} \text {. Bit at rotary table at } 0515 \mathrm{~h} \text {. }\end{array}$ & 2145 & $23 \mathrm{Apr}$ & 7.50 & 0.31 & 168.75 & 7.03 & Clear seafloor at $2320 \mathrm{~h}$. End Run 3 at $0515 \mathrm{~h}$. \\
\hline $\begin{array}{l}\text { Make up new 9-7/8 inch Atlas tricone bit, inspect float, pick up } 2 \text { DC } \\
\text { stands from derrick, and install piccolo at } 199 \text { mbrf. }\end{array}$ & 515 & $24 \mathrm{Apr}$ & 1.50 & 0.06 & 170.25 & 7.09 & Start Run 4: 9-7/8 inch tricone bit (Atlas HP61). \\
\hline Service rig. & 645 & 24 Apr & 0.50 & 0.02 & 170.75 & 7.11 & \\
\hline Resume tripping drill string 199-1596 mbrf. & 715 & 24 Apr & 3.25 & 0.14 & 174.00 & 7.25 & \\
\hline Slip and cut $115 \mathrm{ft}$ of drilling line. & 1030 & $24 \mathrm{Apr}$ & 1.50 & 0.06 & 175.50 & 7.31 & \\
\hline Resume tripping drill string $1596-2731$ mbrf. & 1200 & 24 Apr & 2.50 & 0.10 & 178.00 & 7.42 & \\
\hline Deploy VIT. & 1430 & 24 Apr & 0.50 & 0.02 & 178.50 & 7.44 & \\
\hline Continue RIH DP 2731-3636 mbrf. & 1500 & $24 \mathrm{Apr}$ & 1.75 & 0.07 & 180.25 & 7.51 & \\
\hline Search and position vessel. Reenter Hole $1256 \mathrm{D}$ at $1655 \mathrm{~h}$. & 1645 & 24 Apr & 0.25 & 0.01 & 180.50 & 7.52 & Reentry 4. \\
\hline Continue RIH drill string to 315.7 mbsf. & 1700 & $24 \mathrm{Apr}$ & 0.50 & 0.02 & 181.00 & 7.54 & \\
\hline Recover VIT. & 1730 & 24 Apr & 0.75 & 0.03 & 181.75 & 7.57 & \\
\hline Continue RIH DP and tag bridge at $922 \mathrm{mbsf}$. & 1815 & $24 \mathrm{Apr}$ & 1.25 & 0.05 & 183.00 & 7.62 & \\
\hline Pull back in hole to 890.6 mbsf. & 1930 & $24 \mathrm{Apr}$ & 0.25 & 0.01 & 183.25 & 7.64 & \\
\hline Pick up top drive and RIH with same to 922.0 mbsf. & 1945 & $24 \mathrm{Apr}$ & 1.00 & 0.04 & 184.25 & 7.68 & \\
\hline $\begin{array}{l}\text { Attempt to wash/ream though bridge encountering high erratic torque; } \\
\text { top drive max current = } 650 \mathrm{~A} \text {. }\end{array}$ & 2045 & $24 \mathrm{Apr}$ & 1.00 & 0.04 & 185.25 & 7.72 & \\
\hline Pull back in hole with top drive to 890.6 mbsf. & 2145 & $24 \mathrm{Apr}$ & 0.50 & 0.02 & 185.75 & 7.74 & Decision to pump more cement. \\
\hline Rack top drive. & 2215 & $24 \mathrm{Apr}$ & 0.50 & 0.02 & 186.25 & 7.76 & \\
\hline $\begin{array}{l}\mathrm{POOH} \text { drill string from } 890.6 \text { to the surface. Clear seafloor at } 0030 \mathrm{~h} \text {. Bit } \\
\text { at rotary table at } 0615 \mathrm{~h} \text {. }\end{array}$ & 2245 & $24 \mathrm{Apr}$ & 7.50 & 0.31 & 193.75 & 8.07 & Clear seafloor at $0300 \mathrm{~h}$. End Run 4 at $0615 \mathrm{~h}$. \\
\hline $\begin{array}{l}\text { Make up cementing bit (Reed type 517) without nozzles to } 2 \text { DC stands; } \\
\text { RIH to } 2661 \text { mbrf. }\end{array}$ & 615 & $25 \mathrm{Apr}$ & 6.00 & 0.25 & 199.75 & 8.32 & Start Run 5: cementing bit (Reed type 517). \\
\hline Deploy VIT. & 1215 & $25 \mathrm{Apr}$ & 0.50 & 0.02 & 200.25 & 8.34 & \\
\hline Resume RIH drill string 2661-3637.8 mbrf. & 1245 & $25 \mathrm{Apr}$ & 1.50 & 0.06 & 201.75 & 8.41 & \\
\hline Search and position vessel. Reenter Hole 1256D (Reentry 5) at $1445 \mathrm{~h}$. & 1415 & $25 \mathrm{Apr}$ & 0.50 & 0.02 & 202.25 & 8.43 & Reentry 5. \\
\hline Continue RIH drill string to 922 mbsf. & 1445 & $25 \mathrm{Apr}$ & 2.50 & 0.10 & 204.75 & 8.53 & \\
\hline Install circulating head. Pressure test cement system. & 1715 & $25 \mathrm{Apr}$ & 0.75 & 0.03 & 205.50 & 8.56 & \\
\hline Mix and pump $50 \mathrm{bbl}$ of 15 ppg cement slurry. & 1800 & $25 \mathrm{Apr}$ & 0.75 & 0.03 & 206.25 & 8.59 & Pump cement. \\
\hline Displace cement slurry with seawater. & 1845 & $25 \mathrm{Apr}$ & 0.25 & 0.01 & 206.50 & 8.60 & \\
\hline
\end{tabular}




\begin{tabular}{|c|c|c|c|c|c|c|c|}
\hline \multirow[b]{3}{*}{ Operation } & \multicolumn{2}{|c|}{ Start } & \multicolumn{4}{|c|}{ Expedition (from departure time) } & \multirow[b]{3}{*}{ Comments } \\
\hline & \multirow{2}{*}{$\begin{array}{l}\text { Local } \\
\text { time }(h)\end{array}$} & \multirow{2}{*}{$\begin{array}{l}\text { Date } \\
(2011)\end{array}$} & \multicolumn{2}{|c|}{ Duration } & \multicolumn{2}{|c|}{ Time (cumulative) } & \\
\hline & & & $\mathrm{h}$ & day & $\mathrm{h}$ & day & \\
\hline Lay out circulating head and pull back in hole to 720.5 mbsf. & 1900 & $25 \mathrm{Apr}$ & 0.75 & 0.03 & 207.25 & 8.64 & \\
\hline Circulate and flush drill pipe with seawater ( $3 \times$ drill string volume). & 1945 & $25 \mathrm{Apr}$ & 1.00 & 0.04 & 208.25 & 8.68 & \\
\hline $\begin{array}{l}\text { POOH drill string to surface. Clear the top of the cone at } 2215 \mathrm{~h} \text {. Bit at } \\
\text { rotary table at } 0345 \mathrm{~h} \text {. }\end{array}$ & 2045 & $25 \mathrm{Apr}$ & 7.00 & 0.29 & 215.25 & 8.97 & Clear seafloor at $2215 \mathrm{~h}$. End Run 5 at $0345 \mathrm{~h}$. \\
\hline $\begin{array}{l}\text { Lay down Reed bit and pick up 9-7/8 inch Atlas HP61 tricone bit with } \\
\text { tandem set of boot baskets and } 2 \text { DC stands; RIH to } 200.6 \text { mbrf. }\end{array}$ & 345 & $26 \mathrm{Apr}$ & 1.75 & 0.07 & 217.00 & 9.04 & Start Run 6: 9-7/8 inch Atlas HP61 tricone bit plus boot baskets. \\
\hline Service rig: drawworks, crown, pipe stabber, traveling block, and dollies. & 530 & $26 \mathrm{Apr}$ & 0.50 & 0.02 & 217.50 & 9.06 & \\
\hline Resume RIH 2676-3533 mbrf. & 600 & $26 \mathrm{Apr}$ & 7.50 & 0.31 & 225.00 & 9.37 & \\
\hline Deploy VIT. & 1330 & $26 \mathrm{Apr}$ & 0.50 & 0.02 & 225.50 & 9.40 & \\
\hline RIH drill string 3533-3638 mbrf. & 1400 & $26 \mathrm{Apr}$ & 1.00 & 0.04 & 226.50 & 9.44 & \\
\hline Search and position vessel. Reenter Hole 1256D (Reentry 6) at $1520 \mathrm{~h}$. & 1500 & $26 \mathrm{Apr}$ & 0.25 & 0.01 & 226.75 & 9.45 & Reentry 6. \\
\hline Resume RIH drill string to $661.8 \mathrm{mbsf}$. & 1515 & $26 \mathrm{Apr}$ & 1.75 & 0.07 & 228.50 & 9.52 & \\
\hline Recover VIT. & 1700 & $26 \mathrm{Apr}$ & 0.50 & 0.02 & 229.00 & 9.54 & \\
\hline RIH drill string; make firm contact with cement at 882.0 mbsf. & 1730 & $26 \mathrm{Apr}$ & 0.75 & 0.03 & 229.75 & 9.57 & \\
\hline Pick up top drive. & 1815 & $26 \mathrm{Apr}$ & 0.50 & 0.02 & 230.25 & 9.59 & \\
\hline $\begin{array}{l}\text { Drill out cement } 882.0-922.0 \text { mbsf. Circulate } 40 \text { bbl gel sweep at } 904.6 \\
\text { mbsf. }\end{array}$ & 1845 & $26 \mathrm{Apr}$ & 3.75 & 0.16 & 234.00 & 9.75 & \\
\hline $\begin{array}{l}\text { Attempt to drill though bridge with high erratic torque. Circulate } 50 \text { bbl } \\
\text { gel sweep at } 922 \text { mbsf. Continue to wash/ream at } 922.0 \text { mbsf. Top } \\
\text { drive max current = } 650 \mathrm{~A} \text {. }\end{array}$ & 2230 & $26 \mathrm{Apr}$ & 3.00 & 0.13 & 237.00 & 9.87 & \\
\hline $\begin{array}{l}\text { Work stuck pipe at } \sim 923 \text { mbsf. Top drive max current }=800 \mathrm{~A} \text {, overpull }= \\
120,000 \mathrm{lb} \text {. }\end{array}$ & 130 & $27 \mathrm{Apr}$ & 1.00 & 0.04 & 238.00 & 9.92 & \\
\hline $\begin{array}{l}\text { Resume washing/reaming ledge at } 922 \text { mbsf with high rotary speed, } \\
\text { high pump, and lighter WOB. We appeared to be making progress } \\
\text { mid-morning only to lose it later in the day which may indicate that } \\
\text { the obstruction is shifting. Circulate multiple } 50 \text { bbl hi-vis gel sweeps } \\
\text { at } 922 \text { mbsf. Continue to wash/ream obstruction at } 921.6 \text { mbsf (tide } \pm \\
0.5 \mathrm{~m} \text { ). Circulate } 100 \mathrm{bbl} \text { hi-vis gel sweep at } 922.0 \text { mbsf. }\end{array}$ & 230 & $27 \mathrm{Apr}$ & 27.50 & 1.15 & 265.50 & 11.06 & \\
\hline Pull back with top drive $921.6-834.5$ mbsf. & 600 & $28 \mathrm{Apr}$ & 0.75 & 0.03 & 266.25 & 11.09 & \\
\hline Rack top drive. & 645 & $28 \mathrm{Apr}$ & 0.50 & 0.02 & 266.75 & 11.11 & \\
\hline $\begin{array}{l}\text { POOH from } 834.5 \text { mbsf and clear seafloor at } 0850 \mathrm{~h} \text {. Set back DC stands } \\
\text { in the derrick and lay out junk baskets. Bit is at the rotary table at } 1455 \\
\text { h. Lay out used bit in good condition with no appreciable shirttail } \\
\text { wear, with all teeth intact, and exhibiting very little wear. }\end{array}$ & 715 & $28 \mathrm{Apr}$ & 7.75 & 0.32 & 274.50 & 11.44 & Clear seafloor at $0850 \mathrm{~h}$. End Run 6 at 1455 h. Samples Run06-EXJB. \\
\hline $\begin{array}{l}\text { Make up new Smith tricone bit, bit sub with float, and } 4 \text { DC stands; RIH } \\
\text { drill string to } 2759 \text { mbrf. }\end{array}$ & 1500 & $28 \mathrm{Apr}$ & 5.75 & 0.24 & 280.25 & 11.68 & Start Run 7: Smith tricone bit. \\
\hline Slip and cut $115 \mathrm{ft}$ of drilling line. & 2045 & $28 \mathrm{Apr}$ & 1.50 & 0.06 & 281.75 & 11.74 & \\
\hline Install VIT. & 2215 & $28 \mathrm{Apr}$ & 0.50 & 0.02 & 282.25 & 11.76 & \\
\hline Resume RIH drill string 2759-3640 mbrf. Fill DP every 10 stands. & 2245 & $28 \mathrm{Apr}$ & 2.00 & 0.08 & 284.25 & 11.84 & \\
\hline $\begin{array}{l}\text { Space out and position vessel to reenter Hole } 1256 \mathrm{D} \text { at } 0135 \mathrm{~h} \text { (Reentry } \\
7 \text { ). }\end{array}$ & 045 & $29 \mathrm{Apr}$ & 0.75 & 0.03 & 285.00 & 11.88 & Reentry 7. \\
\hline RIH to 228.2 mbsf. & 130 & 29 Apr & 1.50 & 0.06 & 286.50 & 11.94 & \\
\hline Retrieve and recover VIT. & 300 & $29 \mathrm{Apr}$ & 0.50 & 0.02 & 287.00 & 11.96 & \\
\hline Resume RIH 228.2-861.4 mbsf. & 330 & $29 \mathrm{Apr}$ & 1.25 & 0.05 & 288.25 & 12.01 & \\
\hline Pick up top drive. & 445 & $29 \mathrm{Apr}$ & 0.50 & 0.02 & 288.75 & 12.03 & \\
\hline RIH top drive $861.4-921.9$ mbsf. & 515 & $29 \mathrm{Apr}$ & 1.00 & 0.04 & 289.75 & 12.07 & \\
\hline Attempt to pass obstruction with pump and no rotation. No advance. & 615 & $29 \mathrm{Apr}$ & 0.75 & 0.03 & 290.50 & 12.10 & \\
\hline $\begin{array}{l}\text { Resume washing/reaming, drill though obstruction at } 935.0 \mathrm{mbsf} \text {, and } \\
\text { advance } 921.9-941.5 \mathrm{mbsf} \text {. Circulate } 100 \mathrm{bbl} \text { gel sweep at } 931.0 \\
\text { mbsf. }\end{array}$ & 700 & $29 \mathrm{Apr}$ & 17.00 & 0.71 & 307.50 & 12.81 & Finally! \\
\hline
\end{tabular}




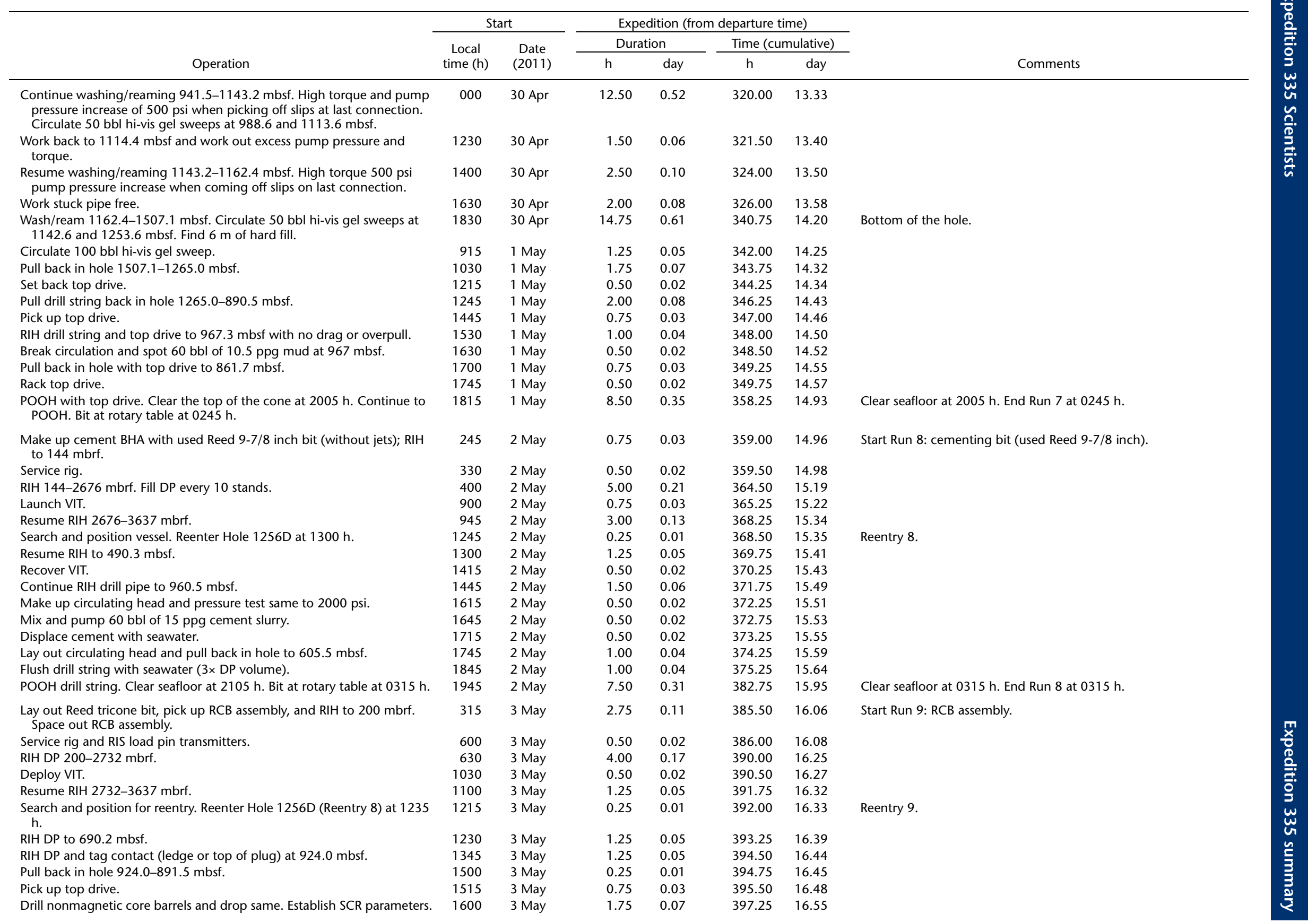




\begin{tabular}{|c|c|c|c|c|c|c|c|}
\hline \multirow[b]{3}{*}{ Operation } & \multicolumn{2}{|c|}{ Start } & \multicolumn{4}{|c|}{ Expedition (from departure time) } & \multirow[b]{3}{*}{ Comments } \\
\hline & \multirow{2}{*}{$\begin{array}{l}\text { Local } \\
\text { time }(h)\end{array}$} & \multirow{2}{*}{$\begin{array}{l}\text { Date } \\
(2011)\end{array}$} & \multicolumn{2}{|c|}{ Duration } & \multicolumn{2}{|c|}{ Time (cumulative) } & \\
\hline & & & $\mathrm{h}$ & day & $\mathrm{h}$ & day & \\
\hline Cut cement Cores 1G-5G (924.0-971.3 mbsf). & 1745 & 3 May & 12.25 & 0.51 & 409.50 & 17.06 & \\
\hline Pull back in hole to 833.9 mbsf. & 600 & 4 May & 0.75 & 0.03 & 410.25 & 17.09 & \\
\hline Rack top drive. & 645 & 4 May & 0.50 & 0.02 & 410.75 & 17.11 & \\
\hline Slip and cut $115 \mathrm{ft}$ of drilling line. & 715 & 4 May & 1.50 & 0.06 & 412.25 & 17.18 & \\
\hline Drop wash barrel. & 845 & 4 May & 0.25 & 0.01 & 412.50 & 17.19 & \\
\hline RIH 833.9-949.1 mbsf. & 900 & 4 May & 0.50 & 0.02 & 413.00 & 17.21 & \\
\hline Pick up top drive. & 930 & 4 May & 0.50 & 0.02 & 413.50 & 17.23 & \\
\hline Continue to RIH with top drive $949.1-971.3$ mbsf. & 1000 & 4 May & 0.50 & 0.02 & 414.00 & 17.25 & \\
\hline Round trip wash barrel and cut core 6G (971.3-980.9 mbsf). & 1030 & 4 May & 3.00 & 0.13 & 417.00 & 17.38 & \\
\hline $\begin{array}{l}\text { Drop wash barrel and wash } 980.9-1507.1 \text { mbsf. Note tight hole at } \\
1499.6-1501.1 \text { mbsf. Pump } 50 \text { bbl hi-sweeps at } 1154.6 \text { and } 1501.1 \\
\text { mbsf. }\end{array}$ & 1330 & 4 May & 9.25 & 0.39 & 426.25 & 17.76 & \\
\hline Circulate 50 bbl hi-vis gel sweep. & 2245 & 4 May & 1.00 & 0.04 & 427.25 & 17.80 & \\
\hline $\begin{array}{l}\text { Deploy sinker bars. Round trip wash barrel at } 1497.0 \text { mbsf. Drop fresh } \\
\text { core barrel. }\end{array}$ & 2345 & 4 May & 2.00 & 0.08 & 429.25 & 17.89 & \\
\hline $\begin{array}{l}\text { RCB Cores } 235 \mathrm{R}-236 \mathrm{R}(1507.1-1516.5 \mathrm{mbsf}) \text {, employing half-cores } \\
\text { with no liners to improve recovery. All cores obtained with } \\
\text { nonmagnetic core barrels. }\end{array}$ & 145 & 5 May & 15.25 & 0.64 & 444.50 & 18.52 & First 335 core! 235R (7\%); 236R (13\%). \\
\hline $\begin{array}{l}\text { Attempt to cut Core } 237 \mathrm{R}(1516.5-1518.2 \mathrm{mbsf}) ; \text { max overpull }= \\
60,000 \mathrm{lb} \text {, top drive max current }=800 \mathrm{~A}, \mathrm{WOB}=0 \text {. }\end{array}$ & 1700 & 5 May & 3.50 & 0.15 & 448.00 & 18.67 & \\
\hline $\begin{array}{l}\text { RIH coring line and retrieve Core 237R (1516.5-1518.2 mbsf). Circulate } \\
50 \text { and } 100 \text { bbl hi-vis gel sweeps at } 1518.2 \mathrm{mbsf} \text {. }\end{array}$ & 2030 & 5 May & 1.25 & 0.05 & 449.25 & 18.72 & 237R (empty). \\
\hline $\begin{array}{l}\text { Drop core barrel and attempt to cut Core } 238 \mathrm{R}(1518.2-1520.2 \mathrm{mbsf} \\
\text { tidal }= \pm 0.8 \mathrm{~m}) . \text { Pump } 50 \text { bbl hi-vis sweep at } 1520.2 \mathrm{mbsf} \text {. Average } \\
\text { ROP for May } 5=0.7 \mathrm{~m} / \mathrm{h} \text {. }\end{array}$ & 2145 & 5 May & 14.25 & 0.59 & 463.50 & 19.31 & \\
\hline $\mathrm{RIH}$ sinker bars and recover core barrel containing $20 \mathrm{~cm}$ roller. & 1200 & 6 May & 1.50 & 0.06 & 465.00 & 19.38 & 238R. \\
\hline $\begin{array}{l}\text { Drop bit deplugger. Core catcher sub was } \sim 0.5 \text { inch abraded, indicating } \\
\text { downhole mechanical problem. }\end{array}$ & 1330 & 6 May & 0.50 & 0.02 & 465.50 & 19.40 & \\
\hline $\begin{array}{l}\text { RIH sinker bars and recover deplugger. Lay out same. Pump } 70 \text { bbl of } \\
10.5 \text { ppg mud. }\end{array}$ & 1400 & 6 May & 1.25 & 0.05 & 466.75 & 19.45 & \\
\hline Rack top drive. & 1515 & 6 May & 1.50 & 0.06 & 468.25 & 19.51 & \\
\hline Pull back in hole with drill string to 58.2 mbsf. & 1645 & 6 May & 3.75 & 0.16 & 472.00 & 19.67 & \\
\hline Flush drill string with seawater to clean reentry cone of cuttings. & 2030 & 6 May & 0.50 & 0.02 & 472.50 & 19.69 & \\
\hline $\begin{array}{l}\text { POOH DP to the surface. Clear seafloor at } 2115 \mathrm{~h} \text {. Clear rotary table at } \\
0545 \mathrm{~h} \text {. Bit body honed to a smooth profile at bottom and sides. Bit } \\
\text { missing all } 4 \text { cones, } 4 \text { legs, and core guides. Bit spiral stabilizer blades } \\
\text { and embedded TCl inserts absent. Bit totally unrecognizable. }\end{array}$ & 2100 & 6 May & 8.75 & 0.36 & 481.25 & 20.05 & Clear seafloor at $2115 \mathrm{~h}$. End Run 9 at 0545 h. Bit disintegrated. \\
\hline $\begin{array}{l}\text { Prepare and make up Bowen } 9 \text { inch fishing magnet with } 2 \text { boot baskets } \\
\text { to } 2 \text { stands of DC; RIH to } 147 \text { mbrf. }\end{array}$ & 545 & 7 May & 3.00 & 0.13 & 484.25 & 20.18 & Start Run 10: Bowen 9 inch fishing magnet plus two junk baskets. \\
\hline Service rig. & 845 & 7 May & 0.50 & 0.02 & 484.75 & 20.20 & \\
\hline Resume RIH 147-2680 mbrf. & 915 & 7 May & 5.00 & 0.21 & 489.75 & 20.41 & \\
\hline Install VIT. & 1415 & 7 May & 0.50 & 0.02 & 490.25 & 20.43 & \\
\hline Resume RIH drill string 2680-3632 mbrf. & 1445 & 7 May & 1.75 & 0.07 & 492.00 & 20.50 & \\
\hline $\begin{array}{l}\text { Search and position vessel for reentry. Observe reentry cone clouded } \\
\text { over with mud. Attempt reentry, miss cone, and pull back. Break } \\
\text { circulation and reenter (Reentry 10) at } 1815 \mathrm{~h} \text {. }\end{array}$ & 1630 & 7 May & 1.75 & 0.07 & 493.75 & 20.57 & Reentry 10. \\
\hline RIH drill string to 580.1 mbsf. & 1815 & 7 May & 1.25 & 0.05 & 495.00 & 20.63 & \\
\hline Recover VIT. & 1930 & 7 May & 0.50 & 0.02 & 495.50 & 20.65 & \\
\hline RIH DP 580.1-1294.6 mbsf. Contact ledge that takes $10,000 \mathrm{lb}$. & 2000 & 7 May & 2.25 & 0.09 & 497.75 & 20.74 & \\
\hline Pick up top drive. & 2215 & 7 May & 0.50 & 0.02 & 498.25 & 20.76 & \\
\hline
\end{tabular}




\begin{tabular}{|c|c|c|c|c|c|c|c|}
\hline \multirow[b]{3}{*}{ Operation } & \multicolumn{2}{|c|}{ Start } & \multicolumn{4}{|c|}{ Expedition (from departure time) } & \multirow[b]{3}{*}{ Comments } \\
\hline & \multirow{2}{*}{$\begin{array}{l}\text { Local } \\
\text { time (h) }\end{array}$} & \multirow{2}{*}{$\begin{array}{l}\text { Date } \\
(2011)\end{array}$} & \multicolumn{2}{|c|}{ Duration } & \multicolumn{2}{|c|}{ Time (cumulative) } & \\
\hline & & & $\mathrm{h}$ & day & $\mathrm{h}$ & day & \\
\hline $\begin{array}{l}\text { RIH top drive } 1328.7-1434.2 \text { mbsf. Tight hole at } 1328.7 \text { mbsf takes } \\
10,000 \mathrm{lb} \text {. Excessive rotary current at } 20 \text { spm. Note increase in pump } \\
\text { pressure ( } 2500 \text { psi at } 20 \text { spm). Bleed off pressure at rig floor. }\end{array}$ & 2245 & 7 May & 3.00 & 0.13 & 501.25 & 20.89 & \\
\hline $\begin{array}{l}\text { Pull back in hole } 1434.2-1395.8 \mathrm{mbsf} \text { and attempt to unplug drill string } \\
\text { with high pressure. No joy. }\end{array}$ & 145 & 8 May & 1.25 & 0.05 & 502.50 & 20.94 & \\
\hline Pull back in hole 1395.8-1242.3 mbsf with top drive. & 300 & 8 May & 1.50 & 0.06 & 504.00 & 21.00 & \\
\hline Rack top drive. & 430 & 8 May & 0.50 & 0.02 & 504.50 & 21.02 & \\
\hline Pull back in hole $1242.3-264.2 \mathrm{mbsf}$ to just inside casing shoe. & 500 & 8 May & 2.00 & 0.08 & 506.50 & 21.10 & \\
\hline Attempt to circulate with circulating head. No joy. & 700 & 8 May & 0.25 & 0.01 & 506.75 & 21.11 & \\
\hline $\begin{array}{l}\text { POOH from } 264.2 \text { mbsf, clear seafloor at } 0755 \mathrm{~h} \text {. Recover drill string and } \\
\text { set back } 2 \text { stands of DC. Find } 4 \mathrm{~m} \text { of fine cuttings plugging inside of bit } \\
\text { sub and the } 2 \text { junk baskets. Clean out same. Lay out magnet, which is } \\
\text { at the rotary table at } 1555 \mathrm{~h} \text {. }\end{array}$ & 715 & 8 May & 8.75 & 0.36 & 515.50 & 21.48 & $\begin{array}{l}\text { Clear seafloor at } 0755 \mathrm{~h} \text {. End Run } 10 \text { at } 1555 \mathrm{~h} \text {. Bit sub and junk } \\
\text { basket filled with cuttings. Samples Run10-DC, Run10-EXJB, and } \\
\text { Run10-FM. }\end{array}$ \\
\hline $\begin{array}{l}\text { Make up Atlas tricone bit to dual set of junk baskets with } 3 \text { DC stands } \\
\text { and deploy to } 2704 \text { mbrf. }\end{array}$ & 1600 & 8 May & 8.00 & 0.33 & 523.50 & 21.81 & Start Run 11: Atlas tricone bit plus junk baskets. \\
\hline Launch VIT. & 000 & 9 May & 1.00 & 0.04 & 524.50 & 21.85 & \\
\hline Continue RIH DP 2704-3637 mbrf. Fill every 10 stands. & 100 & 9 May & 2.00 & 0.08 & 526.50 & 21.94 & \\
\hline Space out and reenter Hole 1256D at $0315 \mathrm{~h}$ (Run 11). & 300 & 9 May & 0.25 & 0.01 & 526.75 & 21.95 & Reentry 11. \\
\hline Continue RIH to $461.2 \mathrm{mbsf}$. & 315 & 9 May & 1.00 & 0.04 & 527.75 & 21.99 & \\
\hline Recover VIT. & 415 & 9 May & 0.50 & 0.02 & 528.25 & 22.01 & \\
\hline $\begin{array}{l}\text { Resume RIH } 461.2-1356.1 \mathrm{mbsf} \text { where bit contacts ledge. Pull back to } \\
1324.3 \text { mbsf. }\end{array}$ & 445 & 9 May & 2.50 & 0.10 & 530.75 & 22.11 & \\
\hline Pick up top drive and obtain SCR parameters. & 715 & 9 May & 0.50 & 0.02 & 531.25 & 22.14 & \\
\hline Clean up ledge at $1356.1 \mathrm{mbsf}$ and continue in hole to $1442.5 \mathrm{mbsf}$. & 745 & 9 May & 1.50 & 0.06 & 532.75 & 22.20 & \\
\hline Circulate 100 bbl hi-vis gel sweep at 1442.5 mbsf. & 915 & 9 May & 0.75 & 0.03 & 533.50 & 22.23 & \\
\hline $\begin{array}{l}\text { RIH } 1442.5-1520.3 \text { mbsf. Clean up undergauge areas of hole with top } \\
\text { drive max current }=500 \mathrm{~A} \text {. }\end{array}$ & 1000 & 9 May & 1.50 & 0.06 & 535.00 & 22.29 & \\
\hline Circulate 100 bbl hi-vis gel sweep at 1520.3 mbsf. & 1130 & 9 May & 0.50 & 0.02 & 535.50 & 22.31 & \\
\hline $\begin{array}{l}\text { Continue to circulate hole clean and work rathole at } 1520.3 \text { mbsf. } \\
\text { Circulate } 100 \text { bbl hi-vis gel sweep and circulate seawater ( } 3 \times \text { volume of } \\
\text { annulus). }\end{array}$ & 1200 & 9 May & 4.25 & 0.18 & 539.75 & 22.49 & \\
\hline Pull back in hole with top drive $1520.3-1363.0$ mbsf. & 1615 & 9 May & 1.50 & 0.06 & 541.25 & 22.55 & \\
\hline $\begin{array}{l}\text { RIH with top drive and tag ledge at } 1473 \text { mbsf. Work though ledge with } \\
\text { pumps and rotation. Observe excess pump pressure and torque off } \\
\text { slips at } 1477.5 \text { mbsf. Unable to pump. Reestablish rotation and } \\
\text { circulation. }\end{array}$ & 1745 & 9 May & 1.75 & 0.07 & 543.00 & 22.62 & \\
\hline $\begin{array}{l}\text { Work pipe } 1477.5-1459.0 \text { mbsf. Clear excess pump pressure and } \\
\text { torque. Top drive max current }=700 \mathrm{~A} ; \text { max pump pressure }=3000 \\
\text { psi. }\end{array}$ & 1930 & 9 May & 0.75 & 0.03 & 543.75 & 22.66 & \\
\hline $\begin{array}{l}\text { RIH with top drive and ream } 1477.6-1484.6 \text { mbsf. Continue to RIH with } \\
\text { top drive to } 1518.2 \text { mbsf. }\end{array}$ & 2015 & 9 May & 2.50 & 0.10 & 546.25 & 22.76 & \\
\hline Pump $150 \mathrm{bbl}$ gel sweep at $1518.2 \mathrm{mbsf}$. & 2245 & 9 May & 2.25 & 0.09 & 548.50 & 22.85 & \\
\hline Pull back in hole with top drive $1518.2-1324.6$ mbsf. & 100 & 10 May & 1.50 & 0.06 & 550.00 & 22.92 & \\
\hline Set back top drive. & 230 & 10 May & 0.50 & 0.02 & 550.50 & 22.94 & \\
\hline Resume pulling back in hole $1324.6-78.2$ mbsf. & 300 & 10 May & 2.50 & 0.10 & 553.00 & 23.04 & \\
\hline Flush top of cone with seawater. & 530 & 10 May & 0.25 & 0.01 & 553.25 & 23.05 & \\
\hline $\begin{array}{l}\mathrm{POOH} \text { drill string from } 78.2 \mathrm{mbsf} \text {. Clear seafloor at } 0605 \mathrm{~h} \text {. Bit at rotary } \\
\text { table at } 1130 \mathrm{~h} \text {. }\end{array}$ & 545 & 10 May & 5.75 & 0.24 & 559.00 & 23.29 & Clear seafloor at $0605 \mathrm{~h}$. End Run 11 at $1130 \mathrm{~h}$. \\
\hline Empty junk baskets and lay out tricone. & 1130 & 10 May & 0.75 & 0.03 & 559.75 & 23.32 & Nice cuttings in junk baskets. Samples Run11-EXJB. \\
\hline $\begin{array}{l}\text { Make up Bowen reverse circulating junk basket, } 1 \text { junk basket, and } 2 \text { DC } \\
\text { stands; RIH to } 2679 \text { mbrf. }\end{array}$ & 1215 & 10 May & 7.25 & 0.30 & 567.00 & 23.62 & Start Run 12: Bowen reverse circulation junk basket. \\
\hline
\end{tabular}




\begin{tabular}{|c|c|c|c|c|c|c|c|}
\hline \multirow[b]{3}{*}{ Operation } & \multicolumn{2}{|c|}{ Start } & \multicolumn{4}{|c|}{ Expedition (from departure time) } & \multirow[b]{3}{*}{ Comments } \\
\hline & \multirow{2}{*}{$\begin{array}{l}\text { Local } \\
\text { time (h) }\end{array}$} & \multirow{2}{*}{$\begin{array}{l}\text { Date } \\
(2011)\end{array}$} & \multicolumn{2}{|c|}{ Duration } & \multicolumn{2}{|c|}{ Time (cumulative) } & \\
\hline & & & $\mathrm{h}$ & day & $\mathrm{h}$ & day & \\
\hline Slip and cut $115 \mathrm{ft}$ of drilling line. & 1930 & 10 May & 1.50 & 0.06 & 568.50 & 23.69 & \\
\hline Install VIT. & 2100 & 10 May & 0.75 & 0.03 & 569.25 & 23.72 & \\
\hline Resume RIH drill string 2679-3640 mbrf. & 2145 & 10 May & 1.50 & 0.06 & 570.75 & 23.78 & \\
\hline Search and position vessel. Reenter Hole 1256D at $2330 \mathrm{~h}$ (Reentry 12). & 2315 & 10 May & 0.08 & 0.00 & 570.83 & 23.78 & Reentry 12. \\
\hline RIH to 808.7 mbsf. & 2320 & 10 May & 1.67 & 0.07 & 572.50 & 23.85 & \\
\hline Recover VIT. & 100 & 11 May & 0.50 & 0.02 & 573.00 & 23.87 & \\
\hline Resume RIH 808.7-1327.5 mbsf. & 130 & 11 May & 1.00 & 0.04 & 574.00 & 23.92 & \\
\hline Pick up top drive. & 230 & 11 May & 0.50 & 0.02 & 574.50 & 23.94 & \\
\hline Obtain SCR parameters and RIH 1327.5-1517.9 mbsf. & 300 & 11 May & 3.50 & 0.15 & 578.00 & 24.08 & \\
\hline Clean hole. Circulate at $150 \mathrm{spm}$ with $1600 \mathrm{psi}$. Find $2.5 \mathrm{~m}$ of fill. & 630 & 11 May & 2.00 & 0.08 & 580.00 & 24.17 & \\
\hline $\begin{array}{l}\text { Pump } 100 \text { bbl hi-vis sweep and chase with seawater ( } 1.5 x \text { drill string } \\
\text { volume). }\end{array}$ & 830 & 11 May & 1.00 & 0.04 & 581.00 & 24.21 & \\
\hline $\begin{array}{l}\text { Drop stainless steel ball at } 0937 \mathrm{~h} \text { and activate reverse circulation in } \\
\text { Bowen junk basket. }\end{array}$ & 930 & 11 May & 0.50 & 0.02 & 581.50 & 24.23 & $\mathrm{RCJB}$. \\
\hline Attempt to drill over junk at the bottom of the hole. & 1000 & 11 May & 0.50 & 0.02 & 582.00 & 24.25 & \\
\hline Pull back in hole 1516.1-1328.6 mbsf. & 1030 & 11 May & 1.50 & 0.06 & 583.50 & 24.31 & \\
\hline Rack top drive. & 1200 & 11 May & 0.50 & 0.02 & 584.00 & 24.33 & \\
\hline $\mathrm{POOH} 1328.6-58.9 \mathrm{mbrf}$. Clear top of cone at $1520 \mathrm{~h}$. & 1230 & 11 May & 9.00 & 0.38 & 593.00 & 24.71 & $\begin{array}{l}\text { Clear seafloor at } 1520 \mathrm{~h} \text {. End Run } 12 \text { at } 2200 \mathrm{~h} \text {. Samples Run12-DC, } \\
\text { Run12-EXJB, Run12-RCJB. }\end{array}$ \\
\hline $\begin{array}{l}\text { Find BHA DC up to tapered DC filled with fine cuttings }(50 \mathrm{~m}) \text { weighing } \\
\text { several hundred } \mathrm{kg} \text {. Individually clear each DC and provide contents to } \\
\text { scientists. Coarser gravel found in the head, crossover, and bit subs. } \\
\text { Empty and clean out the Bowen tool containing } \sim 20 \mathrm{~kg} \text { of granoblastic } \\
\text { dike rocks. }\end{array}$ & 2130 & 11 May & 8.00 & 0.33 & 601.00 & 25.04 & Big rock samples, no cone. \\
\hline Service rig. & 530 & 12 May & 0.50 & 0.02 & 601.50 & 25.06 & \\
\hline $\begin{array}{l}\text { Make up Bowen tool with single junk basket and } 2 \text { DC stands; RIH to } \\
2678 \text { mbrf. }\end{array}$ & 600 & 12 May & 5.50 & 0.23 & 607.00 & 25.29 & Start Run 13: Bowen RCJB. \\
\hline Launch VIT. & 1130 & 12 May & 0.50 & 0.02 & 607.50 & 25.31 & \\
\hline Resume RIH 2678-3631 mbrf. & 1200 & 12 May & 1.25 & 0.05 & 608.75 & 25.36 & \\
\hline Search and position vessel. Reenter Hole 1256D at $1335 \mathrm{~h}$. & 1315 & 12 May & 0.25 & 0.01 & 609.00 & 25.37 & Reentry 13. \\
\hline RIH DP to 664.8 mbsf. & 1330 & 12 May & 1.50 & 0.06 & 610.50 & 25.44 & \\
\hline Recover VIT. & 1500 & 12 May & 0.50 & 0.02 & 611.00 & 25.46 & \\
\hline Resume RIH 664.8-1384.8 mbsf. & 1530 & 12 May & 1.50 & 0.06 & 612.50 & 25.52 & \\
\hline Pick up top drive. & 1700 & 12 May & 0.50 & 0.02 & 613.00 & 25.54 & \\
\hline $\begin{array}{l}\text { RIH with top drive and rotation and circulation past a soft tag at } 1465.0 \\
\text { mbsf and a hard tag at } 1518.0 \text { mbsf. Backflow on connections starting } \\
\text { at } 1470.0 \text { mbsf. }\end{array}$ & 1730 & 12 May & 2.75 & 0.11 & 615.75 & 25.66 & \\
\hline $\begin{array}{l}\text { Work drill string to } 1518.0 \mathrm{mbsf} \text { and fail in an attempt to penetrate to } \\
1520.2 \mathrm{mbsf} \text { with } \max \mathrm{WOB}=2000-4000 \mathrm{lb} \text { and } 160 \mathrm{spm} \text { at } 1600 \\
\text { psi. Top drive current }=200-400 \mathrm{~A} \text {. Circulate } 100 \mathrm{bbl} \text { hi-vis sweep. } \\
\text { Chase same with seawater ( } 2 \times \text { drill string volume). }\end{array}$ & 2015 & 12 May & 2.00 & 0.08 & 617.75 & 25.74 & \\
\hline $\begin{array}{l}\text { Drop stainless steel ball to activate reverse circulation. Unable to shear } \\
\text { pins in tool with pump pressure as high as } 3000 \mathrm{psi} \text { at } 50 \mathrm{spm} \text {. }\end{array}$ & 2215 & 12 May & 0.75 & 0.03 & 618.50 & 25.77 & \\
\hline Pull back in hole with top drive to 1327.3 mbsf. & 2300 & 12 May & 1.75 & 0.07 & 620.25 & 25.84 & \\
\hline Rack top drive. & 045 & 13 May & 0.50 & 0.02 & 620.75 & 25.86 & \\
\hline $\begin{array}{l}\text { POOH from } 1327.3 \mathrm{mbsf} \text { and clear seafloor at } 0340 \mathrm{~h} \text {. Bowen junk } \\
\text { basket at rotary table at } 1100 \mathrm{~h} \text {. Basket contains granoblastic dike } \\
\text { rocks as large as } 3.4 \mathrm{~kg} \text {. Apparently the Bowen tool was activated by } \\
\text { the stainless steel ball. The loss of circulation was probably due to } \\
\text { clogged jets. Almost the entire BHA was filled with fine cuttings again. }\end{array}$ & 115 & 13 May & 9.75 & 0.41 & 630.50 & 26.27 & $\begin{array}{l}\text { Clear seafloor at } 0340 \mathrm{~h} \text {. End Run } 13 \text { at } 1100 \mathrm{~h} \text {. Samples Run13-DC, } \\
\text { Run13-EXJB, Run13-RCJB. }\end{array}$ \\
\hline
\end{tabular}




\begin{tabular}{|c|c|c|c|c|c|c|c|}
\hline \multirow[b]{3}{*}{ Operation } & \multicolumn{2}{|c|}{ Start } & \multicolumn{4}{|c|}{ Expedition (from departure time) } & \multirow[b]{3}{*}{ Comments } \\
\hline & \multirow{2}{*}{$\begin{array}{l}\text { Local } \\
\text { time }(h)\end{array}$} & \multirow{2}{*}{$\begin{array}{l}\text { Date } \\
(2011)\end{array}$} & \multicolumn{2}{|c|}{ Duration } & \multicolumn{2}{|c|}{ Time (cumulative) } & \\
\hline & & & $\mathrm{h}$ & day & $\mathrm{h}$ & day & \\
\hline $\begin{array}{l}\text { Dismantle Bowen reverse circulating junk basket and clean all } \\
\text { components and service. }\end{array}$ & 1100 & 13 May & 1.75 & 0.07 & 632.25 & 26.34 & \\
\hline $\begin{array}{l}\text { Lay down Bowen tool and pick up Homco } 9.75 \text { inch flow-though junk } \\
\text { basket with bit sub junk basket and float, } 2 \text {-stand BHA, and boot } \\
\text { basket. Lay out } 1 \text { joint of 5-1/2 inch of transition pipe. RIH to } 2670 \\
\text { mbrf. }\end{array}$ & 1245 & 13 May & 7.75 & 0.32 & 640.00 & 26.67 & $\begin{array}{l}\text { Start Run 14: Homco } 9.75 \text { inch flow-though junk basket with bit sub } \\
\text { junk basket and float. }\end{array}$ \\
\hline Deploy VIT. & 2030 & 13 May & 0.75 & 0.03 & 640.75 & 26.70 & \\
\hline RIH DP 2670-3631 mbrf. & 2115 & 13 May & 1.75 & 0.07 & 642.50 & 26.77 & \\
\hline Search and position vessel. Reenter Hole 1256D at $2315 \mathrm{~h}$ (Reentry 14). & 2300 & 13 May & 0.25 & 0.01 & 642.75 & 26.78 & Reentry 14. \\
\hline RIH drill string to 512.1 mbsf. & 2315 & 13 May & 1.50 & 0.06 & 644.25 & 26.84 & \\
\hline Recover VIT. & 045 & 14 May & 2.25 & 0.09 & 646.50 & 26.94 & \\
\hline Resume RIH 512.1-1404.3 mbsf. & 300 & 14 May & 0.50 & 0.02 & 647.00 & 26.96 & \\
\hline Continue RIH 1404.3-1517.2 mbsf. & 330 & 14 May & 2.25 & 0.09 & 649.25 & 27.05 & \\
\hline $\begin{array}{l}\text { Pump } 100 \mathrm{bbl} \text { sweep and continue to work down to top of fish at } \\
1521.0 \mathrm{mbsf} \text {. }\end{array}$ & 545 & 14 May & 2.50 & 0.10 & 651.75 & 27.16 & \\
\hline Attempt to recover junk/fish. & 815 & 14 May & 0.50 & 0.02 & 652.25 & 27.18 & \\
\hline Circulate $50 \mathrm{bbl} \mathrm{sweep} \mathrm{at} 1520.0$ mbsf. & 845 & 14 May & 1.00 & 0.04 & 653.25 & 27.22 & \\
\hline Pull back in hole with top drive $1519.2-1404.6$ mbsf. & 945 & 14 May & 0.75 & 0.03 & 654.00 & 27.25 & \\
\hline Rack top drive. & 1030 & 14 May & 0.50 & 0.02 & 654.50 & 27.27 & \\
\hline $\begin{array}{l}\text { POOH with drill string and clear seafloor at } 1345 \mathrm{~h} \text {. Rack back DC in } \\
\text { derrick. Homco FTJB clears rotary at } 2010 \mathrm{~h} \text {. }\end{array}$ & 1100 & 14 May & 9.25 & 0.39 & 663.75 & 27.66 & $\begin{array}{l}\text { Clear seafloor at } 1345 \text { h. End Run } 14 \text { at } 2010 \text { h. Samples Run14- } \\
\text { EXJB, BSJB, FTJB. }\end{array}$ \\
\hline $\begin{array}{l}\text { Empty FTJB of } 2 \text { rocks (combined weight }=3.2 \mathrm{~kg} \text { ). Lower set of junk } \\
\text { catcher fingers completely torn out. }\end{array}$ & 2015 & 14 May & 0.75 & 0.03 & 664.50 & 27.69 & \\
\hline $\begin{array}{l}\text { Make up new Smith hard formation 9-7/8 inch tricone bit with single } \\
\text { junk basket to 3-stand BHA and RIH to } 84 \text { mbrf. }\end{array}$ & 2100 & 14 May & 1.25 & 0.05 & 665.75 & 27.74 & $\begin{array}{l}\text { Start Run 15: Smith hard formation 9-7/8 inch tricone bit with single } \\
\text { junk basket. }\end{array}$ \\
\hline Slip and cut $115 \mathrm{ft}$ of drilling line. & 2215 & 14 May & 1.50 & 0.06 & 667.25 & 27.80 & \\
\hline RIH with $5-1 / 2$ inch transition pipe to 132.9 mbrf. & 2345 & 14 May & 0.25 & 0.01 & 667.50 & 27.81 & \\
\hline Service rig. & 000 & 15 May & 0.50 & 0.02 & 668.00 & 27.83 & \\
\hline $\begin{array}{l}\text { Resume RIH 5-1/2 inch transition pipe 133-2694 mbrf, filling every } 10 \\
\text { stands. }\end{array}$ & 030 & 15 May & 4.50 & 0.19 & 672.50 & 28.02 & \\
\hline Deploy VIT. & 500 & 15 May & 0.50 & 0.02 & 673.00 & 28.04 & \\
\hline $\begin{array}{l}\text { Resume RIH } 2694-3924 \mathrm{mbrf} \text {. Reenter Hole 1256D (Reentry 15) at } 0730 \\
\mathrm{~h} \text { and RIH to } 278.5 \mathrm{mbsf}\end{array}$ & 530 & 15 May & 3.00 & 0.13 & 676.00 & 28.17 & Reentry 15. \\
\hline Recover VIT. & 830 & 15 May & 0.50 & 0.02 & 676.50 & 28.19 & \\
\hline RIH 278.5-1371.8 mbsf. & 900 & 15 May & 3.25 & 0.14 & 679.75 & 28.32 & \\
\hline Pick up top drive. & 1215 & 15 May & 0.50 & 0.02 & 680.25 & 28.34 & \\
\hline $\begin{array}{l}\text { Resume RIH from } 1371.8 \mathrm{mbsf} \text {. Tag soft fill at } 1510.0 \mathrm{mbsf} \text { and hard tag } \\
\text { at } 1518.8 \mathrm{mbsf} \text {. }\end{array}$ & 1245 & 15 May & 1.50 & 0.06 & 681.75 & 28.41 & \\
\hline $\begin{array}{l}\text { Pick up } 30 \mathrm{ft} \text { knobby and work bit with light WOB at } 1518.5 \mathrm{mbsf} \text { and } \\
\text { then down to } 1520.6 \text { mbsf multiple times, attempting to stabilize the } \\
\text { bottom } 2-3 \mathrm{~m} \text { of the hole. Hole packs off below } 1518.0 \text { mbsf and } \\
\text { requires working back to bottom. Circulate multiple mud sweeps at } \\
1520.6 \mathrm{mbsf} \text { (total }=400 \mathrm{bbl} \text { ). Continue to work drill string } 1518.5- \\
1521.05 \mathrm{mbsf} \text {. Pump } 200 \mathrm{bbl} \text { of sweeps. Pull drill string to inspect and } \\
\text { change the bit. }\end{array}$ & 1415 & 15 May & 16.00 & 0.67 & 697.75 & 29.07 & \\
\hline Pull back in hole with top drive $1515.5-1410.1$ mbsf. & 615 & 16 May & 1.25 & 0.05 & 699.00 & 29.12 & \\
\hline Rack top drive. & 730 & 16 May & 0.50 & 0.02 & 699.50 & 29.15 & \\
\hline
\end{tabular}




\begin{tabular}{|c|c|c|c|c|c|c|c|}
\hline \multirow[b]{3}{*}{ Operation } & \multicolumn{2}{|c|}{ Start } & \multicolumn{4}{|c|}{ Expedition (from departure time) } & \multirow[b]{3}{*}{ Comments } \\
\hline & \multirow{2}{*}{$\begin{array}{l}\text { Local } \\
\text { time }(h)\end{array}$} & \multirow{2}{*}{$\begin{array}{l}\text { Date } \\
(2011)\end{array}$} & \multicolumn{2}{|c|}{ Duration } & \multicolumn{2}{|c|}{ Time (cumulative) } & \\
\hline & & & $\mathrm{h}$ & day & $\mathrm{h}$ & day & \\
\hline $\begin{array}{l}\text { POOH drill string and clear seafloor at } 1015 \mathrm{~h} \text {. Rack back } 3 \text { stands. Bit } \\
\text { clears rotary table at } 1545 \mathrm{~h} \text {. Inspect bit and find bearings still tight } \\
\text { with virtually no wear on teeth except for a single chipped tooth on } \\
\text { the heel. Bit is under gauge by } 0.4 \text { inches with some shirttail wear and } \\
\text { minor junk damage on body. }\end{array}$ & 800 & 16 May & 7.75 & 0.32 & 707.25 & 29.47 & $\begin{array}{l}\text { Clear seafloor at } 1015 \mathrm{~h} \text {. End Run } 15 \text { at } 1545 \mathrm{~h} \text {. Samples Run15- } \\
\text { EXJB. }\end{array}$ \\
\hline Clean out junk basket. & 1545 & 16 May & 0.50 & 0.02 & 707.75 & 29.49 & \\
\hline $\begin{array}{l}\text { Make up new 9-7/8 inch Smith FH3VPS tricone to a 3-stand BHA; RIH to } \\
2693 \text { mbrf. }\end{array}$ & 1615 & 16 May & 7.75 & 0.32 & 715.50 & 29.81 & Start Run 16: 9-7/8 inch Smith FH3VPS tricone bit. \\
\hline Deploy VIT. & 000 & 17 May & 0.50 & 0.02 & 716.00 & 29.83 & \\
\hline Resume RIH 2693-3644 mbrf. & 030 & 17 May & 2.00 & 0.08 & 718.00 & 29.92 & \\
\hline Space out to reenter. Reenter Hole 1256D at 0245 h (Reentry 16). & 230 & 17 May & 0.25 & 0.01 & 718.25 & 29.93 & Reentry 16. \\
\hline Resume RIH to 507.2 mbsf. Fill pipe every 10 stands. & 245 & 17 May & 1.25 & 0.05 & 719.50 & 29.98 & \\
\hline Recover VIT. & 400 & 17 May & 0.50 & 0.02 & 720.00 & 30.00 & \\
\hline Continue RIH 507.2-1399.7 mbsf. & 430 & 17 May & 2.00 & 0.08 & 722.00 & 30.08 & \\
\hline Pick up top drive. & 630 & 17 May & 0.50 & 0.02 & 722.50 & 30.10 & \\
\hline RIH 1399.7-1516.5 mbsf. & 700 & 17 May & 1.25 & 0.05 & 723.75 & 30.16 & \\
\hline $\begin{array}{l}\text { Wash/ream } 1516.5-1519.7 \text { mbsf. Circulate } 60 \mathrm{bbl} \text { sweep at } 1516.7 \\
\text { mbsf. Flush hole with } 200 \mathrm{bbl} \text { mud at } 1519.6 \mathrm{mbsf} \text {. }\end{array}$ & 815 & 17 May & 16.00 & 0.67 & 739.75 & 30.82 & \\
\hline Pull back in hole with top drive $1519.6-1399.7$ mbsf. & 015 & 18 May & 0.75 & 0.03 & 740.50 & 30.85 & \\
\hline Rack top drive. & 100 & 18 May & 0.50 & 0.02 & 741.00 & 30.87 & \\
\hline $\begin{array}{l}\text { POOH drill string. Clear seafloor at } 0340 \mathrm{~h} \text {. Bit at rotary table at } 0900 \mathrm{~h} \text {. } \\
\text { Lay out used tricone bit (in gauge) and minus } 6 \text { teeth on one cone. }\end{array}$ & 130 & 18 May & 7.50 & 0.31 & 748.50 & 31.19 & Clear seafloor at $0340 \mathrm{~h}$. End Run 16 at $0900 \mathrm{~h}$. \\
\hline $\begin{array}{l}\text { Make up 9-5/8 inch flat-bottomed mill with EXJB and } 3 \text {-stand BHA and } \\
\text { RIH to } 162 \text { mbrf. }\end{array}$ & 900 & 18 May & 1.50 & 0.06 & 750.00 & 31.25 & Start Run 17: 9-5/8 inch flat-bottomed mill with EXJB. \\
\hline Service rig. & 1030 & 18 May & 0.50 & 0.02 & 750.50 & 31.27 & \\
\hline Resume RIH 162-2695 mbrf. & 1100 & 18 May & 4.75 & 0.20 & 755.25 & 31.47 & \\
\hline Install VIT. & 1545 & 18 May & 0.50 & 0.02 & 755.75 & 31.49 & \\
\hline RIH 2695-3637 mbrf. & 1615 & 18 May & 2.50 & 0.10 & 758.25 & 31.59 & \\
\hline Search and position vessel. Reenter Hole 1256D at $1850 \mathrm{~h}$. & 1845 & 18 May & 0.25 & 0.01 & 758.50 & 31.60 & Reentry 17. \\
\hline RIH drill string to 480.5 mbsf. & 1900 & 18 May & 1.25 & 0.05 & 759.75 & 31.66 & \\
\hline Recover VIT. & 2015 & 18 May & 0.50 & 0.02 & 760.25 & 31.68 & \\
\hline Resume RIH 480.5-1429.9 mbsf. & 2045 & 18 May & 2.75 & 0.11 & 763.00 & 31.79 & \\
\hline Pick up top drive. & 2330 & 18 May & 0.50 & 0.02 & 763.50 & 31.81 & \\
\hline Continue RIH with top drive $1429.9-1520.0$ mbsf. & 000 & 19 May & 1.50 & 0.06 & 765.00 & 31.87 & \\
\hline $\begin{array}{l}\text { Mill debris at } 1520.0-1521.0 \text { mbsf. Use junk basket pump sweeps. Pump } \\
200 \text { bbl sweep at } 1520.0 \text { mbsf. }\end{array}$ & 130 & 19 May & 12.00 & 0.50 & 777.00 & 32.37 & \\
\hline $\begin{array}{l}\text { Circulate } 100 \text { bbl sweep and chase same with seawater ( } 2 \times \text { drill string } \\
\text { volume). }\end{array}$ & 1330 & 19 May & 1.25 & 0.05 & 778.25 & 32.43 & \\
\hline $\begin{array}{l}\text { Lay out } 30 \mathrm{ft} \text { knobby and pull back in hole with top drive to } 1429.9 \\
\text { mbsf. }\end{array}$ & 1445 & 19 May & 0.75 & 0.03 & 779.00 & 32.46 & \\
\hline Rack top drive. & 1530 & 19 May & 0.50 & 0.02 & 779.50 & 32.48 & \\
\hline $\begin{array}{l}\text { POOH and clear seafloor at } 1920 \mathrm{~h} \text {. Offset vessel } 50 \mathrm{~m} \text { west and } \\
\text { continue POOH to } 2354 \mathrm{mbrf} \text {. }\end{array}$ & 1600 & 19 May & 5.50 & 0.23 & 785.00 & 32.71 & Clear seafloor at $1920 \mathrm{~h}$. \\
\hline Slip and cut $115 \mathrm{ft}$ of drilling line. & 2130 & 19 May & 1.50 & 0.06 & 786.50 & 32.77 & \\
\hline Resume $\mathrm{POOH}$ to surface. Used mill at rotary table at $0315 \mathrm{~h}$. & 2300 & 19 May & 4.25 & 0.18 & 790.75 & 32.95 & End Run 17 at 0315 h. Samples Run17-BSJB. \\
\hline $\begin{array}{l}\text { Lay out mill. Clean and lay out damaged junk basket. Mill heavily worn } \\
\text { and under gauge by } \sim 0.5 \text { inches. Pick up new } 9 \text { inch flat mill with fresh } \\
\text { junk basket; RIH to } 162 \text { mbrf. }\end{array}$ & 315 & 20 May & 2.25 & 0.09 & 793.00 & 33.04 & Start Run 18: 9 inch flat mill with junk basket. \\
\hline Service rig. & 530 & 20 May & 1.00 & 0.04 & 794.00 & 33.08 & \\
\hline Resume RIH 162-2694 mbrf while filling every 10 stands. & 630 & 20 May & 5.00 & 0.21 & 799.00 & 33.29 & \\
\hline
\end{tabular}




\begin{tabular}{|c|c|c|c|c|c|c|c|}
\hline \multirow[b]{3}{*}{ Operation } & \multicolumn{2}{|c|}{ Start } & \multicolumn{4}{|c|}{ Expedition (from departure time) } & \multirow[b]{3}{*}{ Comments } \\
\hline & \multirow{2}{*}{$\begin{array}{l}\text { Local } \\
\text { time (h) }\end{array}$} & \multirow{2}{*}{$\begin{array}{l}\text { Date } \\
(2011)\end{array}$} & \multicolumn{2}{|c|}{ Duration } & \multicolumn{2}{|c|}{ Time (cumulative) } & \\
\hline & & & $\mathrm{h}$ & day & $\mathrm{h}$ & day & \\
\hline Launch VIT. & 1130 & 20 May & 0.50 & 0.02 & 799.50 & 33.31 & \\
\hline Resume RIH 2694-3637 mbrf. & 1200 & 20 May & 1.75 & 0.07 & 801.25 & 33.39 & \\
\hline Search and position vessel. Reenter Hole 1256D (Reentry 18) at $1415 \mathrm{~h}$. & 1345 & 20 May & 0.50 & 0.02 & 801.75 & 33.41 & Reentry 18. \\
\hline RIH drill string to 451.2 mbsf. & 1415 & 20 May & 1.25 & 0.05 & 803.00 & 33.46 & \\
\hline Recover VIT. & 1530 & 20 May & 0.50 & 0.02 & 803.50 & 33.48 & \\
\hline Resume RIH 451.2-1458.6 mbsf. & 1600 & 20 May & 2.25 & 0.09 & 805.75 & 33.57 & \\
\hline Pick up top drive. & 1815 & 20 May & 0.50 & 0.02 & 806.25 & 33.59 & \\
\hline $\begin{array}{l}\text { RIH with top drive; tag fill at } 1518.9 \text { mbsf. Advance with low pump and } \\
\text { rotary speed and tag hard fill at } 1520.4 \text { mbsf. }\end{array}$ & 1845 & 20 May & 1.00 & 0.04 & 807.25 & 33.64 & \\
\hline $\begin{array}{l}\text { Mill junk and work junk basket. Pump } 100 \text { bbl sepiolite sweep; pump } \\
120 \text { bbl sweep at } 1520.9 \text { mbsf. }\end{array}$ & 1945 & 20 May & 6.00 & 0.25 & 813.25 & 33.89 & \\
\hline Pump 100 bbl sepiolite sweep and circulate out. & 145 & 21 May & 1.25 & 0.05 & 814.50 & 33.94 & \\
\hline Pull back in hole with top drive $1520.9-1429.8$ mbsf. & 300 & 21 May & 1.00 & 0.04 & 815.50 & 33.98 & \\
\hline Rack top drive. & 400 & 21 May & 0.50 & 0.02 & 816.00 & 34.00 & \\
\hline $\begin{array}{l}\text { POOH from } 1520.9 \text { mbsf and clear seafloor at } 0645 \mathrm{~h} \text {; milling tool at } \\
\text { drill floor at } 1225 \mathrm{~h} \text {. The abrasive surface of the milling tool was } \\
\text { eroded, with some external junk damage on the side of the tool and } \\
\text { the crossover sub directly above the mill. }\end{array}$ & 430 & 21 May & 8.00 & 0.33 & 824.00 & 34.33 & Clear seafloor at $0645 \mathrm{~h}$. \\
\hline $\begin{array}{l}\text { Empty and clean out the external junk basket. In addition to the usual } \\
\text { rock fragments and fine cuttings, some flakes of what appears to be } \\
\text { freshly ground metal were also found. }\end{array}$ & 1230 & 21 May & 0.25 & 0.01 & 824.25 & 34.34 & End Run 18 at $1225 \mathrm{~h}$. Samples Run18-BSJB. \\
\hline $\begin{array}{l}\text { Make up RCJB with } 3 \text { EXJB and deploy along with a 2-stand BHA. RIH to } \\
2670 \text { mbrf. }\end{array}$ & 1245 & 21 May & 7.50 & 0.31 & 831.75 & 34.66 & Start Run 19: RCJB plus 3 EXJB. \\
\hline Install VIT. & 2015 & 21 May & 0.50 & 0.02 & 832.25 & 34.68 & \\
\hline RIH drill string to $3632 \mathrm{mbrf}$. & 2045 & 21 May & 1.50 & 0.06 & 833.75 & 34.74 & \\
\hline Search and position vessel. Reenter Hole 1256D (Run 19) at $2230 \mathrm{~h}$. & 2215 & 21 May & 0.25 & 0.01 & 834.00 & 34.75 & Reentry 19. \\
\hline RIH DP to 599.6 mbsf. & 2230 & 21 May & 1.25 & 0.05 & 835.25 & 34.80 & \\
\hline Recover VIT. & 2345 & 21 May & 0.50 & 0.02 & 835.75 & 34.82 & \\
\hline Continue RIH 599.6-1405.7 mbsf. & 015 & 22 May & 1.25 & 0.05 & 837.00 & 34.87 & \\
\hline Pick up top drive. & 130 & 22 May & 0.50 & 0.02 & 837.50 & 34.90 & \\
\hline RIH 1405.7-1519.5 mbsf. Hard tag at 1519.5 mbsf. & 200 & 22 May & 1.25 & 0.05 & 838.75 & 34.95 & \\
\hline Work junk baskets. & 315 & 22 May & 0.50 & 0.02 & 839.25 & 34.97 & \\
\hline $\begin{array}{l}\text { Pump } 100 \text { bbl sweep and chase same with seawater ( } 2 \times \text { annular } \\
\text { volume). Continue to work junk baskets. }\end{array}$ & 345 & 22 May & 2.00 & 0.08 & 841.25 & 35.05 & \\
\hline $\begin{array}{l}\text { Drop stainless steel ball in open pipe. Advance RCJB to } 1520.5 \text { mbsf with } \\
\text { slow rotation and light WOB. Jog rotation attempting to catch debris. }\end{array}$ & 545 & 22 May & 1.25 & 0.05 & 842.50 & 35.10 & \\
\hline Pull back in hole with top drive $1520.5-1434.4$ mbsf. & 700 & 22 May & 0.50 & 0.02 & 843.00 & 35.13 & \\
\hline Rack top drive. & 730 & 22 May & 0.50 & 0.02 & 843.50 & 35.15 & \\
\hline $\begin{array}{l}\mathrm{POOH} \text { with drill string and clear seafloor at } 1015 \mathrm{~h} \text {. Rack back BHA. RCJB } \\
\text { at rotary table at } 1645 \mathrm{~h} \text {. }\end{array}$ & 800 & 22 May & 8.75 & 0.36 & 852.25 & 35.51 & Clear seafloor at $1015 \mathrm{~h}$. \\
\hline $\begin{array}{l}\text { Empty RCJB of congealed sepiolite and } 4 \text { large rocks (total weight }=8.9 \\
\mathrm{~kg} \text {; largest rock }=3.9 \mathrm{~kg} \text { ). Unload } 3 \mathrm{EXJB} \text { of cuttings and a few small } \\
\text { metal fragments. }\end{array}$ & 1645 & 22 May & 1.25 & 0.05 & 853.50 & 35.56 & End Run 19 at 1645 h. Samples Run19-RCJB, BSJB, EXBJ. \\
\hline $\begin{array}{l}\text { Rebuild and make up RCJB and } 3 \text { EXJB with a 2-stand BHA and RIH to } \\
1793 \text { mbrf. }\end{array}$ & 1800 & 22 May & 6.00 & 0.25 & 859.50 & 35.81 & Start Run 20: RCJB plus 3 EXJB. \\
\hline Repair pneumatic supply lines for drawworks high clutch. & 000 & 23 May & 3.00 & 0.13 & 862.50 & 35.94 & \\
\hline Resume RIH 1793-2670 mbrf. & 300 & 23 May & 1.25 & 0.05 & 863.75 & 35.99 & \\
\hline Launch VIT. & 415 & 23 May & 0.50 & 0.02 & 864.25 & 36.01 & \\
\hline RIH 2670-3640 mbrf. & 445 & 23 May & 1.75 & 0.07 & 866.00 & 36.08 & \\
\hline Position vessel, space out, and reenter Hole $1256 \mathrm{D}$ at $0635 \mathrm{~h}$. & 630 & 23 May & 0.25 & 0.01 & 866.25 & 36.09 & Reentry 20. \\
\hline
\end{tabular}




\begin{tabular}{|c|c|c|c|c|c|c|c|}
\hline \multirow[b]{3}{*}{ Operation } & \multicolumn{2}{|c|}{ Start } & \multicolumn{4}{|c|}{ Expedition (from departure time) } & \multirow[b]{3}{*}{ Comments } \\
\hline & \multirow{2}{*}{$\begin{array}{l}\text { Local } \\
\text { time }(h)\end{array}$} & \multirow{2}{*}{$\begin{array}{l}\text { Date } \\
(2011)\end{array}$} & \multicolumn{2}{|c|}{ Duration } & \multicolumn{2}{|c|}{ Time (cumulative) } & \\
\hline & & & $\mathrm{h}$ & day & $\mathrm{h}$ & day & \\
\hline RIH to 513.5 mbsf. & 645 & 23 May & 0.75 & 0.03 & 867.00 & 36.13 & \\
\hline Recover VIT. & 730 & 23 May & 0.50 & 0.02 & 867.50 & 36.15 & \\
\hline Resume RIH 513.5-1462.9 mbsf. & 800 & 23 May & 1.25 & 0.05 & 868.75 & 36.20 & \\
\hline Pick up top drive. & 915 & 23 May & 0.50 & 0.02 & 869.25 & 36.22 & \\
\hline Continue RIH 1462.9-1519.0 mbsf. & 945 & 23 May & 0.75 & 0.03 & 870.00 & 36.25 & \\
\hline Hard tag at 1519.5 mbsf (tide adjusted). Work external junk baskets. & 1030 & 23 May & 0.25 & 0.01 & 870.25 & 36.26 & \\
\hline Pump 100 bbl sweep followed by seawater ( $2 \times$ annular volume). & 1045 & 23 May & 1.75 & 0.07 & 872.00 & 36.33 & \\
\hline $\begin{array}{l}\text { Drop stainless steel ball and activate RCJB. Note increase in pressure of } \\
600 \text { psi. Unable to pass hard tag at } 1519.0 \text { mbsf with max WOB }= \\
7000 \mathrm{lb} \text { and very slow rotation. }\end{array}$ & 1230 & 23 May & 0.75 & 0.03 & 872.75 & 36.36 & \\
\hline Pull back in hole with top drive to 1462.9 mbsf. & 1315 & 23 May & 0.75 & 0.03 & 873.50 & 36.40 & \\
\hline Rack top drive. & 1400 & 23 May & 0.50 & 0.02 & 874.00 & 36.42 & \\
\hline $\mathrm{POOH}$ with drill string to $3042 \mathrm{mbrf}$. Clear seafloor at $1725 \mathrm{~h}$. & 1430 & 23 May & 4.00 & 0.17 & 878.00 & 36.58 & Clear seafloor at $1725 \mathrm{~h}$. \\
\hline Slip and cut $115 \mathrm{ft}$ of drilling line. & 1830 & 23 May & 1.50 & 0.06 & 879.50 & 36.65 & \\
\hline Resume $\mathrm{POOH}$ from 3042 to surface. $\mathrm{RCJB}$ at the rotary table at $0215 \mathrm{~h}$. & 2000 & 23 May & 6.25 & 0.26 & 885.75 & 36.91 & \\
\hline $\begin{array}{l}\text { Lay out and empty RCJB and } 3 \mathrm{EXJB} \text {. RCJB contained } 3 \text { rocks (total } \\
\text { weight }=5.0 \mathrm{~kg} \text { ), one }(1.4 \mathrm{~kg}) \text { is gabbro. The angularity of the rocks } \\
\text { indicates fresh deposition with a suspected origin somewhere in the } \\
\text { bottommost } 7 \mathrm{~m} \text { of the hole. The external junk baskets contain gravel- } \\
\text { sized cuttings to small pebbles. }\end{array}$ & 215 & 24 May & 2.75 & 0.11 & 888.50 & 37.02 & End Run 20 at $0215 \mathrm{~h}$. Samples Run20-RCJB, BSJB, EXJB. \\
\hline Make up RCJB and 3 EXJB with 2-stand BHA; RIH to 131 mbrf. & 500 & 24 May & 0.75 & 0.03 & 889.25 & 37.05 & Start Run 21: RCJB plus 3 EXJB. \\
\hline Service rig. & 545 & 24 May & 0.50 & 0.02 & 889.75 & 37.07 & \\
\hline Continue RIH 131-2670 mbrf. & 615 & 24 May & 3.25 & 0.14 & 893.00 & 37.21 & \\
\hline Launch VIT. & 930 & 24 May & 0.50 & 0.02 & 893.50 & 37.23 & \\
\hline $\begin{array}{l}\text { Resume RIH 2670-3640.0 mbrf. Reenter Hole 1256D at } 1115 \text { h (Reentry } \\
\text { 21). }\end{array}$ & 1000 & 24 May & 1.25 & 0.05 & 894.75 & 37.28 & Reentry 21. \\
\hline Continue RIH to 340.9 mbsf. & 1115 & 24 May & 0.75 & 0.03 & 895.50 & 37.31 & \\
\hline Recover VIT. & 1200 & 24 May & 0.50 & 0.02 & 896.00 & 37.33 & \\
\hline Resume RIH 340.9-1434.4 mbsf. & 1230 & 24 May & 2.25 & 0.09 & 898.25 & 37.43 & \\
\hline Pick up top drive. & 1445 & 24 May & 0.50 & 0.02 & 898.75 & 37.45 & \\
\hline $\begin{array}{l}\text { RIH with top drive and minimum pump/rotation. Tag soft fill at } 1518.8 \\
\text { mbsf. }\end{array}$ & 1515 & 24 May & 1.00 & 0.04 & 899.75 & 37.49 & \\
\hline Wash to $1519.8 \mathrm{mbsf}$ and work junk baskets. & 1615 & 24 May & 0.25 & 0.01 & 900.00 & 37.50 & \\
\hline $\begin{array}{l}\text { Pump } 100 \mathrm{bbl} \text { of sepiolite sweep mud and chase with } 2 \times \text { annular volume } \\
\text { of seawater. }\end{array}$ & 1630 & 24 May & 1.50 & 0.06 & 901.50 & 37.56 & \\
\hline Drop stainless steel ball, activate RCJB, and work same. & 1800 & 24 May & 0.75 & 0.03 & 902.25 & 37.59 & \\
\hline $\begin{array}{l}\text { Displace lower portion of annulus with } 200 \mathrm{bbl} \text { of drill water in } \\
\text { preparation for logging. }\end{array}$ & 1845 & 24 May & 0.75 & 0.03 & 903.00 & 37.63 & \\
\hline Pull back in hole with top drive to 1462.9 mbsf. & 1930 & 24 May & 0.50 & 0.02 & 903.50 & 37.65 & \\
\hline Rack top drive. & 2000 & 24 May & 0.50 & 0.02 & 904.00 & 37.67 & \\
\hline Pull back in hole with drill string to $53.2 \mathrm{mbsf}$. & 2030 & 24 May & 3.50 & 0.15 & 907.50 & 37.81 & \\
\hline Repair and replace damaged cam roller on DES. & 000 & 25 May & 1.00 & 0.04 & 908.50 & 37.85 & \\
\hline Resume POOH from $53.2 \mathrm{mbsf}$ and clear seafloor at $0100 \mathrm{~h}$. & 100 & 25 May & 6.00 & 0.25 & 914.50 & 38.10 & Clear seafloor at $0100 \mathrm{~h}$. \\
\hline $\begin{array}{l}\text { Disassemble and empty RCJB of } 4 \text { small cobbles. Empty } 3 \text { EXJBs and } \\
\text { clean out the usual assortment of cuttings, etc. }\end{array}$ & 700 & 25 May & 1.25 & 0.05 & 915.75 & 38.16 & End Run 21 at 0700 h. Samples Run21-RCJB, BSJB, EXJB. \\
\hline Make up Bowen fishing magnet and 3 EXJB; RIH to 109.5 mbrf. & 815 & 25 May & 1.25 & 0.05 & 917.00 & 38.21 & Start Run 22: fishing magnet plus $3 \mathrm{EXJB}$. \\
\hline Service rig. & 930 & 25 May & 0.50 & 0.02 & 917.50 & 38.23 & \\
\hline Resume RIH 109.5-2612 mbrf. & 1000 & 25 May & 4.50 & 0.19 & 922.00 & 38.42 & \\
\hline Install VIT. & 1430 & 25 May & 0.50 & 0.02 & 922.50 & 38.44 & \\
\hline Continue RIH 2612-3632 mbrf. & 1500 & 25 May & 1.50 & 0.06 & 924.00 & 38.50 & \\
\hline
\end{tabular}




\begin{tabular}{|c|c|c|c|c|c|c|c|}
\hline \multirow[b]{3}{*}{ Operation } & \multicolumn{2}{|c|}{ Start } & \multicolumn{4}{|c|}{ Expedition (from departure time) } & \multirow[b]{3}{*}{ Comments } \\
\hline & \multirow{2}{*}{$\begin{array}{l}\text { Local } \\
\text { time }(h)\end{array}$} & \multirow{2}{*}{$\begin{array}{l}\text { Date } \\
(2011)\end{array}$} & \multicolumn{2}{|c|}{ Duration } & \multicolumn{2}{|c|}{ Time (cumulative) } & \\
\hline & & & $\mathrm{h}$ & day & $\mathrm{h}$ & day & \\
\hline Search and position vessel. Reenter Hole 1245D at 1645 h (Reentry 22). & 1630 & 25 May & 0.25 & 0.01 & 924.25 & 38.51 & Reentry 22. \\
\hline RIH to 427.1 mbsf. & 1645 & 25 May & 1.25 & 0.05 & 925.50 & 38.56 & \\
\hline Recover VIT. & 1800 & 25 May & 0.50 & 0.02 & 926.00 & 38.58 & \\
\hline Resume RIH 427.1-1462.6 mbsf. & 1830 & 25 May & 2.50 & 0.10 & 928.50 & 38.69 & \\
\hline Pick up top drive. & 2100 & 25 May & 0.50 & 0.02 & 929.00 & 38.71 & \\
\hline RIH with top drive; tag fill at 1519.0 mbsf. & 2130 & 25 May & 0.50 & 0.02 & 929.50 & 38.73 & \\
\hline Wash to 1520.0 mbsf. Work fishing magnet and junk baskets. & 2200 & 25 May & 0.50 & 0.02 & 930.00 & 38.75 & \\
\hline Displace lower annulus with $200 \mathrm{bbl}$ of drill water. & 2230 & 25 May & 0.50 & 0.02 & 930.50 & 38.77 & \\
\hline Pull back with top drive to 1433.8 mbsf. & 2300 & 25 May & 0.75 & 0.03 & 931.25 & 38.80 & \\
\hline Rack top drive. & 2345 & 25 May & 0.50 & 0.02 & 931.75 & 38.82 & \\
\hline $\mathrm{POOH}$ with drill string and clear seafloor at $0230 \mathrm{~h}$. & 015 & 26 May & 7.75 & 0.32 & 939.50 & 39.15 & Clear seafloor at $0230 \mathrm{~h}$. \\
\hline $\begin{array}{l}\text { Disassemble and empty EXJBs. Fishing magnet contained very little } \\
\text { metal debris all of which was finely ground?! }\end{array}$ & 800 & 26 May & 1.00 & 0.04 & 940.50 & 39.19 & End Run 22 at 0800 h. Samples Run22-FM, BSJB, EXJB. \\
\hline Make up and deploy logging bit and DC and deploy same to $2923 \mathrm{mbrf}$. & 900 & 26 May & 6.50 & 0.27 & 947.00 & 39.46 & Start Run 23: downhole measurements (logging bit). \\
\hline Deploy VIT. & 1530 & 26 May & 0.50 & 0.02 & 947.50 & 39.48 & \\
\hline RIH drill string to 3638 mbrf. & 1600 & 26 May & 1.25 & 0.05 & 948.75 & 39.53 & \\
\hline Search and position vessel. Reenter Hole $1256 \mathrm{D}$ at $1725 \mathrm{~h}$. & 1715 & 26 May & 0.25 & 0.01 & 949.00 & 39.54 & Reentry 23. \\
\hline $\begin{array}{l}\text { RIH drill string to } 203.3 \text { mbsf. Pick up } 2 \text { knobbies and set EOP at } 218.9 \\
\text { mbsf. }\end{array}$ & 1730 & 26 May & 1.25 & 0.05 & 950.25 & 39.59 & \\
\hline Recover VIT. & 1845 & 26 May & 1.25 & 0.05 & 951.50 & 39.65 & \\
\hline Rig up for logging. & 2000 & 26 May & 0.50 & 0.02 & 952.00 & 39.67 & \\
\hline Make up Log 1 (triple combo: GR/APS/HLDS/HRLA/GPIT) & 2030 & 26 May & 2.50 & 0.10 & 954.50 & 39.77 & \\
\hline $\begin{array}{l}\text { Deploy Log } 1 \text { into the pipe at } 2255 \mathrm{~h} \text {. Reached the bottom of the hole at } \\
1520.0 \text { mbsf. Recover tool at } 0700 \mathrm{~h} \text {. }\end{array}$ & 2300 & 26 May & 8.00 & 0.33 & 962.50 & 40.10 & \\
\hline $\begin{array}{l}\text { Disassemble triple combo. Make up second log (FMS-sonic). Deploy } \\
\text { FMS-sonic into the pipe at } 1050 \mathrm{~h} \text {. }\end{array}$ & 700 & 27 May & 4.00 & 0.17 & 966.50 & 40.27 & \\
\hline Tool unable to exit pipe into hole. Recover FMS-sonic at $1410 \mathrm{~h}$. & 1100 & 27 May & 3.25 & 0.14 & 969.75 & 40.41 & \\
\hline $\begin{array}{l}\text { Replace damaged lower centralizer spring and redeploy FMS-sonic at } \\
1500 \mathrm{~h} \text {. }\end{array}$ & 1415 & 27 May & 0.75 & 0.03 & 970.50 & 40.44 & \\
\hline $\begin{array}{l}\text { RIH FMS-sonic. Tool appears to jam inside BHA with lower section ( } 20 \\
\text { m) of unit extending } 20 \mathrm{~m} \text { into open hole. }\end{array}$ & 1500 & 27 May & 1.50 & 0.06 & 972.00 & 40.50 & FMS-sonic string jammed in logging bit. \\
\hline Attempt to pump tool clear without success. & 1630 & 27 May & 1.75 & 0.07 & 973.75 & 40.57 & \\
\hline Make up Kinley cutter assemblies. Drop crimper into pipe at $2135 \mathrm{~h}$. & 1815 & 27 May & 4.50 & 0.19 & 978.25 & 40.76 & \\
\hline Drop hammer into pipe at $2245 \mathrm{~h}$. & 2245 & 27 May & 0.50 & 0.02 & 978.75 & 40.78 & \\
\hline Assemble Kinley severing tool and drop into pipe. & 2315 & 27 May & 2.00 & 0.08 & 980.75 & 40.86 & \\
\hline Drop hammer and server logging cable. & 115 & 28 May & 0.50 & 0.02 & 981.25 & 40.89 & \\
\hline Recover and tie back logging cable. & 145 & 28 May & 1.75 & 0.07 & 983.00 & 40.96 & \\
\hline $\mathrm{POOH}$ with drill string to $19 \mathrm{mbrf}$. Clear seafloor at $0425 \mathrm{~h}$. & 330 & 28 May & 6.00 & 0.25 & 989.00 & 41.21 & Clear seafloor at $0425 \mathrm{~h}$. \\
\hline $\begin{array}{l}\text { Release jammed FMS-sonic tool from landing saver sub in BHA. Tool is in } \\
\text { good condition. }\end{array}$ & 930 & 28 May & 2.50 & 0.10 & 991.50 & 41.31 & End Run 23 at 0930 h. No FMS-sonic, no UBI. \\
\hline $\begin{array}{l}\text { Make up RCB 3-stand BHA with new RCB C-9 bit. Check core barrel } \\
\text { space out and RIH to } 134 \text { mbrf. }\end{array}$ & 1200 & 28 May & 2.00 & 0.08 & 993.50 & 41.40 & Start Run 24: Ulterra RCB-9 bit for coring and then cementing. \\
\hline Slip and cut $115 \mathrm{ft}$ of drilling line (eight of expedition). & 1400 & 28 May & 1.50 & 0.06 & 995.00 & 41.46 & \\
\hline RIH drill string to $2695 \mathrm{mbrf}$. & 1530 & 28 May & 5.00 & 0.21 & 1000.00 & 41.67 & \\
\hline Launch VIT. & 2030 & 28 May & 0.50 & 0.02 & 1000.50 & 41.69 & \\
\hline RIH drill string to 3638 mbrf. & 2100 & 28 May & 1.25 & 0.05 & 1001.75 & 41.74 & \\
\hline Search and position vessel. Reenter Hole 1256D at 2225 h (Reentry 24). & 2215 & 28 May & 0.25 & 0.01 & 1002.00 & 41.75 & Reentry 24. \\
\hline RIH drill string to 1430.5 mbsf. & 2230 & 28 May & 2.75 & 0.11 & 1004.75 & 41.86 & \\
\hline Recover VIT and coat line on the way out. & 115 & 29 May & 0.75 & 0.03 & 1005.50 & 41.90 & \\
\hline Pick up top drive and obtain SCR parameters. & 200 & 29 May & 0.50 & 0.02 & 1006.00 & 41.92 & \\
\hline
\end{tabular}




\begin{tabular}{|c|c|c|c|c|c|c|c|}
\hline \multirow[b]{3}{*}{ Operation } & \multicolumn{2}{|c|}{ Start } & \multicolumn{4}{|c|}{ Expedition (from departure time) } & \multirow[b]{3}{*}{ Comments } \\
\hline & \multirow{2}{*}{$\begin{array}{l}\text { Local } \\
\text { time }(h)\end{array}$} & \multirow{2}{*}{$\begin{array}{l}\text { Date } \\
(2011)\end{array}$} & \multicolumn{2}{|c|}{ Duration } & \multicolumn{2}{|c|}{ Time (cumulative) } & \\
\hline & & & $\mathrm{h}$ & day & $\mathrm{h}$ & day & \\
\hline RIH top drive $1430.5-1520.2$ mbsf. & 230 & 29 May & 1.50 & 0.06 & 1007.50 & 41.98 & \\
\hline Circulate $100 \mathrm{bbl}$ sweep at $1520.0 \mathrm{mbsf}$. & 400 & 29 May & 1.25 & 0.05 & 1008.75 & 42.03 & \\
\hline $\begin{array}{l}\text { Drop fresh core barrel and rotary core } 239 \mathrm{R}(1520.2-1521.6 \mathrm{mbsf}) \text { at } \\
\text { average ROP }=0.6 \mathrm{~m} / \mathrm{h} \text {. Average recovery }=36 \% \text {. No indication of } \\
\text { metal in the core barrel. No symptoms of downhole junk in the coring } \\
\text { process. Time for coring expires. Prepare for cementing. Circulate } 50 \\
\text { bbl sweep at } 1521.6 \mathrm{mbsf} \text {. }\end{array}$ & 515 & 29 May & 5.00 & 0.21 & 1013.75 & 42.24 & Core $239 \mathrm{R}$. \\
\hline RIH coring line to $1510.6 \mathrm{mbsf}$ and coat same on retrieval. & 1015 & 29 May & 1.75 & 0.07 & 1015.50 & 42.31 & \\
\hline Rack sinker bars and dress for layup period. & 1200 & 29 May & 0.25 & 0.01 & 1015.75 & 42.32 & \\
\hline Pull back in hole with top drive to 1487.8 mbsf. Rack top drive. & 1215 & 29 May & 1.00 & 0.04 & 1016.75 & 42.36 & \\
\hline $\begin{array}{l}\text { Make up circulating head and pressure test same. Position bit at } 1518.6 \\
\text { mbsf. }\end{array}$ & 1315 & 29 May & 0.50 & 0.02 & 1017.25 & 42.39 & \\
\hline Mix and pump $15 \mathrm{bbl}$ of 15 ppg cement. & 1345 & 29 May & 0.50 & 0.02 & 1017.75 & 42.41 & Cement plug 1 (BOH). \\
\hline Displace cement with seawater. & 1415 & 29 May & 0.50 & 0.02 & 1018.25 & 42.43 & \\
\hline Lay out circulating head and pull back in hole to $1372.6 \mathrm{mbsf}$. & 1445 & 29 May & 0.50 & 0.02 & 1018.75 & 42.45 & \\
\hline Flush drill string with seawater ( $2 \times$ annular volumes). & 1515 & 29 May & 1.00 & 0.04 & 1019.75 & 42.49 & \\
\hline Pull back with drill string to 940.8 mbsf. & 1615 & 29 May & 1.00 & 0.04 & 1020.75 & 42.53 & \\
\hline Mix and pump $58 \mathrm{bbl}$ of $15 \mathrm{ppg}$ cement slurry. & 1715 & 29 May & 1.00 & 0.04 & 1021.75 & 42.57 & Cement plug 2 (910-940 mbsf). \\
\hline Displace cement with seawater. & 1815 & 29 May & 0.50 & 0.02 & 1022.25 & 42.59 & \\
\hline Pull back with drill string to $739.3 \mathrm{mbsf}$. & 1845 & 29 May & 0.75 & 0.03 & 1023.00 & 42.63 & \\
\hline Flush drill string seawater ( $2 \times$ annular volumes). & 1930 & 29 May & 0.50 & 0.02 & 1023.50 & 42.65 & \\
\hline $\begin{array}{l}\text { POOH with drill string. Clear top of cone at } 2135 \text { h. Disassemble BHA } \\
\text { and stow DC in forward tubular racks. }\end{array}$ & 2000 & 29 May & 12.00 & 0.50 & 1035.50 & 43.15 & Clear seafloor at 2135 h. End Run 24. \\
\hline Recover beacons and secure vessel for sea. & 800 & 30 May & 3.50 & 0.15 & 1039.00 & 43.29 & \\
\hline Under way to Balboa, Panama. Advance clock $1 \mathrm{~h}$ on 31 May (1200 h). & 1130 & 30 May & 91.50 & 3.81 & 1130.50 & 47.10 & End of Expedition 335. \\
\hline
\end{tabular}

Table based on R. Grout (Operations Superintendent) daily operations reports. Time breakdown is by nearest $0.25 \mathrm{~h} . \mathrm{BHA}=$ bottom-hole assembly, MBR $=$ mechanical bit release, $\mathrm{VIT}=$ vibra-

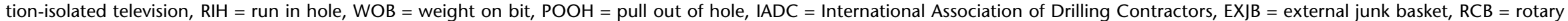
core barrel, RIS = Rig Instrumentation System, $\mathrm{ROP}=$ rate of penetration, $\mathrm{TCl}=$ tungsten carbide inserts, $\mathrm{DC}=$ drill collar, $\mathrm{DP}=$ drill pipe, $\mathrm{SCR}=$ slow circulating rate, $\mathrm{RC}$ (B $=$ reverse circulation

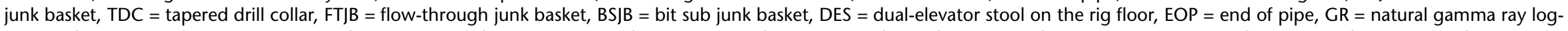
ging tool, APS = Accelerator Porosity Sonde, HLDS = Hostile Environment Litho-Density Sonde, HRLA = High-Resolution Laterolog Array, GPIT = General Purpose Inclinometry Tool, FMS-sonic = Formation MicroScanner sonic, UBI = Ultrasonic Borehole Imager, BOH = bottom of hole. This table is available in ASCII and in Microsoft Excel format (see 101_T03.XLS in CHAPTER_101 in TABLES in "Supplementary material"). 
Table T4. Expedition 335 coring summary.

\begin{tabular}{|c|c|c|c|c|c|c|c|c|c|c|c|}
\hline Core & $\begin{array}{l}\text { Top depth } \\
\text { drilled } \\
\text { DSF (m) }\end{array}$ & $\begin{array}{c}\text { Bottom } \\
\text { depth drilled } \\
\text { DSF }(m)\end{array}$ & $\begin{array}{l}\text { Advanced } \\
(\mathrm{m})\end{array}$ & $\begin{array}{l}\text { Recovered } \\
\text { length }(\mathrm{m})\end{array}$ & $\begin{array}{c}\text { Curated } \\
\text { length }(m)\end{array}$ & $\begin{array}{l}\text { Top depth } \\
\text { cored } \\
\text { CSF }(m)\end{array}$ & $\begin{array}{l}\text { Bottom } \\
\text { depth } \\
\text { recovered } \\
\text { (m) }\end{array}$ & $\begin{array}{c}\text { Recovery } \\
\text { (\%) }\end{array}$ & $\begin{array}{c}\text { Date } \\
(2011)\end{array}$ & $\begin{array}{l}\text { Local time } \\
\text { (h) }\end{array}$ & $\begin{array}{l}\text { Numbers } \\
\text { of sections }\end{array}$ \\
\hline \multicolumn{12}{|l|}{ 335-U1256D- } \\
\hline $1 \mathrm{G}$ & 924.0 & 932.9 & 8.9 & 0.12 & 0.12 & 924.0 & 924.12 & 1 & 3 May & 2120 & 1 \\
\hline $2 \mathrm{G}$ & 932.9 & 942.5 & 9.6 & 0.17 & 0.17 & 932.9 & 933.07 & 2 & 3 May & 2345 & 1 \\
\hline $3 G$ & 942.5 & 952.1 & 9.6 & 0.08 & 0.08 & 942.5 & 942.58 & 1 & 4 May & 0150 & 1 \\
\hline $4 \mathrm{G}$ & 952.1 & 961.7 & 9.6 & 0.05 & 0.05 & 952.1 & 952.15 & 1 & 4 May & 0350 & 1 \\
\hline $5 G$ & 961.7 & 971.3 & 9.6 & 0.03 & 0.03 & 961.7 & 961.73 & 0 & 4 May & 0545 & 1 \\
\hline $6 \mathrm{G}$ & 971.3 & 980.9 & 9.6 & 0.00 & 0.00 & 971.3 & 971.30 & 0 & 4 May & 1315 & 0 \\
\hline $7 W$ & 980.9 & 1507.1 & 526.2 & 0.00 & 0.00 & 980.9 & 980.90 & 0 & 5 May & 0100 & 1 \\
\hline $235 \mathrm{R}$ & 1507.1 & 1511.8 & 4.7 & 0.33 & 0.36 & 1507.1 & 1507.47 & 7 & 5 May & 0815 & 1 \\
\hline $236 \mathrm{R}$ & 1511.8 & 1516.5 & 4.7 & 0.61 & 0.63 & 1511.8 & 1512.43 & 13 & 5 May & 1320 & 1 \\
\hline $237 R$ & 1516.5 & 1518.2 & 1.7 & 0.00 & 0.00 & 1516.5 & 1516.50 & 0 & 5 May & 2135 & 0 \\
\hline $238 \mathrm{R}$ & 1518.2 & 1520.2 & 2.0 & 0.20 & 0.20 & 1518.2 & 1518.00 & 10 & 6 May & 1330 & 1 \\
\hline $239 R$ & 1520.2 & 1521.6 & 1.4 & 0.50 & 0.53 & 1520.2 & 1520.73 & 36 & 29 May & 1015 & 1 \\
\hline \multicolumn{3}{|l|}{ Totals: } & 597.6 & 2.09 & 2.18 & & & & & & 10 \\
\hline
\end{tabular}

This table is available in ASCII and in Microsoft Excel format (see 101_T04.XLS in CHAPTER_101 in TABLES in "Supplementary material"). 
Location: $6^{\circ} 44.163^{\prime} \mathrm{N}, 91^{\circ} 56.061^{\prime} \mathrm{W}$

Water depth $(\mathrm{m}): 3634.7 ; 3645.4 \mathrm{mbrf}$

Sediment thickness (m): 250

Interval in Hole 1256C drilled during Leg 206: 338.5 mbsf, 88.5 msb

Casing in Hole 1256D:

Height of reentry cone: $2.4 \mathrm{~m}$

Internal diameter of reentry cone: $3.5 \mathrm{~m} \mathrm{(11} \mathrm{ft,} 5$ inches)

20 inch casing string $(\mathrm{m}): 95.12$

16 inch casing string $(\mathrm{m}) 269$

Interval in Hole 1256D drilled during

Leg 206: 752 mbsf, 502 msb; basement advance (m): 502

Expedition 309: $1255.1 \mathrm{mbsf}, 1005.1 \mathrm{msb}$; basement advance $(\mathrm{m}): 503$

Expedition 312: $1507.1 \mathrm{mbsf}, 1257.1 \mathrm{msb}$; basement advance $(\mathrm{m}): 252$

Expedition 335: $1521.6 \mathrm{mbsf}, 1271.6 \mathrm{msb}$; basement advance $(\mathrm{m}): 14.5$

\begin{tabular}{|c|c|c|c|c|c|}
\hline $\begin{array}{c}\text { Major } \\
\text { lithologic zone }\end{array}$ & Sublithology & Top of lithology & Top igneous unit & $\begin{array}{l}\text { Depth } \\
\text { (mbsf) }\end{array}$ & Criteria \\
\hline \multirow[t]{3}{*}{ Lavas } & Lava pond & 206-1256D-2R-1, $0 \mathrm{~cm}$ & $\begin{array}{l}1256 \mathrm{D}-1 \\
(1256 \mathrm{C}-1 \text { through } \\
1256 \mathrm{C}-18)\end{array}$ & $\sim 250$ & Massive ponded lava including overlying sheet flows. \\
\hline & Inflated flows & 206-1256D-13R-1, $0 \mathrm{~cm}$ & $1256 \mathrm{D}-2$ & 350.3 & Massive, sheet, and pillowed flows with rare inflation features. \\
\hline & Sheet and massive flows & 206-1256D-43R-1, $0 \mathrm{~cm}$ & 1256D-16 & 533.9 & Sheet flows with subordinate massive flows. \\
\hline Transition zone & & $309-1256 \mathrm{D}-117 \mathrm{R}-1,85 \mathrm{~cm}$ & $1256 \mathrm{D}-40$ & 1004.2 & Sheet flows with breccia, rare dikes, and alteration at (sub)greenschist facies conditions. \\
\hline \multirow[t]{2}{*}{ Sheeted dike complex } & Upper dikes & 309-1256D-129R-1, $0 \mathrm{~cm}$ & 1256D-44A & 1060.9 & $\begin{array}{l}\text { Massive basalt, common subvertical intrusive contacts. Elevated } P \text {-wave velocity and } \\
\text { thermal conductivity. }\end{array}$ \\
\hline & Granoblastic dikes & 312-1256D-192R-1, $0 \mathrm{~cm}$ & 1256D-78 & 1348.3 & $\begin{array}{l}\text { Granoblastic texture; equant grains; secondary clinopyroxene, orthopyroxene, } \\
\text { plagioclase, hornblende, magnetite, and ilmenite. }\end{array}$ \\
\hline \multirow[t]{4}{*}{ Plutonic section } & Gabbro 1 & 312-1256D-213R-1, $52 \mathrm{~cm}$ (Piece 13) & $1256 \mathrm{D}-81$ & 1406.62 & $\begin{array}{l}\text { Medium-grained, generally orthopyroxene-bearing gabbroic rocks intrude overlying } \\
\text { dikes: olivine gabbro, gabbro, and (disseminated) oxide gabbro, intruded by oxide } \\
\text { gabbro to oxide quartz diorite. }\end{array}$ \\
\hline & Dike Screen 1 & 312-1256D-225R-1, 0 cm (Piece 1) & $1256 \mathrm{D}-90$ & 1458.9 & $\begin{array}{l}\text { Fine-grained to cryptocrystalline basalt dikes. Highly altered; granoblastic texture; } \\
\text { secondary clinopyroxene, orthopyroxene, plagioclase, magnetite, ilmenite, and } \\
\text { hornblende. }\end{array}$ \\
\hline & Gabbro 2 & 312-1256D-230R-1, $15 \mathrm{~cm}$ (Piece 5) & $1256 \mathrm{D}-91$ & 1483.1 & $\begin{array}{l}\text { Plutonic rock intrudes dike screen; medium-grained disseminated oxide gabbronorite with } \\
\text { subordinate oxide gabbro, intruded by oxide gabbro, (oxide) diorite, and oxide quartz } \\
\text { diorite veins; all highly altered; stoped basalt. }\end{array}$ \\
\hline & Dike Screen 2 & 312-1256D-232R-2, $98 \mathrm{~cm}$ (Piece 9) & $1256 \mathrm{D}-94$ & 1494.9 & $\begin{array}{l}\text { Fine-grained granoblastic basalt (Unit 1256D-94) may have igneous or metamorphic } \\
\text { origin. Unrecrystallized greenschist-facies late dike (Unit 1256D-95) at } 1502.6 \text { mbsf. } \\
\text { Strongly to completely recrystallized granoblastic basalts containing minor oxide diorite } \\
\text { patches; subordinate quartz diorite and tonalite (Unit 1256D-96). Also includes } \\
\text { granoblastic basalts intruded by oxide gabbro to tonalite patches, veins, and dikelets } \\
\text { and with minor }(<3 \%) \text { gabbroic rocks, from the "junkyards" at } \sim 1500-1521.6 \text { mbsf. }\end{array}$ \\
\hline
\end{tabular}

This table is available in ASCII and in Microsoft Excel format (see 101_T05.XLS in CHAPTER_101 in TABLES in "Supplementary material"). 
Table T6. Junk basket sample summary, Hole 1256D, Expedition 335. (Continued on next page.)

\begin{tabular}{|c|c|c|c|c|c|c|}
\hline $\begin{array}{l}\text { Date } \\
(2011)\end{array}$ & $\begin{array}{c}\text { Local } \\
\text { time } \\
\text { (h) }\end{array}$ & $\begin{array}{c}\text { Top } \\
\text { depth } \\
\text { (mbsf) }\end{array}$ & $\begin{array}{l}\text { Bottom } \\
\text { depth } \\
\text { (mbsf) }\end{array}$ & $\begin{array}{l}\text { Volume } \\
\left(\mathrm{cm}^{3}\right)\end{array}$ & Sample & Comments \\
\hline $23 \mathrm{Apr}$ & 0600 & 0 & 923 & 3000 & Run02-EXJB & Basaltic cuttings ( 2 bags; fine gravel to rounded pebbles) \\
\hline $28 \mathrm{Apr}$ & 0715 & 0 & 923 & 700 & Run06-EXJB & Cuttings and rock pieces ( 1 bag + series of pebbles) \\
\hline 8 May & 0715 & 0 & 1434 & 1500 & Run10-DC & Fine cuttings from bit sub in BHA \\
\hline 8 May & 0715 & 0 & 1434 & 2000 & Run10-EXJB & Fine cuttings \\
\hline 8 May & 0715 & 0 & 1434 & 100 & Run10-EXJB & Rock pieces \\
\hline 8 May & 0715 & 0 & 1434 & 1500 & Run10-FM & Fine metal + rock cuttings from fishing magnet \\
\hline 8 May & 0715 & 0 & 1434 & 100 & Run10-FM & Mud from fishing magnet \\
\hline 10 May & 1130 & 1353 & 1520 & 5000 & Run11-EXJB & $\begin{array}{l}\text { Fine cuttings to large pieces of rock, mostly granoblastic basalt (multiple bags; various grain size), some gabbro ( } 1 \text { bag of rock } \\
\text { chips) }\end{array}$ \\
\hline 11 May & 2130 & 1328 & 1518 & 5000 & Run12-DC & Rock material (fine cuttings) from BHA \\
\hline 11 May & 2130 & 1328 & 1518 & & Run12-EXJB & Fine cuttings and pebbles ( 2 bags granoblastic; 1 small bag gabbro) \\
\hline 11 May & 2130 & 1516 & 1518 & 5000 & Run12-RCJB & Fine cuttings and pebbles (multiple bags) and large cobbles (see list below) \\
\hline 11 May & 2130 & 1516 & 1518 & 1512 & Run12-RCJB-Rock A & Cobble (granoblastic) \\
\hline 11 May & 2130 & 1516 & 1518 & 1058 & Run12-RCJB-Rock B & Cobble (granoblastic) \\
\hline 11 May & 2130 & 1516 & 1518 & 454 & Run12-RCJB-Rock C & Cobble (granoblastic) \\
\hline 11 May & 2130 & 1516 & 1518 & 302 & Run12-RCJB-Rock D & Cobble (granoblastic) \\
\hline 11 May & 2130 & 1516 & 1518 & 151 & Run12-RCJB-Rock E & Cobble (granoblastic) \\
\hline 11 May & 2130 & 1516 & 1518 & & Run12-RCJB-Rock F & Cobble (granoblastic) \\
\hline 11 May & 2130 & 1516 & 1518 & 302 & Run12-RCJB-Rock G & Cobble (granoblastic) \\
\hline 11 May & 2130 & 1516 & 1518 & & Run12-RCJB-Rocks $\mathrm{H}$ to $\mathrm{Y}$ & Cobble (granoblastic) \\
\hline 13 May & 1100 & 270 & 1518 & 5000 & Run13-DC & Large amount of fine-grained cuttings from BHA \\
\hline 13 May & 1100 & 270 & 1518 & 5000 & Run13-EXJB & Fine-grained cuttings \\
\hline 13 May & 1100 & 1516 & 1518 & 2000 & Run13-RCJB & Multiple bags of fine cuttings to pebbles (mostly granoblastic rocks) \\
\hline 13 May & 1100 & 1516 & 1518 & & Run13-RCJB-Rock A & Cobble (granoblastic) \\
\hline 13 May & 1100 & 1516 & 1518 & & Run13-RCJB-Rock B & Cobble (granoblastic) \\
\hline 14 May & 2010 & 1518 & 1520 & 2000 & Run14-BSJB & 3 bags of cuttings (various grain size, fine to gravel) \\
\hline 14 May & 2010 & 1518 & 1520 & 2000 & Run14-EXJB & Multiple bags of cuttings (various grain size, fine to pebbles; some gabbro chips) \\
\hline 14 May & 2010 & 1518 & 1520 & & Run14-FTJB-Rock A & Cobble (granoblastic) \\
\hline 14 May & 2010 & 1518 & 1520 & & Run14-FTJB-Rock B & Cobble (granoblastic) \\
\hline 16 May & 1545 & 1518 & 1520 & 5000 & Run15-EXJB & Multiple bags of cuttings (various grain size, fine to pebbles; granoblastic) \\
\hline 19 May & 0315 & 1520 & 1521 & 2000 & Run17-BSJB & 7 bags of cuttings (various grain size, gravel to pebbles; granoblastic) \\
\hline 21 May & 1230 & 1518 & 1521 & 5000 & Run18-BSJB & 4 bags of cuttings (various grain size, fine to pebbles; granoblastic); 2 small bags of leucocratic gravel \\
\hline 22 May & 1645 & 1510 & 1520 & 5000 & Run19-BSJB & 2 bags of fine-grained cuttings \\
\hline 22 May & 1645 & 1510 & 1520 & 300 & Run19-EXJB1 & Pebbles of basalt and granoblastic rocks, gravel \\
\hline 22 May & 1645 & 1510 & 1520 & 100 & Run19-EXJB2 & Pebbles of basalt and granoblastic rocks, gravel \\
\hline 22 May & 1645 & 1518 & 1521 & 50 & Run19-RCJB & Pebbles (granoblastic + 1 gabbro) \\
\hline 22 May & 1645 & 1518 & 1521 & & Run19-RCJB-Rock A & Cobble (granoblastic with diorite vein) \\
\hline 22 May & 1645 & 1518 & 1521 & & Run19-RCJB-Rock B & Cobble (granoblastic) \\
\hline 22 May & 1645 & 1518 & 1521 & & Run19-RCJB-Rock C & Cobble (granoblastic) \\
\hline 22 May & 1645 & 1518 & 1521 & & Run19-RCJB-Rock D & Cobble (granoblastic) \\
\hline 24 May & 0215 & 1510 & 1520 & 5000 & Run20-BSJB & 2 bags (fine to gravel-sized cuttings); 1 small bag of pebbles \\
\hline 24 May & 0215 & 1510 & 1520 & 5000 & Run20-EXJB1 & 4 bags of cuttings (various grain size, fine to pebbles; granoblastic) \\
\hline 24 May & 0215 & 1510 & 1520 & 3000 & Run20-EXJB2 & 1 bag of granoblastic pebbles; 1 bag of leucocratic pebbles \\
\hline 24 May & 0215 & 1518 & 1521 & 500 & Run20-RCJB & Large cobbles (see list below) \\
\hline 24 May & 0215 & 1519 & 1519.5 & & Run20-RCJB-Rock A & Cobble (granoblastic) \\
\hline 24 May & 0215 & 1519 & 1519.5 & & Run20-RCJB-Rock B & Cobble (granoblastic) \\
\hline 24 May & 0215 & 1519 & 1519.5 & & Run20-RCJB-Rock C & Cobble (gabbro) \\
\hline 24 May & 0215 & 1519 & 1519.5 & & Run20-RCJB-Rock D & Pebble (leucocratic material) \\
\hline 24 May & 0215 & 1519 & 1519.5 & & Run20-RCJB-Rock E & Pebble (leucocratic material) \\
\hline 25 May & 0700 & 1510 & 1520 & 2000 & Run21-BSJB & 3 bags of cuttings (various grain size, fine to gravel) \\
\hline
\end{tabular}


Table T6 (continued).

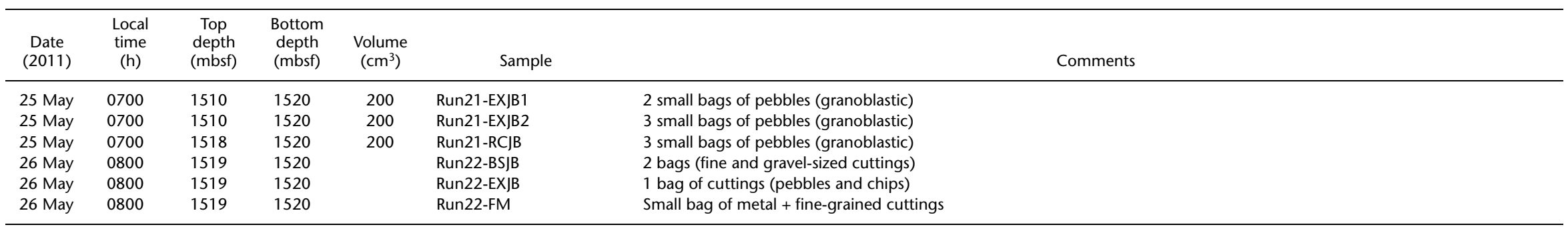

$\mathrm{EX} \mid \mathrm{B}=$ external junk basket, $\mathrm{DC}=$ drill collar, $\mathrm{BHA}=$ bottom hole assembly, $\mathrm{FM}=$ fishing magnet, $\mathrm{RC} \mid \mathrm{B}=$ reverse circulating junk basket, $\mathrm{BS} \mid \mathrm{B}=$ bit sub junk basket, $\mathrm{FT} \mid \mathrm{B}=$ flow through junk basket. This table is available in ASCII and in Microsoft Excel format (see 101_T06.XLS in CHAPTER_101 in TABLES in "Supplementary material"). 
Table T7. Major operational phases during Expedition 335.

\begin{tabular}{clcr}
\hline Phase & \multicolumn{1}{c}{ Operations } & Days & Reentries \\
\hline 1 & 920 mbsf: open and cement to stabilize hole (920-960 mbsf) & 15.00 & 9 \\
2 & Core (4 cores; 8\% recovery) & $\sim 2$ & 1 \\
3 & Fish/mill junk and ream/clean hole & 19 & 13 \\
4 & Logging & $\sim 2$ & 1 \\
5 & Core (1 core; 35\% recovery), cement to stabilize hole (BOH to 1510 mbsf, 940-910 mbsf) & $\sim 1.5$ & 1 \\
\hline
\end{tabular}

$\mathrm{BOH}=$ bottom of hole. 24 reentries and $\sim 150$ miles $(\sim 240 \mathrm{~km})$ of pipe trip. $920-940$ mbsf zone: stabilized (15 trips through after cementing end of Phase 1 without any trouble). Hole: clean and clear of cuttings, no metal junk left at bottom. Cone: clear. "Fieldwork" samples from ocean crust thermal boundary layer.

Table T8. Cement and mud usage during Expedition 335.

\begin{tabular}{lcc}
\hline & $\begin{array}{c}\text { Onboard } \\
\text { short tons } \\
\text { (metric T) }\end{array}$ & $\begin{array}{c}\text { Usage } \\
\text { short tons }\end{array}$ \\
\hline Mud & $70(64)$ & 70 \\
$\quad$ Bentonite & $93(84)$ & 49.8 \\
Seawater gel & $111(101)$ & 119.8 \\
Total mud used to flush cuttings & $142(129)$ & 46.3 \\
Barite & & 46.2 \\
Cement & & \\
\hline
\end{tabular}

